\author{
В.Т. Старожилов
}

\title{
ЛАНДШАФТНАЯ ГЕОГРАФИЯ ПРИМОРСКОГО КРАЯ ТИХООКЕАНСКОЙ РОССИИ
}

\author{
Курс лекций \\ В трех частях
}

Часть 1.

Регионально-компонентная специфика и пространственный анализ геосистем 
Предисловие.........

Научный редактор:

Б.И. Кочуров, доктор географических наук, профессор,

Лекция 1. ВВЕДЕНИЕ

Институт географии РАН, г. Москва

\section{Рецензенты:}

С. М. Говорушко, доктор географических наук, профессор,

Институт географии ДВО РАН, г. Владивосток

А.С. Федоровский, доктор географических наук, профессор,

Дальневосточный федеральный университет, г. Владивосток

\section{Старожилов, В.Т.}

Ландшафтная география Приморского края Тихоокеанской России: курс лекщий. В 3 ч. Ч. 1. Регионально-компонентная специфика и пространственный анализ геосистем / В.Т. Старожилов; [науч. ред. Б. И. Кочуров]. - Владивосток: Дальневост. федерал. ун-т, 2014.- $280 \mathrm{c.}$

ISBN 978-5-7444-3111-2 (ч. 1)

ISBN 978-5-7444-3411-3

На основе углубленного компонентного анализа факторов ландшафтной дифференциации дается региональная классификация, включающая классы, подклассы, роды, виды ландшафтов. Приводятся материалы расчетов площадей структурно-иерархических единиц ландшафтов Приморского края, позволяющие устанавливать параметры ландшафтных изменений и выявить пространственные экологические проблемы. На основе анализа структуры ландшафтов установлен ландшафтный статус территорий регионального горнорудного минерально-сырьевого природопользования. Полученные материалы по ландшафтам впервые для региона предлагается применять как базовую лы по ландшафтам впервые для региона предлагается применять как базовую ваний природной среды, оптимизации природопользования, конструктивного начала в обеспечении экологической безопасности минерально-сырьевого природопользования Приморского края. Они могут служить основой многоцелевых естественнонаучных и прогнозно-экономических исследований, в т.ч. при разработке концепций устойчивого развития регионов.

Для студентов учебных заведений, ученых, производственных специалистов, руководителей органов управления.

Лекция 2. ИСТОРИЯ СТАНОВЛЕНИЯ ЛАНДШАФТНОЙ

ГЕОГРАФИИ ...................................................................... 14

2.1. Становление современного ландшафтоведения ..................... 15

2.2. Ландшафтная география в России и в Приморье ................... 16

Контрольные вопросы.............................................................. 27

Лекция 3. ЛАНДШАФТНЫЙ ПОДХОД В РЕШЕНИИ

ПРИРОДООХРАННО-ЭКОЛОГИЧЕСКИХ ПРОБЛЕМ ............. 28

Контрольные вопросы............................................................ 34

ЛеКцИЯ 4. РЕГИОНАЛЬНАЯ ПРИРОДНО-КОМПОНЕНТНАЯ

СПЕЦИФИКА ПРИМОРЬЯ (фундамент, рельеф) ...................... 36

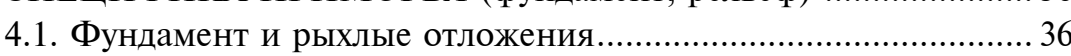

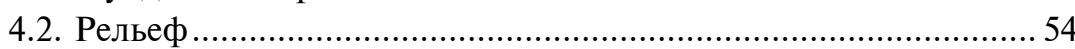

Контрольные вопросы.............................................................. 57

ЛеКцИЯ 5. РЕГИОНАЛЬНАЯ ПРИРОДНО-КОМПОНЕНТНАЯ

СПЕЦИФИКА ПРИМОРЬЯ (кЛИМат) …...................................... 58

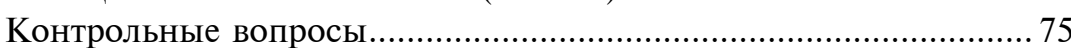

КеКцИЯ 6. РЕГИОНАЛЬНАЯ ПРИРОДНО-КОМПОНЕНТНАЯ

СПЕЦИФИКА ПРИМОРЬЯ (ВОДЫ)

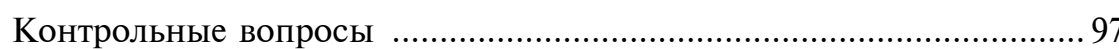

ЛеКцИЯ 7. РЕГИОНАЛЬНАЯ ПРИРОДНО-КОМПОНЕНТНАЯ

СПЕЦИФИКА ПРИМОРЬЯ (почВЫ, растительность) ................ 99

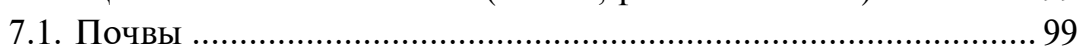

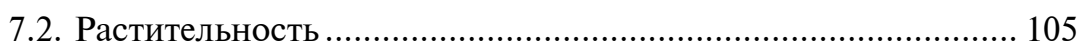

Контрольные вопросы........................................................... 116

ЛеКцИЯ 8. ОРГАНИЗАЦИЯ И ИЕРАРХИЧЕСКАЯ СТРУКТУРА ЛАНДШАФТОВ

8.1. Приморье в системе ландшафтов России (принципы

классификации, картографирование, новые подходы) ....... 117

8.2. Классификация ландшафтов Приморья............................... 122

Контрольные вопросы............................................................ 130

ЛеКцИЯ 9. ОРГАНИЗАЦИЯ И ИЕРАРХИЧЕСКАЯ СТРУКТУРА

ЛАНДШАФТОВ (классы ландшафтов) ................................... 131

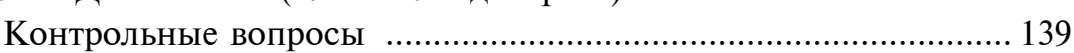


ЛАНДШАФТОВ (видЫ ландшафтов и местности) ....................... 169

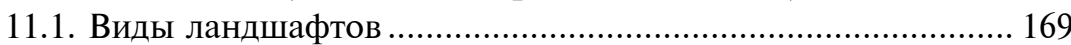

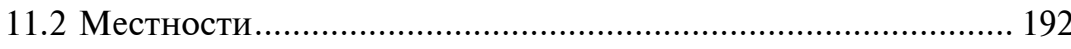

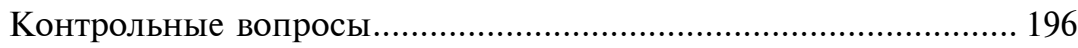

ЛеКция 12. ЛАНДШАФТНЫЙ АНАЛИЗ И СИНТЕЗ КАК ОСНОВА КОМПЛЕКСНОЙ ОЦЕНКИ АНТРОПОГЕННЫХ ПРЕОБРАЗОВАНИЙ ПРИРОДНОЙ СРЕДЫ ПРИМОРЬЯ ..... 197

Контрольные вопросы.......................................................... 218

ЛеКция 13. ЛАНДШАФТНЫЙ АНАЛИЗ И СИНТЕЗ КАК ОСНОВА КОМПЛЕКСНОЙ ОЦЕНКИ АНТРОПОГЕННЫХ ПРЕОБРАЗОВАНИЙ ПРИРОДНОЙ СРЕДЫ ПРИМОРЬЯ ..... 219

Ландшафтный статус промышленных угольных

и горно-рудных центров минерально-сырьевого производства ......

Контрольные вопросы.

ЛеКцИЯ 14. ЛАНДШАФТНЫЙ АНАЛИЗ И СИНТЕЗ КАК ОСНОВА КОМПЛЕКСНОЙ ОЦЕНКИ АНТРОПОГЕННЫХ ПРЕОБРАЗОВАНИЙ ПРИРОДНОЙ СРЕДЫ ПРИМОРЬЯ ..... 227

Контрольные вопросы........................................................ 246

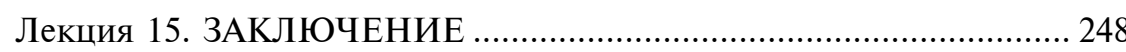

Библиографический список …..................................................... 253

\section{Предисловие}

Представляемый вниманию читателей курс лекций является итогом многолетних авторских научных исследований в сфере геолого-географического изучения и ландшафтного картографирования крупного региона, расположенного в окраинно-континентальном секторе Азиатской части России. Такое расположение района исследований имеет две составляющих: объективную повышенную контрастность и сложность ландшафтной дифференциации, требующую специальных приемов структурно-генетического и функционального методов исследования, построения особой модели организации ландшафтов, и субъективную - отсутствие в регионе ландшафтной школы соответствующего уровня. Ближайший академический Институт географии Сибири и Дальнего Востока (г. Иркутск), как известно, Приморье своими исследованиями почти не охватывал и позже в его названии осталась только Сибирь. Известные российские ландшафтные школы, разрабатывающие представления о полиструктурности геосистем, континуальности и дискретности ландшафтов, детерминированности взаимосвязей между природными компонентами, о ландшафтных границах, ярусности и высотной поясности, дифференциации и интеграции геосистем и т.д. больше ориентировались на свои территории или регионы, а значительная часть Азиатской России, с такими сложными природными явлениями, как мерзлотность, континентальность, секторность оставалась без должного внимания. Именно поэтому автор, утверждая свое право на территориальный ландшафтный анализ и синтез, начал с истории становления ландшафтной географии, места Приморья в системе ландшафтов России, используя ставшие классическими мелкомасштабные карты А.Г. Исаченко и И.С. Гудилина.

Опираясь на теоретические работы, постепенно овладевая достаточно сложным понятийно-терминологическим аппаратом современного ландшафтоведения, В.Т. Старожилов пошел по пути осмысления теории строения ландшафта, оценки природно-компонентной специфики Приморья, включения в систему 
поиска пространственно-временной организации геосистем, выявления регионального и локального уровней упорядоченности ландшафтной структуры. Он доказывает, что ландшафтный синтез, основой которого является морфология ландшафта, служит базой ландшафтного картографирования и подтверждает это детальной характеристикой ландшафтов на уровне родов и видов, ландшафтными схемами и картами. В теоретических построениях автора реализовано взаимодополнение индивидуального (физикогеографическое районирование) и типологического (ландшафтная систематика) подходов: это положения физической географии, разработанные в 60-70-е прошлого века. Это сейчас они представляются обычными, но было время, когда даже сам термин «ландшафтная география» звучал революционно и требовал теоретического обоснования - это сделали Ф.Н. Мильков, А. Г. Исаченко, В.С. Преображенский, А. Басаликас и др.

В теоретических построениях В.Т. Старожилова важное место занимает ландшафтный подход к решению региональных природоохранно-экологических проблем. В уже изданных региональных научных публикациях, а число их достаточно велико, он подчеркивает, что ландшафтный подход в сочетании с объективной оценкой природной среды, среды жизни, открывает новые возможности для оценки условий расселения, хозяйственного освоения и горнорудного природопользования, демографической ёмкости, условий создания системы ООПТ, подхода к ландшафтам как туристско-рекреационному пространству и т.д.

Патриарх советского и российского ландшафтоведения А. Г. Исаченко указывает, что для современного положения этой науки характерно противоречие между небывало резким ухудшением условий его развития и растущим авторитетом за пределами географии. Широко известное высказывание Л.С. Берга «Понять данный ландшафт можно лишь тогда, когда известно, как он произошел и во что со временем превратится» реализовалось в России, как подчеркивает А.Г. Исаченко, лишь частично: примеров исследований, где рассматривалось бы развитие (в определенном временном диапазоне) конкретных ландшафтов либо регионов было не очень много, а сейчас почти нет. В. Т. Старожилов пришел к выводу, что ландшафтный анализ и синтез - явно недостающее звено естественно-научного изучения Дальнего Востока и закрывает этот пробел для Приморья, подготовив почву для эколого-географического анализа территории в фундаментальной трактовке Института географии РАН (А. В. Антипова, Б. И. Ко- чуров). Это важное научное достоинство представляемой монографии, авторский, так будем говорить, вклад в региональную ландшафтную географию.

Научную сторону проделанной работы отражает приведенная в книге специальная таблица, в которой названы проанализированные автором важнейшие направления естественно-научных исследований региона, формирующие теоретическую основу региональной ландшафтной географии, её природный базис и объект изучения - межкомпонентные, комплексные связи. Эта краткая информационно-библиографическая сводка показывает имеющийся в современной науке Приморья спектр региональных исследований: от геологии и экзогенных процессов до ресурсоведения и экологической политики, фиксирует важнейшие научные публикации по этим темам в насыщенном библиографическом списке. Здесь уместен и перечень работ, выполненных автором: он показывает диапазон его научного поиска, отраженный в публикациях, картах, учебных комплексах и пособиях.

В курсе лекций также представлено еще одно углубленно рассмотренное автором научное положение, которое связано с многолетней дискуссионной проблемой ландшафтоведения: о месте и роли каждого компонента в развитии и функционировании природного комплекса, о наличии ведущего фактора развития ландшафтов. Подобные дискуссии идут со времен разработки основ ландшафтоведения Н.А. Солнцевым, А. Г. Исаченко, Ф.Н. Мильковым, В.Б. Сочавой, время от времени возрождаясь и сейчас на фоне отождествления понятий «ландшафт» и «экосистема». Установлено, что зональные, азональные, региональные и локальные закономерности географической дифференциации подчинены действию в первую очередь абиотических факторов: неравномерному распределению солнечной энергии и активной влаги, разнообразию минерального субстрата (литогенной основы в широком смысле этого слова, включая рельеф). Биота может, но не всегда, играть роль ведущего фактора, но даже функционирование геосистемы идет в абиотических рамках. Это важное для теории положение хорошо отражено в представленных материалах курса лекций, в предлагаемой иерархии комплексов, в систематике и структуре ландшафтов. Оно совершенно не противоречит фактору экологизации, а наоборот, приводит к консенсусу в деле решения природоохранных проблем с учетом эволюционно-динамической специфики геосистем, ландшафтного разнообразия, антропогенной трансформации, техногенных нагрузок на лан- 
дшафты, необходимости создания ландшафтно-оценочных карт инновационного назначения.

Заслуживает внимания и достойной оценки углубленная проработка специфики литогенной основы ландшафтов, сделанная на основе многолетних профессиональных изысканий и отражающая палеогеографические, геотектонические литологические, геохимические, гидрогеологические особенности региона, имеющие значение для познания генезиса и современного сложения и устройства ландшафтов Приморья. «Наведение мостов» между всеми естественно-научными дисциплинами, к тому же работающими в различных временных диапазонах, задача сложная, но автор с ней справляется: его классификация вещественно-литологических комплексов, генетических типов отложений, составляющих фундамент ландшафтов, оценка гидрогеологических параметров учтены при выделении подклассов, родов и видов ландшафта.

Итогом многолетних полевых исследований и теоретических обобщений, статистических расчетов, среднемасштабного ландшафтного картографирования региона стала разработка новых, выше упомянутых направлений, которые в совокупности можно рассматривать как научное достижение, вклад в региональную ландшафтную географию. Свидетельством тому выделение и детальное описание 2-х классов, 4-х подклассов, 12-ти родов, 94-х видов и более трех тысяч выделов ландшафтов (последняя цифра может измениться, особенно если на территории будут работать представители какой-нибудь особой ландшафтной школы). Но сделанные на основе уже устоявшихся представлений базовые параметры региональной структуры не подлежат сомнению; подтверждена уникальность сопряжения горных, равнинных, прибрежно-шельфовых и аквально-морских (по Б. В. Преображенскому) геосистем, доказана эффективность ландшафтно-экологического подхода к оценке горнорудного природопользования, опубликованные ландшафтные карты, в легендах которых реализован системно-иерархический подход, используются в проектных работах и практике хозяйствования. Ландшафтные характеристики вошли в информационный фонд и превращаются в учебнометодические пособия. Ликвидировано еще одно «белое пятно» в «ландшафтографии» России. Уместно включение авторских материалов в разрабатываемую Институтом географии Сибири «Ландшафтно-оценочную карту Азиатской части России».

Вместе с тем в работе заложены ростки будущих направлений ландшафтно-экологических исследований. В частности, продук- тивным может быть развитие феноменологических представлений о Сихоте-Алиньском региональном ландшафтном экотоне как сопряженной парагенетической системе природно-территориальных комплексов трех категорий геоэкотонов - климатической (связанной с муссонной компонентой, орографической (мегаантиклинорий) и фиторастительной (суббореальные широколиственные леса). Иерархическое устройство ландшафтного пространства, уже частично отражаемое в ландшафтных картах автора, многоуровневые способы интеграции природных компонентов в геосистемы разного таксономического ранга свидетельствуют, как указывает Э. Г. Коломыц, о полиморфизме гео(эко)систем. Актуальна задача раскрытия механизмов их формирования, саморегуляции и устойчивости на основе изучения вещественно-энергетического и информационного взаимодействия разносубстратных природных компонентов. Заслуживает внимания теоретиков мысль о существовании феномена ландшафтной континентально-океанической дихотомии. В Приморье, переживающем в настоящее время геополитический ренессанс, есть предпосылки усиления вузовской и академической географической науки, в том числе создания ландшафтной школы, здесь необходимы и возможны серьёзные экспериментальные исследования геосистем.

В. И. Булатов, профессор, доктор географических наук 


\section{Лекция 1 \\ ВВЕДЕНИЕ}

Предлагаемый вниманию читателей курс лекций охватывает широкий спектр научных интересов региональной ландшафтной географии, захватывая и природное районирование территории, своеобразие которой обеспечено её палеогеографией, континентально-океанической дихотомией - фундаментальным дуализмом сопряжения суши и моря, парности в организации и функционировании геосистем, единстве и противоположности приморских и континентальных ландшафтов. Исследования в этой области ландшафтоведения, как физико-географической науки, нацелены на разработку природоохранно-экологических основ природопользования. Они интенсивно проводятся в связи с необходимостью обеспечения оптимизации геосистем в условиях интенсификации хозяйственной деятельности и повышенного внимания государства к освоению Приморья и Дальнего Востока.

На основе углубленного компонентного анализа факторов природной дифференциации впервые разработана и предлагается к широкому обсуждению региональная классификация, включающая классы, подклассы, роды, виды ландшафтов. Составленная Ландшафтная карта Приморского края в масштабе 1: 500000 имеет детальную легенду, на её основе выполнены расчеты площадей структурно-иерархических единиц, позволяющие устанавливать параметры ландшафтных изменений и выявить ареалы пространственных экологических проблем. На основе анализа структуры ландшафтов установлен ландшафтный статус территорий регионального горнорудного минерально-сырьевого природопользования. Полученные материалы по ландшафтам впервые для региона предлагается применять как базовую географическую основу оценки экологических проблем и ситуаций. Полученные автором и имеющиеся научные материалы свидетельствуют о существовании в ландшафтном пространстве Дальнего Востока континентально-океанической дихотомии, имеющей глубинные корни и отражаюшейся в ландшафтной дифференциации и организации природной среды.

В курсе лекций отражены следующие теоретические и практические авторские наработки:

1. В фундаменте ландшафтов по петрографическому составу и структурно-тектоническому положению выделено более сорока осадочных, магматических, метаморфических полигенетических комплексов, определяюших базовую, вещественную основу ландшафтов Приморья и флуктуационно-палеогеографические режимы их развития.

2. Выявлены и обоснованы иерархия и структурные варианты распространения ландшафтов Приморского края, отражающие особенности зонально-азональной дифференциации компонентов (фундамента, рельефа, климата, почв, растительности) в связи с иерархической системой, включающей классы, подклассы, роды, виды и местности.

3. Проанализирована специфика природных ландшафтов Приморского края с отражением их пространственно-площадной горизонтальной и высотной дифференциации по территории, представленной в регионе более чем тремя тысячами гетерогенных взаимосвязанных и взаимообусловленных структур.

4. Дана статистическая оценка пространственного распределения современных горных и равнинных ландшафтов и их количественных параметров как основы многоцелевого применения ландшафтного метода.

5. Ландшафтный подход представлен как база комплексного анализа антропогенных преобразований природной среды и конструктивного начала в обеспечении экологической безопасности минерально-сырьевого природопользования Приморского края.

В курсе лекций представлены синтезированные материалы ранее изданных автором карт и объяснительных записок к ним: Карта ландшафтов Приморского края масштаба 1: 500000 [232] и объяснительная записка к ней [233, 234], Карта ландшафтов Приморского края масштаба 1: 3000000 [235], Карта ландшафтов Приморского края масштаба 1: 1000000 [243] и объяснительная записка к ней [244], Карта физико-географического районирования Приморского края [236] и др.

Для регионального ландшафтного синтеза особый интерес представляет сравнительно-статистический анализ ландшафтной карты масштаба 1: 500000. Поэтому внимание уделялось площадям ландшафтов, их видов, родов, классов, их сопоставлению в про- 
центном и долевом отношениях в пределах края [68]. Подсчитаны коэффициенты ландшафтной расчлененности [276]. Все количественные характеристики, снимаемые с карты, разделены на группы пространственных, морфологических и ландшафтных данных.

Проведенные исследования, базирующиеся на картографировании ландшафтов и их структур, оценке данных по изменению свойств ландшафтов и их пространственно-площадному распространению с учетом компонентно-средовой дифференциации, рассматриваются автором как базовые для комплексной оценки антропогенных преобразований природной среды, оптимизации природопользования, конструктивного начала в обеспечении экологической безопасности минерально-сырьевого природопользования Приморского края. Они могут служить основой многоцелевых естественно-научных и прогнозно-экономических исследований, в т.ч. при разработке концепций устойчивого развития регионов.

В отдельных лекциях рассматриваются вопросы практического применения исследования, которые определяются как реальным использованием полученных результатов, так и их потенциалом: они применимы для экологических оценок, палеогеографических, геологических реконструкций, регламентирования природопользования, проектирования строительства, прогноза природной обстановки и чрезвычайных ситуаций. Это интересно проектным организациям, Комитету по недропользованию Приморского края (текстовые и картографические оцифрованные материалы уже переданы в информационные фонды Комитета) .

Проведенные многолетние исследования - региональное звено продолжающихся многоплановых ландшафтно-экологических исследований Азиатской России: В. И. Булатова (1989, 1990, 1992); З. Г. Мирзехановой (1990-2008); А. Ф. Махиновой (2002); Т. И. Коноваловой (2006); В. М. Плюснина $(2003,2007)$; Д. В. Черных (2002, 2012); Ю. М. Семенова $(2004,2010)$ и др. В Забайкалье, Хабаровском крае, на всём юге Сибири подобные исследования составляют ландшафтно-географическую основу комплексной оценки антропогенных преобразований природной среды, типизации и классификации природных и антропогенных ландшафтов, проведения прогнозно-экономических исследований и решения задач, поставленных правительством России по освоению Сибири и Дальнего Востока.

Полученные данные необходимо рассматривать как регионально-территориальное звено в изучении модификации ландшафтов и в формировании политики природопользования стран АТЭС (Старожилов, 2009). Только совместными, межгосударственными, усилиями можно определить рациональную политику сохранения экологического баланса на территориях Приморья, Китая, Кореи, Японии и других стран АТЭС. Уже известно, что формированию природоохранно-экологической стратегии помогают ландшафтные карты, а применение ландшафтного подхода обеспечивает необходимую комплексность, пространственную сопряженность и научную достоверность. Предлагается рассмотреть, по примеру Европейской ландшафтной Конвенции, возможности межгосударственного распространения единого ландшафтного подхода и использования ландшафтных карт для изучения экологического равновесия и формирования экологической политики стран АТЭС. 


\section{Лекщия 2}

\section{ИСТОРИЯ СТАНОВЛЕНИЯ ЛАНДШАФТНОЙ ГЕОГРАФИИ}

Ландшафтоведение - направление физической географии, начавшее формироваться в конце XIX в. Основная идея физической географии XIX в-идея взаимосвязи, взаимообусловленности и взаимопроникновении природных географических компонентов (фундамент, рельеф, климат, почвы, растительность). Исторически эта идея реализовалась в двух направлениях и привела к развитию представлениий о географической оболочке с одной стороны и природных территориальных комплексах (ПТК) - с другой.

В учении о географической оболочке получила свое законченное выражение мысль о целостности географического пространства в глобальном масштабе, что определило предмет изучения общей физической географии. Понятие о природном территориальном комплексе, как конкретном региональном или локальном сочетании компонентов, легло в основу ландшафтоведения.

Географическая оболочка является единой, целостной материальной системой, но в ней отчетливо выделяются разнородные структурные части. Географическая оболочка пространственно дифференцирована как по вертикали, так и по горизонтали. По вертикали она имеет ярусное строение, что выражается в расположении основных частных геосфер в соответствии с плотностью слагающего их вещества. Имея неоднородный состав, географическая оболочка распадается на ряд частных, компонентных оболочек, или как сейчас принято говорить, геосфер: литосферу, гидросферу, атмосферу, биосферу и педосферу. На контактах атмосферы, гидросферы и литосферы происходит их наиболее активное взаимодействие, именно здесь наблюдается концентрация жизни, формируется биокосный компонент - почвы. Узкую контактную и наиболее активную пленку географической оболочки называют ландшафтной сферой. Это понятие было предложено в 1950 году Ю. К. Ефремовым.
Ф.Н. Мильков в своих трудах 1970-1980-х гг. развил представление о ландшафтной сфере, являющейся зоной прямого соприкосновения и активного взаимодействия литосферы, атмосферы и гидросферы, совпадающей с биологическим фокусом географической оболочки Земли. Ф.Н. Мильков дал определение ландшафтной сферы как совокупности ландшафтных комплексов, выстилающих сушу, океаны и ледниковые покровы [132]. В нее входят современная кора выветривания, почвы, растительность, животные организмы и приземные слои воздуха. В результате прямого соприкосновения и активного взаимодействия литосферы, атмосферы и гидросферы здесь образуются специфические природные комплексы - земные ландшафты.

\section{1 Становление современного ландшафтоведения}

В конце XIX в в России формируется мощная почвенно-географическая школа. Основателем ее стал профессор Петербурского университета В.В.Докучаев, величайшей научной заслугой которого было создание учения о почве. По В.В. Докучаеву, почва есть результат взаимодействия всех географических компонентов. Именно она оказалась замыкающим звеном в системе географических связей. Поэтому от изучения почвы оставался как бы один шаг до географического синтеза, и его сделал В.В. Докучаев: опираясь на учение о почве, он сделал широкие географические обобщения, заложил основы ландшафтоведения.

В.В. Докучаев хорошо понимал отрицательные стороны далеко зашедшей дифференциации естествознания. В 1898 г. он перешел к мысли о необходимости разработки новой науки о соотношениях и взаимоотношениях между всеми компонентами живой и мертвой природы и о законах их совместного развития. В 1898-1900 гг. он разрабатывал эту идею. Именно в эти годы вышла в свет серия статей, в которых В. В. Докучаев излагал свое учение о зонах природы, или естественноисторических зонах. Это учение послужило как бы введением к новой науке. Впервые зональность трактовалась как мировой закон, действия которого распространяются на все природные процессы, происходящие на земной поверхности. Зона в его трактовке - это природный комплекс высшего ранга, в границах которого все компоненты образуют взаимообусловленное единство. В.А. Докучаев, таким образом, сформулировал первый географический закон. 
Также он впервые осуществил на практике принцип комплексного полевого исследования конкретных территорий путем организации ставших знаменитыми экспедиций (1882-1898). В. В. Докучаев сочетал высокий теоретический уровень исследований с практической целенаправленностью. Главной его целью была научная разработка методов борьбы с засухой и другими неблагоприятными природными условиями степной зоны. Он воспитал плеяду географов-исследователей нового типа, которые развивали его идеи. В их числе А.Н. Краснов, Г.Ф. Морозов, Г. Н. Высоцкий, Г. И. Танфильев, Н. Н. Сибирцев, В. И. Вернадский, К.Д. Глинка. Его последователями стали Л.С. Берг, Б. Б. Полынов и др. Докучаевская географическая школа - явление уникальное в истории нашей науки по прогрессивности идей и влиянию, которое она оказала на дальнейшее развитие географии.

Докучаевская концепция природной зональности в начале XX в. прочно вошла в теорию и практику. Г.Н. Высоцкий еще в 1899 г. внес в нее существенные дополнения, а в 1905 г. предложил первый количественный критерий для разграничения зон - показатель атмосферного увлажнения в виде отношения годового количества осадков к испаряемости. Благодаря работам последователей В.В.Докучаева была конкретизирована система природных зон, их границы уточнялись по карте. Тем самым создавалась основа для синтеза в природном районировании.

С этого времени в научный обиход входит термин физико-географическое районирование. Первый опыт такого районирования, положивший начало переходу от отраслевых схем к комплексным, принадлежит Г.И. Танфильеву и относится к 1897 г. Танфильев разделил европейскую Россию на физико-географические области, полосы (зоны) и округа. Докучаевская традиция выразилась в том, что многие работы по районированию имели прикладную направленность. Так, Г.Ф. Морозова проблема прикладного районирования интересовала с позиции лесоводства, Г.Н. Высоцкий разрабатывал систему зон с целью научного обоснования дифференцированных приемов степного лесоразведения.

Накопленный в регионах опыт комплексных исследований с различными практическими задачами и на разных территориальных уровнях детальности приводил отечественных исследователей к все более твердому убеждению в объективном существовании закономерных взаимообусловленных территориальных сочетаний природных компонентов. В начале прошлого столетия эта идея воплотилась в учение о ландшафте. В течение десятилетия 1904-1914 гг. научное представление о ландшафте в разных формах было выдвинуто независимо друг от друга многими учеными, ибо идея ландшафта после работ В.В. Докучаева уже носилась в воздухе.

Г.Ф. Морозов в работе «Исследование лесов Воронежской губернии» сформулировал свой взгляд на ландшафт. Ландшафты - это естественные единицы, на которые распадается природа любой территории, они представляют собой «как бы фокусы, или узлы, в которых скрещиваются взаимные влияния общего и местного климата, с одной стороны, рельефа, геологических условий - с другой, растительности и животного мира - с третьей и т.д.» Автор подчеркивал необходимость генетического подхода к изучению ландшафтов.

Г.Н. Высоцкий самостоятельно развивал представление о ландшафте, который предпочитал называть русским термином «естественная округа, или местность». В статье «О карте типов местопроизрастаний» в 1904 году Г.Н. Высоцкий отметил, что различные местности должны отличаться однообразием условий местопроизрастания соответствующих растительных сообществ. В этой мысли заключено представление о морфологии ландшафта, получившее развитие значительно позднее. С другой стороны, «естественные округи» Г.Н. Высоцкий рассматривал как начальные единицы всей системы районирования: они объединяются в естественные области, а последние - в страны. Высоцкому также принадлежит идея создания ландшафтных карт. Интересные соображения о ландшафтах мы находим в работах А.А. Борзова, И. М. Крашенинникова, Р. И. Аболина. Однако научное понятие «ландшафт» в географическую науку ввел Л. С. Берг, ибо он впервые в 1913 году в статье «Опыт разделения Сибири и Туркестана на ландшафтные и морфологические области» высказал мысль, что именно ландшафты представляют собой предмет исследования географии.

Л. С. Берг определил ландшафт как «область, в которой характер рельефа, климата, растительного и почвенного покрова сливается в единое гармоническое целое, типически повторяющееся на протяжении известной зоны Земли». При всем несовершенстве это определение содержит чрезвычайно важное указание на связь между ландшафтом и природной (ландшафтной) зоной.

В русской географии до 1917 года еще не существовало разработанного учения о ландшафте, но идея ландшафта стала вхо- 
дить в научный обиход географов. Она создавала теоретическую платформу для объединения взглядов представителей различных отраслевых дисциплин и для разработки принципов и методов комплексных территориальных исследований.

Главная географическая идея 1920-х гг.- идея районирования. Опыт районирования дал возможность сформулировать принцип провинциальности, что явилось наиболее существенным вкладом в ландшафтную теорию.

Второе направление развития ландшафтно-географических идей в 1920-е гг. связано непосредственно с детальными полевыми исследованиями, проводившимися с прикладными целями, преимущественно для выявления и оценки земель. Многие исследователи пришли к убеждению, что наиболее плодотворные результаты при подобных исследованиях дает ландшафтный подход. Практически его реализация выразилась в зарождении полевой ландшафтной съемки и появлении первых ландшафтных карт. Пионерами ландшафтной съемки явились Б. Б. Полынов и И. В. Ларин. Ландшафтные съемки велись в крупных масштабах. В процессе съемок была доказана реальность существования природных территориальных комплексов и подтверждена тесная взаимообусловленность их компонентов.

В процессе проведения ландшафтных съемок выявилось многообразие природных территориальных комплексов и возникла необходимость установить их различные градации. Важнейшим итогом явилось определение наиболее дробной (элементарной) ступени ландшафтного деления, которую Б. Б. Полынов и И.М. Крашенинников называли элементарным ландшафтом, а И. В. Ларин - микроландшафтом (оба понятия соответствуют ранее введенной Р.И. Аболиным эпиморфе).

Наконец, еще одним важным научным результатом детальных ландшафтных исследований было появление первых идей в области динамики и эволюции ландшафта. Начало этому генетическиму направлению в ландшафтоведении было положено Б. Б. Полыновым.

Таким образом, отечественные географы приближались к созданию учения о ландшафте, однако разработанной ландшафтной теории еще не существовало. На рубеже 1920-30-х гг. наблюдается интерес географов к методологическим и теоретическим проблемам науки. Толчок к дискуссиям и теоретическим поискам дала в 1930 году известная работа Л.С. Берга «Ландшафтно-географические зоны СССР». Во введении к этой книге дается краткое изложение основ учения о ландшафте. Берг уточнил и дополнил свое первое определение ландшафта, привел примеры ландшафтов, рассмотрел вопрос о роли отдельных компонентов и их взаимодействии.

Интересные взгляды на ландшафт у Л.Г. Раменского (18841953). В своих работах 1930-х гг.- «О принципиальных установках типологии земель» и «Введение в комплексное почвенно-геоботаническое обследование земель» он дает понятие о ландшафте, который, по его мнению - сложная территориальная система, состоящая из разнородных, но сопряженных элементарных природных комплексов - эпифаций. Эпифации формируются внутри ландшафта на различных местоположениях и характеризуются однородными экологическими режимами и одним биоценозом.

Эпифации группируются в промежуточные комплексы, которые Л.Г. Раменский назвал урочищами (они связаны с самостоятельными формами рельефа, отдельными частями обширной речной поймы и др.). Вводя в науку понятия эпифации и урочища, Раменский развил идею морфологии ландшафта, намеченную Г.Н. Высоцким. Важнейшая же заслуга его перед ландшафтоведением состоит в том, что он указал на новый тип географических связей (горизонтальных) .

В 1930-е гг. учение о ландшафте обогатилось важными новыми идеями, но они еще не были объединены в стройную теоретическую систему.

\section{2 Ландшафтная география в России и в Приморье}

Массовое ландшафтное движение, по мнению А. Г. Исаченко, началось в середине 1950-х гг., его начало связано с именами Н.А. Солнцева, Ф. Н. Милькова, В. С. Преображенского, Д. Л. Арманда, Ю. К. Ефремова, самого А. Г. Исаченко, несколько позднее В. Б. Сочавы. Формируются ландшафтные школы. С тех пор ландшафтоведение прошло сложный путь и в настоящее время представляет собой развитое научное направление со значительным ветвлением по внутренним составляющим, широким спектром общенаучных и прикладных приложений. Теоретические и практические исследования этого периода к концу 80-х - началу 90-х гг. прошлого столетия нашли отражение в фундаментальных теоретических обобщениях, систематических сводках по ландшафтам СССР и всей суши, в ландшафтных картах СССР и мира, отдельных регионов. 
Географами при изучении ландшафтов на современном этапе рассматриваются различные стороны. Это прежде всего теория, методология, методы исследований и моделирование, структура и организация ландшафтов. Уделяется внимание динамике и функционированию ландшафтов, их эволюции, трансформации и модификации, ландшафтному планированию.

Обсуждаются возможности системного подхода, функционального и динамического анализа, регионального синтеза, формируются концепции структурно-генетическая, функционально-динамическая, выделяется горное ландшафтоведение, антропогенное обособляется эколого-ландшафтное направление.

Большое значение в развитие структурно-генетической концепции ландшафта имело распространение в 50-х гг. ландшафтных съемок. Инициаторами их выступили географы Московского университета под руководством Н.А. Солнцева, а в 1950-60-х гг съемки велись силами сотрудников Ленинградского, Львовского, Латвийского, Воронежского и других университетов. Развертывание полевых ландшафтных исследований имело решающее значение для дальнейшей разработки теории ландшафта. В 1948 г. Н.А. Солнцев, развивая идеи Л.Г. Раменского и Л.С. Берга, углубил представление о ландшафте и его морфологии. Согласно его определению, ландшафт - основная таксономическая единица в ряду природных территориальных комплексов; это генетически единая территориальная система, построенная из закономерно сочетающихся морфологических частей - урочищ и фаций. Это представление создавало теоретическую основу для ландшафтной съемки и создания ландшафтных карт различных масштабов. Фации были признаны объектом полевой съемки в крупных масштабах, урочище - в средних, ландшафты оказались оптимальными объектами мелкомасштабного картографирования. Постепенно в рамках структурно-генетической концепции получило развитие представление об иерархической организации соподчиненных морфологических единиц ландшафта. На современном этапе развития ландшафтоведения общепризнанными являются уровни: фация, урочище, местность, ландшафт (район). В результате в конце шестидесятых годов впервые появились обзорные ландшафтные карты отдельных республик и областей, в т.ч. как элементы содержания комплексных атласов. В связи с созданием карт возникла проблема классификации ландшафтов. Подробная классификация была разработана для территории СССР применительно к карте в масштабе 1: 4000000. Большое значение имеет разработанная В.А. Николаевым структурно-генетическая классификация ландшафтов, объектом которой выступает природная геосистема ранга «ландшафт» - таксон, расположенный на контакте локальных и региональных геосистем.

На развитие ландшафтоведения большое влияние оказали работы В.Б. Сочавы - основоположника учения о геосистемах. В 1970-1980-х гг. внедряется системный подход. По мнению В.Б. Сочавы «его особенность заключается в рассмотрении мира, его определенных частей как организованной, взаимосвязанной и взаимообусловленной системы... Общая теория систем является моделью, которая нацеливает на разнообразные связи и отношения в природе, что позволяет выделять и изучать строение и организацию природных объектов». По определению В.Б. Сочавы, геосистемы - это «... земные пространства всех размерностей, где отдельные компоненты природы находятся в системной связи друг с другом и как определенная целостность взаимодействует с космической сферой и человеческим обществом» [183]. Позднее учение о геосистемах было развито усилиями А.Д. Арманда, Н.Л. Беручашвили, А. М. Грина, М.Д. Гродзинского, К. Н. Дьяконова, Н. С. Касимова, В. Н. Солнцева, А.А. Крауклиса, В. С. Преображенского, Ю. Г. Пузаченко, А. Ю. Ретеюма, В.А. Снытко и многих других исследователей.

Большое внимание было уделено исследованию полиструктурности природных геосистем. Как отмечают К. Н. Дьяконов и Ю.Г. Пузаченко [52], на основе работ К. Г. Рамана, Э.Г. Коломыца, А. Ю. Ретеюма, В.Н. Солнцева была разработана теория полиструктурности и полигенетичности ландшафтного пространства, которая обусловлена вещественно-энергетическим взаимодействием в поверхностном слое Земли водных, воздушных, грунтовых и биотических масс. Выделяются пространственные и временные аспекты полиструктурности. В настоящее время усиливается интерес специалистов к вещественно-энергетическому обмену между биотическими и абиотическими компонентами, к биотической продуктивности ландшафта. В этом можно усматривать определенное влияние экологических концепций. Для современного этапа характерно повышенное внимание к изучению временных изменений геосистем, которые рассматриваются как пространственно-временные образования. Обновляется взгляд на ландшафт как саморегулирующую систему, способную восстанавливать нарушенное равновесие благодаря действию обратных связей между различными компонентами и элементами. 
Одновременно происходило развитие функционально-динамической концепции, основой которой являются исследования В. Б. Сочавы, А.А. Макуниной, А.Д. Арманда, Н.Л. Беручашвили, А.Г. Исаченко, В. В. Козина, А.А. Крауклиса, И.И. Мамай, В. С. Михеева, А. К. Черкашина и др. На современном этапе геосистема рассматривается функционирующей в пространстве и во времени. Под функционированием понимается устойчивая последовательность постоянно действующих процессов обмена и преобразования вещества, энергии и информации, обеспечивающая сохранение состояния ландшафта в течение значительного промежутка времени [152]. Динамика - изменения ландшафта, не сопровождающиеся изменениями его структуры, т.е. движение переменных состояний в пределах одного инварианта. Понятие инварианта введено в географию В.Б. Сочавой для обозначения «совокупности присущих геосистеме свойств, которые сохраняются неизменными при преобразовании геосистем». Развитие (эволюция) ландшафта, по мнению В.Б. Сочавы [183],- «необратимое направленное изменение, приводящее к коренной перестройке (смене) структуры ландшафта, к замене одного инварианта другим, т.е. к появлению новой геосистемы. Механизм развития ландшафта состоит в постепенном количественном накоплении элементов новой структуры и вытеснении элементов старой. Этот процесс, в конце концов, приводит к качественному скачку смене ландшафтов».

Формирование отмеченных выше направлений привело в целом к уточнению представлений о структурах, иерархических единицах морфологии ландшафтов различных масштабных уровней - локального, регионального и планетарного; познанию структурно-генетических, функционально-динамическо-эволюционных особенностей геосистем различных территорий. В частности, практика исследований равнинных и горных ландшафтов показала, что горные территории имеют принципиально отличительные от равнинных условия формирования, и это способствовало развитию горного ландшафтоведения. По мнению В. И. Булатова и Д.В. Черных [17, 282], это выявилось первоначально в 60-х гг. XX века, когда при исследовании горных районов обнаружились существенные различия ландшафтной структуры и организации горных и равнинных систем. Различия отмеченных систем на примерах гор Средней Азии, Кавказа, Забайкалья привели к выделению горного ландшафтоведения. В. М. Плюснин [157] связывает его развитие с работами Н.А. Гвоздецкого,
Г.Н. Миллера, В.С. Преображенского, В. Б. Сочавы, А. Е. Фединой, В.А. Николаева, Н.Л. Беручашвили. Были выявлены существенные различия в высотной поясности, по тепловому балансу, условиям увлажнения, водному режиму и др. характеристикам. Кроме того, для горных ландшафтов характерны уязвимость к воздействию природных и антропогенных факторов, широкое развитие склоновых процессов, маломощный чехол продуктов выветривания коренных пород, высокая динамичность, неустойчивость природных систем [21, 57, 157, 158].

По данным А.Г. Исаченко [73] под горным ландшафтом понимается часть ландшафтного яруса в пределах самостоятельных систем высотных поясов с однородным структурно-литологическим и геоморфологическим строением. По Г. П. Миллеру [130] это обособленная в геологическом фундаменте и рельефе целостная горная область положительных и отрицательных макрокомплексов, состоящая из ряда высотных местностей. Важная особенность горных ландшафтов по В. М. Плюснину [157, 158] их структурная и функциональная сложность, которая выражается в разнообразии систем.

Существенная черта современного этапа - расширение сферы прикладных ландшафтных исследований. В течение десятилетий традиционной сферой приложения принципов и методов ландшафтоведения было сельское хозяйство. В 1860-х гг. ландшафтоведы начали участвовать в архитектурно-планировочных разработках. В дальнейшем особенно популярными стали ландшафтно-рекреационные исследования. К другим прикладным направлениям следует отнести ландшафтно-инженерное и ландшафтно-мелиоративное. Свою главную прикладную задачу многие специалисты видят в том, чтобы выявить ландшафтные основы природной среды как базы освоения территорий.

На основе полученных данных прикладных исследований формируется антропогенное направление, в котором человек и результаты его деятельности рассматриваются не только как внешний фактор, нарушающий ландшафт, но и как равноправный компонент системы. Одним из основоположников антропогенной концепции является Ф.Н. Мильков [133, 134]. Методологическую основу антропогенного ландшафтоведения составляют также концепции агроландшафта [147], геотехнических систем [167] культурного ландшафта [168] и ландшафтного дизайна [148]. По иному рассматривает антропогенный ландшафт А.Г. Исаченко: он считает, что лучше говорить о степени антропогенной модифи- 
кации геосистем, учитывая, что антропогенные трансформации геосистем находят свое выражение в изменении их структуры и динамики, которые неодинаково проявляются в системах разного уровня. Им, а также некоторыми другими авторами, предложены коэффициенты антропогенной модификации.

Достижения отечественной и зарубежной географии имеются в изучении соотношения и взаимодействия природных и антропогенных факторов, выявления источников, процессов и последствий антропогенных изменений окружающей среды, особенностей региональных сочетаний экологических проблем, обусловленных экономическими и другими факторами. Важно то, что в итоге был выработан особый общенаучный метод (или подход), применение которого имеет широкие перспективы. Сущность этого подхода состоит в анализе наблюдаемых явлений и проблем в связи с ландшафтной структурой территории и в зависимости от сотворчества, как писал В.Б. Сочава, человека и природной среды [184]. Объективная оценка роли географической среды в жизни и развитии общества в сочетании с ландшафтным подходом открывает новые возможности для объяснения закономерностей в хозяйственном освоении территории, использовании комплекса ресурсов, создании экологически безопасных условий освоения и т.д. Теоретический потенциал ландшафтоведения, как ядра физической географии, несмотря на наличие нерешенных или спорных вопросов, имеет фундаментальное значение для разработки генеральной стратегии поведения человека в его природном окружении.

В заключение следует сказать о соотношении физической географии, ландшафтоведения и геоэкологии. Сам предмет геоэкологии до сих пор строго не определен. Н.Ф. Реймерс считал ее разделом экологии, исследующим экосистемы (геосистемы) высоких иерархических уровней, достаточно близким к географии. А. Г. Исаченко отмечает, что в теоретическом плане геоэкология мало отличима от комплексной физической географии и не случайно иногда ставится знак равенства между геоэкологией и экологией ландшафта. Акад. РАН В.И. Осипов в 1993 г. определил объектом геоэкологии геосферные оболочки Земли, а предметом - все знания о них, включая изменения под влиянием природных и техногенных факторов. Ф.Н. Мильков, предложивший еще в 1966 г [131] словосочетание «ландшафтная география», отмечал, что все науки, имеющие объектом изучения гео-Землю, могут претендовать на первородство с геоэкологией, рассматриваемой как наука междисциплинарная, синтезирующая законы экологии с закономерностями всех наук о земле - географии, геологии, геофизики, геохимии, биологии. А. Г. Исаченко пошел по пути выделения экологической географии [79], Ф.Н. Мильков предложил, в связи с реализацией в географии хорологического принципа, выделять экографию - описательную геоэкологию. Её вариант, связанный с анализом техногенных воздействий и экологических ситуаций - это экодиагностика территорий (по Б.И. Кочурову [107]). В.И. Булатов, проанализировав систему интересов географии и экологии, пишет о научном направлении, которое можно назвать ландшафтно-географической экологией [22].

Представляемая работа лежит, по мнению автора, в сфере научных интересов ландшафтной географии, включающей, помимо ландшафтного анализа и синтеза, природное районирование территории, её регионально-территориального ядра. Своеобразие Приморья не только в его палеогеографии, но и в континентально-океанической дихотомии, законе фундаментального дуализма суши и моря, парности в организации и функционировании, единстве и противоположности приморских и континентальных ландшафтов и геосистем.

Особое значение имеет оценка изученности природы региона и его окружения, вклада огромного коллектива ученых, много лет работавших в Приморье и обеспечивших современный уровень естественно-географических знаний о нем. Основные направления естественно-научных исследований, из которых формируется теоретическая основа региональной ландшафтной географии, объект её изучения - межкомпонентные, комплексные природные взаимосвязи, а также важнейшие практические приложения, отражены в табл. 1. Краткая (поскольку детальная просто невозможна) информационно-библиографическая сводка показывает диапазон научного поиска и включает:

1) перечень имеющихся направлений природно-региональных исследований;

2) важнейшие научные публикации по этим темам, приведенные в библиографическом списке диссертации;

3) работы, выполненные автором. Этот раздел показывает авторский диапазон многолетнего научного поиска, его вклад, отраженный как в публикациях, так и учебных комплексах и пособиях.

По многим из перечисленных в таблице 1 направлений, прямо затрагивающих сферу ландшафтной географии, в работе будет 
Таблица 1

Направления поиска, основные публикации и авторские работы

\begin{tabular}{|c|c|c|}
\hline Направления поиска & $\begin{array}{c}\text { Основные } \\
\text { публикации }\end{array}$ & $\begin{array}{c}\text { Авторские } \\
\text { работы }\end{array}$ \\
\hline $\begin{array}{l}\text { Геологическое строе- } \\
\text { ние и поверхностные } \\
\text { отложения }\end{array}$ & $14,38,48,96,97,100,121$ & $\begin{array}{l}206,231,237 \\
264,270\end{array}$ \\
\hline $\begin{array}{l}\text { Рельеф и экзогенные } \\
\text { процессы }\end{array}$ & $\begin{array}{l}10,98,103,112,113,125 \\
126,174,301\end{array}$ & $219,238,245$ \\
\hline $\begin{array}{l}\text { Климатические фак- } \\
\text { торы }\end{array}$ & $\begin{array}{l}27,29,58,99,124,169 \\
173,284,286,297\end{array}$ & \\
\hline $\begin{array}{l}\text { Речные бассейны, } \\
\text { сток, водная эколо- } \\
\text { гия }\end{array}$ & $\begin{array}{l}28,16,86,101,102,122, \\
123,181,219,302\end{array}$ & 246,263 \\
\hline $\begin{array}{l}\text { Леса, растительность } \\
\text { и биоресурсы }\end{array}$ & $\begin{array}{l}2,23,24,31,33,44,54, \\
115,119,151,181,274,285\end{array}$ & \\
\hline Почвенный покров & $\begin{array}{l}63,64,69,71,108,128 \\
145,159,163,164,165\end{array}$ & 259,262 \\
\hline Палеогеография & $\begin{array}{l}11,65,67,72,97,98,100, \\
149,\end{array}$ & 207 \\
\hline $\begin{array}{l}\text { Экогеохимия при- } \\
\text { родных сред, геохи- } \\
\text { мия ландшафта }\end{array}$ & $\begin{array}{l}3,15,109,110,121,127 \\
129\end{array}$ & $\begin{array}{l}208,230,238 \\
265,267\end{array}$ \\
\hline $\begin{array}{l}\text { Антропогенная } \\
\text { трансформация, тех- } \\
\text { ногенез }\end{array}$ & $\begin{array}{l}34,60,61,91,111,116, \\
154,288,300\end{array}$ & $245,255,260$ \\
\hline $\begin{array}{l}\text { Ресурсоведение, } \\
\text { управление природо- } \\
\text { пользованием }\end{array}$ & $\begin{array}{l}8,35,56,59,150,156,223, \\
299\end{array}$ & $\begin{array}{l}202,211,236, \\
240,247,256, \\
257,269\end{array}$ \\
\hline $\begin{array}{l}\text { Экогеография, экс- } \\
\text { пертиза экологиче- } \\
\text { ская }\end{array}$ & $\begin{array}{l}20,41,42,79,84,85,105 \\
136,140,146,160,162 \\
172,178,275,304,305\end{array}$ & $\begin{array}{l}234,248,266, \\
280\end{array}$ \\
\hline $\begin{array}{l}\text { Экологическая по- } \\
\text { литика, устойчивое } \\
\text { развитие }\end{array}$ & $\begin{array}{l}32,104,114,136,175,176 \\
177,278\end{array}$ & $\begin{array}{l}212,221,254, \\
258,271\end{array}$ \\
\hline $\begin{array}{l}\text { Тематическое карто- } \\
\text { графирование и рай- } \\
\text { онирование региона }\end{array}$ & $\begin{array}{l}7,9,37,62,81,83,89,90 \\
92,93,94,106,159,162 \\
170,171,273,281,283\end{array}$ & $\begin{array}{l}206,209,214, \\
232,233,235, \\
236,240,243, \\
244\end{array}$ \\
\hline
\end{tabular}

приведена необходимая информация. Отдельно будет рассмотрено место Приморья в системе ландшафтов СССР (России) (по работам А. Г. Исаченко и И.С. Гудилина) [77, 117].

\section{Контрольные вопросы}

1. Когда началось формироваться ландшафтоведение как направление физической географии?

2. Раскройте понятие географическая оболочка и какие разнородные структурные части она объединяет.

3. Раскройте понятие дифференциации географической оболочки.

4. Раскройте понятие ландшафтная сфера.

5. Кто создал учение о почве и заложил основы ландшафтоведения?

6. Кто заложил основы учения о зонах?

7. Кто впервые осуществил на практике принцип комплексного исследования конкретных территорий в прикладных целях?

8. Когла в научный обиход входит термин физико-географическое районирование?

9. Когда идея взаимосвязанных и взаимообусловленных компонентов вложилась в учение о ландшафте?

10. Как формулировали свои взгляды на ландшафт Г.Ф. Морозов, Г. В. Высоцкий, А.А. Борзов, И. М. Крашененников, Л.С. Берг.

11. Раскройте понятие - принцип провинциальности.

12. Раскройте понятие - полевая ландшафтная съёмка.

13. Когда появились первые идеи в области динамики и эволюции ландшафта?

14. Когда началось массовое ландшафтное движение?

15. С какими именами ученых связано массовое ландшафтное движение?

16. Какие ландшафтные концепции формируются к концу столетия?

17. Раскройте понятие «горное ландшафтоведение».

18. Когда сформировалось прикладное направление?

19. Раскройте соотношение ландшафтоведения и геоэкологии.

20. Какие основные направления естественно-научных исследований развиваются в ландшафтной географии в Приморье? 


\section{Лекщия 3}

\section{ЛАНДШАФТНЫЙ ПОДХОД В РЕШЕНИИ ПРИРОДООХРАННО-ЭКОЛОГИЧЕСКИХ ПРОБЛЕМ: ВОПРОСЫ ТЕОРИИ}

Впервые обратил внимание на роль географических исследований в решении экологических проблем В.Б. Сочава. И.П. Герасимов [39] определил экологический подход в качестве общенаучного для всех географических исследований. А. Г. Исаченко [79] считает, что география больше других наук подготовлена к разработке экологической концепции. С течением времени экологический принцип в географии стал завоевывать все более широкие позиции, в первую очередь при исследовании экосистем и ландшафтов и связанных с ними экологических проблем.

Основой изучения экологических проблем в ландшафтной географии является учение о современных ландшафтах - природных, природно-антропогенных системах (геосистемах). В исследованиях разных географов, внесших вклад в разработку этого учения, последние рассматриваются под различными названиями - «современные ландшафты», «антропогенные ландшафты», «антропогенные модифицированные ландшафты» и др. [3, 30, 75, 78, 82, 102]. Несмотря на различия в терминологии, общее понимание авторами сущности природно-антропогенной геосистемы является достаточно близким и опирается на представление о современных ландшафтах как о комплексных природно-антропогенных системах, возникших в результате пространственно-временного взаимопроникающего и взаимосвязанного взаимодействия человека и природы на современном уровне развития географической среды.

Для экологических исследований важна практическая реализация ландшафтного подхода. В частности, К.Н. Дьяконов [50-53], который так же, как и его предшественники и коллеги - В. В. Докучаев [55]; Л.С. Берг [12, 13]; А.Д. Арманд [4-6], М.Д. Гродзинский [47], В.С. Преображенский [161]; В.А. Снытко
[178]; Н.А. Солнцев [179]; В. Б. Сочава [180-184]; А. А. Григорьев $[45,46]$; А. Г. Исаченко [73-80],- заостряет внимание на необходимости практической реализации ландшафтного подхода. При этом сущность этого подхода им определяется, во-первых, индивидуальностью природы земной поверхности, организованной в сочетания ПТК и образующих относительно однородные по генезису территории, называемые ландшафтами; во-вторых, их пространственно-временной иерархической структурой, и в третьих, причинно-следственных взаимосвязями между отдельными компонентами.

На Дальнем Востоке в последние годы усилилось практическое применение ландшафтного подхода при изучении и решении экологических проблем и ситуаций тех или иных территорий. Большое значение имеют исследования 3.Г. Мирзехановой [137-140 и др.]; В. С. Михеева [141-144], С. С. Ганзея [35]; П.Я. Бакланова [8, 40]; Е. М. Климиной [87-91]; С. М. Говорушко [41-43]; А. М. Короткого, Т.Р. Макаровой [102]; В.Т. Старожилова и др. [193-271]; и др. Эта территория вошла в ландшафтные карты СССР масштабов 1: 2500000 (отв. ред. И. С. Гудилин, 1980) [117] и 1: 4000000 (науч. ред. А. Г. Исаченко, 1985 [77]. В 1983 г. впервые для Приморского края составлена в масштабе 1: 500000 карта ландшафтной типизации (Старожилов, Мостовой, 1983 г. [202, 206]). В ней отражены результаты определения компонентной специфики ландшафтов, разработки ландшафтной классификации, изучения и картографирования структур ландшафтов, выделены типы, классы, семейства, виды ландшафтов и типы местностей. На основе этих материалов в 1983 г. автором также составлена карта физико-географического районирования в масштабе 1: 1000000 , на которой выделены округа, провинции и области. Результаты исследований использовались в качестве базовых основ решения задач природопользования. В частности, изучались возможности применения ландшафтных материалов для целей проведения ландшафтно-геохимических поисков минерально-сырьевых объектов. В итоге была составлена карта поисковых регионов, в пределах которых, по результатам изучения ландшафтных обстановок, даны рекомендации по применению методов поисков месторождений полезных ископаемых производственными и научными организациями Приморья и Дальнего Востока. В последующие годы автором, как отмечалось выше, были составлены и изданы региональные ландшафтные карты Приморья; 
1. Карта ландшафтов Приморского края масштаба 1: 1000000.Владивосток: Электронные карты Приморского края. ТИГ ДВО PAH, 2006.

2. Карта физико-географического районирования Приморского края масштаба 1: $1000000 .-$ Владивосток: Электронные карты Приморского края. ТИГ ДВО РАН, 2006.

3. Карта ландшафтов Приморского края масштаба 1: 500000 (Москва, ВНТИЦ, 2007) .

4. Карта ландшафтов Приморского края масштаба 1: 3000000 (Атлас Приморского края. Владивосток, 2008) .

5. Карта физико-географического районирования Приморского края масштаба 1: 8000000 (Атлас Приморского края. Владивосток, 2008) .

6. Карта ландшафтов Приморского края масштаба 1: 1000000. (Владивосток, 2009).

Важное значение придается исследованиям по природоохранно-экологической оценке ландшафтов. Это связано с тем, что именно от их свойств и состояния зависят такие важные для человека и одновременно уязвимые при антропогенных воздействиях функции, как средозащитная и ресурсовоспроизводящая [107].

Известно, что в полной мере эти функции способны выполнять ландшафты, находящиеся в ненарушенном состоянии или управляемые человеком. Если же природные компоненты оказываются нарушенными, выполнение названных функций становится неполным или совсем прекращается. Это, естественно, приводит к ущербу, выражающемуся через снижение урожаев, потерю качества и истощение ресурсов. Иначе говоря, степень нарушения природных компонентов ландшафтов (фундамента, рельефа, климата, вод, почв, растительности) в значительной степени влияет на степень удовлетворения человеческих потребностей. Это означает, что все свойства и состояние природной среды, свидетельствующие о степени ее благополучия (неблагополучия), оказываются экологически значимыми для человека. В этом заключается суть экологической оценки ландшафта [107].

При оценке экологических показателей ландшафтов важное место имеют значение принципы классификации, структура и содержание легенды ландшафтных карт исследуемых территорий. Они рассматриваются нами как базовая информационная основа, отражающая региональную специфику, экологически значимые свойства ландшафтов. Последние могут способствовать или не способствовать возникновению экологических проблем, они же являются определяющими для жизнедеятельности человека (абсолютные отметки, температурный режим и пр., табл. 2).

Отбор средоформирующих и жизнеобеспечивающих свойств является одним из ключевых моментов в ходе исследования, поскольку необходимо определить начало отсчета при установлении уровня изменений этих свойств, свидетельствующих о возникновении экологических проблем. Отбор свойств должен быть строго ранжирован по классификационным единицам ландшафтов (в работе это область, провинция, округ, класс, подкласс, род, вид, местность).

Ландшафтные материалы, в частности региональные, рассматриваются как основа для изучения ландшафтной и экологической дифференциации территорий. Исследование ландшафтов Приморского края выявляет значительную их дифференциацию. По сопряженным компонентам (фундамент, рельеф, климат, воды, почвы, растительность) и в соответствии с закономерностями ландшафтной дифференциации они разделяются на классы, подклассы, роды, виды, местности. Отмеченные иерархические единицы характеризуются ландшафтными количественными и качественными свойствами, которые сравниваются, а далее с учетом их специфики выявляются благоприятные или неблагоприятные для возникновения экологических проблем ландшафты.

Важно то, что ландшафтные материалы, структура и организация ландшафтов являются географической матрицей для изучения уровня антропогенных нагрузок и, в зависимости от результатов этого анализа, экологических ситуаций. Антропогенные нагрузки отображаются графически на ландшафтных картах, затем изучается уровень экологических изменений природного ландшафта, они сравниваются между собой с учетом признанных экологических параметров и далее определяется их состояние и степень благополучия для человека и отдельных направлений природопользования.

Основываясь на картографировании ландшафтов Приморского края, отметим, что каждая иерархическая ячейка ландшафта характеризуется покомпонентным (фундамент, рельеф, климат, почвы, растительность) и совокупным ландшафтным вещественным, энергетическим и информационным потенциалами, которые нужно использовать при решении экологических задач [223, 239, 240, 248-252, 257-261 и др.]. Проведенные работы подтвердили, что при экологических исследованиях важно учитывать все компоненты ландшафта, а также палеогеографические факторы, 


\begin{tabular}{|c|c|c|c|c|}
\hline & 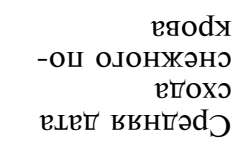 & 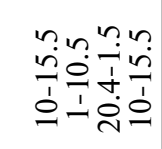 & 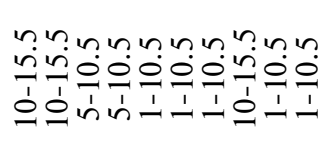 & 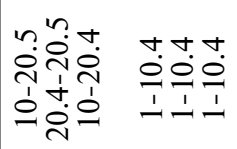 \\
\hline 胥 & 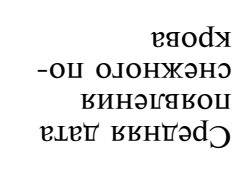 & 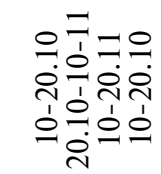 & 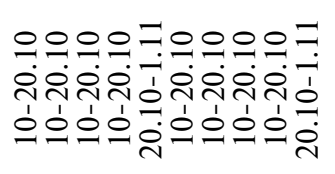 & 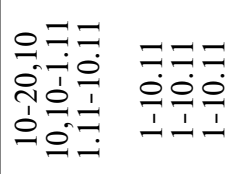 \\
\hline 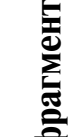 & 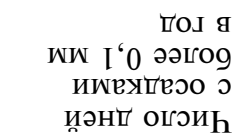 & 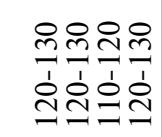 & 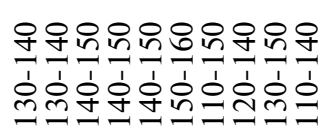 & 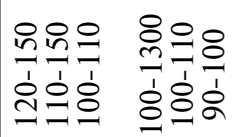 \\
\hline 플 & 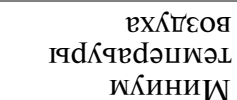 & 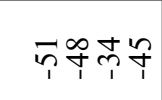 & 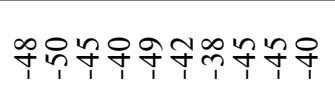 & 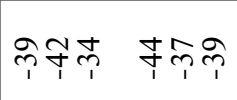 \\
\hline فำ & 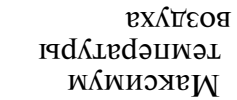 & ñׁñn & 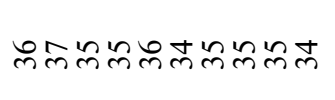 & n̄nm \\
\hline 丞 & 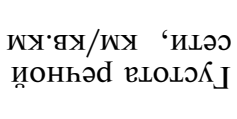 & 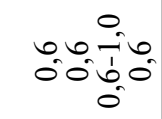 & 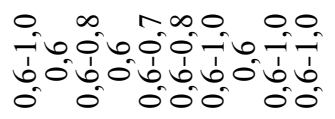 & 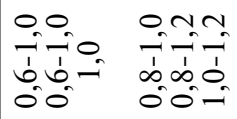 \\
\hline 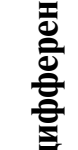 & 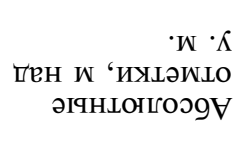 & 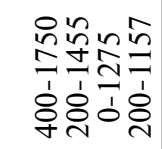 & 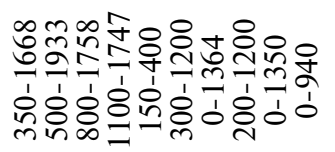 & 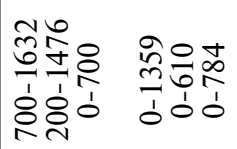 \\
\hline 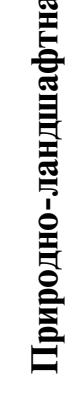 & $\begin{array}{l}\text { вияоц } \\
\text { ஈodl }\end{array}$ & 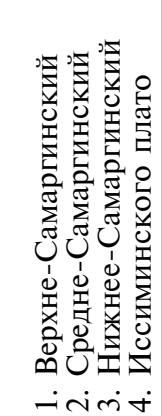 & 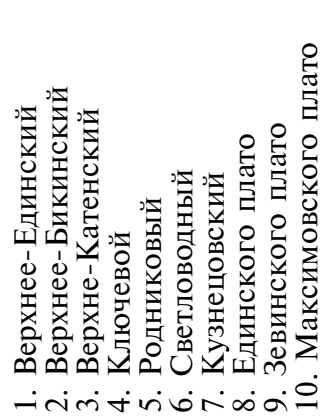 & 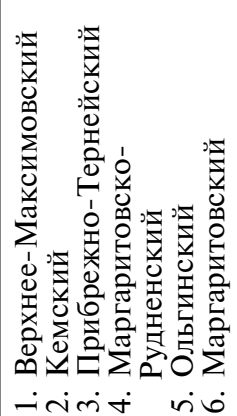 \\
\hline & випнияодШ & $\begin{array}{c}\text { вехониј } \\
\text {-dекеว · I }\end{array}$ & $\begin{array}{c}\text { вехонигу } \\
\text {-єцохиว-оdəgəว } \tau\end{array}$ & 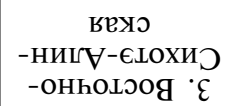 \\
\hline & q.วยเоO & \multicolumn{3}{|c|}{ 1כ } \\
\hline
\end{tabular}

поскольку многое определяется тектоническими особенностями территории, геохимической и минеральной спецификой, которые определяются составом вещественных комплексов фундамента ландшафтов. Тектонический режим определяет потенциал динамики и стабильности, а вещественные комплексы, являясь поставщиками материала (геохимического, минерального и т.д.), характеризуют вещественный потенциал ландшафтных иерархических единиц [257]. В целом речь идет о геологическом потенциале развития ландшафтов, о геологическом качестве, которое понимается как способность фундамента ландшафтов за счет собственного геологического природного потенциала в течение длительного времени сохранять и поддерживать динамику развития и вещественно-природный потенциал территории.

Ландшафты и геосистемы как основа экологических исследований предстают в научном поле как разнопорядковые узловые физико-географические ячейки пересекающихся, взаимообусловленных, взаимопроникающих друг в друга энергетических, вещественных и информационных потоков. В результате взаимодействия последних создается в конечном итоге качественное и количественное природное содержание всех иерархических ландшафтных единиц соответствующих территорий. Это в свою очередь создает предпосылку сравнительного анализа ландшафтных структур по качественным и количественным показателям, определяет природный ландшафтный потенциал ландшафтных качеств ниши жизни человека. В связи с этим выдвигается представление о ландшафтном качестве экосистем, под которым понимается способность ландшафта за счет собственного потенциала (сопряженного геологического, рельефного, климатического, почвенного, растительного) в течение длительного времени сохранять и поддерживать устойчивый природный уровень функционирования территорий [212, 257] .

Для экологических исследований важно то, что ландшафт имеет строгое территориальное физико-географическое положение, он обладает локальными и региональными свойствами, которые имеют качественные и количественные показатели. Ландшафт, выраженный в природных границах, является географической основой экологической организации территорий.

В Приморском крае до недавнего времени не было необходимых ландшафтных карт. Это значит, что не было условий для 
комплексной оценки последствий минерально-сырьевого природопользования. Поэтому в связи с ростом внимания государства к обеспечению экологической стабильности территорий в районах интенсивного природопользования была поставлена задача разработать научные основы составления карты масштаба 1: 500000 для Приморья, отразить и оценить техногенные преобразования ландшафтов при минерально-сырьевом природопользовании в крае. Для этого было сделано следующее:

1. Детально проанализированы, с учетом основных положений теории ландшафтной географии, компонентные особенности ландшафтов.

2. Выявлены закономерности формирования структуры, организации и пространственной дифференциации ландшафтов.

3. Разработана, с учетом российского опыта, региональная классификация ландшафтов.

4. Создана ландшафтная карта ландшафтов масштаба 1: 500000.

5. Установлен статус центров угольного и горнорудного минерально-сырьевого природопользования в системе ландшафтов региона.

6. Выявлены и оценены техногенные преобразования ландшафтов при минерально-сырьевом природопользовании в Приморском крае.

В последующих лекциях приводятся характер и результаты исследований, направленных на решение этих задач.

\section{Контрольные вопросы}

1. Кто впервые обратил внимание на роль географических исследований в решении экологических проблем?

2. Что ландшафтная география предлагает использовать как ландшафтную основу изучения экологических ситуаций и проблем?

3. Для экологических исследований важна практическая реализация какого географического подхода?

4. Раскройте понятие ландшафтный подход (метод) .

5. С какими учеными связано усиление применения ландшафтного подхода в экологии на Дальнем Востоке?

6. Какие ландшафтные карты Приморья были изданы в последнее десятилетие?

7. Раскройте понятие экологической оценки ландшафта.

8. Какие ландшафтные материалы рассматриваются как основа экологической дифференциации территорий?
9. Что является географической матрицей для изучения уровня антропогенных нагрузок?

10. Важно ли при экологических исследованиях учитывать все компоненты ландшафта?

11. В Приморье разработана легенда и составлена региональная карта ландшафтов или нет?

12. Какие основные вопросы решались при создании ландшафтной карты Приморья масштаба 1: 500000 ? 


\section{Лекщия 4}

\section{РЕГИОНАЛЬНАЯ ПРИРОДНО-КОМПОНЕНТНАЯ СПЕЦИФИКА ПРИМОРЬЯ (фундамент, рельеф)}

Приморский край расположен в зоне перехода Евразийского континента к Тихому океану и входит в состав Амуро-Приморской физико-географической страны [277]. Природные условия территории достаточно разнородны, что связано как с ее географическим положением, так и со сложной геологической, геоморфологической и климатической историей развития. Те или иные части региона имеют значительные компонентные различия, что отмечали многие исследователи: А.Ф. Будишев, М.И. Венюков, Н. М. Пржевальский, В. К. Арсеньев и др. Важное значение имели работы В.Л. Комарова, Ю.А. Ливеровского, В. В. Никольской, Б. П. Колесникова, Г.Э. Куренцовой, А. И. Куренцова, В. Б. Сочавы, Г.И. Иванова, В.А. Розенберга, А. М. Короткого, В. Г. Храмцовой, А. М. Шеметовой, М.П. Стороженко, Г.С. Ганешина и многих других. Однако большинство исследований было направлено на изучение отдельных компонентов природных сред, а ландшафтного анализа таких составляющих, как твердые горные породы и рыхлые отложения, рельеф, климат, воды, почвы, растительность, для целей классификации и картографирования ландшафтов не проводилось. Поэтому нами сделан специальный анализ отмеченных компонентов ландшафтов [193-271]. Ниже приводится характеристика особенностей фундамента, рельефа, климата, почв, растительности. При описании компонентов ссылки на литературу минимизированы, часть из них есть в библиотаблице лекции 1 , даются только самые необходимые.

\section{1 Фундамент и рыхлые отложения ландшафтов}

Фундамент ландшафтов. Современное физико-географическое единство территории Приморского края предопределено не только ходом геоморфологической, климатической эволюции, но и сложной историей геологического развития и формированием в различных структурно-тектонических зонах разнообразных осадочных, магматических, метаморфических пород, современных рыхлых отложений и образованием фундамента (выражено в петрографическом составе и условиях залегания горных пород, тектоническом режиме развития территории [95]). Рассматривая целостность природы, вытекающую из взаимопроникновения друг в друга, взаимосвязанности и взаимообусловленности ее компонентов и факторов, в т.ч. фундамента как вещественного компонента и фактора ее эволюции, можно говорить о том, что и ответственные за формирование ландшафтов тектонические режимы (рубежные, флуктуационные и др.) и вещественные комплексы, консервативные компоненты, играют значимую роль в формировании структуры и пространственной организации и эволюции ландшафтов Приморского края [197, 198, 200 и др.]. Поэтому, исходя из представления о равнозначности всех компонентов и факторов динамики ландшафтов и слабой, с позиций ландшафтной географии изученности его фундамента, были проведены дополнительные исследования.

Для географической оценки фундамента использованы материалы геолого-съемочных работ автора масштаба 1:50000, как фондовые, так и опубликованные [193-271]. В их числе, производственный отчет «Районирование территории Приморского края по геологическим и ландшафтно-геохимическим условиям проведения поисков, выполненного Центральной геохимической партией в 1980-1981 гг.» [206], отчет по теме № 253 «Обобщение материалов и составление прогнозной карты по фосфоритам Приморского края в масштабе 1: 500000» (к отчету приложена составленная автором карта формаций Приморского края). Проведена классификация вещественных комплексов плотных и рыхлых пород, определено их положение в структурно-тектонических зонах и физико-географических областях и провинциях Приморского края. Выделены стратифицированные вещественные комплексы фундамента ландшафтов, такие как алевролитовопесчаниковый, сланцевый и др. (всего 30 комплексов). Наименование вещественному комплексу дано по преобладающим в их составе петрографическим разностям горных пород, например, по преобладанию в комплексе алевролитов и песчаников присвоено название - алевролит-песчаниковый вещественный комплекс, и так далее. Выделены также по возрасту и составу интрузивные, 
экструзивные и эффузивные комплексы (26 комплексов). Рыхлые современные отложения подразделяются на сформированные на породах литифицированных комплексов; на интрузивных, экструзивных и эффузивных породах; образованные на рыхлых отложениях с разделением на обвально-оползневые, аллювиальные горных и равнинных рек и др. Обобщение геологических материалов и ландшафтное картографирование определили конкретные ландшафтные контуры вещественных комплексов (они будут отмечены ниже в гл. 3 «Виды и местности»). В этом же разделе анализируются общие закономерности распространенности вещественных комплексов фундамента Самаргинской, Северо-Сихотэ-Алинской, Западно-Сихотэ-Алинской, Центрально-Сихотэ-Алинской, Восточно-Сихотэ-Алинской, УссуриХанкайской, Восточно-Маньчжурской и Южно-Приморской физико-географических провинций (рис. 1) [215, 236, 251, 257, 261] и рассмотрены основные генетические типы рыхлых отложений ландшафтов.

Фундамент Самаргинской провинции, охватывающей бассейны рек Самарга, Единка, Венюковка и в их верховьях отроги осевого хр. Сихотэ-Алинь, сложен преобладающим алевролитпесчаниковым вещественным комплексом. Он прорывается позднемезозойскими интрузиями преимущественно кислого состава. На значительных площадях вещественный комплекс перекрыт меловыми вулканитами Восточно-Сихотэ-Алинского вулканического пояса и неогеновыми базальтоидами зон рифтогенной активизации Сихотэ-Алиня. Фундамент на 99,5\% закрыт чехлом рыхлых образований и залегает на глубине от 0 м (скальные выходы) до 5-10 м.

В составе фундамента Северо-Сихотэ-Алинской провинции, охватывающей территорию верхнего течения р. Бикин со всеми его притоками, до западной границы Верхне-Бикинской депрессии и бассейна рек восточного макросклона Сихотэ-Алиня (Kaбанья, Светлая, Кузнецовка, Максимовка), преобладают породы алевролит-песчаникового вешественного комплекса. Пятую часть занимают базальты плато (Единское, Зевинское, Максимовское) зон палеоген-неогеновой рифтогенной активизации. Породы алевролит-песчаникового комплекса прорываются многочисленными, сравнительно мелкими интрузиями кислого, реже среднего, состава. Фундамент закрыт чехлом рыхлых полигенетических отложений и залегает на глубине от 0 м (скальные выходы) до 5-10, редко $20 \mathrm{м}$.

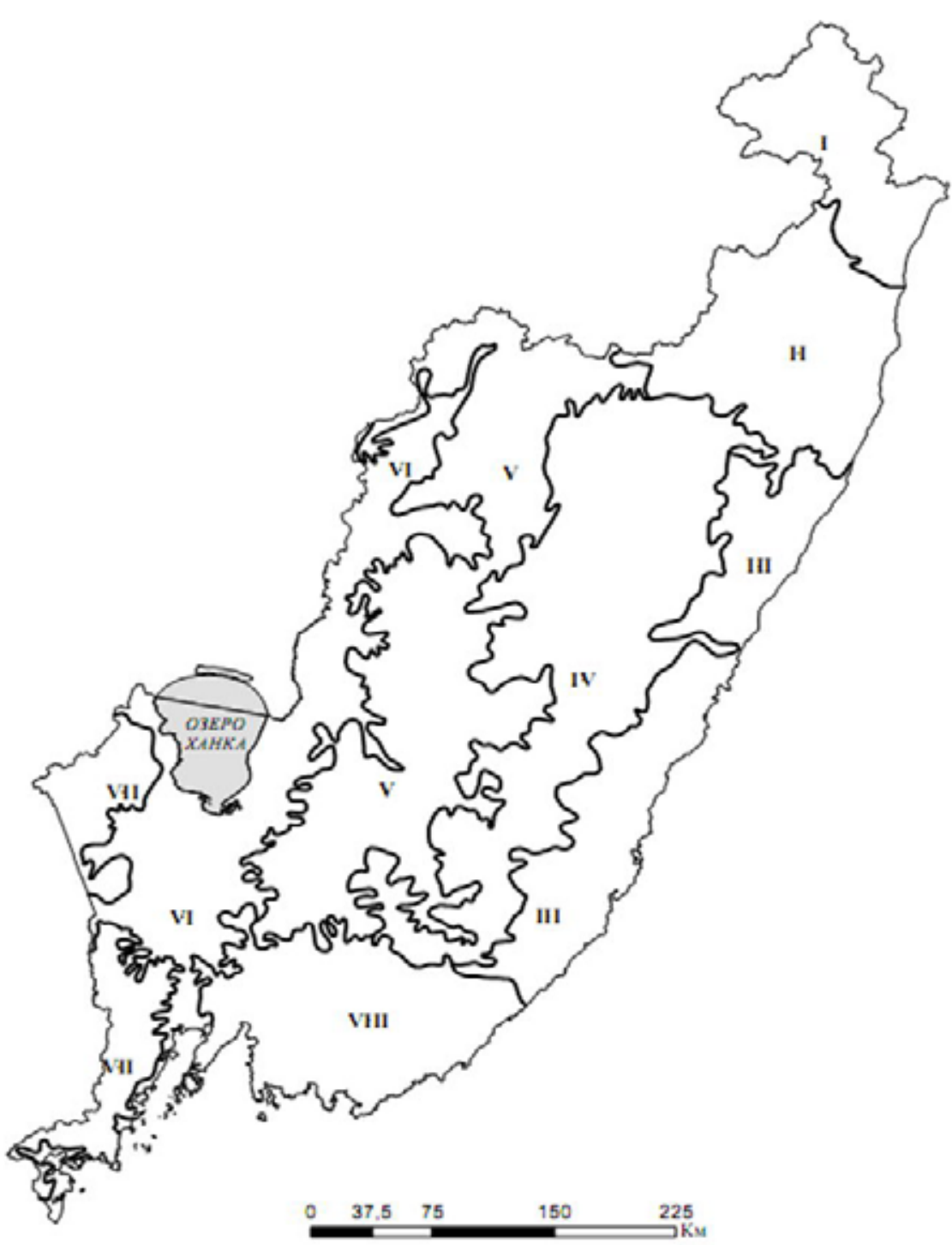

Puc. 1. Физико-географическое районирование [215]. Ландшафтные провинции Приморского края: I - Самаргинская,

II - Северо-Сихотэ-Алинская, III - Восточно-Сихотэ-Алинская,

IV - Центрально-Сихотэ-Алинская, V - Западно-Сихотэ-Алинская, VI - Западно-Приморская равнина, VI - Восточно-Маньчжурская, VIII - Южно-Приморская 
Фундамент Западно-Сихотэ-Алинской провинции, охватывающий верхнее течение р. Уссури, бассейны рек Арсеньевка, Крыловка, Быстрая, Маревка и среднее течение рек Малиновка Ореховка, Большая Уссурка, Бикин, по составу и структурнотектоническому положению сложный. Восточная часть сложена интенсивно тектонизированными палеозойско-мезозойскими алевролитово-кремнисто-вулканогенным, кремнисто-глинистым вулканогенно-кремнисто-алевролитовым, сланцевым вещественными комплексами Краевого Сихотэ-Алинского шва [197, 198, 200 (с. 13-14), 204 (с. 94-95)], эффузивными верхнемезозойскими породами кислого и основного состава. Западная часть провинции сложена верхнепалеозойско-мезозойским алевролитпесчаниковым вещественным комплексом, верхнепалеозойскими эффузивами кислого состава. Вещественные комплексы прорваны разновозрастными интрузиями кислого состава. Фундамент закрыт чехлом рыхлых полигенетических накоплений и залегает на глубине 2-20 м.

Центрально-Сихотэ-Алинская провинция, охватывающая наиболее возвышенную часть горного Сихотэ-Алиня от хр. Боголадза на севере до хр. Пржевальского на юге включительно, сложена преобладающими верхнемезозойскими алевролит-песчаниковым, песчаниково-алевролитовым вещественными комплексами, верхнемезозойскими эффузивами кислого, реже среднего, состава. Породы осадочных комплексов прорваны многочисленными интрузиями кислого состава. Фундамент закрыт чехлом рыхлых отложений и залегает на глубине до 10 м.

Фундамент Восточно-Сихотэ-Алинской провинции, расположенной на востоке Приморья и ограниченной береговой линией Японского моря, а на западе граница проходит вблизи водораздела Сихотэ-Алиня, представлен верхнемеловыми и палеогеновыми эффузивами Восточно-Сихотэ-Алинского вулканического пояса прорванными интрузиями различного состава. Среди вулканитов наблюдаются редкие «окна», сложенные кремнисто-карбонатнопесчаниково-алевролитовым вещественным комплексом. Фундамент закрыт чехлом рыхлых отложений и залегает на глубине до 5, 10 редко до $20 \mathrm{м}$

Фундамент Уссури-Ханкайской провинции, включающей оз. Ханка и Уссури-Ханкайскую равнину с бассейнами рек Мельгуновка, Комиссаровка, Илистая, Белая, среднее течение р. Уссури, нижнее течение р. Большая Уссурка и др., сложен палеозойскими сланцевым, гнейсово-сланцевым, сланцево-карбонатным, крем- нисто-карбонатным, алевролито-песчаниковым и гранитоидным вещественными комплексами. Фундамент перекрыт мощным чехлом четвертичных озерно-аллювиальных отложений и залегает на глубине до 110 м в районе оз. Ханка. В направлении от озера к внешним границам провинции глубина залегания уменьшается до $15-20 \mathrm{M}$

Фундамент Восточно-Маньчжурской провинции, расположенной в юго-западной части Приморья и охватывающей территорию от государственной границы на западе и севере до сочленения с Приханкайской равниной на востоке, сложен в центральной части базальтами Борисовского плато, в южной и северной частях провинции гранитоидами среднепалеозойского и верхнепермского возраста, эффузивами пермского возраста и верхнепермскими алевролит-песчаниковым, песчаниково-алевролитовым, сланцевым вещественными комплексами. Фундамент перекрыт чехлом рыхлых отложений мощностью от 2 до 20 м.

Фундамент Южно-Приморской провинции, расположенной в южной части Приморского края, в междуречье Киевки-Партизанской, сложен среднепалеозойскими метаморфическим, метагабброидным комплексами, прорванными гранитами зон активизации мелового возраста. На западе провинции развиты континентальные осадочные породы мелового возраста чехла и зон активизации Ханкайского массива алевролит-песчаникового, песчаниково-алевролитового, песчаниково-конгломератового вещественных комплексов. На востоке развиты алевролит-песчаниковый, вулканогенно-кремнисто-алевролитовый мезозойского возраста, эффузивный верхнемеловой кислого и среднего состава вещественные комплексы. Они прорваны верхнемеловыми интрузиями гранитов и гранодиоритов. Фундамент перекрыт чехлом рыхлых отложений и залегает на глубине от 2 до 20 м.

Наблюдается закономерное общее удревнение возраста фундамента с востока на запад и изменение состава и палеогеографических условий образований вещественных комплексов фундамента по структурно-тектоническим зонам: Восточно-Сихотэ-Алинский вулканический пояс, Восточная (зона Главного синклинория Сихотэ-Алиня), Краевой Сихотэ-Алинский офиолитовый шов (Главный антиклинорий Сихотэ-Алиня), активизации окраины Ханкайского массива, Ханкайский массив.

В восточной япономорской части Приморья в зоне окраинноконтинентального Восточно-Сихотэ-Алинского вулканического пояса развит фундамент верхнемелового-палеогенового возраста, 
континентальный, по составу вулканогенный. Среди вулканитов вулканического пояса наблюдаются «окна» палеозойско-верхнемезозойских морских и прибрежно-морских образований терригенного и вулканогенно-кремнисто-карбонатно-терриген-ного вещественных комплексов. Породы вулканического пояса прорваны многочисленными интрузиями гранитоидного состава.

В западнее расположенной от вулканического пояса Восточной зоне (зона Главного синклинория Сихотэ-Алиня) фундамент ландшафтов уже представлен верхнемезозойскими прибрежноморскими алевролит-песчаниковым и песчаниково-алевролитовым вещественными комплексами, прорванными интрузиями верхнемелового и палеогенового возраста.

В зоне Краевого Сихотэ-Алинского офиолитового шва - зоне коллизии [197, 198, 200 (с. 13-14), 203 (с. 43), 204 (с. 94-95)] фундамент представлен интенсивно тектонизированными окраинно-континентальными и морскими образованиями нескольких латерально неоднородных структурных этажей от среднепалеозойских до верхнемеловых преобладающего вулканогенно-кремнисто-карбонатно-терригенного вещественного комплекса.

В зоне активизации окраины Ханкайского массива в окраинно-континентальных прибрежно-морских и континентальных условиях, в наложенных прогибах и впадинах образовался верхнепермско-мезозойский фундамент, сложенный преимущественно алевролит-песчаниковым, песчаниково-алевролитовым вещественными комплексами.

Фундамент ландшафтов Ханкайского массива сложен наиболее древними по возрасту палеозойскими сланцевым, гнейсосланцевым, сланцево-карбонатным и другими вещественными комплексами.

Рыхлые отложения в ландшафтах. Фундамент ландшафтов Приморья перекрыт, как отмечалось выше, различающимися по мощности рыхлыми отложениями. Они сложно дифференцированы по родам ландшафтов (табл. 3) и разделяются на элювиальные, склоновые и аллювиальные. Их состав, структура, генезис, пространственная и временная дифференциация (кроме отмеченных вышеназванных публикаций) отражены в публикациях и материалах геолого-съемочных работ масштабов 1:50000 (фонды Примгеолкома).

Элювиальные отложения. Интенсивность процессов формирования элювия и мощность зоны гипергенеза определяются направленностью тектонических движений, геоморфологической
Соотношения генетических типов рыхлых накоплений по родам ландшафтов Приморского края (фрагмент)

\begin{tabular}{|c|c|c|c|c|c|c|c|c|}
\hline $\begin{array}{c}\text { Генетиче- } \\
\text { ский ряд } \\
\text { отложений }\end{array}$ & 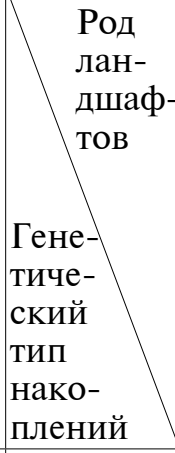 & 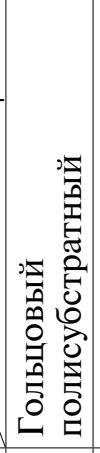 & 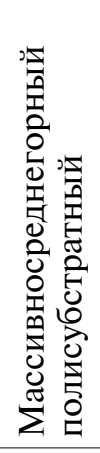 & 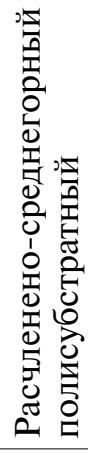 & 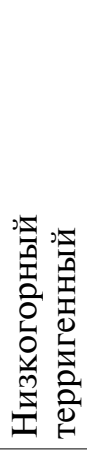 & 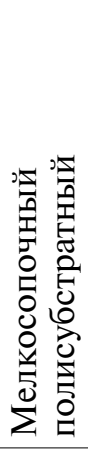 & 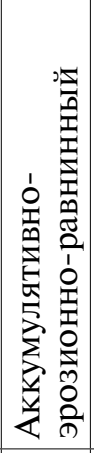 & 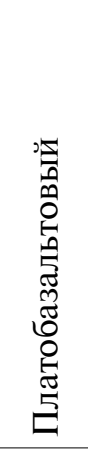 \\
\hline 1 & 2 & 3 & 4 & 5 & 6 & 7 & 8 & 9 \\
\hline \multirow[b]{2}{*}{$\begin{array}{l}\text { Элювиаль- } \\
\text { ный }\end{array}$} & $\begin{array}{l}\text { Обло- } \\
\text { мочный } \\
\text { элювий }\end{array}$ & +++ & ++ & + & + & - & - & - \\
\hline & $\begin{array}{l}\text { Сиалит- } \\
\text { но- } \\
\text { глини- } \\
\text { стый } \\
\text { элювий }\end{array}$ & & ++ & + & + & ++ & +++ & +++ \\
\hline \multirow{5}{*}{ Склоновый } & $\begin{array}{l}\text { Обваль- } \\
\text { ный }\end{array}$ & + & + & ++ & + & - & - & +++ \\
\hline & $\begin{array}{l}\text { Оползне- } \\
\text { вой }\end{array}$ & & & & & & & \\
\hline & $\begin{array}{l}\text { Солиф- } \\
\text { люцион- } \\
\text { ный } \\
\end{array}$ & +++ & ++ & ++ & + & - & - & + \\
\hline & $\begin{array}{l}\text { Курумо- } \\
\text { вый }\end{array}$ & ++ & ++ & ++ & + & - & - & + \\
\hline & Осыпной & +++ & +++ & +++ & ++ & + & - & ++ \\
\hline $\begin{array}{l}\text { Аллювиаль- } \\
\text { ный }\end{array}$ & \begin{tabular}{|l} 
Аллювий \\
равнин- \\
ных рек
\end{tabular} & - & - & - & - & - & ++ & - \\
\hline
\end{tabular}

- накопления отсутствуют либо встречаются очень редко.

+ распространены локально.

++ заметно распространены.

+++ распространены широко. 
позицией, климатическим режимом и составом фундамента каждого конкретного ландшафта. В пределах массивносреднегорного полисубстратного рода ландшафтов на залесенных уплощенных вершинах в процессе выветривания формируются суглинки и супеси с относительно малым количеством грубообломочного материала (дресвы, щебня). Несколько по-иному выглядит элювий гольцового полисубстратного рода ландшафтов, где, в силу отсутствия растительности, глубина сезонного промерзания грунтов значительно превышает мощность рыхлых накоплений. Здесъ верхняя часть суглинистого элювия бывает существенно обогащена грубообломочным материалом, механизм формирования которого связан с проявлением морозного выпучивания. Наиболее сильно процессы выветривания и химического преобразования материнских пород проявлены в пределах развития мощных зон линейной трещиноватости, сопровождаемых пропилитизацией, сульфидизацией, эпидотизацией, хлоритизацией и другими видами эндогенного минерального преобразования горных пород. Интенсивное развитие древних кор выветривания и глубокие химические преобразования отмечаются в зоне гидротермальных околорудных изменений в пределах рудных полей месторождений полезных ископаемых.

В пределах расчлененносреднегорного полисубстратного рода ландшафтов, где углы наклона поверхностей склонов достаточно велики, в настоящее время формируется грубообломочный щебенисто-глыбовый элювий мощностью 0,5-1,5 м. В редких случаях мощность его может достигать 3 м, т.е. быть больше глубины сезонного промерзания грунтов. Обычно такие мощности отложений отмечаются в седловинах и в зонах развития линейных кор выветривания. В описываемых условиях выветривания обломочный материал материнских пород с поверхности очень слабо изменен, что свидетельствует о быстром его обновлении в процессе формирования элювия. Характерной особенностью строения элювия зоны среднегорья является быстрая смена фаций. Среди наиболее характерных фаций по крупности материала можно назвать следующие: суглинисто-дресвяную, суглинистощебнистую, суглинисто-глыбовую, щебнистую, дресвянистую. По мере движения от зоны среднегорных полисубстратных родов ландшафтов к низкогорному терригенному и мелкосопочному полисубстратному для элювиальных накоплений характерны:

1. Большая выдержанность фациального состава по площади;

2. Увеличение мощности;
3. Более тонкий гранулометрический состав (вплоть до формирования существенно-глинистых фаций) .

Такое направление в изменении характеристик элювия определяется лучшими условиями сохранения рыхлого материала на месте его формирования и более интенсивным протеканием химического выветривания в условиях более теплого и влажного климата, в более благоприятных гидрологических и гидрогеологических условиях пониженной местности.

Коры выветривания площадного типа широко распространены в ландшафтах Уссури-Ханкайской равнины и мелкосопочного полисубстратного рода ландшафтов ее обрамления. Обычно это плотные, вязкие, жирные, лишенные слоистости бурые и буровато-коричневые глины. Под ними располагаются дезинтегрированные коренные породы. Элювиальные глины подобного типа прослеживаются вдоль крупнейших речных долин западного Сихотэ-Алиня. Мощность их всегда значительная (6-10 м и более)

Обширные по площади (около 40 тыс. кв. км) и значительной мощности элювиальные накопления картографируются в платобазальтовом роде ландшафтов. В условиях достаточно высокого испарения с поверхности избыточной влаги или ее быстрого просачивания в зону трещиноватых пород развиваются буроватокоричневые (шоколадные) глины с обломками базальтов, количество которых с глубиной увеличивается от 10-30\% до 80-90\% объема породы. Обломки базальта в пределах верхней метровой толщи глин обычно сильно выветрелые. В условиях переувлажнения (под верховыми болотами) элювий базальтов представлен серыми и темно-серыми глинами с меньшим количеством обломков сильно выветрелых базальтов, мощность элювия на базальтах обычно 1-6 м, на возвышенных плато до 30 м - в депрессионных понижениях.

Склоновые отложения ландшафтов. Обломочный материал этого ряда рыхлых отложений горного класса ландшафтов является преобладающим по объему. Разнообразие геологических, геоморфологических и природно-климатических обстановок объясняет значительную дифференциацию обломочного материала склонов по составу, крупности, сортировке, окатанности, выветрелости и способу перемещения. Среди склоновых отложений выделяются гравитационные и собственно склоновые. Среди гравитационных отложений ландшафтов в свою очередь выделяются обвальные, оползневые и осыпные. 
Обвальные отложения формируются при внезапном падении эрозионных останцов устойчивых к выветриванию скальных пород (столбов, башен, скальных гребней, стенок и т.п.) или при мгновенном отделении с первоначальным падением блоков (массивов) от вертикальных стенок отрыва на обрывистых участках склонов. Чаще всего обвалы приурочены к морскому побережью, кромке базальтовых плато, бортам эрозионных долин и крутым денудационным склонам. В современных условиях обычно отмечаются следы мелких и средних обвалов. Однако при их многократном повторении на склонах и у подножий накапливаются значительные по объему обвальные массы. Обвальные отложения зачастую формируются в тесной связи с другими отложениями склонового ряда, образуя пеструю мозаику в плане и причудливые, подчас трудно расшифровываемые, переслаивания в разрезе, ширина полосы обвальных отложений может достигать нескольких сотен метров, а мощность от единиц до десятков метров. По структуре они представляют собой хаотическую смесь глыб, щебня, дресвы, минерального мелкозема, остатков почвы и растительности. При быстром скатывании вниз по склону происходит сортировка обломочного материала по крупности, наиболее крупные глыбы накапливаются у подножий или на перегибах склонов. Такие отложения бывают практически лишены мелкозема в верхних горизонтах. Если на них и развиваются почвы, то они фрагментарные, сформированные за счет растительного опада.

На детальных аэрофотоснимках шлейфы обвально-осыпных, обвально-оползневых и т.п. отложений достаточно уверенно дешифрируются по формам микрорельефа и растительным ассоциациям. Растительность в зоне свежих обвалов бывает изрежена, на склоне много обломков стволов деревьев, ориентированных преимущественно вдоль склона.

Оползневые отложения горного класса ландшафтов распространены довольно широко. Зона развития оползней почти полностью совпадает с контурами платобазальтового рода ландшафтов, где иногда отмечаются оползневые блоки площадью до 2-3 кв. км с амплитудами перемещения до 100 м по вертикали, сохранившие первичную монолитность. В большинстве же случаев, благодаря пластическим деформациям пород, подстилающих базальты, последние дробятся на блоки и глыбы размером в первые метры. Довольно часто оползни развиваются в липарито-дацитовых породах мелового возраста, рыхлых и слаболитифицированных породах кайнозоя и современных рыхлых накоплениях склонов.
Отмечены единичные случаи оползания блоков скальных пород на морском побережье.

Оползневые отложения представлены обломочным несортированным материалом из хаотического нагромождения глыб скальных пород размером от первых дециметров до нескольких метров в поперечнике, промежутки между которыми заполнены щебнем и суглинком. Мощность этих отложений 1-3 м для поверхностных оползней (типа сплывов и оплывин) до 20-30 м и даже более (для оползней с захватом скальных пород). Мощность отложений возрастает на перегибах и у подножия склонов.

На местности оползневые отложения уверенно устанавливаются по характерным микроформам рельефа, а активные (свежие), кроме того, и по «пьяному лесу». Довольно обычны сложные смещения оползневых масс с делювиальными и осыпными склоновыми отложениями. В таких случаях обвально-осыпные, обвально-оползневые и т.п. отложения на аэрофотоснимках дешифрируются как единое поле полигенетических образований, дальнейшее расчленение которых затруднительно без детальных полевых исследований.

К осыпным склоновым отложениям относятся осыпи, россыпи, осовы, курумы и другие формы проявления структурных грунтов на вершинах и склонах гор. Их возникновение приурочено к участкам, где уничтожена растительность. В условиях контрастного климата почвенный покров на этих участках деградирует в результате активного проявления криогенного, гидрогенного крипа. Грубообломочный материал концентрируется в верхнем слое отложений.

Образование осыпей в настоящее время происходит преимущественно в среднегорьях на отметках выше 1000 м на юге и выше 600 м - на севере края. В эпохи похолоданий антропогена происходило заметное смещение зоны активного осыпеобразования в зону низкогорий (до отметок менее 100 м). С этим связано многочленное строение склоновых отложений $[14,36]$. В настоящее время осыпи зоны низкогорного полисубстратного и частично среднегорных полисубстратных родов ландшафтов, возникшие в холодные климатические эпохи, большей частью задернованы или даже перекрыты слоем делювиальных суглинков мощностью до 1 м. Мощность переслаивающихся осыпных и делювиальных накоплений в Сихотэ-Алине может достигать 30 м и более. В целом, в пределах западного макросклона Сихотэ-Алиня, особенно в южной его части, активные осыпи в зоне 
низкогорного терригенного рода ландшафтов наблюдаются только по бортам речных долин в местах эрозионных подмывов. Несколько активнее протекают процессы образования осыпей в зоне низкогорного вулканогенно-терригенного рода ландшафтов на восточном макросклоне, где более глубокое эрозионное расчленение, значительная крутизна склонов и морская абразия создают благоприятные условия для формирования осыпных накоплений.

Размеры осыпей самые различные: от первых квадратных метров до десятков квадратных километров. Пораженность осыпями некоторых территорий достигает $50 \%$ и более. Процессы формирования осыпей в последние годы значительно активизировались под влиянием антропогенного фактора.

Собственно склоновые отложения развиты на пологих и средней крутизны горных склонах. Среди них выделяется два наиболее распространенных типа отложений [97, 244 и др.]: щебнистодресвянистый и суглинистый. Щебнисто-дресвянистый является господствующим на склонах от уровня педиментных поверхностей до гребней водоразделов, исключая участки, занятые осыпными, оползневыми или обвальными отложениями. В низкогорьях щебнистые суглинки зачастую развиты лишь в верхних частях склонов, вблизи выходов коренных пород, ниже шлейфа обвально-осыпных отложений.

Нижняя часть разреза представлена щебнистыми суглинками с глыбами. Мощность этого слоя 1-3 м, реже до 5 м. Выше по разрезу на выположенных участках обычно залегают гумусированные суглинки с относительно меньшим содержанием грубообломочного материала, а на крутых склонах, наоборот, количество грубообломочного (щебенисто-дресвяного) материала значительно возрастает, вплоть до формирования «сыпунов», т.е. несвязных грунтов, лишенных мелкозема. Но, в отличие от осыпей, «сыпуны» сверху перекрыты слоем гумусированных почв. Мощность этого слоя 0,5-1,5 м. Местами наибольшего накопления щебнисто-дресвянистых отложений являются всякого рода отрицательные перегибы и нижние части полого-вогнутых склонов. Самые большие мощности (до 20 м) отмечаются в шовной части древних речных террас.

Гранулометрический состав отложений в сходных природно-климатических условиях зависит от крутизны поверхности накопления и вещественного состав подстилающих коренных пород, поскольку зона формирования обломочного материала и зона его аккумуляции располагаются в пределах единого склона. Суглинистый тип отложений распространен в мелкосопочных полисубстратных и низкогорных терригенных и вулканогеннотерригенных ландшафтах Сихотэ-Алинской и Восточно-Маньчжурской и в эрозионно-аккумулятивно-равнинных ландшафтах Уссури-Ханкайской физико-географических областей.

В целом толща покровных суглинков, глин и супесей (за пределами долин водотоков) по своему происхождению, в зависимости от привязки к определенным формам рельефа, относится к элювиально-делювиальным, делювиальным, делювиально-пролювиальным или делювиально-аллювиальным отложениям. В зоне мелкосопочного полисубстратного рода ландшафтов (УссуриХанкайская равнина) мощность толщи суглинков вместе с корой выветривания достигает 60 м (из них «бурых» суглинков не менее 15-20 м). В зоне мелкосопочного полисубстратного рода ландшафтов, где процессы денудации менее активны, мощность горизонта суглинков уменьшается до 8-10 м, а в пределах низкогорного терригенного рода редко бывает больше 6 м.

Аллювиальные отложения и их особенности детально рассмотрены в фондовой и изданной литературе (фондовые материалы геолого-съемочных работ масштаба 1:50 000; [96, 97 и др.]). Они доминируют в покрове эрозионно-аккумулятивных равнинных и долинно-речных ландшафтов.

Общим признаком формирования накоплений долин является слабое поступление в долину рыхлого материала с прилегающих участков склонов. В разрезах преобладает материал отложений, претерпевших дальнюю транспортировку и сильную переработку (физическую и химическую) .

Среди аллювиальных отложений отчетливо выделяется русловая, пойменная и старичная фации. Русловая фация представлена, преимущественно, песчано-галечниковыми накоплениями по рекам Бикин, Большая Уссурка, Уссури, Раздольная (на участках от государственной границы до устья р. Раковка), их крупным притокам и всем рекам Япономорского макросклона. В русле нижней части р. Раздольная и в руслах всех рек бассейна оз. Ханка в составе русловой фации преобладают алеврито-псаммитовые фракции. Значительным развитием в долинах пользуются озерные, озерно-болотные и болотные накопления.

Мощность аллювия пойменной фации на крупных реках (Уссури, Большая Уссурка, Бикин) достигает 10 м, у других рек редко превышает 6 м. Что касается накоплений террас рек, то следует 
отметить их полигенетический характер, пестроту разрезов вкрест и по простиранию долин.

Региональная эволюция фундамента и рубежные режимы развития ландшафтов. Для современного понимания с позиции ландшафтной географии качественной определенности фундамента и его значимости в ландшафтной компонентной специфике ландшафтных геосистем разноранговых динамических геосистем Приморского регионального звена необходимо рассматривать его на фоне общей палеогеографической эволюции значительно большего пространства, с учетом своеобразия континентальноокеанической дихотомии, закона фундаментального дуализма суши и моря. Эволюция фундамента ландшафтов на примере Сихотэ-Алиня, Сахалина, Хоккайдо и прилегающих областей, определяющая важнейшие черты палеогеографии и последующего разделения на физико-географические страны и провинции, разделяется на два генеральных этапа: аккреционный и постаккреционный [197, 198, 200, 203, 204, 207, 222]. Аккреционный отвечает аккреции геолого-структурных подразделений Тихоокеанской палеоплиты к палеоконтинету (рис. 2) [200, 204, 207, 222]).

Фациальный анализ, сравнение состава и возраста стратифицированных меланжевых комплексов, тектоники и магматических парагенезисов показывает, что в рассматриваемой зоне аккреция происходит дважды. Первая соответствует аккреции в домеловое время Приморского палеоплато к активной окраине Ханкайского массива в Приморье (и далее на север к окраине), представленной океаническими и шельфовыми образованиями - основания Бикино-Байджальской зоны. Палеоплато представляет собой положительное геолого-структурное подразделение Тихоокеанской палеоплиты и если сравнивать с современными плато, оно имело некоторые особенности.

Палеогеографический анализ среднепалеозойско-кайнозойских вещественных комплексов Сихотэ-Алиня, островов Сахалин и Хоккайдо, геофизические материалы и суммарная мощность толщ показывает, что Приморское палеоплато имело увеличенную мощность коры, около 20 км. На плато существовали вулканические острова, поднимались отдельные вершины, часть которых несло атоллы и рифы, блоки, глыбы и обломки которых сейчас наблюдаются в вещественных комплексах Краевого Сихотэ-Алинского офиолитового шва, Ковалеровском, Ольгинском, Дальнегорском выступах фундамента Сихотэ-Алиня, а также островов
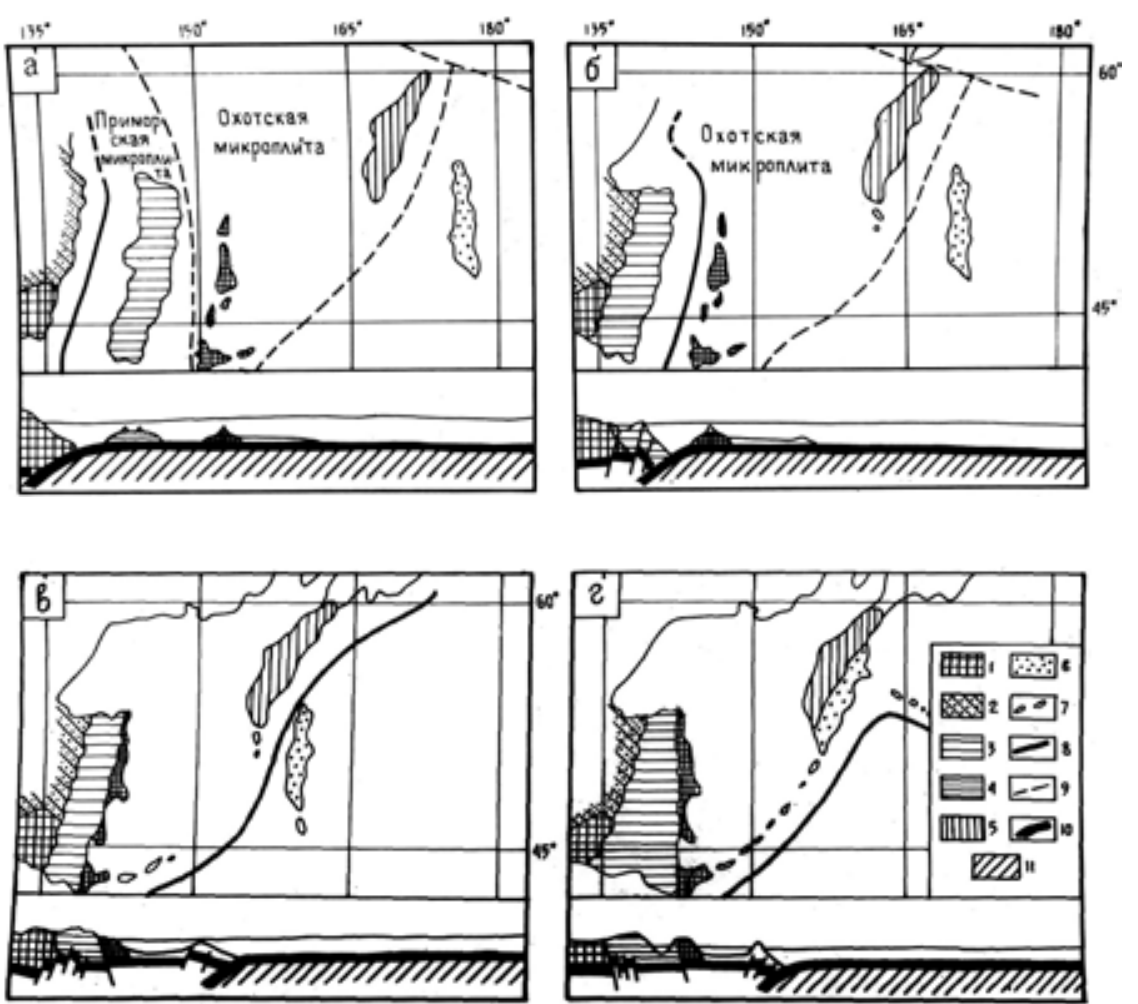

Puc. 2. Схема положения основных палеоструктур и сопряженных с ними элементов зоны перехода северо-востока Азии к Тихоокеанской плите.

1 - Ханкайский массив. 2 - пассивная палеоокраина Бикино-БаджалоНижнеамурской зоны. 3 - Приморское палеоплато Приморской микроплиты с атоллами и рифовыми постройками на вершинах гор. 4 - Хоккайдо-Сахалинский палеохребет юго-западной части Охотской микроплиты с атоллами и рифовыми постройками на вершинах гор. 5 - Западно-Камчатское поднятие. 6 - Восточно-Камчатское поднятие. 7 - современная вулканическая дуга. 8 - сейсмофокальная зона. 9 - предпологаемые границы микроплит. 10 - океаническая кора. 11 - мантия в океане.

$a, \sigma, в$, г - положение палеоструктур в:

$a$ - домеловое время, $\sigma$ - бериасе, $в$ - валанжин-датское время, г - в палеоцен-эоцене 
Сахалин и Хоккайдо. Аккреция сопровождалась формированием тектонических зон спаяния. Они характеризуются интенсивной тектонизацией слагающих их вещественных комплексов. В их пределах совмещены фрагменты полигенетических образований окраины палеоконтинента, Приморского палеоплато, офиолиты и тектонически состыкованы образования нескольких латерально неоднородных структурных этажей - от среднепалеозойских до верхнемеловых. Зона спаяния в современном эрозионном срезе наиболее выражена в Приморье и ее передовая часть отвечает сквозной структуре Главного и Партизанского антиклинориев, которую ранее мы назвали Краевым Сихотэ-Алинским офиолитовым швом. Далее на севере Хабаровского края зона спаяния чаще перекрыта чехлом меловых комплексов и несколько ярче проявляется в районе Шантарских островов. Предлагается, что спаяние Приморского палеоплато сопровождалось отмиранием существовавшей вдоль активной окраины палеоконтинента сейсмофокальной зоны и ее миграцией в тыловую часть палеоплато, которая далее развивалась в геодинамическом режиме активной окраины.

Второй этап аккреции отвечает аккреции в докайнозойское время к сформировавшейся в меловое время активной окраине (восточная окраина Приморского палеоплато) более молодых геолого-структурных подразделений Тихоокеанской плиты.

Постаккреционный этап характеризуется дальнейшим «созреванием» (континентализацией) соответствующих нарастивших континент микроплит. «Созревание» сопровождалось гранитизацией и в том числе наиболее молодых в регионе офиолитов о. Сахалин. В Пионерско-Шельтингской зоне Восточно-Сахалинских гор установлены гранитизированные габброиды габброидных уровней офиолитов (гранитизированный метагабброидный парагенезис). Более интенсивно гранитизированы среднепалеозойские Партизанско-Киевские метагабброиды. Эти данные указывают на вполне закономерно неоднородно протекающий процесс гранитизации наростивших континент микроплит. Постаккреционный этап характеризуется также формированием отличающегося по возрасту, составу, мощности чехла, уже ставших фундаментом микроплит. В южном Сихотэ-Алине чехол представлен несколько километровыми меловыми терригенными, часто малассоидными толщами Главного синклинория, на о. Сахалин кайнозойскими полифациальными вещественными комплексами и т.д. Континентализация, сопровождающаяся формированием складчатых горных, предгорных и равнинных областей, предопределила рубежные особенности формирования ландшафтов и геосистем.

Определяющим в формировании фундамента, кайнозойских и современных ландшафтов и геосистем (в частности, закартированных автором в масштабе 1:500000 в Приморском крае) является нижнекайнозойский режим континентализации территории. Этот режим разделил данную территорию на платформенную равнинно-рифтогенную Уссури-Ханкайскую область и горную складчатую Сихотэ-Алинскую, сформировавшуюся как результат мезозойской аккреции к палеозойской активной окраине Ханкайского массива палеоокеанического плато и его континентализации.

Отмеченная направленность (палеоокеаническое плато - его чехол - континент) сопровождалась сменой климата от морского к муссонному, в условиях которого и развиваются современные ландшафтные геосистемы. Кроме того, на большей территории края сложился определяющий в формировании ландшафтов коренной фундамент, представляющий собой в современном эрозионно-денудационном срезе сложной агломерат состыкованных между собой аккрекриционных и постаккреционных вещественных комплексов структурных зон континентальной, субконтинентальной, субокеанической и океанической кор. Однако, региональный кайнозойский тектонический режим не привел к одновременной континентализации рассматриваемой территории. Если в горных складчатых Сихотэ-Алинской и Восточно-Манчжурской физико-географических областях континентальные условия существуют с начала кайнозойского по современное время, то в Уссури-Ханкайской области устанавливается локальный флуктуационный тектонический режим поднятий и опусканий, развивающийся в условиях рифтогенеза этой территории. И только к неоген-четвертичному времени, в связи с осушением территории, устанавливается континентальный режим и в его физико-географических условиях начинают формироваться современные равнинные с различными типами почв ландшафты (88, 89 и другие виды и 88-1 местности (ландшафты). 88 - здесь и далее номера местностей (ландшафтов) на карте ландшафтов Приморского края [243] и объяснительной книге к ней [244]). Не исключается возможность, что на палеогеновых и неогеновых поднятиях Уссури-Ханкайских территорий могли уже развиваться континентальные ландшафты и при полевых 
исследованиях можно среди современных встретить локальные реликтовые участки.

Особое влияние на формирование и эволюцию фундамента горно-таежных и горно-лесных кайнозойских ландшафтов оказали региональные палеогеновые и неогеновые режимы рифтогенной активизации коренного фундамента. Активизации приводили к формированию рифтогенных зон, сопровождающихся грабено- и горстообразованием. Образование сложных грабенов на территории края хорошо фиксируются контрастным базитовым магматизмом. Его продуктами сложены многочисленные базальтовые плато (Шкотовское, Борисовское, Зевинское, Единское, Иссиминское, Бикинское и другие). Влияние режима зон активизации на развитие ландшафтов двоякое. Первое привело к сокращению площади горно-таежных, горно-лесных ландшафтов за счет их вытеснения продуктами базитового магматизма. Второе - на базитовом фундаменте базальтовых плато формировались молодые горно-темнохвойные (5 - номер вида по карте) и горно-лесные (44-54 - номера видов по карте) ландшафты.

Континентализация территории края не привела к стабилизации тектонических движений. До сегодняшнего дня устанавливается флуктуационный тектонический режим дифференцированных во времени и пространстве горст-грабеновых поднятий и опусканий фундамента ландшафтов. Флуктуационные поднятия и опускания территорий края по разному отразились на происходившем развитии ландшафтов. В частности, в четвертичном периоде в центральном Сихотэ-Алине на водоразделе рек Бикин, Бол. Уссурка и рек Япономорского макросклона поднятия привели к усилению континентализации климата, развитию процессов солифлюкции, курумового, термокрипового и криокрипового транзита грубообломочного материала, к формированию оттеснивших горно-темнохвойные горно-тундровых ландшафтов.

\section{2 Рельеф}

Рельеф как компонент ландшафта играет значимую роль в формировании и развитии структуры и в пространственной организации ландшафтов и определяет его многие особенности, прежде всего зависящие от горизонтального и высотного расчленения территории. Имеет значение высотная поясность климата, инсоляция склонов, смена растительных поясов, почв и т.д. Рельеф в значительной степени определяет форму и размеры контуров ландшафтов, соотношение между миграцией вещества во взвешенном и растворенном состоянии, влияет на скорость водообмена в ландшафте. На территории Приморья получили развитие различные типы рельефа: гольцы, среднегорье массивное и расчлененное, низкогорье, мелкосопочник, равнинные поверхности разного генезиса.

Гольцы и подгольцовые горы. В большинстве случаев это самые возвышенные участки гор (выше границы хвойного леса), имеющие округлые вершины и террасированные склоны. Они либо совершенно лишены древесно-кустарниковой растительности (гольцовая тундра), либо покрыты кедровым стлаником или каменной березой (каменноберезовое криволесье). На севере Приморья на Сихотэ-Алине гольцовый и подгольцовый рельеф довольно часто отмечается уже с отметок 700-900 м, на юге - редко опускается ниже 1100 м. Наиболее обширные участки его наблюдаются на водоразделах рек Бикин, Большая Уссурка, в верховьях р. Уссури и по водоразделам рек Япономорского макросклона. К этому же рельефу близко стоят лишенные всякой растительности и даже почвенного покрова каменистые россыпи, осыпи, курумы и каменные потоки, приуроченные к гребням водоразделов, вершинам и склонам гор.

Среднегорный рельеф. К этому типу рельефа отнесены горные сооружения Сихотэ-Алиня и Восточно-Маньчжурского нагорья, имеющие абсолютные отметки выше 800 м и относительные превышения более 600 м. По степени эрозионного расчленения среднегорье делится на массивное и расчлененное. Среднегорье массивное характеризуется преобладанием наиболее возвышенных куполовидных массивов и линейно вытянутых горных кряжей. В пределах массивного среднегорья распространены вершины округлых очертаний и уплощенные широкие водораздельные территории. Наибольшие площади массивного среднегорья приурочены к центральному Сихотэ-Алиню, они расположились на водоразделах Бикина, Большой Уссурки и Уссури. На Япономорском макросклоне значительные участки массивного среднегорного рельефа обрамляют бассейны рек Самарга, Максимовка, Кема, Серебрянка, Киевка.

Среднегорье расчлененное, в отличие от среднегорья массивного, характеризуется разделением первоначально единых массивов на большое число узких извилистых хребтов и обособленных вершин с глубоко расчлененными склонами. Среднегорье этого типа занимает большую часть Япономорского макросклона и ши- 
роко распространено в Центральном Сихоте-Алине. Интенсивно расчлененный среднегорный рельеф развит в районах с весьма разнообразным геологическим строением, что накладывает отпечаток на развитие тех или иных мезо- и микроформ. Но общими признаками являются резкая очерченность водораздельных гребней, очень крутые прямые или выпуклые в верхней части склоны. Именно к полосе такого контрастного рельефа приурочены широко наблюдаемые на Япономорском макросклоне подвижные осыпи, часто покрывающие склоны от подножия до водораздела (вершины) .

Низкогорный рельеф - это горные сооружения Сихотэ-Алиня и Восточно-Маньчжурского нагорья с абсолютными высотами 300-800 м и относительными превышениями до 200-250 м. По контрастности элементов (крутизна склонов, четкость водораздельных гребней и эрозионных долин) низкогорье весьма сходно с интенсивно расчлененным среднегорьем. Для него характерны прямые, реже выпуклые, склоны, покрытые довольно значительным слоем щебенистых суглинков, мощность которых у подножий гор обычно увеличивается. Обнажения отмечаются редко.

Мелкосопочный рельеф обрамляет Уссури-Ханкайскую равнину и имеет абсолютные отметки менее 300 м. Характерными формами этого типа рельефа являются отдельно стоящие возвышенности, или гряды (местное название «сопки»), разделенные аккумулятивными долинами. Характерной чертой возвышенностей является различная крутизна верхней (15-20) и нижней (3-4) частей склонов. Это объясняется широким распространением в пределах мелкосопочника педиментных поверхностей, сложенных полигенетическими накоплениями. Это преимущественно глины, представляющие собой типичный делювий, перемежающийся в разрезе и по площади с накоплениями логов, балок, эрозионных борозд, рытвин, временных потоков.

Равнинный рельеф развит на территории Уссури-Ханкайской равнины, охватывая бассейны рек Мельгуновка, Комиссаровка, Илистая, Белая, нижнее течение р. Большая Уссурка, среднее течение р. Раздольная и др. Центральную часть ее занимает Приханкайская низменность, по периферии которой расположены слаборасчлененные террасы нижнечетвертичного, средне и верхнечетвертичного возраста, современные террасы. Среди равнины возвышаются отдельные останцовые сопки и мелкогорные возвышенности.

\section{Контрольные вопросы}

1. Раскройте понятие фундамент ландшафта.

2. Какую роль в ландшафте имеет фундамент?

3. Какие материалы использовались при изучении фундамента ландшафтов Приморья?

4. Какие комплексы выделены в фундаменте и по какой методике это сделано?

5. Сколько выделено вещественных комплексов?

6. Раскройте роль рыхлых отложений в ландшафте.

7. Рассмотрите классификацию рыхлых отложений.

8. Раскройте общие закономерности распространенности вещественных комплексов по провинциям Приморья.

9. Охарактеризуйте распределение элювиальных отложений в ландшафтах.

10. Охарактеризуйте распределение склоновых отложений в ландшафтах.

11. Охарактеризуйте распределение аллювиальных отложений в ландшафтах.

12. Назовите и дайте характеристику основных особенностей эволюции фундамента и рубежных режимов развития ландшафтов.

13. Какую общую роль играет рельеф как компонент ландшафта?

14. Какие типы рельефа получили развитие в Приморье и дайте их общую характеристику? 


\section{Лекция 5}

\section{РЕГИОНАЛЬНАЯ ПРИРОДНО-КОМПОНЕНТНАЯ СПЕЦИФИКА ПРИМОРЬЯ (кЛимаТ)}

Вся территория Приморского края располагается в муссонной климатической области умеренного пояса. Ее климатические особенности определяются в первую очередь муссонным характером циркуляции, являющейся существенным фактором континентально-океанической дихотомии. Поздней осенью и зимой она находится под преобладающим воздействием очень холодных и сухих воздушных масс, формирующихся в области очень мощного азиатского антициклона. Доминирующий поток воздуха направлен с северо-запада на юго-восток - к области более низкого давления, располагающейся над Тихим океаном. В этот период наблюдается преимущественно ясная морозная погода.

В теплый период преобладает циркуляция обратного направления. Юго-восточные ветры поздней весной и ранним летом приносят относительно прохладный и влажный морской воздух, вызывающий образование туманов, слоистых облаков и моросящие дожди. Во второй половине лета на континент вторгаются массы очень влажного теплого воздуха из южных широт. Эти вторжения сопровождаются дождями большой продолжительности и интенсивности.

Следует подчеркнуть, что континентальный режим в климате края в течение года существует 7-8 месяцев. Годовые амплитуды, характеризующие континентальность климата, к побережью Тихого океана уменьшаются, но остаются достаточно высокими. Так, на побережье амплитуды составляют $30-34^{\circ}$, а на остальной территории Приморского края $-35-45^{\circ}$. Этим Приморье резко выделяется среди других прибрежных регионов России, расположенных на тех же широтах. Климат края значительно суровее чем в районах Европейской части России, лежащих на той же широте. В Приморье средние годовые температуры на 6-8 , а зимой на $12-15^{\circ}$ ниже, чем на Черноморском побережье Кавказа, в Крыму, на юге Украины и в Средней Азии. Считается [115], что по температурному режиму и облачности в зимнее время, по активному испарению снега при отрицательных температуpax и т.п. территория края, особенно резко преобладающий по площади ее равнинно- низкогорный западный район, сравнимы с некоторыми сугубо континентальными районами Забайкалья.

Но в целом для Приморского края характерен гумидный климат фреатического типа, т.е. климат, в котором осадки превышают испарение, а избыток воды удаляется поверхностным стоком с частичным просачиванием в почву для формирования грунтового потока питания подземных вод глубокой циркуляции, что является существенным фактором функционирования ландшафтов.

Географическое положение территории Приморского края на стыке огромного материка Евразии с обширными водными пространствами Тихого океана, неоднородность поверхности и значительная вытянутость в меридиональном направлении обусловливают большую дифференциацию климатических условий по отдельным его районам [27, 49, и др.]

Солнечная радиация определяет величину инсоляции земной поверхности, которая в свою очередь зависит от инсоляционной экспозиции, т.е. положения поверхности по отношению к странам света и плоскости горизонта. Инсоляционная экспозиция определяет интенсивность облучения поверхности солнечными лучами в данной местности и для данного времени года. Разная инсоляционная экспозиция обуславливает дифференциацию климатов, различия в характере почв, растительности, кор выветривания, типов выветривания. Кроме того, она существенным образом влияет на скорость мобилизации и перемещения рыхлого обломочного материала.

Солнечная радиация, поступающая на земную поверхность, является одним из основных климатообразующих факторов. В свою очередь она в значительной степени зависит от циркуляции атмосферы (что проявляется через облачность и прозрачность) и особенностей земной поверхности (высота над уровнем моря, экспозиции, закрытости горизонта, альбедо поверхности).

Особенности радиационного режима ландшафтов Приморского края определяются муссонным характером циркуляции. В зимний период поступление прямой солнечной радиации повсеместно в крае составляет $50-70 \%$ от возможных сумм, летом она снижается до $40-55 \%$ за счет туманов и значительной пасмурности. 
Годовой приход прямой солнечной радиации на горизонтальную поверхность при ясном небе (т.е. теоретически возможный приход) составляет 140 ккал/см² на юге и 133 ккал/ $\mathrm{cm}^{2}$ на севере края [188]. Годовые суммы рассеянной радиации при безоблачном (ясном) небе для большинства районов края составляют 29-30 ккал/см². Для района г. Владивосток они несколько выше - 33 ккал/см². Как известно, облачность снижает поступление прямой солнечной радиации на 50-60\% и в то же время увеличивает рассеянную радиацию более чем в полтора раза. В результате при реальных условиях облачности годовой приход суммарной радиации колеблется в пределах 110-120 ккал/ $\mathrm{cm}^{2}$. При этом увеличение сумм радиации с севера на юг незначительное и прослеживается только в континентальной части края. В значительно большей степени наблюдается уменьшение в прибрежных районах. Например, во Владивостоке годовая сумма суммарной радиации 112 ккал/см², а на ГМС Новосельское в 200 км на ССВ - 118 ккал/см². Большое влияние на количество приходящей радиации, особенно на побережье, оказывают местные условия. Так, на ГМС Садгород, находящейся всего в 20 км от ГМС Владивосток, годовой приход суммарной радиации больше на 8 ккал/см ${ }^{2}[188]$.

В годовом ходе максимум месячных сумм суммарной и прямой радиации на горизонтальную поверхность для континентальных районов края приходится на июнь (14-15 ккал/см ${ }^{2}-$ суммарная и 7-9 ккал/см² - прямая). На побережье из-за пасмурной погоды наблюдается максимум сумм прямой солнечной радиации на горизонтальную поверхность в марте - мае - 7-7 ккал/см и сентябре $-6-7$ ккал/см².

Минимальный приход радиации повсеместно наблюдается в декабре (4-5 ккал/см ${ }^{2}$ суммарная и 2-3 ккал/см² - прямая, несколько убывая с юга на север).

Температурный режим ландшафтов Приморского края определяется в основном характером циркуляции атмосферы и рельефом. Влияние географической широты незначительно. Муссонная циркуляция создает зимой и летом более низкие температуры, чем на тех же широтах на западе нашей страны. Так, средняя годовая температура воздуха на ГМС Тимирязевский (г. Уссурийск) +2,60 а в расположенном на той же широте г. Сочи $+14^{\circ}$ [185-192]. Значительные различия в температурном режиме существуют и внутри края. Средняя годовая температура в самом северном пункте побережья (ГМС Золотой) составляет $1,9^{\circ}$, а в самом южном (ГМС Гамов) 5,6 (градиент 3,7²). На Уссури-Ханкайской равнине градиент среднегодовой температуры по широте около $1^{\mathrm{o}}$ на 100 км, что вдвое выше Европейской части России и Сибири. Особенно велик этот градиент зимой, когда он достигает $2,3^{\circ}$ на 100 км, а на последних 100 км от г. Уссурийск до г. Владивосток даже $6,8^{\circ}$, что является уникальной особенностью климата Приморского края [185-191].

В зимнее время года (с декабря по февраль) средняя месячная температура воздуха на побережье края от м. Гамова до м. Поворотный $-9,3^{\circ}$, от бух. Валентин до м. Золотой $-10,3^{\circ}$; на восточном предгорье Сихоте-Алиня (от ГМС Агзу до ГМС Бетка) $-14,4^{\circ}$; на Уссури-Ханкайской равнине $-17,2^{\circ}$; на западном предгорье $-20,5^{\circ}$. Повышение значений зимних температур на побережье Японского моря объясняется не только экранирующей ролью Сихотэ-Алиня в отношении зимних муссонных потоков и отепляющим влиянием моря, но и наличием здесь феновых процессов, при которых ветры, дующие с гор в сторону моря, в отдельные дни значительно повышают температуру воздуха. Именно поэтому наименее холодными в зимнее время являются южное и восточное побережья края.

Самым холодным месяцем во всем крае является январь. Наиболее низкая среднемесячная температура января $\left(-22^{\circ} \ldots-26^{\circ}\right)$ отмечается во внутренних районах края (на западных предгорьях и на вершинах гор). Самая низкая из возможных температур, наблюдавшихся в отдельные годы (абсолютный минимум), отмечена в долинах между западными отрогами Сихотэ-Алиня на ГМС Глубинное $-54^{\circ}$, ГМС Красный Яр и Вострецово $-51^{\circ}$. Самые низкие отрицательные температуры на вершинах Сихотэ-Алиня $-42^{\circ} \ldots-44^{\circ}$, в пределах среднегорных полисубстратных родов ландшафтов и Уссури-Ханкайской равнины $-37^{\circ} \ldots-50^{\circ}$, на восточном побережье $-34^{\circ} \ldots-38^{\circ}$, на юге края (район г. Находка) $-27^{\circ} . .-28^{\circ}$, ГМС Владивосток, порт $-31^{\circ}$, ГМС Садгород $-40^{\circ}$. Столь низкие для данных широт температуры обусловлены поступлением холодных масс воздуха из Центральной Азии и глубоким выхолаживанием приземного слоя в ночные часы при безоблачном небе над территорией Приморья. Решающая роль в распределении зимних температур в крае принадлежит центральному водоразделу горной страны Сихотэ-Алинь. Он является естественной климатической границей между восточным и западным макросклонами. Водораздельный гребень препятствует свободному стоку приземного слоя холодного воздуха с континента на море. Исключительно широко 
ной температурной инверсии. Обычно в ночное время, при отсутствии ветра, в котловинах между горными отрогами в результате застоя воздушных масс и активной потери тепла на излучение при ясном небе возникают участки переохлаждения (инверсионные очаги), внутри которых у поверхности земли температура воздуха опускается до $-45^{\circ} \ldots-50^{\circ}$ и ниже.

В теплый период года температура воздуха распределяется по территории края довольно своеобразно. Средняя температура лета с июня по август на побережье зал. Петра Великого 15-18 восточном побережье $13-16^{\circ}$, на восточном макросклоне СихотэАлиня $13-17^{\circ}$, на западном макросклоне $16-19^{\circ}$, на вершинах гор $11-16^{\circ}$, на Уссури-Ханкайской равнине $18-20^{\circ}$.

Весьма важной характеристикой условий теплого времени года служат суммы температур за периоды с температурой выше определенных пределов. Они хорошо выражают ресурсы тепла, определяемые радиационным и тепловым балансом данной территории (табл. 4).

Заметно значительное повышение средней температуры от береговой полосы вглубь территории, хотя горизонтальный градиент значительно слабее, чем зимой, и составляет лишь десятые доли градуса на 100 км (наибольшее значение на линии Уссурийск Владивосток: 0,90 на 100 км).

Периоды со средней суточной температурой выше $10^{\circ}$, благоприятной для проведения природопользовательских, экологических и других экспедиционных работ, наблюдаются на всей территории края ежегодно. Продолжительность их составляет от 2-4 мес. в низкогорных вулканогенно-терригенных и терригенных и среднегорных полисубстратных родах ландшафтов, горного класса ландшафтов Сихотэ-Алиня, на побережье Японского моря; до 5 мес на Уссури-Ханкайской равнине и на побережье зал. Петра Великого.

Абсолютные максимальные температуры воздуха в летний период изменяются по территории края от $32^{\circ}$ до $41^{\circ}$ (рис. 3).

Наступление последних заморозков весной, первых заморозков осенью отличается большим разнообразием. Период, в течение которого прекращаются последние весенние заморозки, растягивается по территории края с юга на север на 2 мес (с 13 апреля по 14 июня включительно). Наступление первых заморозков осенью происходит в обратном порядке, но только более интенсивно (в течение 1,5 мес. морозами охватывается вся территория края)
Распределение сумм положительных средних суточных температур воздуха по различным физико-географическим районам Приморского края (составлена автором по [185-192]).

\begin{tabular}{|c|c|c|c|c|c|}
\hline \multirow{2}{*}{$\begin{array}{c}\text { Район и название метеостанции, } \\
\text { по которой приведены табличные } \\
\text { данные }\end{array}$} & \multicolumn{5}{|c|}{$\begin{array}{c}\text { Сумма температур за периоды } \\
\text { с температурой выше: }\end{array}$} \\
\hline & $0^{\circ}$ & $5^{\circ}$ & $10^{\circ}$ & $15^{\circ}$ & $20^{\circ}$ \\
\hline Побережье залива Петра Великого & & & & & \\
\hline $\begin{array}{l}\text { Сев. часть (Владивосток) } \\
\text { Южн. часть (Посьет) }\end{array}$ & $\begin{array}{l}2830 \\
2922\end{array}$ & $\begin{array}{l}2740 \\
2831\end{array}$ & $\begin{array}{l}2459 \\
2452\end{array}$ & $\begin{array}{l}1712 \\
1727\end{array}$ & $\begin{array}{l}753 \\
701\end{array}$ \\
\hline \multicolumn{6}{|l|}{ Побережье Японского моря } \\
\hline Сев. часть (Сосуново) & 1938 & 1778 & 1386 & 644 & 0 \\
\hline Южн.часть (Валентин) & 2596 & 2465 & 1995 & 1305 & 0 \\
\hline \multicolumn{6}{|l|}{ Западно-Приморская равнина } \\
\hline Сев. часть (Дальнереченск) & 2799 & 2720 & 2438 & 1840 & 940 \\
\hline (Спасск-Дальний) & 3042 & 2965 & 2679 & 2095 & 1234 \\
\hline Южн & 2906 & 2836 & 2526 & 1858 & 928 \\
\hline Борисовское плато (Полковница) & 2379 & 2287 & 1924 & 1185 & 0 \\
\hline \multicolumn{6}{|l|}{ Восточный макросклон } \\
\hline Сев. & 2161 & 2059 & 1676 & 1127 & 0 \\
\hline (Черем & 2344 & 2236 & 1860 & 1202 & 0 \\
\hline Южн. часть (Ветка) & 2570 & 2165 & 2072 & 1352 & 0 \\
\hline \multicolumn{6}{|l|}{ Западный макросклон } \\
\hline Сев. часть (Родников & 2359 & 2279 & 1951 & 1452 & 0 \\
\hline Цент & 2374 & 2281 & 1954 & 1430 & 0 \\
\hline Южн. часть (Анучино) & 2504 & 2827 & 2534 & 1899 & 1043 \\
\hline \multicolumn{6}{|l|}{ Южн. часть Сихотэ-Алинь } \\
\hline (Молча & 2614 & 2518 & 2177 & 1566 & 550 \\
\hline (Преображение) & 2596 & 2473 & 2014 & 1288 & 0 \\
\hline \multicolumn{6}{|l|}{ Вершины гор } \\
\hline $1570 \mathrm{M})$ & 1332 & 1217 & 914 & 0 & 0 \\
\hline $31 \mathrm{M})$ & 1765 & 1663 & 1279 & 641 & 0 \\
\hline Ливадийская, 1220) & 1765 & 1721 & 1315 & 582 & 0 \\
\hline
\end{tabular}




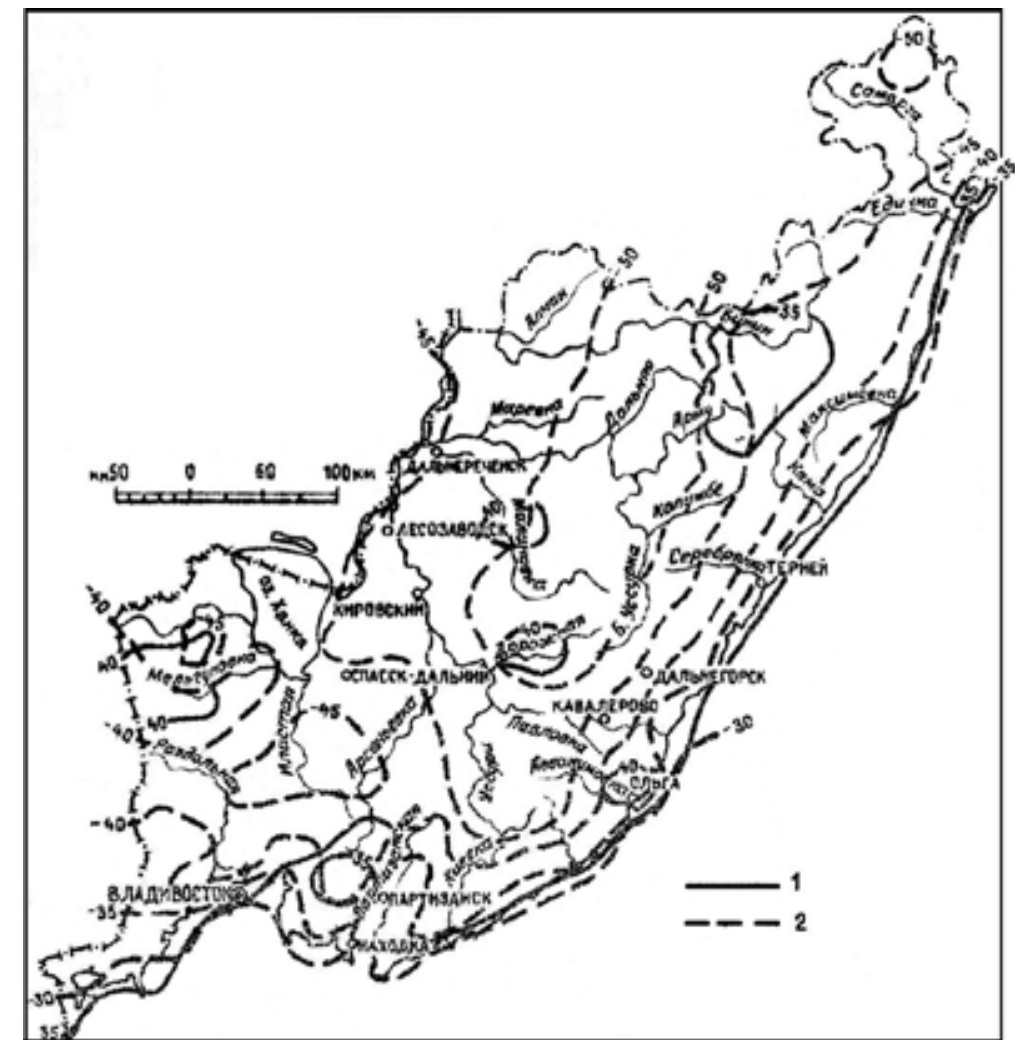

Puc. 3. Абсолютный максимум (1) и минимум (2 )температуры воздуха в летний период [192]

Наступление последних заморозков весной, первых заморозков осенью отличается большим разнообразием. Период, в течение которого прекращаются последние весенние заморозки, растягивается по территории края с юга на север на 2 мес (с 13 апреля по 14 июня включительно).

Наступление первых заморозков осенью происходит в обратном порядке, но только более интенсивно (в течение 1,5 мес. морозами охватывается вся территория края).

Средняя продолжительность безморозного периода колеблется от 96 дней в северной горной части до 155 в южной части побережья зал. Петра Великого. Отклонения могут достигать в сторону минимума 30 дней, максимума - 20 дней (т.е. безморозный минимум 60 дней, безморозный максимум - 215 дней). Продолжи- тельность безморозного периода в южной части края на 20-50 дней длиннее продолжительности периода с температурой выше $10^{\circ}$. В горной части Приморья, севернее $44^{\circ}$ с.ш., и в приводораздельных районах, южнее этой линии, продолжительность безморозного периода всего на 4-7 дней меньше продолжительности периода с температурой выше $10^{\circ}$. Это свидетельствует о том, что заморозки оканчиваются весной до перехода средних суточных температур через $10^{\circ}$ и начинаются осенью в тот период, когда средние суточные температуры ниже $10^{\circ}$.

Ветровой режим ландшафтов Приморского края определяется наличием двух противоположных потоков воздуха в зимний и летний периоды (рис. 4).

Зимой преобладают северные и северо-западные потоки, повторяемость которых в сумме составляет 70-94\%, а летом - юж-

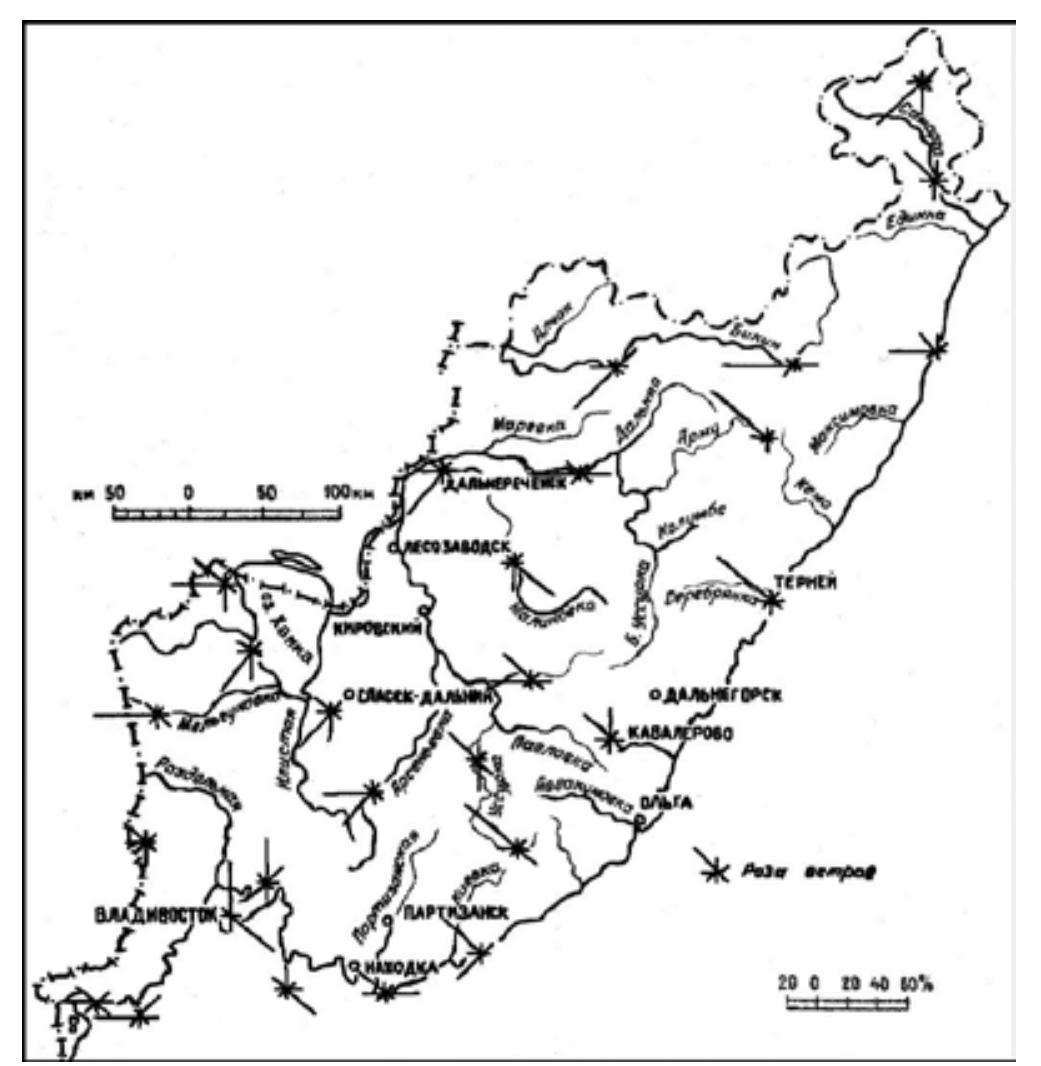

Puc. 4. Повторяемость направления ветра. Год. [186] 
ные и юго-восточные с повторяемостью 60-72\%. Однако в приземном слое направление потоков, как летних, так и зимних, значительно изменяется под воздействием горных вершин, гребней водоразделов, береговой полосы, речных долин и межгорных впадин [186]. В речных долинах, примыкающих к равнинам, преобладают ветры, соответствующие направлению долин на каждом их отрезке. На побережье отклонение направления ветра при выходе с моря на материк может достигать $90^{\circ}$. В значительных пределах изменяется направление ветров при обтекании горных цепей, массивов и отдельных вершин.

Средние годовые скорости ветра изменяются по территории края от 1 до 10 м/с. Изменение скорости ветра в таких пределах обусловливается рядом причин, из которых основными являются географическое положение и орография местности. В зимнее время скорости ветра составляют, в среднем, в континентальных районах 2-4 м/с, на восточном макросклоне и морском побережье 5-7 м/с, на вершинах гор - до 11 м/с. В теплое время года, с уменьшением барического градиента, скорости ветров повсеместно уменьшаются. Воздушные массы летнего муссона малой циркуляции редко переваливают через главный водораздел Сихотэ-Алиня. На западном макросклоне часто отмечаются небольшие скорости ветра и даже штили (табл. 5).

Сильные сухие ветры (суховеи) западного и северо-западного направлений ежегодно отмечаются с апреля по октябрь в континентальных районах края. Наибольшее их число наблюдается в апреле-мае в пределах всей Уссури-Ханкайской равнины и, особенно, в ее южной части. Весенние суховеи сопровождаются пыльными бурями. Продолжительность этих бурь достигает 10-15 ч в сутки, иногда с ежедневной повторяемостью в течение 1,5-2 нед.

Влажность. Большая часть ландшафтов территории Приморского края входит в зону влажного климата. Муссонная циркуляция вызывает резкую смену влажности воздуха в течение года. В суточном ходе наиболее высокая относительная влажность воздуха в 13 ч отмечается на побережье Японского моря в июле (85-90\%), в южной части края и на Уссури-Ханкайской равнине (до г. Лесозаводск) в июле-августе (65-80\%), на остальной (северной) части Уссури-Ханкайской равнины и низкогорного терригенного рода ландшафтов Сихотэ-Алиня в августе (63-70\%). Только в межгорных котловинах Сихотэ-Алиня и на высотах более 700 м над уровнем моря наиболее высокая относитель-

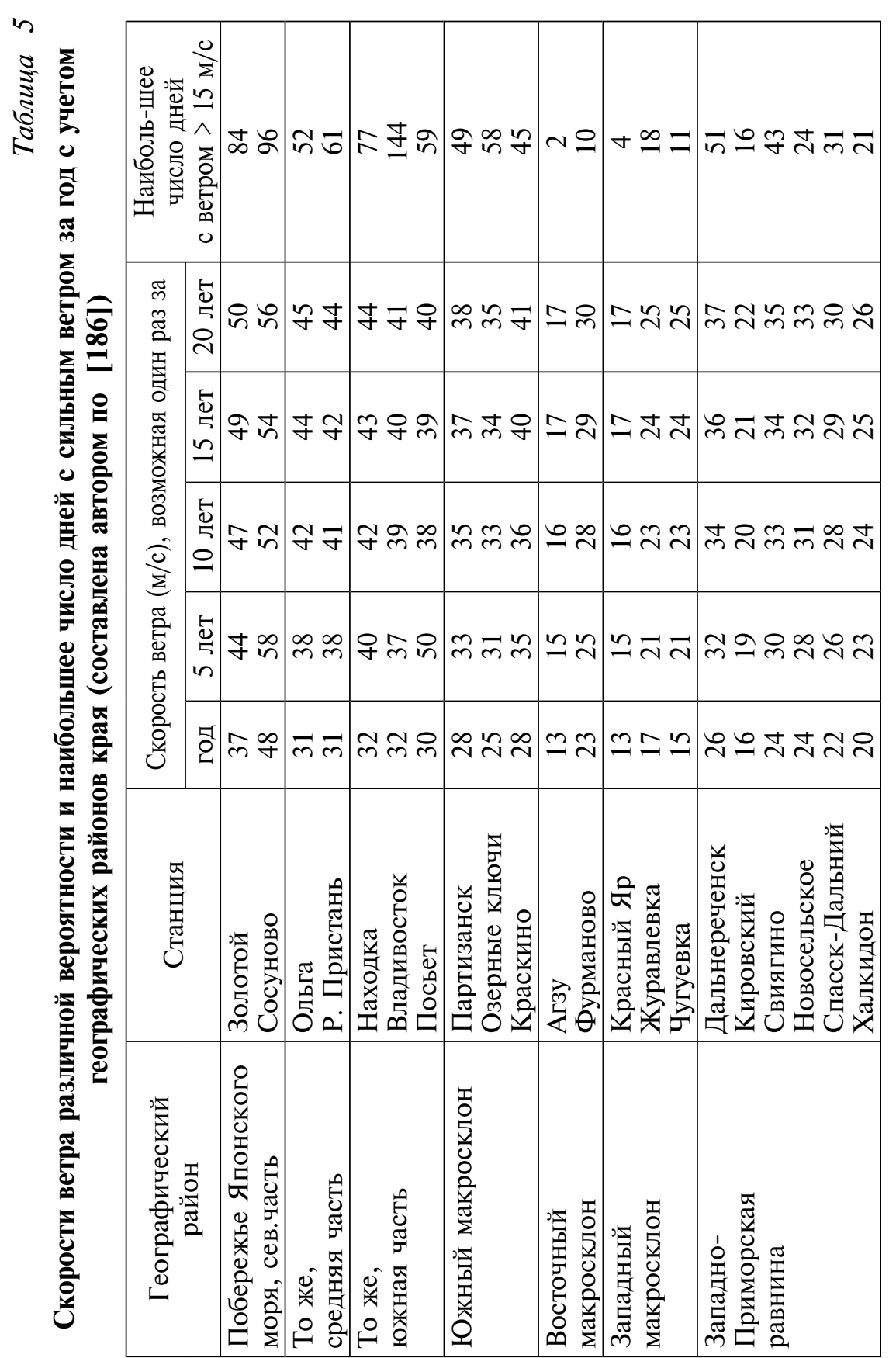


ная влажность воздуха в 13 ч наблюдается в декабре - январе (60-80\%)

Сильные сухие ветры (суховеи) западного и северо-западного направлений ежегодно отмечаются с апреля по октябрь в континентальных районах края. Наибольшее их число наблюдается в апреле-мае в пределах всей Уссури-Ханкайской равнины и, особенно, в ее южной части. Весенние суховеи сопровождаются пыльными бурями. Продолжительность этих бурь достигает $10-15$ ч в сутки, иногда с ежедневной повторяемостью в течение 1,5-2 нед.

Влажность. Большая часть ландшафтов территории Приморского края входит в зону влажного климата. Муссонная циркуляция вызывает резкую смену влажности воздуха в течение года. В суточном ходе наиболее высокая относительная влажность воздуха в 13 ч отмечается на побережье Японского моря в июле (85$90 \%$ ), в южной части края и на Уссури-Ханкайской равнине (до г. Лесозаводск) в июле-августе $(65-80 \%)$, на остальной (северной) части Уссури-Ханкайской равнины и низкогорного терригенного рода ландшафтов Сихотэ-Алиня в августе (63-70\%). Только в межгорных котловинах Сихотэ-Алиня и на высотах более 700 м над уровнем моря наиболее высокая относительная влажность воздуха в 13 ч наблюдается в декабре - январе (60-80\%).

Сочетание летом высокой температуры воздуха в дневные часы суток с высокой относительной влажностью во время наибольшего испарения усиливает впечатление зноя, что является одной их характерных особенностей климата края, влияющих на производительность труда при полевых работах. В условиях высокой влажности снижается не только производительность живого труда, но и ухудшаются условия стабильной работы механизмов, аппаратуры и приборов, уменьшаются сроки службы снаряжения и спецодежды. В то же время высокая влажность воздуха в теплый период года резко увеличивает конденсационную составляющую в общем круговороте поверхностных и подземных вод горнолесного смешанно-широколиственного подкласса ландшафтов, обеспечивая водность даже мелких ручьев в течение всего года.

Переходные сезоны года - весна и осень - характеризуются низкой относительной влажностью. Один из годовых минимумов влажности в теплый период приходится обычно на апрель. Следствие этого - отчетливо выраженный пожароопасный период в лесах. Осенью, обычно в октябре, образуется второй годовой минимум влажности и, соответственно, второй пожароопасный период. В отдельные годы с ранней весной, поздней осенью и с летними засухами пожароопасный период в лесах Приморья может длиться почти 9 мес.

Атмосферные осадки. Отличительной чертой климата ландшафтов Приморского края является обилие летних осадков, во много раз превышающих количество зимних. Здесь наблюдается не простое преобладание летних осадков, как на других материках, а еще и в сочетании с большой относительной влажностью и облачностью [29]. Картина распределения осадков во времени и пространстве зависит от географического положения и рельефа отдельных районов. Зимой со стороны Центральной Азии поступает сухой и холодный континентальный воздух. Слой его, имеющий мощность около 4 км, легко преодолевает средневысотный Сихотэ-Алинь, Восточно-Маньчжурское нагорье и отодвигает далеко к юго-востоку и востоку границу континентальности [173]. Поэтому зимой повсеместно в крае наблюдается холодная, малооблачная, сухая погода. Значительно существеннее выражена барьерная роль Сихотэ-Алиня и Восточно-Маньчжурского нагорья по отношению к летним воздушным массам. Вертикальная мощность их, особенно в первую половину лета, соизмерима с отметками гор Приморья, что способствует интенсивной конденсации атмосферной влаги на макросклоне, обращенном к морю, или вблизи линии главного водораздела.

Главный водораздел горного хр. Сихотэ-Алинь в целом оказывает существенное влияние на развитие атмосферных процессов как в районе самого водораздела, так и на прилегающих к нему участках. Пространственная ориентировка долин, отрогов и экспозиция склонов к направлению влагонесущих воздушных потоков на каждом конкретном участке горного класса ландшафтов Сихотэ-Алиня является решающим фактором распределения осадков. Долины, ориентированные с востока на запад и с северо-востока на юго-запад, суживающиеся, соответственно, к востоку и северо-востоку, характеризуются повышенными количествами осадков (Ново-Полтавка - 724 мм, Вострецово 789 мм, Глубинное - 829 мм). В закрытых долинах и котловинах центральной части горной страны Сихотэ-Алинь количество осадков существенно уменьшается по сравнению с горной частью. К примеру, на ГМС Охотничье, расположенной в пределах замкнутого участка долины р. Бикин, годовое количество осадков - 657 мм, а на ГМС Высота 1647, расположенной в 50 км юго-восточнее на вершине главного водораздела Сихотэ-Алиня 
и более открытой влагонесущим потокам, количество осадков достигает 900 мм в год.

Количество осадков в крае варьирует в основном от 500 до 900 мм. Наибольшая годовая сумма осадков, 800-900 мм, наблюдается на западном побережье зал. Петра Великого. Годовая сумма 750-900 мм отмечается на западных склонах северной части Сихотэ-Алиня; 700-850 мм - на побережье Японского моря и прилегающих восточных склонах Сихотэ-Алиня; 600-750 мм в северной и 500-600 мм - в южной частях Уссури-Ханкайской равнины (рис. 5), [185].

Наблюдающаяся пятнистость в распределении осадков по территории края есть результат сложного взаимодействия неровностей рельефа, абсолютной высоты местности и ее лесистости с циркулирующими над ней влагонесущими потоками. Годовая

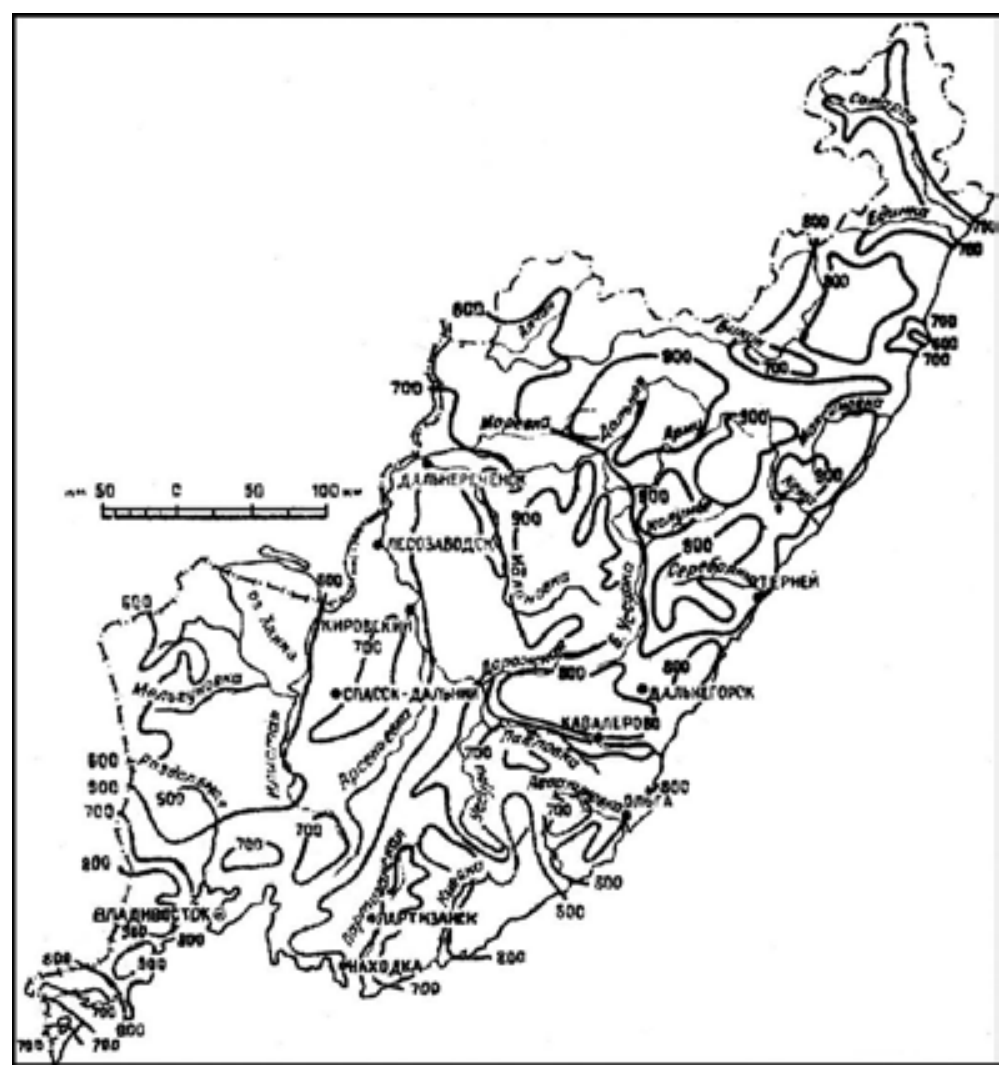

Рис. 5. Карта количества осадков [185] сумма осадков значительно возрастает при поднятии в горы. Так, в бассейне р. Большая Уссурка вертикальный градиент составляет от 74 до 170 мм, а в бассейне р. Комаровка даже до 180 мм на 100 м в год. Годовое количество осадков в южном Сихотэ-Алине на высотах 1000-1 100 м может достигать 1300-1400 мм.

Годовой ход осадков в целом по ландшафтам края характеризуется минимумом в январе - феврале (всего 1-3 мм) и максимумом в августе. Исключение составляют центральный и северный горные районы (Журавлевка, Глубинное, Охотничье, Высота 1647), где максимум осадков может смещаться на июль, а на севере побережья Японского моря - на сентябрь. Месячные суммы осадков из года в год в крае колеблются в значительных пределах. Например, в июле, при средней сумме 60-190 мм, в отдельные годы наблюдались суммы от 7-12 мм (1923, 1931 гг.) до 350446 мм (1942, 1950 гг.), что близко в первом случае к количеству осадков, выпадающих в пустыне, а во втором - в субтропиках. Непрерывная продолжительность осадков в отдельные годы меняется так же значительно: осенью и зимой от 3 до 130 ч, летом от 15 до 300 ч. Продолжительность отдельных дождей бывает от нескольких минут до многих суток.

Общая продолжительность осадков за год по всей территории составляет от 700 до 1000 ч. В годовом ходе наибольшая суммарная продолжительность осадков, как и их продолжительность в день с осадками, наблюдается в июле - августе, а наименьшая - в январе - феврале. В среднем за год на юге побережья и на Уссури-Ханкайской равнине, включая западные предгорья Сихотэ-Алиня, приходится 80-90\% - на жидкие и 3-4\% - на смешанные (мокрый снег, снег с дождем и пр.). На восточном побережье количество твердых осадков возрастает до 12-14\% и в горах доходит до $20 \%$. Число дней с осадками более 0,1 мм колеблется на побережье и на Уссури-Ханкайской равнине от 95 до 120 [187, 166], в центральных и горных районах от 125 до 160, из них, на благоприятный для проведения экспедиционных работ период апрель - октябрь падает от 62 до $81 \%$ общего годового количества дней с осадками. В абсолютных цифрах это означает от 67 до 108 дней с осадками из 214 календарных дней, или от 31 до $50 \%$ всего времени, возможного для проведения экспедиционных ландшафтных работ (материалы ПУГКС, 1981 г., рис. 6). К этому нужно добавить дни с малыми осадками (т.е. менее 0,1 мм в сутки). Их за период IV-X месяцы бывает от 5 (Маргаритово) до 18 (Терней) (табл. 6). 


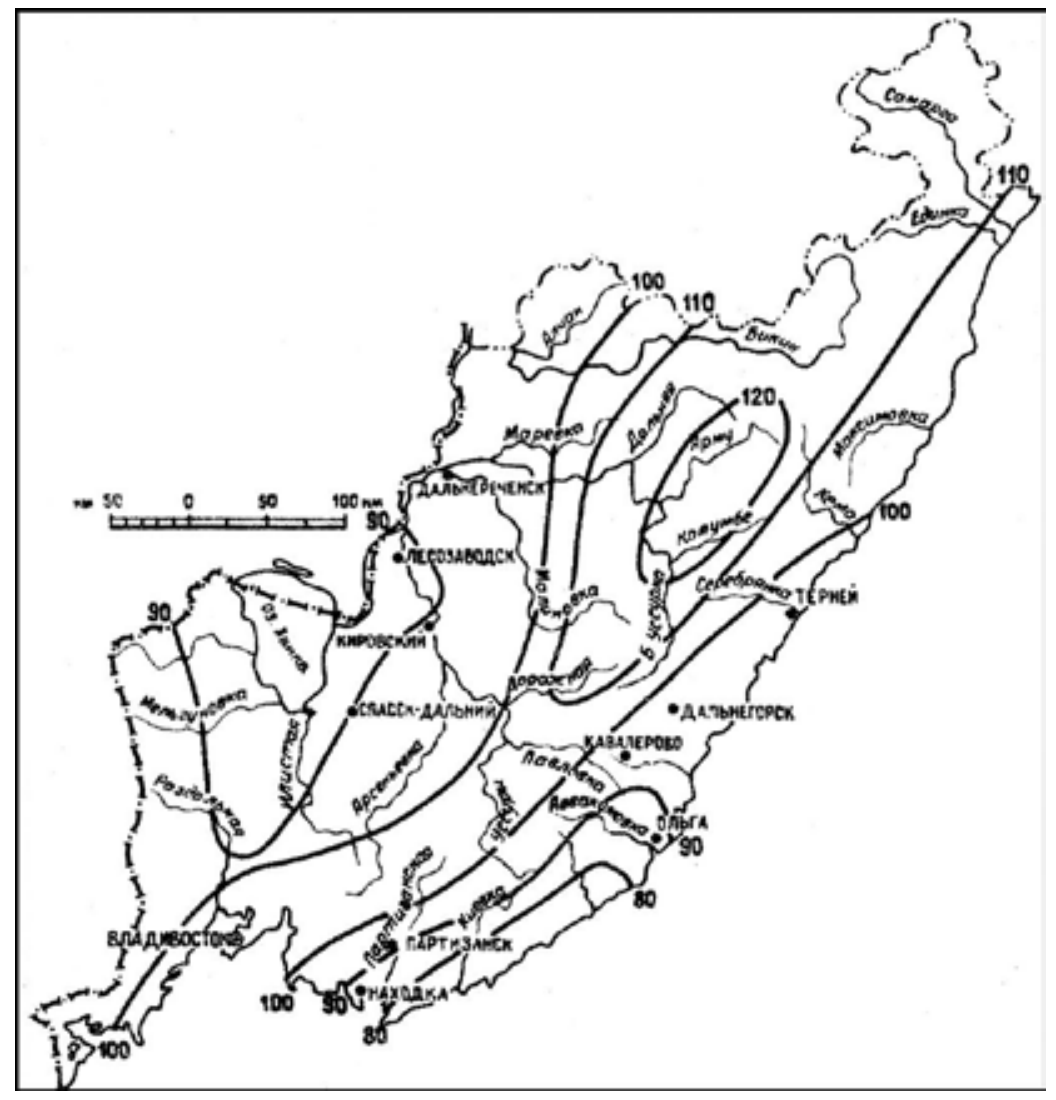

Рис. 6. Карта среднего числа дней с осадками любой интенсивности за период с 1 апреля по 31 октября (материалы ПУГКС, 1981 г.)

Снежный покров. Даты выпадения первого снега очень близки к датам перехода температуры воздуха через 0о. На вершинах Сихотэ-Алиня это обычно первая и вторая декады октября, в континентальных северных районах - третья декада октября, южных - первая-вторая декады ноября, на побережье - втораятретья декады ноября (рис. 7) [187]. Первый снег чаще всего стаивает при оттепелях, и только через 3-5 недель после выпадения первого снега образуется устойчивый снежный покров. Быстрое осеннее понижение температуры в условиях отсутствия снежного покрова приводит к глубокому сезонному промерзанию грунтов. Глубина проникновения отрицательных температур на горных склонах часто превышает мощность рыхлых накоплений, что
Количество осадков по гидрологическим станщиям Приморского края (составлена автором по [166, 187])

\begin{tabular}{|c|c|c|c|c|c|c|c|}
\hline \multirow[t]{2}{*}{$\begin{array}{c}\text { № } \\
\Pi / \Pi\end{array}$} & \multirow{2}{*}{$\begin{array}{c}\text { Гидрометеоро- } \\
\text { логическая } \\
\text { станция }\end{array}$} & \multicolumn{2}{|c|}{$\begin{array}{c}\text { Осадки } \\
\text { более } \\
0,1 \mathrm{мм} \\
\end{array}$} & \multicolumn{2}{|c|}{$\begin{array}{c}\text { Осадки } \\
\text { менее } \\
0,1 \text { мм } \\
\end{array}$} & \multicolumn{2}{|c|}{ Всего } \\
\hline & & дни & $\%$ & дни & $\%$ & ДНИ & $\%$ \\
\hline 1 & Золотой & 88 & 41 & 13 & 6 & 101 & 47 \\
\hline 2 & Охотничий & 100 & 47 & 13 & 6 & 113 & 53 \\
\hline 3 & Вострецово & 99 & 45 & 13 & 6 & 112 & 52 \\
\hline 4 & Дальнереченск & 84 & 39 & 9 & 4 & 93 & 43 \\
\hline 5 & Мельничное & 108 & 50 & 12 & 6 & 120 & 66 \\
\hline 6 & Маликово & 93 & 43 & 13 & 6 & 105 & 49 \\
\hline 7 & Терней & 75 & 35 & 18 & 8 & 93 & 43 \\
\hline 8 & Журавлевка & 95 & 44 & 11 & 5 & 106 & 49 \\
\hline 9 & Спасск-Дальний & 83 & 39 & 9 & 4 & 92 & 43 \\
\hline 10 & Яковлевка & 83 & 39 & 11 & 5 & 94 & 44 \\
\hline 11 & Пограничный & 76 & 35 & 17 & 8 & 93 & 43 \\
\hline 12 & Богополь & 81 & 38 & 13 & 6 & 94 & 44 \\
\hline 13 & Анучино & 81 & 38 & 13 & 6 & 94 & 44 \\
\hline 14 & Тимирязевский & 76 & 35 & 13 & 6 & 89 & 41 \\
\hline 15 & Маргаритово & 75 & 35 & 5 & 2 & 80 & 37 \\
\hline 16 & Владивосток & 88 & 41 & 13 & 6 & 101 & 47 \\
\hline 17 & Преображение & 57 & 31 & 9 & 4 & 76 & 35 \\
\hline 18 & Краскино & 82 & 39 & 13 & 6 & 95 & 45 \\
\hline 19 & Поворотный & 73 & 34 & 9 & 4 & 82 & 38 \\
\hline
\end{tabular}

способствует интенсивному физическому выветриванию скальных пород и активному перемещению грубообломочного материала из глубины на поверхность (морозное выпучивание).

Наибольшая высота снежного покрова в лесу на западных отрогах Сихотэ-Алиня 40-60 см (в распадках до $100 \mathrm{~cm}$ ), на восточных - 20-35 см, на открытых полях в северной части края 30-50 см, на остальной территории 10-30 см. К концу зимы на открытых участках высота снежного покрова бывает на 10-20 см меньше, чем на защищенных участках при равной первоначальной величине. Со второй-третьей декады марта высота снежного покрова уменьшается, временами выпадают осадки в жидком виде, появляются частые дневные оттепели, снег подтаивает, уплотняется. Разрушение и сход устойчивого снежного покрова происходят в более сжатые сроки, чем его образование. К концу 


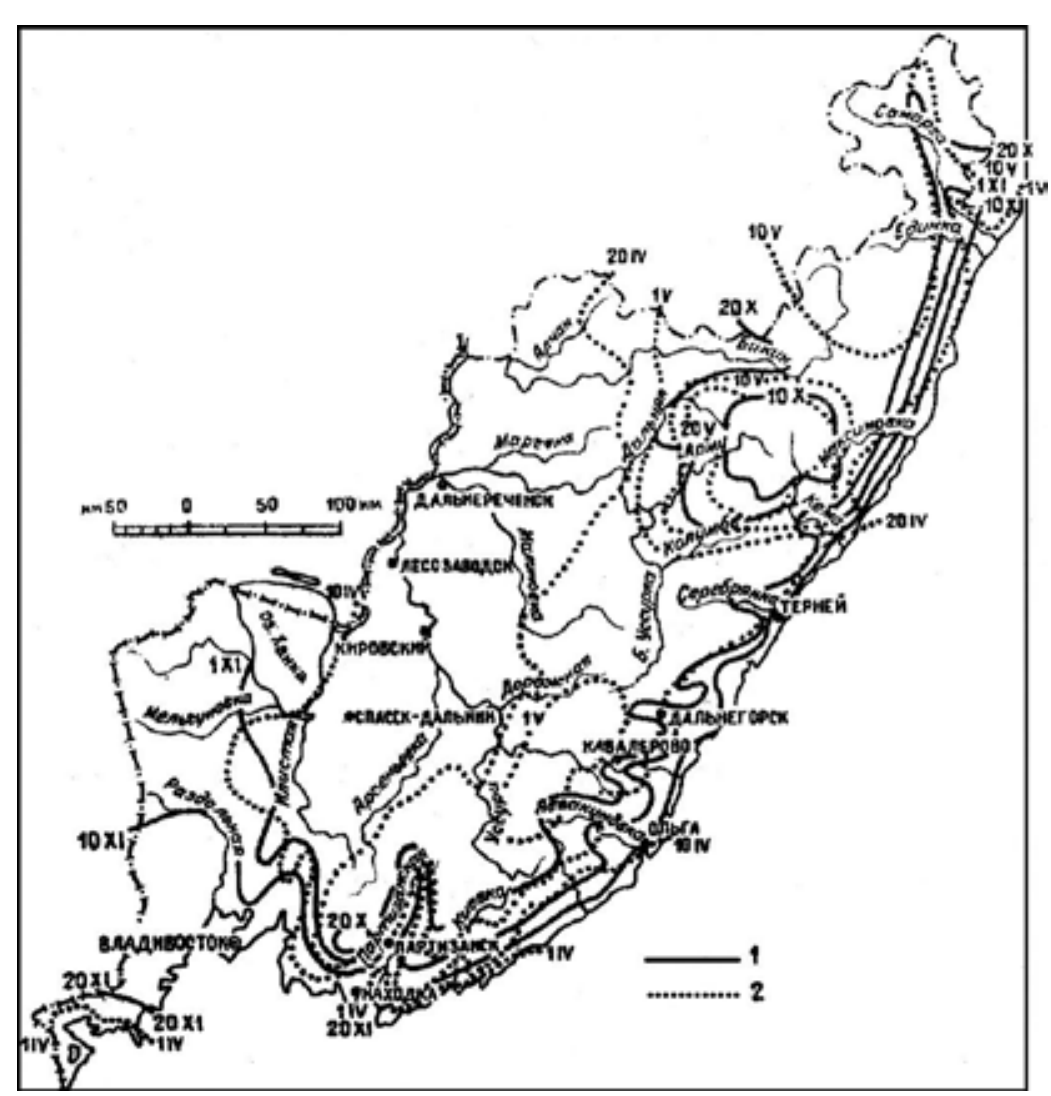

Puc. 7. Средние даты появления (1) и схода (2) снежного покрова [187]

апреля вся зона равнинного типа и мелкосопочного полисубстратного рода ландшафтов территории края освобождается от снега В среднегорных полисубстратных родах ландшафтов снег сохраняется до конца первой декады мая, а на высотах более 1500 м даже до середины третьей декады мая. Отдельные снежники, формирующиеся в местах образования зимних снеговых надувов в подгольцовом поясе самых высоких гор, сохраняются в течение всего июня. Число дней со снежным покровом в среднем за зиму составляет в зоне низкогорного терригенного рода ландшафтов и на вершинах Сихотэ-Алиня 140-210, на Уссури-Ханкайской равнине 85-140, на побережье Японского моря от 45 на юге до 140 на севере.

\section{Контрольные вопросы}

1. В какой климатической области располагается территория Приморского края?

2. Каким характером циркуляции определяется климатические особенности Приморья?

3. Под воздействием каких воздушных масс находится Приморье поздней осенью и зимой?

4. Сколько времени в климате края существует континентальный режим?

5. Что понижает континентальность климата в Приморье?

6. Какой климат в целом в Приморье?

7. Определяет ли климат географическое положение Приморья?

8. Как влияет на климат главный водораздельный хребет Сихотэ-Алиня?

9. Охарактеризуйте солнечную радиацию как климатообразующий фактор.

10. Охарактеризуйте температурный режим ландшафтов Приморья.

11. Охарактеризуйте ветровой режим ландшафтов Приморья.

12. Охарактеризуйте режим влажности ландшафтов Приморья.

13. Охарактеризуйте общий режим атмосферных осадков в Приморье.

14. Охарактеризуйте особенности снежного покрова в Приморье.

15. Охарактеризуйте дифференциацию снежного покрова по ландшафтам Приморья. 


\section{Лекщия 6}

\section{РЕГИОНАЛЬНАЯ ПРИРОДНО-КОМПОНЕНТНАЯ СПЕЦИФИКА ПРИМОРЬЯ (воДЫ)}

Распределение стока во времени и пространстве. Водотоки зоны равнинного (включаются долинно-речные горного) класса ландшафтов Приморского края, отражая сезонную и многолетнюю динамику их водного режима, отличаются большой неустойчивостью. Возникновение паводков возможно в любое время теплой половины года, а распределение стока во времени и по территории весьма не равномерно. В зоне ландшафтов западного макросклона Сихотэ-Алиня средние годовые модули стока составляют 5-10 л/сек км ${ }^{2}$ (70-50, 70-22, 75-38, 84-24 и др.- здесь и далее номера местностей на карте), восточного - 10-20 л/сек $\mathrm{KM}^{2}(62-29,75-45,76-48,87-35$ и др.), на юге края - 10-15 л/сек км ${ }^{2}(70-5,70-6,84-5,84-8$ и др.), а на Уссури-Ханкайской равнине не превышают 2-5 л/сек км² (83a-15, 88-4 и др.). Исследованиями ДВНИИ установлено, что вертикальный градиент модуля годового стока в бассейне р. Уссури составляет $1-3$, а в бассейнах рек, впадающих в Японское море - 0,6-0,8 л/сек км$^{2}$ на каждые 100 м подъема. Крайней неравномерностью отличается внутригодовое распределение стока. Основная масса воды (90-95\% годового объема) стекает в теплую часть года (апрельоктябрь), и лишь 5-10\% - в зимней период.

Для водотоков, стекающих с восточных склонов Сихотэ-Алиня, характерны значительные подъемы воды весной и сравнительно небольшие паводки, хотя суммы и интенсивность выпадения осадков здесь высокие. Сказывается огромная водорегулирующая роль лесной растительности, уменьшающей скорость добегания осадков. Осадки проделывают длинный путь через лесную подстилку, почву, рыхлые надпочвенные накопления в верхнюю трещиноватую зону скальных пород и уже только оттуда поступают в водотоки. Средние модули стока на восточных склонах Сихотэ-Алиня с марта по май составляют 10-15 л/сек км², с июня по октябрь - 15-21 л/сек км². зимой сток отличается устойчивостью и высокими значениями - 1,5-2 л/сек км ${ }^{2}$ (64-9, 75-41, 76-10, 85-9, 85-11 и др. местности).

На водотоках южной части края отчетливо выделяются фазы весенне-летнего и летне-осеннего стока с максимумами в мае и августе-сентябре. Исключение составляют реки, стекающие с Восточно-Маньчжурских гор (73-1, 86-6, 86-9 и др.местности), на которых весенний паводок отсутствует. Модули стока за весенний и летне-осенний периоды на юге края примерно одинаковы $(11-12$ л/сек км²). Зимой они составляют 1,2-1,9 л/сек км².

Водотоки западного макросклона на Сихотэ-Алине имеют хорошо выраженные весенне-летние и летне-осенние паводки с резкими подъемами, спадами и высокими максимальными расходами. Модули стока за весну составляют 10-17 л/сек км², за лето-осень $-9-24$ л/сек км². Зимой сток воды значительно меньше, чем на восточном и южном макросклонах Сихотэ-Алиня $(0,6-0,7$ л/сек км²). Лишь на крутых реках он составляет более 1 л/сек кM ${ }^{2}$.

В восточной части Уссури-Ханкайской равнины водность рек весной значительно выше, чем в летнее-осенний период. Модули стока соответственно равны 14-22 и 3-6 л/сек км². В западной части равнины модули весеннего стока рек составляют 3-4, летне-осеннего - 5-6 л/сек км². Зимой сток на равнине самый низкий в крае $-0,05-0,3$ л/сек км².

Гидрограммы стока рек Приморья имеют многопиковую форму и крайне изменчивы. Максимальные расходы воды в период паводков в сотни раз превышают минимальные летние, что является характерной чертой неустойчивости водного режима рек. Минимальный зимний сток примерно в 10 раз меньше минимального летнего. Многие реки периодически перемерзают и пересыхают.

Резкое изменение расходов воды в летнее время приводит к крайне неравномерной транспортировке влекомых наносов водотоками. Эти наносы приобретают все черты, свойственные образованиям катастрофических потоков (несортированность или плохая сортировка, хаотическое нагромождение крупнообломочного материала, грядо- или валообразное накопление его и т.п.)

Уменьшение зимних расходов в водотоках Приморья в сочетании с низкими температурами приводит к промораживанию с одновременным осушиванием всей (или большей части) 
толщи ранее обводненных отложений. В этих условиях, вокруг зерен песчаных фракций возникают глинистые пленки нерастворимые в воде и даже в кислотах. Появление пленок связано с процессами попеременного промерзания и оттаивания рыхлых накоплений. Наибольшим содержанием таких минералов с пленками характеризуются элювиальные, склоновые и аллювиальные осадки гольцовой зоны (1-гольцовый полисубстратный род ландшафтов).

Паводочный режим рек. Паводочный режим рек равнинных и долинно-речных ландшафтов Приморья своеобразен. В соответствии с климатическими условиями наблюдаются два паводочных периода. Первый период - весенне-летний (с апреля по июнь), когда на невысокое весеннее половодье накладываются дождевые паводки. Второй период летне-осенний (с июля по октябрь) сопровождается двумя-тремя, а в отдельные годы и шестью паводками, между которыми наступает кратковременная межень. Изменение уровней в многолетнем разрезе зависит от колебаний водности рек, интенсивности ледовых явлений и русловых деформаций. При сравнении рек зон равнинных и долинно-речных ландшафтов одинаковой водности (например, p. Уссури у с. Бреевки и р. Илистой у с. Халкидон) установлено, что амплитуда колебаний уровней рек долинных горных ландшафтов меньше, чем у равнинных. Наиболее значительные колебания уровней (7-9 м) отмечены на р. Уссури у г. Лесозаводска и с.Тартышевка и на р. Раздольная у г. Уссурийска и с. Тереховка. Следует подчеркнуть, что высшие годовые уровни отличаются большой изменчивостью. Амплитуда их колебаний на больших реках составляет 2-6 м, а на средних $-1-4$ м (для сравнения отметим, что амплитуда изменений низших летних уровней от среднего расхода воды для всех рек не превышает 0,1-0,8 м). Во время прохождения паводков продолжительность подъема уровня воды 2-8 дней (в отдельные года до 10-20 дней). Спад уровня более растянут - до 15-30 дней. Интенсивность подъема колеблется от 0,3 до 5 м/сутки [214].

Весенние подъемы уровней на непромерзающих реках, если они происходят только за счет таяния снегов, не отличаются значительными величинами (1-3 м). Если же в этот период выпадают дожди, то уровни могут подниматься вдвое выше и скорость нарастания паводка резко возрастает. Особенно большие и катастрофически быстрые подъемы уровней бывают при заторах льда. Прохождение волн льдоводокаменных (селеподобных) паводков на реках горной и предгорной частей края явление настолько частое, что следы его можно обнаружить на любой реке в виде забоев и обдиров на стволах прибрежных деревьев. Изучая срезы (спилы) таких стволов можно с достаточной достоверностью подсчитать частоту прохождения катастрофических паводков, а картирование береговых глубинных гряд, валов, эрозионных уступов, заломов, завалов, островов, кос и других элементов русловой и прирусловой ситуации (особенно по аэроснимкам разных лет) позволяет составить картину динамики русловых деформаций и переформирования пойменных и долинных урочищ и фаций. Это чрезвычайно важно для оценки условий транспортировки и аккумуляции обломочного материала, динамики современных русел.

В летний период на реках края можно выделить в общих чертах три типа колебания уровней рек.

Первый тип свойственен рекам Уссури-Ханкайской равнины (83a-7, 83a-9 и др. местности). Поймы этих рек широкие изрезаны меандрами и старицами, изобилуют болотами и озерами. Продолжительные дожди формируют на этих реках паводки, имеющие на графике вид хорошо выраженных волн с медленным подъемом и спадом уровней. Для этого района характерны частые и длительные наводнения.

Второй тип колебания уровней присущ рекам зон низкогорных терригенных и мелкосопочных полисубстратных ландшафтов западного и восточного макросклонов Сихотэ-Алиня (62-31, 65-18, $71-4,75-39,78-18,87-4$ и др. местности). Реки этой зоны характеризуются менее плавными, частыми, но непродолжительными наводнениями. Паводочный режим выражен отчетливо.

Третий тип характерен для рек среднегорных полисубстратных ландшафтов (62-40, 76-7, 76-17, 76-42 и др. местности). На графиках колебания уровней хорошо выражены островерхие наводочные волны. Характерной чертой режима этих рек являются интенсивные паводки в теплую часть года, обусловленные обильными осадками.

По продолжительности затопления пойм территорию Приморья можно разделить на четыре района [214]. Наиболее продолжительные разливы в году (от 50 до 130 суток) наблюдаются в долине р. Уссури и в нижнем течении рек Чистая, Мельгуновка, Б. Уссурка. Менее продолжительные наводнения (до 50 суток) отмечаются на участках рек зоны низкогорного терригенного рода ландшафтов (нижнее и среднее течение р. Арсеньевки, 
Малиновки, Бикина и р. Уссури от с. Извилинки до впадения в нее р. Арсеньевки, 70-35, 83a-25, 85-21 и др. местности). Непродолжительные наводнения характерны для горных рек. Поймы рек, стекающих с западных отрогов хр. Сихотэ-Алинь, в течение лета залиты водой 10-15 суток, с восточных склонов менее 10 суток.

Верховодка. Верховодка, т.е. временное скопление воды в зоне аэрации выше постоянного первого от поверхности водоносного горизонта, довольно широко распространена в ландшафтах Приморского края. Наиболее известна верховодка, связанная с сезонной, а в горных ландшафтах и с многолетней мерзлотой. Мерзлые грунты, достигая к концу зимы мощности 1,5-2 м, весной начинают медленно протаивать с поверхности. Для южных районов этот процесс длится с начала марта до середины мая, а в северных районах со средины марта до июня-июля месяцев и даже позже (в зависимости от погоды). Таким образом, мерзлота под поверхностью оттаявшего слоя почвы сохраняется длительное время (от 2,5 месяцев и более). При этом верхний оттаявший слой грунта насыщается талыми водами, которые из-за мерзлоты не могут проникнуть до постоянного горизонта грунтовых вод. Надмерзлотная верховодка развивается на любых поверхностях с малыми и средними уклонами, сложенных супесчаными и суглинистыми почво-грунтами. Другой причиной появления верховодки является различная водопроницаемость склоновых отложений по разрезу. Для делювия, являющегося наиболее распространенным генетическим типом существенно глинистых склоновых накоплений, характерна наименьшая водопроницаемость в средней части разреза (горизонт вымывания). При интенсивном насыщении грунтов влагой с поверхности или за счет разгрузки трещинных подземных вод на участках пологих и выположенных склонов $\left(20^{0}\right.$ и менее) образуется верховодка. Возникновению ее способствуют такие периодические изменения кислотности и щелочности почво-грунтов, проистекающие под воздействием природно-климатических факторов. Сходного типа верховодка проявляется в пределах развития глинистых кор выветривания, развитых в платобазальтовом роде ландшафтов и плоских поверхностях выветривания.

Особым типом верховодки являются воды торфяников, развитые на берегах оз. Ханка (89 и др. виды ландшафтов), низменных участках морского побережья (59a-1, 60a-1 и др. местности), в долинах равнинных рек и в ландшафтах платобазальтового рода. В течение лета и осени слой торфа и оторфованных глин, мощность которого достигает иногда 3 м (чаще $0,5-2$ м), перенасыщается водой. В любом случае избыточному увлажнению торфяников способствует то обстоятельство, что они подстилаются глинами. В течение сухого холодного периода (осень-зима) эта верховодка исчезает, расходуясь в основном на питание рек. Значительную роль в дренаже торфяников в последнее время стали играть осушительные каналы.

Основные особенности гидрогеологического режима подземных вод. По условиям формирования режима подземных вод вся территория ландшафтов Приморского края относится к провинции с устойчивым сезонным промерзанием зоны аэрации (фонды «Приморгеология»: Столяр и др. 1975 г.), по условиям же увлажненности она может быть разделена на зоны избыточного, достаточного и умеренного питания грунтовых вод.

Зона избыточного питания грунтовых вод охватывает побережье Японского моря, южные, центральные, а на севере и западные районы горных ландшафтов Сихотэ-Алиня (массивносреднегорный и расчлененносреднегорный полисубстратные, низкогорный терригенный и др. роды ландшафтов), т.е. примерно $70 \%$ всей территории края. Для этой зоны характерны самые большие суммы годовых осадков $(P=600+1000$ мм $)$ и самое малое испарение $\left(E=300+500\right.$ мм), т.е. коэффициент увлажнения $K_{y}=\frac{P}{E}$ более 1,5 . Одной из важных особенностей зоны является большая глубина сезонного промерзания грунтов. На значительной части площади она превышает мощность рыхлых склоновых накоплений (1,5-2 м). В весеннее время, когда происходит быстрое нарастание дневных температур, талые воды просачиваются в переохлажденные склоновые накопления и там замерзают. Такие льдистые грунты под пологом лесной растительности оттаивают очень медленно, а на склонах северной экспозиции вообще возможно образование сезонных мерзлотных перелетков или даже глубоко залегающей многолетней мерзлоты. Так в конце мая 1958 года на правом борту долины р. Мельники (близ пос. Углекаменск Партизанского района) высокольдистые рыхлые склоновые накопления были вскрыты скважиной на интервале 2,6-25,0 м, при общей мощности склоновых накоплений 32,85 м (фонды «Приморгеология»: Кузнецов, 1971 г.).

В рассматриваемой зоне развиты, в основном, трещинные воды, формирующиеся в верхнем трещиноватом слое скальных 
пород. Небольшие запасы приурочены к аллювию и пролювию горных рек эрозионно-аккумулятивного равнинного и долинноречного горного рода ландшафтов. Малая глубина проникновения эффективной экзогенной трещиноватости в скальные породы ограничивает запасы трещинных вод этой территории, а густая сеть долин и распадков способствует их быстрому и довольно интенсивному сбросу (дренированию) в поверхностные водотоки. Здесь наблюдается наиболее тесная и отчетливая связь режима грунтовых вод с климатом и осадками.

Зона достаточного питания грунтовых вод $\left(\mathrm{K}_{\mathrm{y}}=1,1-1,5\right)$ охватывает низменные части долин рек Уссури, Сунгач, Илистая, Раздольная (эрозионно-аккумулятивный равнинный род ландшафтов) и западные отроги Сихотэ-Алиня (низкогорный терригенный род ландшафтов), в примыкающих к данным частям долин рек районах. На севере и северо-западе эта зона граничит с зоной умеренного питания, на востоке, юго-востоке и юге с зоной избыточного увлажнения. Годовые суммы осадков для этой зоны 600-700 мм (в особо влажные годы 800-1000 мм, в засушливые $-400-500$ мм). Большая часть осадков выпадает в теплое время. Испарение в среднем составляет 400-500 мм. Глубина промерзания грунтов 1,5-2 м. Снежный покров в этой зоне более устойчив, чем в зоне обильного питания.

В пределах описываемой зоны развиты трещинные воды дислоцированных метаморфических пород протерозойского и нижнепалеозойского комплексов, интрузивных и эффузивных пород. Кроме грунтовых вод верхней трещиноватой зоны скальных пород и грунтовых вод рыхлых накоплений четвертичного возраста, здесь развиты напорные пластовые воды, приуроченные к палеоген-неогеновым отложениям межгорных впадин. Тип питания атмосферный, инфильтрационный. Область питания и область распространения для трещинных вод территориально совпадает, для грунтовых и пластовых - область питания значительно больше области распространения. Для трещинных вод скальных пород и грунтовых вод четвертичных отложений горной части описываемой зоны характерны тесная связь режима с режимом влажности и атмосферных осадков.

Зона умеренного питания грунтовых вод $\left(\mathrm{K}_{\mathrm{y}} \leq \mathbf{1 , 0 )}\right.$ охватывает территорию низкогорного терригенного и вулканогенно-терригенного рода ландшафтов северной части Восточно-Маньчжурских гор горного класса ландшафтов и Приханкайскую низменность эрозионно-аккумулятивного равнинного рода ландшафтов. В пре- делах зоны развиты преимущественно грунтовые воды отложений четвертичного и неогенового возрастов, если последние выходят на дневную поверхность, и напорные подземные воды, если указанные выше отложения сверху перекрыты полигенетическими глинами. Имеют распространение и трещинные безнапорные воды на участках выходов пород фундамента на поверхность. Тип питания грунтовых вод атмосферный, инфильтрационный, а также путем боковых притоков и перетекания с нижележащих напорных грунтов. Для уровней грунтовых вод аллювиальных отложений характерна тесная связь с уровненным режимом реки и такими климатическими элементами, как осадки, влажность, солнечная радиация, солнечное сияние, температура. Немаловажное значение для уровня грунтовых вод Приханкайской низменности имеет поведение уровня оз. Ханка.

Зона умеренного увлажнения по термическим ресурсам относится к умеренно жаркой зоне России и в тоже время является самой жаркой частью Приморского края. В дождливые годы годовая сумма осадков достигает 700 мм и даже более, в засушливые уменьшается до 300 мм. Потери осадков на испарение 75-50\% от годовой суммы. Зимой и весной очень низкая относительная влажность. Весной наблюдается иссушение почвы и ветровая эрозия. Глубина промерзания грунтов на открытых пространствах может достигать 2-2,5 м.

Внутри гидрогеологических зон по степени эрозионной расчлененности ландшафтов, а следовательно по степени дренированности территории выделяются три гидрогеологические области:

- слабодренированная до 0,5 км на км²;

- среднедренированная 0,6-0,9 км на км²;

- сильнодренированная более 0,9 км на км².

Гидрогеологическая область со слабой дренированностью грунтовых вод характеризуется глубиной расчленения эрозионной сетью 30-170 м (преобладает 70-80 м) и суммарной расчлененностью ландшафта до 0,5 км на $1 \mathrm{~km}^{2}$ площади. Она охватывает территорию с абсолютными отметками менее 200 м и в общих чертах совпадает с ландшафтами Уссури-Ханкайской равнины (эрозионно-аккумулятивного равнинного рода) и приморскими равнинами южной части побережья края (приморского равнинного рода ландшафтов). Ввиду широкого распространения в пределах области глинистых и суглинистых грунтов, скорости фильтрации грунтовых вод незначительные, отток их в дрены невелик. Малые уклоны поверхности, а следовательно замедлен- 
ное скатывание жидких осадков увеличивают роль инфильтрации и испарения. Режим грунтовых вод данной области формируется в тесной связи с климатическими элементами. Минерализация их повышенная.

Гидрогеологическая область со средней дренированностью грунтовых вод охватывает территорию низкогорного терригенного рода ландшафтов с отметками от 200 до 500-600 м. Сюда же вошли платобазальтовый род ландшафтов и низкогорного терригенного рода ландшафты межгорных котловин. Область характеризуется глубиной эрозионного расчленения 120-300 м (преобладает 200-300 м). Для грунтовых вод этой области характерны более высокие скорости фильтрации, колебания их уровней более динамичные, резкие и кратковременные, а амплитуды значительно больше. грунтовые воды залегают глубже. Благодаря расчлененности рельефа ландшафтов, возрастает скорость скатывания, а следовательно уменьшается инфильтрация атмосферных осадков. Режим грунтовых вод находится в тесной зависимости от хода метеорологических элементов. Минерализация их слабая.

Гидрогеологическая область с сильной дренированностью грунтовых вод охватывает всю территорию горных ландшафтов края выше отметок 500-600 м. Это ландшафты массивно- и расчлененносреднегорные полисубстратные рода, но во всех случаях густота расчленения превышает 1 км на 1 км$^{2}$, достигая в южных районах края значение $1,5-1,8$ км на 1 км$^{2}$. Глубины врезов долин водотоков 500-800 м, что способствует быстрому поверхностному и подземному стоку. Это область самого активного водообмена. Здесь наряду с инфильтрацией достаточно широко проявлена инфлюация, т.е. непосредственное проникновение поверхностных вод в трещиноватую зону скальных пород на участках, где последние не перекрыты рыхлыми мелкообломочными накоплениями Режим грунтовых вод описываемой области характеризуется частыми и очень кратковременными подъемами и спадами уровней. Минерализация их слабая и очень слабая

Гидрогеологические области разделяются на гидрогеологические районы с преимещественным развитием пород того или иного водоносного горизонта или комплекса. При этом в основу выделения подземных вод до четвертичных пород фундамента ландшафтов положена их стратиграфическая принадлежность, а для четвертичного возраста еще и генезис. В результате на территории ландшафтов края выделено 16 водоносных горизонтов и комплексов (фонды «Приморгеология»; Кириллова, 1953 г.).
Поиск закономерностей структуры и организации фундамента ландшафтов с учетом гидрогеологических особенностей и сходства дал возможность выделить 12 водоносных горизонтов и комплексов фундамента ландшафтов.

Водоносный горизонт рыхлых аллювиальных, озерно-аллювиальных и озерных отложений. Водоносный горизонт аллювиальных отложений распространен повсеместно в эрозионно-аккумулятивных долинно-речных ландшафтах по долинам водотоков, но наибольшие площади выходов его на современную поверхность приурочены к эрозионно-аккумулятивному равнинному роду ландшафтов Уссури-Ханкайской равнины (более 8 тыс. км ${ }^{2}$ ). Здесь в составе его преобладают средне- и крупнозернистые пески, часто с гравием и галькой, перекрытые слоем супеси или суглинка. В тесной связи с аллювиальными водовмещающими породами находятся развитые здесь озерно-аллювиальные и озерные отложения сходного состава. Общая мощность разреза 20-50 м. Водоносность пород высокая.

Аллювиальные отложения широких речных долин эрозионноаккумулятивных ландшафтов западного макросклоне Сихотэ-Алиня (Бикин, Большая Уссурка, Малиновка, Уссури с ее притоками, $61-1,62-55,62-63,69-65,70-56$ и др. местности), имеют преобладающую мощность 10-15 м. Отложения представлены, в своей водоносной части, песчано-гравийно-галечниковыми образованиями, перекрытыми сверху слоем глин и суглинков, мощностью до 3 м. Водоносность пород слабая и пестрая. Аллювиальные отложения ландшафтов восточного макросклона Сихотэ-Алиня преимущественно грубообломочные с плохой сортировкой $(61-9,70-51,70=61,85-9,87-40$ и др. местности). Максимальная мощность в низовьях рек достигает 20 м. Покровные глины отсутствуют. Для аллювиальных отложений ландшафтов Приморья в целом характерно уменьшение общей мощности от низовьев к верховьям водотоков, и увеличение в этом же направлении крупности материала при ухудшении сортировки.

Для вод описываемого горизонта свойственна тесная гидравлическая связь с водами поверхностных водотоков. Питание происходит по всей площади выхода за счет инфильтрации атмосферных осадков, подтока воды из трещиноватой зоны коренных пород из русел водотоков в паводковый период. Режим вод свободный, реже слабо напорный, глубина залегания небольшая, движение согласно с продольными уклонами долин. Значительные колебания уровней (до 4-5 м). 
По химическому составу воды первого водоносного горизонта относятся к гидрокарбонатному классу, преимущественно к кальциевой группе, а по соотношению ионов - преимущественно к 1 типу, т.е. характеризуются отношением $\mathrm{HCO}^{3}>\mathrm{Ca}^{2+}+\mathrm{Mg}^{2+}$. Минерализация вод меняется от 0,05 до 0,5 г/л, общая жесткость от 0,6 до 4 мг-экв/л, редко больше. Типичная формула химического состава воды:

$$
\mathrm{M0,213} \frac{\mathrm{HCO}_{3}}{\mathrm{Ca} 44 \mathrm{Mg} 29(\mathrm{Na}+\mathrm{K}) 27}
$$

В аллювиальных водах повсеместно отмечается повышенное содержание железа. Особенно высокие его концентрации, до 10 мг/л, приурочены к Уссури-Ханкайской равнине. Вблизи населенных пунктов и в зоне сельскохозяйственного освоения водь загрязнены органикой, химическими мелиорантами, гербицидами, пестицидами, а в зоне рисосеяния и дефолантами. В населенных пунктах, кроме того, аллювиальные воды бывают загрязнены синтетическими моющими средствами, аммиаком, нитритами Повсюду в зоне хозяйственного освоения и вблизи автомобильных дорог в водах фиксируется техногенный свинец.

Водоносный комплекс рыхлых морских и аллювиально-морских отложений. Комплекс имеет ограниченное распространение преимущественно на западном и восточном берегах залива Петра Великого, в изголовьях бухт и в приустьевых частях долин относительно крупных рек побережья Японского моря (59a-1, 60а-1 59-1, 59-1, 59-5, 59-6 и др. местности). Породы комплекса, слагающие прибрежные низменности, представлены разнозернистыми песками, иловатыми супесями и суглинками. Отложения террас, пляжей и дельт рек открытого побережья состоят из песков, галечников с валунами и гравием. Питание водоносного комплекса происходит за счет инфильтрации атмосферных осадков, подтока подземных вод из других водоносных горизонтов и комплексов, а также за счет речных вод. Движение грунтового потока направлено в сторону моря. Глубина залегания воды $1-7$ м (редко 15 м), отмечаются напорные воды с величиной напора до 4-8 м и даже более. Водоносность комплекса пестрая, режим непостоянный. Уровень воды испытывает значительные колебания в течение года (в пос. Самарга до 2 м).

По химическому составу воду морских и аллювиально-морских отложений относят к гидрокарбонатному и, реже, к хлоридному классам. По содержанию катионов преобладают воды натриевой и кальциевой групп, по соотношению ионов они относятся к 1 типу $\left(\mathrm{HCO}_{3}^{-}>\mathrm{Ca}^{2+}+\mathrm{Mg}^{2+}\right)$, реже к III типу $\left(\mathrm{HCO}_{3}{ }^{-}+\mathrm{SO} \frac{2}{4}{ }^{-}>\mathrm{Ca}^{2+}+\mathrm{Mg}^{2+}\right)$. Верхняя часть водоносного комплекса обычно хорошо промыта и воды здесь в поверхностном слое, как правило, пресные даже у самого берега моря. Но в горизонтах, расположенных ниже уровня моря, минерализация и жесткость заметно возрастает порой на значительном удалении от моря (несколько сотен метров и даже километры от береговой черты).

Воды спорадического распространения делювиальных, элювиальных, нерасчлененных склоновых и оползневых образований ландшафтов. Воды формируются обычно в супесях и суглинках с большим процентным содержанием дресвы, щебня и глыб. Неоднородность разрезов по мощности и невыдержанность состава рыхлых накоплений по площади, создают пеструю линзообразную картину распределения заключенных в них подземных вод. Сравнительно водообильными являются делювиальные и элювиальные образования на гранитах. Мощность их в низкогорном терригенном роде ландшафтов может достигать 5-25 м и более. В расчлененносреднегорном полисубстратном роде ландшафтов мощность делювия редко превышает 3 м, а элювия - 5 м. Исключение представляет платобазальтовый род ландшафтов, где мощность коры выветривания может достигать 6 м и более.

Воды нерасчлененных склоновых образований горных ландшафтов связаны с дресвяно-суглинистыми, щебенисто-суглинистыми и глыбово-щебенистыми накоплениями солифлюкционных террас, склоновыми, шлейфами промежуточной аккумуляции (осовами), оползневыми накоплениями. Они более всего распространены у подножия склонов. Мощность их может достигать первых десятков метров (до 30 м). Спорадические линзовидные скопления подземных вод в этих накоплениях формируются за счет инфильтрации атмосферных осадков, конденсации атмосферной влаги и подтока воды из верхней трещиноватой зоны коренных пород. Ввиду активного и быстрого водообмена воды имеют слабую минерализацию (не более 0,1 г/л) и по составу относятся к гидрокарбонатному классу, кальциевой группе.

Водоносный комплекс неогеновых базальтов. Водоносный комплекс пространственно связан с платобазальтовым родом ландшафтов с эффузивными полями (плато) базальтов, андезитобазальтов, туфов, осадочно-вулканических и пиракластических 
продуктов извержений неогеновых вулканов фундамента ландшафтов. Поля развития этих пород фундамента довольно широко распространены по всему Приморью. Наиболее обширные из них расположены в бассейне р. Самарги, в верхнем течении р. Бикин, на водоразделе рек Артемовка и Илистая, по правым притокам р. Раздольная.

Подземные воды приурочены к трещиноватым разностям базальтов и внутриформационным горизонтам рыхлых пирокластических пород. Число водоносных горизонтов может достигать 4-7 и более. Мощность их от первых метров до 70-100 м. Водообильность отдельных горизонтов высокая (дебиты скважин до 10 л/сек и даже более). Питание подземных вод описываемого комплекса происходит за счет инфильтрации атмосферных осадков, конденсации влаги воздуха, грунтовых вод аллювия, подтока из трещиноватой зоны подстилающих пород. Разгрузка происходит в речную сеть. В краевых частях плато распространенной формой разгрузки являются родники.

Колебания уровней подземных вод в течение года составляют $2-3$ м. Температура изменяется в течение года в пределах $3-6^{\circ} \mathrm{C}$. Химический состав и минерализация в течение года изменяются очень мало. По химическому составу воды описываемого комплекса относятся к гидрокарбонатному классу, преимущественно кальциевой и магниевой группам, по соотношению ионов к 1 типу, т.е. $\mathrm{HCO}_{3}^{-}>\mathrm{Ca}^{2+}+\mathrm{Mg}^{2+}$. Минерализация вод от сотых долей до 0,3 г/л, общая жесткость не превышает 3 мг-экв/л.

Типичная формула химического состава вод базальтов:

$$
M_{0,202} \frac{\mathrm{HCO}_{3} 95}{\mathrm{Ca} 45 \mathrm{Mg} 42(\mathrm{Na}+\mathrm{K}) 13} .
$$

Водоносный комплекс рыхлых накоплений неогена. Развит в югозападной и западной частях Приморья (67-2, 75-17, 75-23 и др. местности). Пространственно связан с рыхлыми накоплениями неогенового возраста сложного генезиса (усть-суйфунская, суйфунская свиты и их аналоги). Это - аллювиальные, озерно-аллювиальные отложения и накопления временных катастрофических потоков, сопровождающих вулканические извержения. Водоносные горизонты комплекса приурочены к прослоям песков, гравийников, галечников среди глинистых водоупоров. На площадях, где водовмещающие породы выходят на поверхность, воды имеют безнапорный характер. Глубина залегания воды на этих площадях зависит от относительного превышения их над местными дренами и обычно колеблется в пределах 10-50 м, а иногда они сдренированы полностью. В случае перекрытия сверху глинами, воды приобретают напорный характер и разгружаются путем перетока, в вышележащие слои или на поверхность. Таковы, к примеру, источники питания рек Репьевка, Раковка, Крестьянка и др. на площади Южно-Приморского сложного артезианского бассейна.

Амплитуда колебания уровней на безнапорных участках в годовом разрезе от 1 до 3 м всецело зависит от хода влажности и выпадающих осадков. Дебиты скважин до 15 л/сек. По химическому составу воды комплекса рыхлых накоплений неогена относятся к гидрокарбонатному классу, преимущественно к кальциевой, реже магниевой группам, по соотношению ионов - к 1 типу, т.е. $\mathrm{HCO}_{3}^{-}>\mathrm{Ca}^{2+}+\mathrm{Mg}^{2+}$. Минерализация воды не превышает 0,5 г-л, общая жесткость 1-3 мг-экв/л, содержание железа в воде, как правило, не превышает 1,5 мг/л.

Типичная формула химического состава воды для вод суйфунского горизонта:

для усть-суйфунского:

$$
\text { м0,246 } \frac{\mathrm{HCO}_{3} 92}{\mathrm{Ca} 49 \mathrm{Mg} 37(\mathrm{Na}+\mathrm{K}) 14}
$$

$$
{ }_{M} 0,136 \frac{\mathrm{HCO}_{3} 92}{\mathrm{Ca} 41(\mathrm{Na}+\mathrm{K}) 30 \mathrm{Mg} 25} .
$$

Водоносный комплекс рыхлых накоплений палеогена. В этот комплекс объединены майтунская, угловская и надеждинская свиты палеогена, а также пространственно и генетически с ними связанные миоценовые отложения (усть-давыдовская свита) фундамента ландшафтов эрозионно-аккумулятивного равнинного и долинно-речного рода (75-15, 75-23 и др. местности). Комплекс развит в западных и юго-западных районах края. Он выходит на поверхность из под более молодых рыхлых накоплений и базальтов в краевых частях впадин или плато базальтов. Но во всех случаях комплекс приурочен преимущественно к отрицательным формам рельефа. Водовмещающие и водоупорные породы комплекса представлены переслаиванием аргиллитов, алевролитов, уплотненных песков, лигнитов, туффитов, уплотненных гравийников и галечников. Глубина залегания водоносных горизонтов комплекса определяется условиями залегания и мощностью перекрывающих толщ. Воды напорные. Величина напора от первых метров до 150-300 м. Водоносность пестрая. Дебиты скважин от первых десятых до 10 л/сек, редко больше. 
Питание водоносных горизонтов комплекса осуществляется, в основном, за счет подтока трещинных вод с окружающих горных сооружений, фильтрации из перекрывающих толщ и инфильтрации атмосферных осадков на участках выходов пород на дневную поверхность. Вероятно, определенное значение имеют подземные воды зон тектонических нарушений, поскольку в ряде случаев скважинами вскрываются минерализованные воды. Уровенный режим, химизм и температура воды водоносных горизонтов комплекса отличаются большой устойчивостью в годовом разрезе и мало зависят от атмосферных осадков. По химическому составу воды комплекса относятся к гидрокарбонатному классу, натриевой и реже кальциевой группам, по соотношению ионов - к 1 типу, т.е. характеризуются соотношением $\mathrm{HCO}_{3}^{-}>\mathrm{Ca}^{2+}+\mathrm{Mg}^{2+}$. Минерализация вод чаще всего не превышает 0,5 г/л, общая жесткость менее 3 мг-экв/л.

Типичная формула химического состава:

$$
M 0,292 \frac{\mathrm{HCO}_{3} 07}{(\mathrm{Na}+\mathrm{K}) 56 \mathrm{Mg} 2 \mathrm{Ca} 20} .
$$

В глубоких скважинах Артемо-Тавричанской впадины, расположенных вблизи моря, встречаются воды хлоридного класса, натриевой группы с общей минерализацией превышающей 5 г/л. В шахтных водах в пределах этой впадины также отмечаются повышенные содержания хлоридов, сульфатов и более высокая минерализация (1-5 г/л).

Воды эффузивных пород палеогена и верхнего мела. Эффузивы фундамента преимушественно горных ландшафтов представлены лавами кислого и среднего состава с пачками пирокластических и реже туфогенно-осадочных пород. Воды в этих породах формируются в зоне экзогенной трещиноватости и в трещинных зонах, связанных с тектоническими нарушениями и интрузивными контактами. Экзогенная трещиноватость в эффузивах относительно слабая. Ширина трещин от первых десятых долей до 10-20 мм, расстояние между ними от первых сантиметров до 1 м и даже более. С глубиной количество трещин и их ширина быстро сокращаются и на глубинах 30-60 м трещиноватость практически исчезает.

Коэффициенты фильтрации эффузивных пород от 0,004 до 5,4 м/сутки. Воды в большинстве случаев безнапорные грунтового типа. Глубина залегания их 2-12 м в долинах и 4-30 м в нижних частях склонов. Вершины, водораздельные гребни и верхние части склонов гор постоянных запасов воды в зоне экзогенной трещиноватости фактически не содержат.

Питание водоносного комплекса происходит, в основном, за счет атмосферных осадков, подтока из других комплексов и конденсации водяных паров из воздуха. Инфильтрация атмосферных осадков тесно связана с залесенностью, задернованностью склонов, и хорошей водопроводимостью склоновых накоплений Разгрузка подземных вод комплекса осуществляется в долины водотоков, и реже в виде родников на перегибах склонов, направление движения совпадает с направлением поверхностного стока. В поведении уровней подземных вод отмечается связь с режимом атмосферных осадков и влажностью воздуха, причем эта связь тем теснее и заметнее, чем выше по склону расположена наблюдательная скважина. Амплитуда колебания уровней может достигать 6 м. Минерализация подземных вод в течение года изменяется очень мало. Увеличение ее в зимний период, по сравнению с летним, происходит всего на 10-30 мг/л. Удельные дебиты скважин, вскрывающих подземные воды эффузивов 0,05-0,5 л/сек, редко больше. Скважины, вскрывающие воды тектонических зон трещиноватости в эффузивах имеют дебиты до 5 л/сек, но могут быть и безводными.

По химическому составу воды эффузивных пород почти все относятся к классу гидрокарбонатных, по катионному составу к группе кальциевых, реже - натриевых и магниевых, по соотношению анионов и катионов - к 1 типу, т.е. $\mathrm{HCO}_{3}^{-}>\mathrm{Ca}^{2+}+\mathrm{Mg}^{2+}$. Минерализация вод не превышает 0,5 г/л. Общая жесткость не выше 5 мг-экв/л (чаще до 1,5 мг-экв/л).

Типичная формула химического состава:

$$
\mathrm{M} 0,441 \frac{\mathrm{HCO}_{3} 95}{\mathrm{Ca} 52(\mathrm{Na}+\mathrm{K}) 26 \mathrm{Mg} 22}
$$

Воды мезозойских отложений. В этот комплекс включены осадочные отложения и внутриформационные вулканогенные образования верхнего и нижнего мела, юры и триаса коренного фундамента горных ландшафтов. Они представлены песчаниками, алевролитами, аргиллитами, глинистыми сланцами, кремнями, туфами, туфопесчаниками, реже конгломератами, гравелитами, известняками, каменными углями, порфиритами и базальтоидами.

Зона экзогенной трещиноватости имеет повсеместное развитие и проникает вглубь в песчаниках и конгломератах на 20-40 м, 
в алевролитах - 10-25 м, аргиллитах - до 20 м. Глубина залегания подземных вод от 0,5 до 50 м (чаще 5-12 м). Воды, как правило, безнапорные. Дебиты скважин от 0,01 л/сек до 2 л/сек и даже более (в зависимости от пористости пород и их раздробленности). Этими же причинами определяются коэффициенты фильтрации, изменяющиеся от первых сантиметров до 10-15 м/сутки.

По химическому составу воды мезозойских отложений, как правило, относятся к классу гидрокарбонатных, и только единичные анализы указывают на принадлежность их к классу сульфатных. По преобладанию катионов воды принадлежат к группе кальциевых и реже натриевых вод. По соотношению анионов и катионов преобладают воды 1 типа, т.е. $\mathrm{HCO}_{3}^{-}>\mathrm{Ca}^{2+}+\mathrm{Mg}^{2+}$. Минерализация гидрокарбонатных вод менее 0,5 г/л, редко до 0,7 г/л, жесткость $1-4$, реже до 8 мг-экв/л. Типичная формула состава:

$$
M_{0.341} \frac{\mathrm{HCO}_{3} 93}{\mathrm{Ca} 55(\mathrm{Na}+\mathrm{K}) 24 \mathrm{Mg} 21} .
$$

Воды известняков, вскрытых глубокими скважинами на Николаевском полиметаллическом месторождении гидрокарбонатные и гидрокарбонатно-сульфатные, натриевые или кальциевые с минерализацией до 1,2 г/л. Сульфат-ион часто в значительных количествах присутствует в водах рудных полей сульфидных и угольных месторождений. В скважинах, пробуренных вблизи морского берега, встречаются воды хлоридного класса.

Воды верхне- и среднепалеозойских отложений. Отложения этого комплекса представлены чередованием терригенных и вулканогенно-осадочных образований фундамента горных ландшафтов (песчаники, алевролиты, аргиллиты, глинистые сланцы, туфопесчаники, туффиты, туфы, спилиты, эффузивы кислого и среднего состава, кремни, известняки, конгломераты).

Водоносность пород, как и в других, сходных по литологии комплексах, связана с зонами экзогенной и тектонической трещиноватости, а в карбонатных - еще и с карстовыми полостями. Мощность экзогенной трещиноватости в зависимости от состава пород и положения в рельефе меняется от 20-40 до 50-70 м. Широко проявлены процессы кольматажа трещин глинистыми продуктами выветривания самих пород. Воды, в большинстве своем, относятся к классу грунтовых, но встречаются и напорные воды (на участках, где распространены полигенетические глины педиментной природы). Глубина залегания подземных вод в нижних частях склонов 1-10 м (чаще 2,5-5 м), на возвышенных частях - 15-22 м, водоразделы часто бывают практически безводны. Водоносность пород пестрая. Наименее водоносны сланцы и порфириты, высокой водоносностью характеризуются известняки и трещиноватые песчаники. Режим подземных вод зависит от атмосферных осадков и сезонов года. Колебания уровней достигают 2-5 м. По химическому составу воды относятся к классу гидрокарбонатных, по катионному составу - к группе кальциевых, реже - натриевых, по соотношению анионов и катионов к 1 типу, т.е. $\mathrm{HCO}_{3}^{-}>\mathrm{Ca}^{2+}+\mathrm{Mg}^{2+}$. Минерализация вод не менее 0,5 г/л, общая жесткость 0,8-8,3 мг-экв/л.

Формула химического состава:

$$
\mathrm{M} 0,142 \frac{\mathrm{HCO}_{3} 89}{\mathrm{Ca} 57 \mathrm{Mg} 22(\mathrm{Na}+\mathrm{K}) 19} .
$$

Воды нижнепалеозойских и протерозойских отложений. Подземные воды этих отложений распространены в пределах Ханкайского массива и приурочены к вещественным комплексам фундамента ландшафтов эрозионно-аккумулятивного равнинного рода. Водовмещающие породы представлены различными по составу сланцами, песчаниками, конгломератами, алевролитами, кварцитами, амфиболитами, гнейсами. Существенную роль в разрезе играют известняки, доломиты, мраморы. Все толщи сложно дислоцированы, разбиты тектоническими нарушениями и прорваны разнообразными интрузиями гранитов и габброидов. В рельефе породы образуют, обычно, древние эрозионные поверхности, пологие холмы и низкие горы. Зона экзогенной трещиноватости в породах комплекса достигает 60-70 м, но большинство трещин заполнены тонкими продуктами выветривания самих пород. Это определяет слабую обводненность сланцевых и песчаниковых толщ. Значительно более обводнены карбонатные породы, в которых развиты карстовые воды. В сильно закарстованных разностях известняков дебиты скважин могут достигать 50 л/сек и даже более, но при отсутствии восполнения со стороны аллювиальных горизонтов, наблюдается быстрая сработка статических запасов. Режим подземных вод комплекса находится в тесной связи с атмосферными осадками. Глубины залегания 2-10 м, колебания уровней по сезонам года 2-4 м.

Воды относятся к классу гидрокарбонатных, по катионному составу - к группе кальциевых, реже натриевых. Минерализация 
обычно не превышает 0,5 г/л, жесткость менее 3,5 мг-экв/л, лишь воды известняков имеют минерализацию 0,5-0,7 г/л и жесткость до 7,5 мг-экв/л. Формула химического комплекса:

$$
M_{0,409} \frac{\mathrm{HCO}_{3} 56}{\mathrm{Ca} 70 \mathrm{Mg} 25} .
$$

Подземные воды гранитоидов. Гранитоидные породы фундамента ландшафтов в Приморском крае распространены довольно широко (55-40, 56-17, 56-18 и др. местности). Повсеместно в них развиты коры выветривания и зона экзогенной трещиноватости. Мощность кор колеблется от первых метров до 20-30 м и даже более. Зона экзогенной трещиноватости может проникать на глубину до 70 м, причем эффективная ее часть с приоткрытыми трещинами может составлять 50-60 м. Кроме зоны экзогенной трещиноватости, в гранитоидах широко развиты линейные зоны разрывов различной ориентировки, иногда прослеживающиеся на глубину до 100 м, имеющие хорошие коллекторские свойства и значительную протяженность.

Гранитоидные массивы, слагающие положительные формы рельефа, имеют небольшую мощность водоносной зоны. Ниже по склону, в связи с более близким залеганием грунтовых вод от поверхности земли, мощность обводненной части их увеличивается, достигая максимальной величины в нижних частях склонов и под долинами водотоков. Если долинные накопления водоносны, то устанавливается, как правило, тесная гидравлическая связь, и образуется единый водоносный безнапорный горизонт на склонах гор. Подземные воды гранитов также, обычно, имеют свободный режим и вскрываются на глубинах порядка 10-30 м. В тех случаях, когда граниты перекрываются водоупорными образованиями (делювиальные или полигенетические глины, оползневые, солифлюкционные, пролювиальные, гравитационные накопления и т.п.), в верхней трещиноватой зоне их формируются напорные подземные воды. Величина напора зависит от гипсометрического положения участка, от мощности и фильтрационных свойств, перекрывающих граниты водоупорных пород, количества осадков и т.д., но обычно она редко когда превышает 15-20 м. В некоторых пунктах пьезометрический уровень выше поверхности земли.

Сравнительно большое количество родников в поле развития гранитов, густая и разветвленная гидросеть, четко выраженная пойма долин водотоков и отсутствие больших паводков, все это свидетельствует об интенсивной инфильтрации атмосферных осадков медленной и равномерной водоотдаче пород.

Режим подземных вод гранитоидов обнаруживает тесную связь с осадками. Амплитуда колебания уровней в годовом разрезе достигает 6 м на приводораздельных участках, и 0,5-1,0 м в долинах рек.

Воды гранитоидов всех возрастных групп являются пресными. По химическому составу они относятся, как правило, к гидрокарбонатному классу, по катионному составу к группам кальциевых и реже натриевых вод. По соотношению анионов и катионов они относятся к 1 типу, т.е. характеризуются отношением $\mathrm{HCO}_{3}^{-}>\mathrm{Ca}^{2+}+\mathrm{Mg}^{2+}$. Минерализация воды в большинстве случае не превышает 0,5 г/л, жесткость до 3, реже до 6 мг-экв/л. Формула химического состава воды гранитов:

$$
M_{0,201} \frac{\mathrm{HCO}_{3} 92}{\mathrm{Ca} 66(\mathrm{Na}+\mathrm{K}) 18 \mathrm{Mg} 16} \text {. }
$$

Подземные воды габрроидов. Эти подземные воды пользуются незначительным распространением на территории горных ландшафтов края, главным образом в зоне Краевого Сихотэ-Алинского офиолитового шва (29-6, 29-8 и др. местности.). Приурочены они к верхней трещиноватой зоне скальных пород, мощность которой меняется от 10 до 50 м в зависимости от положения в рельефе и характера эндогенной трещиноватости массивов. Ширина трещин от десятых долей до 304 мм. Многие трещины заполнены глинистыми продуктами выветривания. Глубина залегания подземных вод в габброидах от 3 до 30 м. Воды в большинстве своем свободные и только в нижних частях склонов, где развиты водоупорные перекрывающие накопления, они переходят в напорные. Массивные разности габбро, подобно аналогичным гранитам, характеризуются слабой обводненностью. В зонах же разрывных дислокаций открытого типа водообильность бывает сравнительно высокой, и прослеживаются обводненные породы до глубины 120 м и даже более.

Воды габброидов, как правило, относятся к классу гидрокарбонатных, по катионному составу к группам кальциевых, реже натриевых, по соотношению катионов и анионов - к 1 типу, т.е. характеризуется отношением $\mathrm{HCO}_{3}^{-}>\mathrm{Ca}^{2+}+\mathrm{Mg}^{2+}$. Воды пресные, общая минерализация их обычно не превышает 0,3 г/л, жесткость $-1,5-2,6$ мг-экв/л, иногда до 4 мг-экв/л. Типовая формула химического состава: 


$$
M_{0,152} \frac{\mathrm{HCO}_{3} 88}{\mathrm{Ca} 52 \mathrm{Mg} 32(\mathrm{Na}+\mathrm{K}) 16} .
$$

В заключение этого раздела следует сказать, что на основе анализа гидрогеологических особенностей ландшафтов Приморья установлены некоторые региональные особенности. По родам ландшафтов с преимущественным развитием пород того или иного водоносного горизонта или комплекса наблюдается разделение по условиям увлажнения и питания на три группы: избыточного, достаточного, умеренного питания грунтовых вод:

- избыточного питания: массивно - и среднегорно-расчлененный полисубстратные, низкогорный терригенный роды (побережье Японского моря, южные, центральные, а на севере и западные районы горных ландшафтов Сихотэ-Алиня). Это около $70 \%$ всей территории края;

- достаточного питания: эрозионно-аккумулятивный равнинный (низинные части долин рек Уссури, Сунгач, Илистая, Раздольная) и низкогорный терригенный роды (западные отроги Сихотэ-Алиня);

- умеренного питания: низкогорный терригенный и вулканогенно-терригенный (северная часть Восточно-Маньчжурских гор) и эрозионно-аккумулятивный равнинный роды ландшафтов (Приханкайская низменность).

Питание всех подземных вод осуществляется за счет атмосферных осадков и происходит, в основном, в пределах горного класса ландшафтов. Из всего количества воды, просачивающейся в грунт, около $80 \%$ очень быстро стекает в виде приповерхностного (грунтового) стока. Оставшаяся часть, пройдя зону аэрации, достигает уровня подземных вод, пополняя их динамические запасы. Именно динамические запасы, поскольку подземные воды, приуроченные лишь к верхней трещиноватой зоне мощностью до 60 м (редко более), активно мигрируют в условиях расчлененного рельефа. При отсутствии восполнения, запасы подземных вод в горных ландшафтах быстро истощаются. В этом причина резких колебаний их уровня. Часть подземных вод горных районов перетекают в межгорные и предгорные впадины, пополняя запасы в артезианских бассейнах, которые характеризуются замедленным водообменном и более стабильными водными запасами. Этой динамикой определяется активная роль подземных вод в общей схеме миграции вещества в ландшафтах.
На основе анализа гидрогеологических особенностей ландшафтов устанавливается значимая роль таких параметров, как питание и увлажненность субстрата ландшафтов, в миграции, процессах протекающих в геосистемах. Во взаимосвязи и взаимообусловленности с этими водными компонентами проявляется физическое и химическое выветривание, миграция вещества и др. значимые для ландшафтов процессы. В результате в зависимости от высотности и поясности в связи с динамикой водных систем формируются различные по составу, генезису рыхлые вещественные комплексы субстрата ландшафтов. Например, на вершинах, водоразделах и приводораздельных частях склонов зоны развития ландшафтов массивно-среднегорного полисубстратного рода интенсивно идут процессы физического выветривания и курумовый транзит обломочного материала. Это приводит преимущественно к глыбовой дезъинтеграции скальных пород. Мелкозем формируется в весьма незначительных количествах, почвы имеют неполный профиль или отсутствуют вообще. Для нижних по профилю частей склонов расчленено-среднегорного полисубстратного рода ландшафтов более характерна дезъинтеграция обломков, характеризующая глубокую стадию мобилизации минерального вещества вплоть до распада его на минеральные компоненты. В зоне ландшафтов низкогорного терригенного рода, где скорость транзита заметно ниже, происходят при участии воды более глубокие химические превращения рыхлых склоновых отложений.

Поэтому, при изучении континентально-приокеанических ландшафтных систем, выявлении закономерностей их возникновения, развития во времени и пространстве, необходимо тщательно изучать сопряженные с ними в пространстве и времени водные и эрозионно-денудационные системы. Особенно это относится к территориям сопряжения горного и равнинного классов ландшафтов. Гидрогеологические особенности представляются в этом случае важнейшими компонентными основами изучения ландшафтных геосистем и их функционирования.

\section{Контрольные вопросы}

1. Охарактеризуйте распределение в Приморье стока во времени и пространстве.

2. Охарактеризуйте паводочный режим рек Приморья.

3. Охарактеризуйте типы колебания уровней рек в летний период на реках края.

4. Раскройте понятие верховодка. 
5. Охарактеризуйте основные особенности гидрогеологического режима подземных вод.

6. Раскройте понятие - зона избыточного питания грунтовых вод.

7. Раскройте понятие - зона достаточного питания грунтовых вод.

8. Раскройте понятие - зона умеренного питания грунтовых вод?

9. Раскройте понятие - гидрогеологическая область со слабой дренированностью грунтовых вод.

10. Раскройте понятие - гидрогеологическая область со средней дренированностью грунтовых вод.

11. Раскройте понятие - гидрогеологическая область с сильной дренированностью грунтовых вод.

12. Какие и сколько водоносных горизонтов и комплексов фундамента ландшафтов выделяется в Приморье?

13. Охарактеризуйте особенности водоносного горизонта рыхлых аллювиальных, озерно-аллювиальных и озерных отложений.

14. Охарактеризуйте особенности водоносных горизонтов комплекса неогеновых базальтов, рыхлых накоплений неогена и палеогена, эффузивных и других разновозрастных пород.

15. Охарактеризуйте общие гидрогеологическими особенностями ландшафтов Приморья.

\section{Лекция 7}

\section{РЕГИОНАЛЬНАЯ ПРИРОДНО-КОМПОНЕНТНАЯ СПЕЦИФИКА ПРИМОРЬЯ (ПочвЫ, растиТельНосТЬ)}

\section{1 Почвы}

Многообразие природных обстановок Приморского края предопределило формирование различных типов почв, детальные описания которых имеются в литературе, а пространственные особенности распространения показаны на картах (рис. 8).

Горно-таежные бурые почвы. На юге Сихотэ-Алиня они занимают верхний пояс гор, за исключением наиболее высоких отдельных вершин, где под стелющимися лесами кедрового стланика развиты сухоторфянистые почвы, а еще выше горно-тундровые. K северу нижняя граница горно-таежных бурых почв постепенно снижается и на севере Сихотэ-Алиня сливается с широтной зоной аналогичных почв. Горно-таежные бурые почвы характеризуются довольно разнообразным морфологическим строением профиля.

В одних случаях они имеют иллювиальный горизонт с высоким содержанием гумуса, в других - оглеенный или ожелезненный. Почти всегда в этих почвах самый верхний горизонт представлен слаборазложившейся лесной подстилкой рыхлого сложения мощностью до 5-6 см, пронизанной корнями. В нижней части она обычно более гумифицирована. Под темнохвойными лесами южного и среднего Сихотэ-Алиня запасы лесной подстилки в период максимального накопления достигают 20 т/га и более, что соответствует 7-10-летнему количеству опада [145].

Среди горно-таежных бурых почв наиболее часто встречаются горно-таежные бурые иллювиально-гумусовые и горно-таежные охристо-бурые почвы.

Горно-таежные бурые иллювиально-гумусовые почвы формируются под папоротниковыми и зеленомошными пихтово-еловыми лесами горно- темнохвойного подкласса ландшафтов. Они имеют отчетливо дифференцированный профиль. Лесная подстилка 


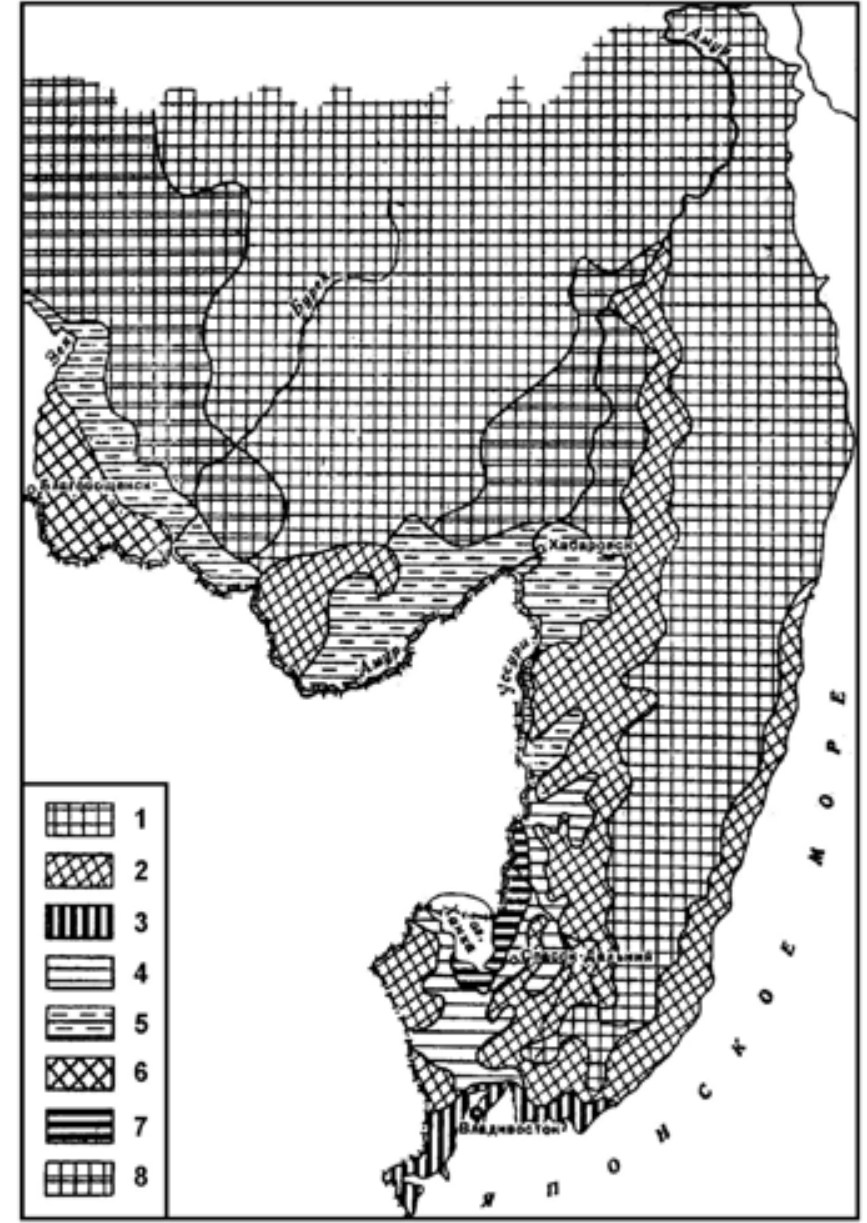

Puc. 8. Схематическая карта распределения почв на юге Дальнего Востока

1 - горные буро-таёжные: типичные, иллювиально гумусовые, охристые; буро-таёжные глеевато- и глеево-оподзоленные на базальтовых плато; 2 - горно-лесные бурые: типичные и оподзоленные; 3 - горнолесные бурые и желто-бурые; желто-бурые отбеленные; 4 - бурые отбеленные, бурые глеевато-отбеленные, лугово-бурые отбеленные; 5 - бурые глеево-отбеленные; лугово-бурые глеево-отбеленные; луговые глеевые типичные, отбеленные, оподзоленные; болотные; 6 - луговобурые черноземовидные; 7 - луговые глеевые: типичные, отбеленные, оподзоленные, осолоделые; 8 - бурые лесные и буро-таёжные типичные, глеевато- и глеево-оподзоленные полуразложившаяся, рыхлая, толшиною 2-5 см. Гумусовый горизонт, мощностью обычно не более $10 \mathrm{cм}$, содержит большое количество полуразложившихся и свежих растительных остатков, рыхлый. Минеральная масса в горизонте серого или коричневосерого цвета скреплена мелкими корнями в непрочные комочки. Глубже идет крупитчатый рыхлый коричневый иллювиальный горизонт. Мелкозем буро - таежных почв представлен преимущественно суглинками с невысоким содержанием ила при некотором максимуме его в иллювиальном или гумусовом и иллювиальном горизонтах.

Горно-таежные охристо-бурые почвы развиты под горными лиственничниками с подлеском из рододендрона, можжевельника и других сухо- и светолюбивых кустарников. Характеризуются они маломощным профилем. Особенно маломощные и грубоскелетные примитивно аккумулятивные почвы приурочены к наиболее сухим склонам южной экспозиции с лишайниковыми лиственничниками [63]. Сплошной почвенный покров по таким склонам, как правило, отсутствует. Участки с более или менее развитым почвенным покровом чередуются с каменистыми осыпями и скальными обнажениями.

Наиболее развитые горно-таежные охристо-бурые почвы имеют мощность 50-70 см. На поверхности залегает лесная подстилка (3-4 см), гумусовый горизонт (3-5 см) буровато-серый с большим количеством свежих и полуразложившихся растительных остатков Переход в иллювиальный горизонт постепенный. Последний чаще всего имеет яркий охристый цвет иногда с палевым или коричневатым оттенком. На глубине 40-60 см иллювиальный горизонт постепенно сменяется щебенистым суглинком подпочвенного слоя рыхлых накоплений.

В пределах ареала горно-таежной растительности в ландшафтах развиты различные гидроморфные торфянисто - и торфяно-глеевые почвы. Особенно значительные их площади распространены в северной части края под изреженными елово-пихтовыми зеленомошными лесами с глубоким сезономерзлым слоем почвогрунтов. В этих почвах под слоем зеленого мха мощностью 5-6 см залегает грубогумусовый (торфянистый) горизонт буровато-коричневого цвета мощностью 10-20 см. Ниже следует перегнойный горизонт темно-серого или даже черного цвета, бесструктурный, сырой. Глубже идет горизонт черного цвета с ясно выраженной зернистой структурой, к низу постепенно светлеющий и окрашенный в коричневые (охристые) тона. С глубины 55-65 см 
почва приобретает цвет материнской рыхлой породы. Именно на этой глубине (50-60 см) наиболее долго (до июля - августа) сохраняется сезонная мерзлота или даже мерзлотные перелетки.

Под хвойно-широколиственными и широколиственными лесами в горно-лесных смешанно-широколиственных ландшафтах формируются горно-лесные и лесные бурые почвы. На юге Приморья они простираются до высоты 800-900 м над уровнем моря. При движении на север верхняя граница их распространения постепенно снижается и на севере края они полностью исчезают. На низких террасах равнин эти почвы распространены повсеместно, занимая микровозвышения рельефа (релки).

Ареал горно-лесных бурых почв довольно обширный, диагностические показатели их разнородны. В северных районах и у верхней границы пояса они сменяются различными горно-таежными бурыми почвами. В узкой прибрежной полосе по восточным склонам южного Сихотэ-Алиня под обедненными дубовыми лесами развиты своеобразные коричнево-бурые почвы.

Все горно-лесные бурые почвы существенно различаются по степени развитости профиля, его мощности, химизму и механическому составу. Наиболее представительные из них - горно-лесные и лесные бурые почвы.

Горно-лесные бурые почвы приурочены к верхней части вертикального пояса лесных почв. На более низких уровнях они отмечаются по гребням водоразделов, крутым склонам и другим местоположениям.

Верхний слой почвы представлен лесной подстилкой или органоперегнойными остатками растительного опада мощностью 1-3 см. В хвойно-широколиственных лесах южного Приморья с участием ели аянской запасы подстилки не превышают 16-20 т/га. Годичная масса опада составляет 3-4 т / га, из них $70 \%$ приходится на осень. При максимальном количестве подстилки ранней весной запасы ее уменьшаются с мая по сентябрь на 20-50\%.

Все вышесказанное о строении и механическом составе почв относится к идеальному случаю ненарушенных условий их формирования. Поскольку в крае широко проявлены процессы интенсивного перемещения склоновых накоплений в виде солифлюкции, склонового крипа, осовов, оплывин, оползней и т. п, то, вполне естественно, наблюдаются более сложные профили с погребенными или срезанными горизонтами.

Лесные бурые почвы на аллювиальных отложениях террас распространены повсеместно в долинных ландшафтах крупных 102 рек по сухим релкам, сложенным рыхлыми породами легкого механического состава, растительность на этих почвах представлена чаще всего дубовыми и дубово-березовыми лесами. Содержание гумуса в целинных почвах 6-15\%, в пахотных снижается до 2,5-3\%, в результате чего бурый цвет превращается в светло - бурый.

Механический анализ почв показывает высокое содержание илистой фракции в верхних и средних частях профиля до глубин 30-50 см при общей мощности 110-200 см.

Почвы под широколиственными и хвойно-широколиственными лесами мелкосопочного полисубстратного и эрозионно-аккумулятивного равнинного родов ландшафтов имеют в целом бурый цвет, на фоне которого выделяется аккумулятивно-гумусовый горизонт серого цвета. На красноцветных корах выветривания нижняя часть почвенного профиля обычно кирпично-красного цвета. Эти почвы отнесены к бурым отбеленным (бывшие буроподзолистые) [64].

Бурые отбеленные типичные почвы распространены в пределах ландшафтов Уссури-Ханкайской равнины, в мелкосопочных полисубстратных ландшафтах ее мелкосопочного обрамления и в некоторых межгорных впадинах. Формируются они под широколиственными и дубовыми изреженными лесами и под порослевыми древесно-кустарниковыми зарослями на глинистых корах выветривания.

Целинные почвы этого типа имеют гумусовый горизонт (7-10 cм) непрочнокомковатой структуры, пронизанный мелкими корнями. Он постепенно переходит в белесый горизонт мощностью 20-30 см, который часто имеет тонкослоистое (листоватое) сложение и содержит большое количество марганцево-железистых конкреций. Иногда этот горизонт разбит на всю глубину трещинами, придающими ему столбчатое сложение. Иллювиальный горизонт имеет темно-бурый цвет, призматически-слоистую структуру. Общая мощность почвенного слоя 140-190 см. Переход в почвообразующую породу постепенный.

Почвы разнотравно-злаковых остепненных лугов и редколесий по суходольным лугам. Разнотравно-злаковые остепненные луга и редколесья по суходольным лугам приурочены в основном к террасам среднечетвертичного возраста равнинного класса ландшафтов, поверхность которых представляет собой слаборасчлененные полого-волнистые равнины. В настоящее время эта территория в значительной мере освоена под сельхозугодия. 
В пределах описываемых территорий развиты лугово-бурые почвы как со слабо-, так и с резкодифференцированным профилем. К первым относятся лугово-бурые типичные, ко вторым - лугово-бурые отбеленные и лугово-бурые глеево-отбеленные почвы.

Лугово-бурые типичные почвы имеют ограниченное распространение. Они описаны пока только в бассейне р. Раздольная в пределах Октябрьского района. Профиль их слабо расчленен на генетические горизонты. Гумусовый горизонт, достигающий мощности 30-40 см и даже более, имеет серый цвет, комковатую структуру. Он постепенно сменяется иллювиальным горизонтом (50-90 см) буровато-серого или темно-серого цвета со слабым сизоватым оттенком и глянцевым блеском, комковато-призматической структуры. Этот горизонт постепенно переходит в породу - сизо-бурую глину. Окультуренные разновидности почв имеют пахотный слой мощностью 25-30 см.

Лугово-бурые отбеленные почвы развиты в основном в пределах Уссури- Ханкайской равнины под остепненными разнотравно-злаковыми группировками в комплексе с кустарниковыми зарослями. Гумусовый горизонт этих почв имеет мощность 10-20 см, серый или темно-серый цвет, комковато-порошковатую структуру. Его резко сменяет отбеленный горизонт, мощностью 15-20 см, пепельного или серовато-пепельного цвета, слоистый (листоватый), слабопористый или уплотненный с большим количеством конкреций. Ниже расположен переходный горизонт мощностью 8-10 см с обильной белесой присыпкой. Последний сменяется темным иллювиальным горизонтом (60-80 см), для которого характерна глянцевая сизо-бурая или грязно-серая окраска, призматически слоистая, иногда зернистая структура. По трещинам отдельности отмечается белесая мучнистая присыпка. В средней и нижней частях почвенного профиля довольно часто встречаются темные гумусированные прослойки и линзы. Окультуренные разновидности этих почв имеют пахотный слой мощностью 25-30 см и более.

Лугово-бурые глеево-отбеленные почвы распространены на севере Уссури-Ханкайской равнины. Формируются они в урочищах осоково-вейниковых лугов и осиново-березовых редколесий с участием ивы и дуба. В целинном состоянии почвы имеют гумусовый горизонт серого цвета, комковато-порошистый или комковатый, мощностью 10-15 см. Ниже идет пестрый палево-сизый с охристыми пятнами слабо осветленный горизонт который на глубине 40-50 см постепенно переходит в сизо-се- рый иллювиальный горизонт мощностью 50-80 см. Особенность морфологии этих почв - наличие глубоких (до 30-40 см) затеков гумуса и морозобойных трещин, образование которых связано с быстрым и глубоким промерзанием в условиях переувлажнения.

\section{2 Растительность}

Растительность Приморского края разделяется на лесную, кустарниковую, нелесные типы (луга, болота) и степную. При ландшафтных исследованиях и обобщениях использованы литературные материалы и геоботанические материалы геолого-съемочных работ масштаба 1:50000 фондов Примгеолкома.

Лесная растительность. Большое разнообразие и мозаичность природных условий в Приморском крае причина того, что в каждой из нескольких десятков лесных формаций, представленных в крае, формируется большое число типов леса. Изученность типологического состава лесных формаций Приморья пока весьма неравномерна. Поэтому, а также в связи с неодинаковым площадным распространением формаций, их характеристика дается ниже с различной детальностью: от общей характеристики формаций в целом (например, каменноберезники) до групп типов леса (ельники, кедровники и др.). Дифференцировать характеристику до типов леса для наших задач нецелесообразно, так как в группь типов объединяются типы леса, сходные по своим основным свойствам и характеристикам.

На территории Приморья получили развитие группы типов лесов: подгольцовые заросли кедрового стланика, каменноберезовые пихтово-еловые, лиственничные, широколиственно-кедровые (кедровники), широколиственно-чернопихтовые, долинные лиственичные, дубовые леса, формирующие определенные группы лесных урочищ (рис. 9).

Подгольцовые заросли кедрового стланика. Заросли кедрового стланика расположены в верхнем поясе гор, где стланик вместе с различными кустарниками (золотистым рододендроном, вейгелой) формирует группировки подгольцевой растительности. На верхнем пределе распространения, по границе с горными тундрами, формируются низкорослые, изреженные, расположенные куртинами заросли стланика, чередующиеся с горно-тундровыми группировками. С понижением абсолютной высоты сомкнутость зарослей увеличивается, часто до 1,0, и они становятся практически непроходимыми. Размеры отдельных экземпляров стла- 


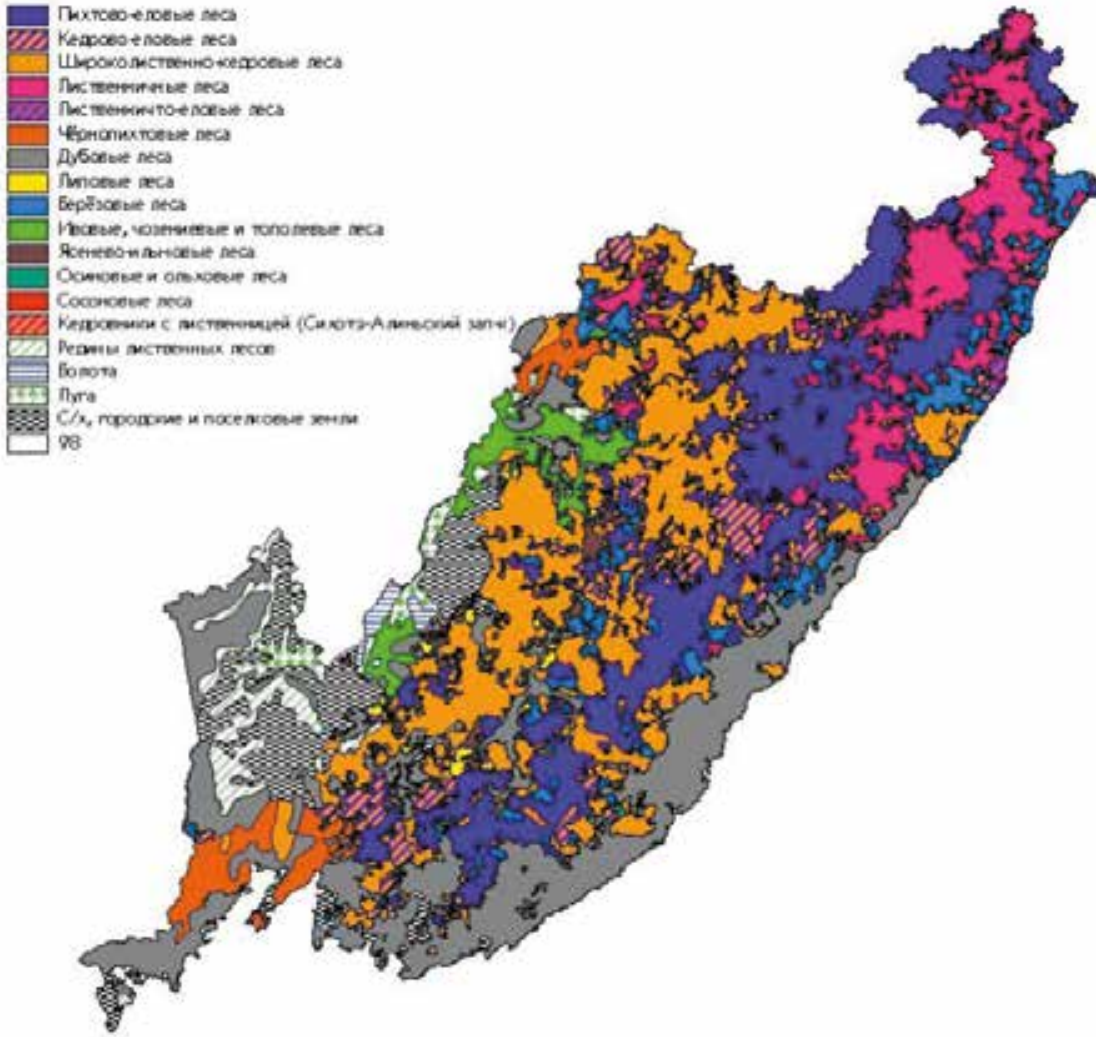

Puc. 9. Схематическая карта растительности Приморского края [119]

ника увеличиваются до 3-4 м высоту и до 10-20 см в диаметре у основания ствола.

Каменноберезовые леса встречаются отдельными участками и сравнительно небольшими массивами на наиболее высоких горных вершинах и хребтах. Самостоятельно или совместно с елью аянской и пихтой белокорой, а иногда с лиственницей (в северной части края) каменноберезники формируют опушку леса. На самом юге Приморья, на п-ове Муравьев-Амурский и на островах зал. Петра Великого, небольшие рощи каменной березы встречаются на открытых морским ветрам склонах возвышенностей. Каменноберезники занимают верхние, обычно крутые части склонов гор с маломощным чехлом грубообломочных рыхлых накоплений и слабо развитыми каменистыми почвами.
Пихтово-еловые леса. Пихтово-еловыми в Приморье принято называть леса, образованные елью аянской и пихтой белокорой. Они формируют ярковыраженную высотную полосу лесной растительности, нижняя граница которой в южной части Сихотэ-Алиня проходит на высоте 600-750 м, а к северу постепенно снижается до 500-400 м. Верхняя граница распространения пихтово-еловых лесов часто являются верхней границей леса, которую они формируют совместно с каменноберезниками, а на севере края и с лиственичниками. По положению в рельефе и по сумме других лесорастительных факторов пихтово-еловые леса Приморья делятся на подгольцовые, горных плато, водоразделов и склонов, горных долин и пологих шлейфов склонов.

Подгольцовые (высокогорные) пихтово-еловые леса встречаются только в верхнем поясе, на наиболее высоких хребтах и вершинах они произрастают на склонах различной крутизны и экспозиции со слаборазвитыми, маломощными каменистыми почвами. В древостоях почти всегда участвует береза каменная, а в северной половине края - лиственница.

Пихтово-еловые леса горных плато, водоразделов и склонов распространены сплошными массивами на водоразделах, базальтовых плато и склонах горных хребтов. Эти леса разделяются на три группы типов: зеленомошные, папортниковые и кустарниковые. Зеленомощные пихтово-еловые леса распространены преимущественно в северной части края. На юге они встречаются реже и на меньших площадях. Примесь сопутствующих пород (березы, лиственницы, кедра, липы) незначительна или отсутствует. Подлесок очень редкий или его нет. Травянистый покров редкий; всюду развит покров из зеленых мхов. Папоротниковые пихтово-еловые леса более распространены в южной и средней частях Приморья. Кустарниковые пихтово-еловые леса занимают значительные площади только в южном Сихотэ-Алине. На севере края встречаются редко и на небольших участках. Сопутствующие породы в этих лесах составляют 30-40\% запаса древостоя. В их число, кроме кедра и березы, всегда входят широколиственные породы.

Пихтово-еловые леса горных долин и пологих шлейфов склонов. В составе лесов чаще других встречаются представители двух групп типов леса: травянисто-моховые и кустарниковые. В травянисто-моховых пихтово-еловых лесах в древостоях преобладают ель аянская и пихта белокорая, встречается небольшая примесь ясеня, берез (ребристой и плосколистной). На севере края - лиственницы. Подлесок развит плохо, беден по составу. На юге 
в нем участвуют клен желтый, рябинолистники, жимолости (Максимовича и съедобная), на севере - ольха пушистая, багульники, изредка кедровый стланик. Группа высокотравно-кустарниковых пихтово-еловых лесов обычно представляет собой переходное звено от темнохвойных к хвойно-широколиственным лесам.

Лиственничные леса в северной части формируются лиственницей даурской, в средней и южной - Ольгинской, Любарского и близкими к ним видами. В подгольцовой полосе участки с преобладанием лиственницы имеются только в северной половине края, на небольших площадях в виде «вкраплений» среди других, главным образом темнохвойных, лесов. Наиболее часто встречаются лиственничники с подлеском из кедрового стланика с лишайниковым или моховым покровом с участием вересковых кустарничков. В среднем и нижнем поясах гор северных и отчасти средних районов края (главным образом на восточном макросклоне Сихотэ-Алиня) леса с преобладанием, а иногда и с абсолютным господством лиственницы, занимают довольно значительные площади (более $30 \%$ всех лиственничников края). Подавляющее большинство их возникло после пожаров и рубок на месте пихтово-еловых, а в отдельных случаях и широколиственно-хвойных лесов. В древостоях обычны березы, осина, ели аянская, реже - корейская, пихта белокорая, иногда кедр и широколиственные породы

В связи с тем что большинство горных лиственничных лесов относится к группе вторичных, облик их довольно разнообразен и неустойчив. На крутых сухих склонах чаще всего встречаются чистые или почти чистые лиственничники с подлеском из рододендрона, можжевельника и других относительно засухоустойчивых и светолюбивых кустарников. На наиболее сухих склонах южных экспозиций изредка произрастают лишайниковые лиственничники. На пологих и средней крутизны склонах различной экспозиции наиболее широко распространены разнотравно-папоротниковые и кустаниково-зеленомошные лиственничники. Лиственничники, возникшие на месте переувлажненных типов темнохвойных лесов, обычно растут лучше, чем существовавшие до них ельники. В большинстве горных лиственничников обычно имеется второй ярус и подрост темнохвойных пород.

Широколиственно-кедровые леса (кедровники) занимают средние и нижние части горных склонов от нижней границы пихтово-еловых лесов до дренированных речных террас. На равнинах, горных плато и в значительных по площади межгорных котловинах кедровники редки или их нет совсем. В южном Приморье они поднимаются в горы в среднем до 500-700 м, в северном - до 300-400 м.

Все разнообразие типов кедровых лесов объединяется в два крупных комплекса: горный и долинный. Горные кедровники занимают большую часть площади кедровых лесов Приморья и растут на склонах различной экспозиции. Они наиболее типологически разнообразны и отличаются большими колебаниями производительности и состава древостоев. В них сосредоточены основные запасы древесины кедра и ценных сопутствующих пород.

Долинные кедровники занимают относительно небольшие площади по речным террасам с мощными, сильно увлажненными почвами аллювиального происхождения. При вырубке кедра они сменяются смешанными широколиственными лесами, в которых кедр восстанавливается с трудом.

Широколиственно-чернопихтовые леса распространены только на юге Приморского края в бассейнах рек, впадающих в зал. Петра Великого. Пихта цельнолистная (или черная) - главный образователь широколиственно-чернопихтовых лесов. В состав этих лесов входит ряд лиственных пород (береза Шмидта, орех маньчжурский, диморфант, бархат амурский, ясень маньчжурский и др.). В флористическом отношении чернопихтарники - самая богатая лесная формация. Подобно лесам с преобладанием кедра корейского, они относятся к сложным многовидовым лесам. Чистых чернопихтовых древостоев без участия других пород в Приморье нет. Обычно в состав даже спелых и перестойных чернопихтовых насаждений входят многочисленные лиственные породы, доля участия которых в первом ярусе доходит до 2-3, в третьем даже до 7-9 единиц.

Долинные лиственные леса эрозионно-аккумулятивного равнинного и долинно-речного рода ландшафтов Приморья представлены ивняками, чозенниками, тополевниками, ильмовниками и ясенниками.

В северной части края (бассейны Бикина, Самарги, Единки) средние уровни пойменных террас заняты ивняками и чозенниками, к высоким уровням приурочены чозениево-тополевые леса, а на участках перехода к склону - тополево-широколиственные и ясенево-ильмовые леса (обычно с участием ореха маньчжурского и бархата). С высоты 350-380 м широколиственные формации (ильмовики с ясенем) из долинных лесов выпадают и последние 
представлены только чозенниками и тополевниками. Леса с преобладанием ясеня маньчжурского в северной части Приморья крайне редки.

В средней части края (бассейны Большой Уссурки, Заболоченной, Таежной) пойменные леса в основном сформированы ивняками и тополевниками. Чозенники, широко распространенные на севере Приморья, встречаются реже и небольшими участками. В зоне перехода от долин к склонам до высоты 450-500 м значительные площади заняты широколиственными лесами с преобладанием ильма долинного. Ясенники наиболее характерны для бассейна р. Малиновка.

Дубовые леса довольно широко распространены в Приморье, представлены дубом монгольским. Другие дубовые леса, образованные дубом зубчатым, встречаются довольно редко, только на самом юге края (западное и юго-западное побережья зал. Петра Великого), где, несмотря на пожары, еще сохранились дубовокустарниково-разнотравные редколесья. Большая часть современных дубняков в зоне смешанных лесов в условиях низкогорного терригенного и расчленненносреднегорного полисубстратного родов ландшафтов возникла в результате пожаров и вырубок на месте кедрово-чернопихтово- и елово-широколиственных лесов.

По особенностям условий среды произрастания, сходству состава древостоя на стадии спелости и видового состава подлеска и покрова выделяются четыре основные группы типов дубняков рододендровые, леспедециевые, лещиновые, папортниково - кустарниковые.

Рододендровые (сухие) дубняки растут повсеместно, но небольшими площадями. Приурочены они к скалистым вершинам гор и прилегающим к ним очень крутым склонам (круче $30^{\circ}$ ) преимущественно южных экспозиций. На севере края в составе дубняков обычна лиственница, а на юге - ясень клюволистный, сосна могильная, изредка - можжевельник твердый.

Леспедецевые (периодически сухие) дубняки - наиболее распространенная группа типов дубняков. Приурочены к крутым частям склонов преимущественно южных экспозиций. В северной и средней частях края в этих дубняках обычны лиственница, ель корейская, кедр; на юге - береза Шмидта, ясень клюволистный, пихта цельнолистная.

Лещиновые (свежие) дубняки так же широко распространены в Приморье, как и предыдущая группа типов. Растут на пологих и среднекрутых склонах преимущественно южных экспозиций.
Кроме дуба, в формировании насаждений постоянно участвуют кедр, ель корейская, береза даурская, липы амурская и Такета, а на юге Приморья - пихта цельнолистная, клен ложнозибольдов, ясень клюволистный, вишня Максимовича и сахалинская.

Папоротниково-разнокустарниковые (влажсные) дубняки в Приморье повсеместны, но занимают меньшие площади, чем каждая из трех предыдущих групп. Приурочены к нижним и средним частям склонов всех экспозиций и к участкам высоких речных террас. На севере края, кроме дуба, присутствуют ели аянская и корейская, кедр, ясень маньчжурский, бархат, осина Давида, береза маньчжурская, реже - лиственница; на юге, кроме ясеня и бархата обычны пихта цельнолистная, диморфант, мелкоплодник, граб.

Кустарниковая растительность. Значительные пространства в зоне хвойно-широколиственных лесов заняты зарослями кустарников. Большая их часть возникла в результате последовательной деградации древесного полога различных лесов под влиянием лесных пожаров и вырубок [120]. По составу господствующих видов они довольно разнообразны. Наибольшим распространением пользуются заросли лещины разнолистной и леспедецы двуцветной, произрастающие на хорошо дренированных почвах увалов и горных склонов. Вместе с разреженными лещинными и леспедециевыми дубняками, на месте которых они возникли, эти заросли придают характерный облик ландшафтам густонаселенных районов Приморского края. В зарослях этих кустарников всегда в большом количестве растут многочисленные травянистые растения. Особенно обильно представлены семейства зонтичных, губоцветных, колокольчиковых, сложноцветных (полыни, астры, осоты, сосюрей и др.). Заросли представляют большую ценность как медоносные угодья и источник вкусных орехов лещины.

Нелесные типы растительности. Нелесные типы растительности - луга, болота, степи - распространены на Уссури-Ханкайской равнине, по широким долинам рек, берегам озер на приморских низменностях. В крае распространены вейниковые и разнотравно-вейниково-осоковые луга, травяные болота, разнотравно-злаковые умеренно увлажненные и суходольные луга и группировки степной растительности $[115,120]$.

Мокрые и влажные вейниковые луга. В зависимости от господствуюших в травостое растений выделяется несколько их типов.

Луга из вейника Лангсдорфа занимают огромные площади на Приханкайской низменности и в приустьевых частях долин 
равнинных рек. Значительные участки, занятые такими лугами, отмечаются в долинах средних и даже верхних течений крупных рек. Травостой до 100-120 см высотой, общее покрытие и задернованность почвы до $100 \%$. Среди сплошных зарослей вейника Лангсдорфа (до $95 \%$ зеленой массы, на таких лугах растут кровохлебка мелкоцветковая, зюзник, дербенник, валериана).

Луга из вейника узколистного занимают промежуточное положение между низинными травяными болотами и лугами из вейника Лангсдорфа. Травостой до 100-120 см высоты, густой. Проективное покрытие и задернованность почвы до $100 \%$. Абсолютно господствует вейник узколистный, реже отмечаются горцы (Тунберга, Маака), осоки (Лакса, Мейера, пушистоплодная), сабельник, вахта, ирис, тростник, вех, хвощ топяной и др.

Вейниково-осоковые луга наиболее типичны, а иногда и господствуют в широких долинах рек. На Приханкайской низменности встречаются фрагментарно на ограниченных участках вблизи замкнутых водоемов. Вся поверхность лугов покрыта кочками, пространство между которыми обычно бывает залито водой. Травостой до 100-180 см. Задернованность и проективное покрытие неравномерны: на кочках $100 \%$, общие до 70-80\%. В составе травостоя многочисленны (до 50-70 видов) влаго- и светолюбивые травы. Господствуют в первом подъярусе вейники (узколистный, Лангсдорфа) и крупнокочковатые осоки. В меньшем количестве участвуют лабазник клопогон и простой, соссюрея амурская и др. Во втором подъярусе представлены: осоки, лобелия, горечавка, борец; основными видами третьего подъяруса являются папоротник болотный, шлемник, калужница и многие другие. Между кочками непосредственно в воде растут кизляк, тростник, вех, ручейник. Нередки кустарники: таволога иволистная, береза овальнолистная, ива.

Вейниково-разнотравные луга развиты на дерново-аллювиальных почвах долин и террас оз. Ханка. Они сменяют в профиле описанные выше мокрые вейниковые луга. Поверхность обычно слабонаклонная в сторону ближайшей реки или балки. Состав травостоя варьирует в зависимости от степени увлажнения, интенсивности выпаса, сенокошения, частоты палов, топографии местности и окружающей растительности. Наиболее типичными представителями вейниково-разнотравных лугов являются следующие.

Сырые вейниковые луга с небольшой примесью разнотравья, распространенные на восточной части Приханкайской низмен- ности и на прирусловых повышениях долин равнинных рек В травостое преобладает вейник Лангсдорфа (до $95 \%$ зеленой массы). В разнотравье представлены кровохлебка, зюзник, валерьяна и др.

Сырые вейниковые луга с большой примесью бобовых трав, занимающие обычно небольшие участки среди других ассоциаций вейниковых лугов у подножий небольших возвышенностей и увалов, покрытых разнотравно-луговой и лугово-степной растительностью. Характерной особенностью этих лугов является большая примесь в травостое дикорастущих вик (иногда до $20 \%$ зеленой массы). Кроме вик в разнотравье представлены полынь побегоносная, астры и ряд других.

Вейниково-осоково-разнотравные луга покрывают довольно большие площади во всех районах края. Типичны для озерных и речных террас. Вейник обычно не более 60-70 см в высоту, не выколашивается и не является преобладающим в травостое. Большую роль играют осоки и разнотравье (более 50 видов). Господства какого-либо одного вида не наблюдается. Типичны уже упомянутые выше луговые травы. Нередко бывает много кустарников, особенно тавологи иволистной и мелкой ивы.

Вейниково-разнотравно-осоковые луга характеризуются преобладанием в травостое осок средней величины, не образующих крупных кочек. Местами группируются пушицы и болотница. Разнотравье, играющее подчиненную роль, представлено кокушником, дербенником, девисилами, кабенарией и некоторыми другими.

Травяные болота играют наиболее заметную роль в растительном покрове восточной части Приханкайской низменности, а также повсеместно встречаются по долинам рек, где чередуются с мокрыми и влажными лугами. Болота занимают наиболее пониженные участки, лишенные стока, с водонепроницаемыми подстилающими глинами. Характерной особенностью травяных болот Приморского края является обычное господство одногодвух видов болотных трав. Остальные растения распространены диффузно или небольшими группами.

Наиболее типичными представителями травяных болот являются следующие.

Вейниково-осоковые болота с господством вейника болотного и осоки пушистоплодной. Образуют крупные массивы в восточной части Приханкайской низменности (район сел Духовское, Сташевка). Травостой до 50-60 см, покрытие 90\%, задерненность 
98-100\%. Кроме вейника и осоки встречаются актиностема, анейлема, стрелолист и др.

Осоковые болота с господством осок пушистоплодной и Мейера распространены главным образом там же, но обычны и в долинах равнинных рек. В отличие от только что упомянутых болот, здесь много кочек из осоки Мейера. Травостой 50-60 см, покрытие и задернованность до $90 \%$. Среди сплошных зарослей осок спорадически отмечаются вейники (болотный, узколистный), тростник обыкновенный, вахта, калужница, зюзники и др.

Пушицево-осоковые болота развиваются в долинах, где возникают наименее дренированные участки. Травостой 50-60 см высотой, покрытие почвы до 90\%, задернованность 50-60\%. Кроме пушицы и осок пушистоплодной и Мейера, отмечаются вейник болотный, кровохлебка мелкоцветная, дудник Максимовича.

Крупнотравные болота типичны для зарастающих водоемов. Сравнительно узкой полосой они окаймляют берега равнинных рек, старичных озер и лагун. Растительность местами представлена одним тростником, достигающим двухметровой высоты. Вдоль берегов водоемов обычны густые заросли дикого риса (цицания), рогоза, аира, осоки, стрелолиста, бутомуса, каллы и др. На свободной водной поверхности обычны колонии ряски, водяного ореха сальвинии. Крупнотравные болота - это первый этап зарастания водоемов. В дальнейшем крупнотравные болота сменяются осоковыми, осоково-вейниковыми, а те в свою очередь мокрыми вейниковыми лугами.

Суходольные луга занимают значительную часть безлесных пространств края. В настоящее время они продолжают формироваться на местах лесных пожарищ [285]. По первичным природным ассоциациям травостоя и в зависимости от доминирующего злака среди них выделяются разнотравно-полевицевые, разнотравно-вейниковые (с вейником наземным), разнотравноарундинелловые, разнотравно-арундинеллово-серобородниковые и мискантусовые луга. Флористический состав суходольных лугов исключительно разнообразный. Кроме доминантных, насчитывается до 80 видов трав. Высота травостоя от 50-60 до 100 см и более, проективное покрытие почвы 80-90\%, задернованность $60-70 \%$.

Степная растительность. Степная растительность сохранилась совсем незначительными по площади участками на высоких речных и озерных террасах, шлейфах пологих склонов и конусах выноса в пределах Уссури-Ханкайской равнины, на юге Хасан- ского района и на морском побережье. По видовому составу травянистого яруса в степной растительности выделяются две группы ассоциаций: разнотравно-арундинелло-келериевая и злаково-разнотравно-пижмовая.

Разнотравно-арундинелло-келериевые ассоциации степной растительности сохранились в бассейнах рек Мельгуновка, Комиссаровка, Турга и в ряде других пунктов. Из злаков кроме келерии и арундинеллы изредка встречаются полевица Триниуса, зубровка, овсец, мятлики. Разнотравье насчитывает несколько десятков видов ксерофитных растений. Метелки злаков в высоту достигают 40-50 см, но главная масса травы не выше 25-30 см. Проективное покрытие почвы 70-80\%, задернованность до $40 \%$. Структура травостоя типичная для степей: основные виды (келерия и арундинелла) образуют дернины, а пространство между ними занято мелкими осоками и разнотравьем.

Злаково-разнотравно-пижмовые ассоциации степной растительности с участием ярко выраженного ксерофита - пижмы сибирской - встречаются небольшими участками в долинах рек Комиссаровка, Мельгуновка, Раздольная на высоких террасах со супесчаными или суглинистыми хорошо дренированными почвами. Злаки здесь распространены диффузно. Разнотравье (до 70 видов) явно преобладает. Общее покрытие почвы до $70 \%$, а задернованность не превышает 30-40\%.

В заключение лекции отметим, что рассмотренные выше компоненты - это составные части реальных ландшафтов, обладающие определенными региональными и локальными особенностями, проявляющимися в экологически значимых свойствах геосистем. Многие компонентные объекты, прежде всего формы рельефа, растительные ассоциации, элементарные комплексы являются природными формированиями, хорошо выраженными комплексами и на правах фаций, простых и сложных урочищ, групп урочищ входят в систему ландшафтов, часто дают им названия: мелкосопочные ландшафты, болотные и пойменные, луговые и степные, разнообразные лесные. Они обладают определенными ландшафтно-компонентными качествами (геологическим, рельефным, климатическим, почвенным), под которыми понимается их способность за счет собственного природного потенциала в течение длительного времени сохранять и поддерживать динамику развития, вещественный потенциал территории и её устойчивый экологический уровень [257]. Их изучение необходимо для выявления и анализа стадий деградации природной среды, опре- 


\section{Контрольные вопросы}

1. Привелите характеристику особенностей горно-таежных почв.

2. Охарактеризуйте особенности горно-таежных бурых иллювиально-гумусовых почв.

3. Охарактеризуйте особенности горно-таежных охристо-бурых почв.

4. Приведите характеристику особенностей горно-лесных бурых почв.

5. Охарактеризуйте особенности почв под широколиственными и хвойно-широколиственными лесами.

6. Охарактеризуйте особенности почв разнотравно-злаковых остепненных лугов и редколесий по суходольным лугам.

7. Охарактеризуйте группу лесов подгольцовых зарослей кедрового стланика.

8. Охарактеризуйте каменноберезовые леса.

9. Охарактеризуйте пихтово-еловые леса

10. Охарактеризуйте лиственичные леса.

11. Охарактеризуйте широколиственно-кедровые леса (кедровники).

12. Охарактеризуйте широколиственно-чернопихтовые леса.

13. Охарактеризуйте долинные лиственничные леса.

14. Охарактеризуйте дубовые леса.

15. Охарактеризуйте кустарниковую раститеость.

16. Охарактеризуйте нелесные типы растительности.

17. Охарактеризуйте болотную, степную растительность.

\section{Лекция 8}

\section{ОРГАНИЗАЦИЯ И ИЕРАРХИЧЕСКАЯ СТРУКТУРА ЛАНДШАФТОВ}

\section{1 Приморье в системе ландшафтов России (принципы классификации, картографирование, новые подходы)}

Обращаясь к вопросу классификации ландшафтов территории России и месту в нем Приморья, следует напомнить, что высшим ландшафтным подразделением планеты является ландшафтная сфера, часть географической оболочки Земли. По Ф.Н. Милькову, в ней обособляется пять отделов ландшафтов: наземные, земноводные, водные, ледовые, донные. Они подразделяются на классы, прежде всего горные и равнинные. А.Г. Исаченко, говоря о необходимости всеобъемлющей классификации ландшафтов страны, на первое место поставил тип ландшафта с следующей ступенью подтип ландшафта (вместе - это зональная группа) Классификационным критерием следующей ступени служит гипсометрический фактор: в каждом типе и подтипе выделяются классы ландшафтов.

Систематика ландшафтов Приморья выполняется в этом обзоре по А.Г. Исаченко и И.С. Гудилину: под их редакцией созданы опубликованные ландшафтные карты СССР [76, 77, 117, 118] с детальными легендами. Сразу оговоримся, что в Приморье классических платформенных равнин нет, и имеющиеся равнинные участки это части горных подвижных поясов. Оба автора используют достаточно сложные матричные легенды: по вертикали (сверху - вниз) размещены зональные подразделения, по горизонтали (слева -направо) классификационные единицы, отражающие «азональные» факторы - геологическое строение, литологию, высотную ярусность.

В схеме таксономических единиц И. С. Гудилина высшей единицей назван «Раздел ландшафтов» - это наземные ландшафты, 
которые подразделяются на два отдела: равнинно-платформенный (их в Приморье нет), и горных подвижных поясов. Далее следует подразделение их на группы ландшафтов, с одним названием «суббореальные континентальные». В современных словарях разделы и группы ландшафтов как классификационные единицы отсутствуют [155]. У А.Г. Исаченко в его системе ландшафтов СССР высшей классификационной единицей являются зональные группы или серии, учитывающие имеющее глобальное значение, климатическое в своей основе, зонально-поясное подразделение суши (в Приморье - суббореальный (южная часть) и бореальный пояса (северная часть, на широте Хабаровска), с последующим разделением на зоны. При этом учитывается фактор секторности (удаленности от океанов), с выделением секторных рядов. Приморье входит в Притихоокеанский (Дальневосточнный) сектор. По сочетанию зональных и секторных критериев выделяются типы и подтипы ландшафтов.

У И.С. Гудилина эта совокупность единиц называется «поясно-секторные группы». В сочетании с выделенными классами (их 4, в т.ч. 2 для Приморья - равнины межгорные, горы) и зональных групп ландшафтов автором показана приуроченность к ним родов ландшафтов: в бореально-приокеаническом и суббореальном (тихоокеанском) на равнинах межгорных и предгорных, в горах с выделением региональных вариантов, среди которых явно должен быть, но не назван тот, что соответствует Приморью.

Следующая ступень у А.Г. Исаченко - классы (подклассы) ландшафтов, учитывающая главные высотные ландшафтные уровни - равнины и горы. В дальнейшем разделение на подклассы (равнины низкие, высокие; низкогорья, среднегорья, высокогорья) отражается ярусность ландшафтов, трансформирующая зонально-секторные черты в связи с ростом высоты и представляющая в виде высотной поясности. Важное ландшафтообразующее значение твердого фундамента с присущим ему рельефом и составом подстилающих пород показывается одной из главных классификационных единиц, которая называется род ландшафта. Род ландшафта - один из главных критериев, отражающих и секторность, и ярусность, и генетическую специфику, но А. Г. Исаченко это словосочетание не употребляет.

По схеме поясно-секторных групп, типов и подтипов ландшафтов И.С. Гудилина Приморье попадает в группу СБпр - Суббореальные приокеанические (Тихоокеанские) с широтно-зональным типом - широколиственно-лесные (80) и высотно-зональным типом - горные широколиственные леса (81). Но основную территорию (Сихотэ-Алинь) занимает бореально-приокеаническая секторная группа (Бпр) с горными таежными лесами (43), граничащая на С3 (в сторону Амура) с подтаежными (мелколиственнохвойными) лесами (42).

Классы: равнины межгорные, предгорные; горы.

Группа ландшафтов: бореально-приокеаническая (тихоокеанская).

Роды: 682a; 686б; 688a; 691a; 6926; 693a; 695a; 698; 699ж, о (аллювиально-пролювиальные, денудационные; денудационно-эрозионные; денудационные с разделением на низкогорья, среднегорья, высокогорья; денудационно-эрозионные с теми же градациями.

Указанные подразделения (роды) входят в высотно-зональные типы и подтипы: таежные низкогорья, таежные и редколесно-таежные среднегорья, лесные низкогорья с широколиственными лесами. Их аналогами являются роды 700в, г; 704ж, з, е; 705д; 707в д, ж, и; 708б, д, е, ж, г (эрозионные, денудационно-эрозионные) тоже входящие в группу ландшафтов бореальные приокеанические и океанические, и относящиеся к тем же высотно-зональным типам и подтипам, что и вышеуказанные (номера на 600).

Роды 923а, б; 924г; 925а, г, д, е, ж; 927a; 928в; 930б, в; 931в; 932a; 933a; 934a; 935a, и, 3, е; 936а, б; попадают в группу ландшафтов суббореальные приокеанические (тихоокеанские) в широтно-зональный тип широколиственно-лесные (923-931), в высотно-зональный тип - горные леса (широколиственные), с подтипом лесные низкогорья (932-936). Эти роды по отложениям - морские, аллювиальные, озерно-аллювиальные, смешанного происхождения, болотные, денудационные, денудационно-эрозионные. Роды 934-936 - разделяются еще и по высотным параметрам на низко-средне-высокогорные. Как реально выглядит описание по всем категориям, с детальной характеристикой видов ландшафтов, можно судить по данным, опубликованным на стр. 301-302 монографии под ред. И. С. Гудилина. Это юго-восточное обрамление Приханкайской равнины, бассейн р. Илистой.

Горы.

Горные леса (широколиственные).

Лесные низкогорья с широколиственными лесами.

Денудационно-глыбовые.

ХІІІ. Даурско-Дальневосточные. 934а. Холмогорья останцовогрядовые пологосклонные, сложенные терригенными породами, 
с дубовыми травяно-кустарничковыми лесами и редколесьями. 934б. Холмогорья с участками денудационных увалистых равнин, пологосклонные, сложенные преимущественно интрузивными породами, с сельскохозяйственными землями.

Из приведенного небольшого примера видно, что описания ландшафтов, как такового, у И.С. Гудилина нет, и вся монография, в соответствии с названием, фактически развернутая легенда, А. Г. Исаченко, поскольку его монография и карта предназначены для учебных целей, придерживается другой формы подачи материала: есть указания на причинно-следственные связи взаимодействия компонентов в ландшафтах, оценка важнейших процессов их функционирования (влагооборот, параметры стока и водного баланса, почвообразование и биогенный круговорот веществ, тепло- и влагообеспеченность, сезонная динамика). Например, по Сихотэ-Алиню в описании Дальневосточных подтаежных ландшафтов (23) отмечается развитость предгорий западного склона с пихтово-еловыми лесами низкогорно-подтаежной части указано на трудность вычленения яруса среднегорий и высокогорья, представленного незначительными участками на высотах выше 1500 м. Но явным доминатом северной и центральной части являются низко- и среднегорные темнохвойные леса, смешанные леса, вторичные лиственичники, на переходах к высокогорью есть заросли кедрового стланика, россыпи, лишайниковые пятна на мелкоземе, но горных тундр нет.

Через систему широколиственно-хвойных лесов, типичных только для гор, осуществляется переход к суббореальным гумидным ландшафтам юга Сихотэ-Алиня, расположенных в среднегорных, низкогорно-предгорных местоположениях, горных речных долинах. Крайний юг Сихотэ-Алиня и прилегающие территории, по мнению А.Г. Исаченко, следует выделять в особую подзону, но в основном она простирается за пределами границ страны. Здесь распространены специфические вторично-степные и плавневые ландшафты Приханкайской низменности, цокольные равнины и холмистые равнины с трансформированными лесами. Южная половина Сихотэ-Алиня имеет хорошо выраженный низкогорный пояс широколиственных лесов, выше 500 м идут леса кедровошироколиственные или вторичные производные, березовые. Еще выше, в среднегорном ярусе (800-1300-1500 м) заметна примесь темнохвойных пород (аянская ель и белокорая пихта), наиболее высокие местоположения безлесны и заняты кустарниками, фрагментами мохово-лишайниковых тундр среди каменистых россыпей, которые намного севернее, за границами Приморья образуют настоящий гольцовый пояс, относящийся к высокогорью. Такое выпадение поясов для сравнительно невысоких гор, к тому же расположенных в приокеанической части, является закономерным, связанным с ландшафтной континентально-океанической дихотомией.

Что касается тех фундаментальных различий в ландшафтах, которые отражают их геолого-геоморфологическую специфику, то в классификации А. Г. Исаченко они присутствуют в названиях видов ландшафтов: холмистые предгорья на складчатых мезозойских и кайнозойских терригенных породах (20/40), внутригорные впадины, преимущественно с озерно-аллювиальной аккумуляцией (20/46), складчатые и складчато-глыбовые низкогорья и среднегорья на кайнозойских и мезозойских, частично палеозойских структурах и неоген-четвертичных лавах (79/49, 59/49 и др.). В результате на ландшафтной карте отражаются особенности Сихотэ-Алиня (максимальная высота 2077 м) как мезозойского антиклинория, ограниченного разломами, по которым в кайнозое происходили излияния базальтов. В осевой зоне хребта по западному склону выходили на поверхность сильно дислоцированные палеозойские осадочные и эффузивные породы, крылья сложены мезозойскими песчаниками и конгломератами, алевролитами, аргиллитами и эффузивами [244]. Преобладающие высоты до 800-1000 м, рельеф типично эрозионный, лишь отрепарированные гранитные интрузии образуют более высокие купола, вершины со следами оледенения и горными тундрами (1400-1500 м).

Завершая обзор положения Приморья в системе ландшафтов России, можно сделать несколько выводов. 1. Предлагаемые классификации и подготовленные (опубликованные) ландшафтные карты заложили основы мелкомасштабного ландшафтного картографирования региона. 2. Имеющийся опыт может и должен быть использован при создании ландшафтных карт другого масштабного ряда - среднемасштабных (миллионных и полумиллионных). 3. Новые картографические произведения должны опираться на значительно возросшую естественно-научную базу ландшафтной географии, созданные в последние годы геологические, почвенные, геоморфологические, геоботанические карты. 4. Современные ландшафтные карты должны отражать новые представления, новые подходы к ландшафтам как образованиям намного более сложным, чем это виделось 25-30 лет назад: по пространственно-временной организации они становятся похожими на живые 
образования [153]. Для того, чтобы оставаться в фарватере общего природоведения, ландшафтной географии необходимо сочетать ландшафтно-картографический подход с модернизацией ландшафтной теории, переходить к синергической парадигме, расширению региональных исследований пространственно-временной организации геосистем и их биосферных функций.

В частности, продуктивным может быть развитие феноменологических представлений о Сихотэ-Алинском региональном ландшафтном экотоне как сопряженной парагенетической системе природно-территориальных комплексов трех категорий геоэкотонов - климатической (связанной с муссонной компонентой), орографической (мегантиклинорий) и фиторастительной (суббореальные широколиственные леса). Иерархическое устройство ландшафтного пространства, частично отражаемое в ландшафтных картах, многоуровневые способы интеграции природных компонентов в геосистемы разного таксономического ранга свидетельствуют, как указывает Э.Г. Коломыц [95], о полиморфизме гео (эко) саморегуляции и устойчивости на основе изучения вещественно-энергетического и информационного взаимодействия разносубстратных природных комплексов. В Приморье для этого необходимы серьезные экспериментальные исследования. Поэтому первой задачей, решаемой автором в рамках ландшафтно-географических исследований, стало создание региональной ландшафтной классификации.

\section{2 Классификация ландшафтов Приморья}

«Классификация - универсальная общенаучная процедура, без которой исследование не может быть завершенным. Разработка классификации заставляет теоретически осмыслить все многообразие фактов, относящихся к изучаемым объектам. В классификации находят свое выражение синтез закономерностей развития, строения, функционирования, размещение ландшафтов. Ландшафтная классификация имеет большое организующее значение как основа для научного описания ландшафтов. Велико и практическое значение классификации» [78, с. 231]. Функционально значимой и наглядной производной классификации ландшафтов является ландшафтная карта, составленная на основе анализа и систематизации массового ландшафтного материала. Однако, несмотря на значимость систематики ландшафтов, она еще недостаточно разработана, хотя уже 30 лет назад были, как отмечалось выше, созданы классификации, легенды и мелкомасштабные карты [76]. В Приморском крае среднемасштабное ландшафтное картографирование и разработки классификаций и легенд не проводились, хотя потребность в них на современном этапе развития природопользования усиливается, в частности, как отмечалось выше, для использования их в качестве географических основ экологических исследований.

Нами разработана классификация и легенда ландшафтов Приморского края для карты масштаба 1:500000. За основу взята система типологических рядов регионального уровня А. Г. Исаченко [78] (рис. 10).

Использованы также теоретические положения ландшафтного картографирования Ф.Н. Милькова, В.С. Преображенского, И.С. Гудилина и др. исследователей, в частности, В.С. Тикунова [273].

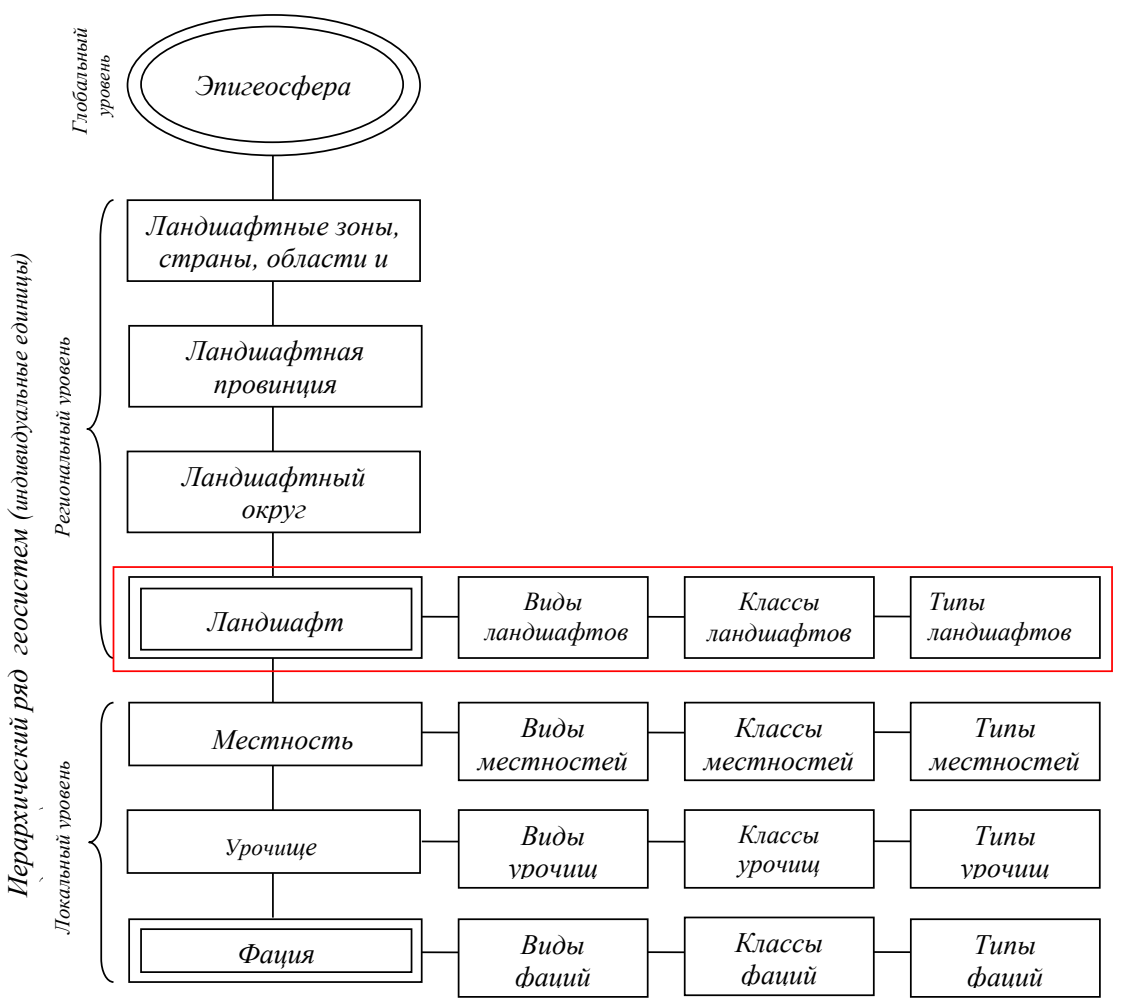

Puc. 10. Типологические ряды геосистем [по А.Г.Исаченко, 78] 
Ландшафт определяется, по А. Г. Исаченко, как «генетически единая геосистема, однородная по зональным и азональным признакам и заключающая в себе специфический набор сопряженных локальных геосистем» [78, с. 111]. При этом ландшафт имеет однородный геологический фундамент, одинаковый климат, ограниченный набор форм рельефа и группировок почв, растительности. Виды ландшафтов по А.Г. Исаченко включают ландшафты, наиболее близкие по своему генезису, структуре и морфологии. Важными признаками ландшафтов одного вида является преобладание однотипного рельефа и фундамента. Класс горных ландшафтов отличается наличием ярусности и высотной поясности [78]. Основной критерий для разграничения типов ландшафтов - важнейшие глобальные различия в соотношениях степени континентальности и режима увлажнения [78]. При практическом использовании отмеченных рекомендаций для региональных условий Приморского края нами введены местные классификационные признаки (типы и транзит обломочного материала, глубина эрозионного вреза, густота горизонтального эрозионного расчленения и др.). Это определяется необходимостью более глубокого учета местных ландшафтных условий.

Информация по компонентам ландшафтов (они приведены в лекциях $4,5,6,7)$, предопределяемым геологическим и геоморфологическим строением, гидроклиматическими характеристиками, почвенно-растительным покровом, проявлением тектонических движений, дала возможность на региональном уровне в Приморском крае выделить иерархические единицы ландшафтов: местность, вид, род, подкласс, класс (табл. 7).

Tuп и класс ландшафтов. В Приморском крае по сочетанию зональных факторов и секторных критериев, ярусности и высотности выделяется дальневосточный бореальный гумидный тип ландшафтов [76]. С дополнением азональных региональных признаков (табл. 7), отражающих особенности дальневосточных природных комплексов и их компонентов, на местном региональном уровне выделяются дальневосточные бореальные гумидные горный и равнинный классы $[225,243,244]$. В свою очередь горный класс включает ландшафты Сихотэ-Алинских и Восточно-Маньчжурских гор.

Дальневосточные бореальные гумидные горный и равнинный классы определяются географическим положением ландшафтов Приморского края в притихоокеанской зоне на стыке Евразии и Тихого океана, континентально-океанической дихотомией,

Единицы ландшафтов Приморского края

и критерии их выделения

\begin{tabular}{|c|c|c|}
\hline $\begin{array}{c}\text { Ландшафтная } \\
\text { единиша }\end{array}$ & Критерий выделения & Примеры \\
\hline Класс & $\begin{array}{l}\text { Географическое единст- } \\
\text { во, сочетание занальных } \\
\text { черт и секторных разли- } \\
\text { чий, ярусность и высот- } \\
\text { ность }\end{array}$ & $\begin{array}{l}\text { Бореальный гумидный } \\
\text { дальневосточный гор- } \\
\text { ный и равнинный }\end{array}$ \\
\hline Подкласс & $\begin{array}{l}\text { Высотность, типы расти- } \\
\text { тельности }\end{array}$ & $\begin{array}{l}\text { Горно-тундровый, } \\
\text { горно- темнохвойный }\end{array}$ \\
\hline Род & $\begin{array}{l}\text { Морфогенетические } \\
\text { типы рельефа, субстрат, } \\
\text { густота горизонтального } \\
\text { эрозионного расчлене- } \\
\text { ния, глубина эрозионно- } \\
\text { го вреза }\end{array}$ & $\begin{array}{l}\text { Низкогорный терри- } \\
\text { генный, мелкосопоч- } \\
\text { ный полисубстратный, } \\
\text { среднегорнорасчле- } \\
\text { ненный полисубстрат- } \\
\text { ный }\end{array}$ \\
\hline Вид & $\begin{array}{l}\text { Растительность и почвы, } \\
\text { рельеф }\end{array}$ & $\begin{array}{l}\text { Низкогорный терри- } \\
\text { генный дубовый на } \\
\text { горно-лесных бурых } \\
\text { почвах }\end{array}$ \\
\hline Местность & $\begin{array}{l}\text { Сопряженные сочетания } \\
\text { однородного фундамен- } \\
\text { та, одинакового климата, } \\
\text { форм рельефа и группи- } \\
\text { ровок почв и раститель- } \\
\text { ности }\end{array}$ & $\begin{array}{l}\text { Массивносредне- } \\
\text { горный широколи- } \\
\text { ственный на гор- } \\
\text { но-таежных почвах } \\
\text { с алевролитовым } \\
\text { вещественным ком- } \\
\text { плексом }\end{array}$ \\
\hline
\end{tabular}

значительной протяженностью в меридиональном направлении, неоднородностью гипсометрической поверхности и тектонических структур фундамента. Все ландшафты Приморского края располагаются в муссонной климатической области умеренного пояса [1]. Климатические особенности определяются в первую очередь муссонным характером циркуляции. Для ландшафтов характерен гумидный климат фреатического типа (гл. 2). В классе горных ландшафтов представлен среднегорно-низкогорный ярус со своеобразной высотной поясностью [243, 244].

Важное место в формировании режима увлажнения, степени континентальности и в целом климатических особенностей лан- 
дшафтов на региональном уровне (гл. 2) занимает пространственная ориентировка долин, отрогов и экспозиции склонов к направлению влагонесущих воздушных потоков на каждом конкретном участке горного типа ландшафтов. Такое влияние в Приморском крае на региональном уровне оказывают Сихотэ-Алинская и Восточно-Маньчжурская горные системы. Главный мегаантиклинорий Сихотэ-Алиня оказывает существенное влияние на развитие атмосферных процессов, как в районе водораздела, так и на прилегающих к нему участках. Долины, ориентированные с запада на восток и с северо-востока на юго-запад, характеризуются повышенным количеством осадков. В закрытых долинах и котловинах центральной части осадков существенно уменьшается по сравнению с горной частью. Наблюдается пятнистость в распределении осадков по территории края. Она является результатом сложного взаимодействия рельефа, абсолютной высоты местности и ее лесистости с циркулирующими над ней влагонесущими потоками $[225,226,232,243,261]$. Формируются характерный для Сихотэ-Алинской и Восточно-Маньчжурской горных территорий режим увлажнения, черты климата, степень континентальности и соответствующий мезоклимат системы ландшафтов.

Подклассы ландшафтов выделяются по высотности в сочетании с типами растительности (таежная, лесная, степная). Сопряженный анализ сочетаний этих компонентов, во взаимосвязи и взаимообусловленности с азональным климатическим фактором, показывает, что в Приморском крае выделяются горно-тундровые, горно-темнохвойные, среднегорно-низкогорные и низкогорные горно-лесные смешанно-широколиственные, лесостепные равнинные и долинно-речные ландшафты (табл. 8, [243, 244]). Кроме того, в общей иерархической системе ландшафтов Приморья нами выделяется реально существующий на стыке с океаном переходный подкласс аквально-территориальных (прибрежно-шельфовых) геосистем. Нами в работе ниже рассматриваются только ландшафты континентальных территорий. Морские геосистемы рассматриваются Б. В. Преображенским [162]

Роды ландшафтов выделяются по морфологическим типам рельефа, субстрату, густоте эрозионного расчленения, глубине эрозионного вреза. Системный анализ компонентов показывает, что по геолого-геоморфологическим параметрам с учетом сопряженных с ними климата, фундамента, почв и растительности на территории Приморского края выделяются роды: гольцовый полисубстратный, массивносреднегорный полисубстратный, расчле-
Подклассы ландшафтов Приморского края (фрагмент)

\begin{tabular}{|c|c|c|}
\hline $\begin{array}{c}\text { Подкласс } \\
\text { ландшафтов }\end{array}$ & Высотный уровень & Растительность \\
\hline Горно-тундровый & Высокогорный & Горно-тундровая \\
\hline $\begin{array}{l}\text { Горно- темно-хвой- } \\
\text { ный }\end{array}$ & $\begin{array}{l}\text { Массивносреднегор- } \\
\text { ный } \\
\text { Расчлененносредне- } \\
\text { горный } \\
\text { Низкогорный }\end{array}$ & $\begin{array}{l}\text { Таежная темнохвой- } \\
\text { ная }\end{array}$ \\
\hline $\begin{array}{l}\text { Горно-лесной сме- } \\
\text { шанно-широколист- } \\
\text { венный }\end{array}$ & $\begin{array}{l}\text { Массивносреднегор- } \\
\text { ный } \\
\text { Расчлененносредне- } \\
\text { горный } \\
\text { Низкогорный } \\
\text { Мелкосопочный }\end{array}$ & $\begin{array}{l}\text { Лесная смешанно- } \\
\text { широколиственная }\end{array}$ \\
\hline $\begin{array}{l}\text { Лесо-степной рав- } \\
\text { нинный и долинно- } \\
\text { речной }\end{array}$ & Равнинный & $\begin{array}{l}\text { Лесостепная, пой- } \\
\text { менно-долинная }\end{array}$ \\
\hline $\begin{array}{l}\text { Прибрежно-шельфо- } \\
\text { вый }\end{array}$ & $\begin{array}{l}\text { Переходный от кон- } \\
\text { тинента к океану }\end{array}$ & $\begin{array}{l}\text { Прибрежно-конти- } \\
\text { нентальная и мелко- } \\
\text { водно-шельфовая }\end{array}$ \\
\hline
\end{tabular}

ненносреднегорный полисубстратный, низкогорный терригенный и вулканогенно-терригенный, мелкосопочный полисубстратный, платобазальтовый, эрозионно-аккумулятивный равнинный и приморско-равнинный.

Кроме того, в результате систематизации родов ландшафтов по классам установлено [225, 226, 232, 243, 251, 257,261], что в горно-тундровом классе наблюдается гольцовый полисубстратный; в горно-темнохвойном - массивно- и расчлененносреднегорный полисубстратные, низкогорный терригенный и вулканогеннотерригенный, платобазальтовый роды; в горно-лесном смешанно-широколиственном - массивно- и расчленено-среднегорный полисубстратные, низкогорный терригенный, мелкосопочный полисубстратный и платобазальтовый роды; в равнинном и долинно-речном лесостепном - эрозионно-аккумулятивный равнинный и долинно-речной роды ландшафтов (табл. 9).

Вид ландшафтов. Важными признаками ландшафтов одного вида являются преобладание однотипного рельефа и состав пород. 
Роды ландшафтов Приморского края

(по подклассам ландшафтов, фрагмент)

\begin{tabular}{|c|c|c|c|}
\hline $\begin{array}{c}\text { Подкласс } \\
\text { ландшафтов }\end{array}$ & $\begin{array}{c}\text { Род } \\
\text { ландшафтов }\end{array}$ & $\begin{array}{c}\text { Геологический } \\
\text { состав }\end{array}$ & $\begin{array}{c}\text { Высотный } \\
\text { пояс }\end{array}$ \\
\hline $\begin{array}{l}\text { Горно-тундро- } \\
\text { вый }\end{array}$ & $\begin{array}{l}\text { Гольцовый поли- } \\
\text { субстратный }\end{array}$ & $\begin{array}{l}\text { Полисубстрат- } \\
\text { ный }\end{array}$ & $\begin{array}{l}\text { Горно-тун- } \\
\text { дровый }\end{array}$ \\
\hline $\begin{array}{l}\text { Горно-темнох- } \\
\text { войный }\end{array}$ & $\begin{array}{l}\text { Массивносредне- } \\
\text { горный полисуб- } \\
\text { стратный } \\
\text { Расчлененносред- } \\
\text { негорный полисуб- } \\
\text { стратный } \\
\text { Низкогорный вул- } \\
\text { каногенно-терри- } \\
\text { генный } \\
\text { Платобазальтовый }\end{array}$ & $\begin{array}{l}\text { Полисубстрат- } \\
\text { ный } \\
\text { Полисубстрат- } \\
\text { ный } \\
\text { Вулканогенно- } \\
\text { терригенный } \\
\text { Платобазальто- } \\
\text { вый }\end{array}$ & $\begin{array}{l}\text { Горно-тем- } \\
\text { нохвойный }\end{array}$ \\
\hline $\begin{array}{l}\text { Горно-лесной } \\
\text { смешанно-ши- } \\
\text { роколиствен- } \\
\text { ный }\end{array}$ & $\begin{array}{l}\text { Массивносредне- } \\
\text { горный полисуб- } \\
\text { стратный } \\
\text { Расчлененносред- } \\
\text { негорный полисуб- } \\
\text { стратный } \\
\text { Низкогорный тер- } \\
\text { ригенный } \\
\text { Платобазальтовый } \\
\text { Мелкосопочный } \\
\text { полисубстратный }\end{array}$ & $\begin{array}{l}\text { Полисубстрат- } \\
\text { ный } \\
\text { Полисубстрат- } \\
\text { ный } \\
\text { Терригенный } \\
\text { Платобазальто- } \\
\text { вый } \\
\text { Полисубстрат- } \\
\text { ный }\end{array}$ & $\begin{array}{l}\text { Горно- } \\
\text { лесной } \\
\text { смешанно- } \\
\text { широколи- } \\
\text { ственный- }\end{array}$ \\
\hline
\end{tabular}

В Приморском крае наряду с рельефом, в качестве индикаторов видового разнообразия рассматриваются растительность и почвы. Систематизация отмеченных ландшафтообразуюших компонентов показала, что существует их высотно-поясная индикаторная специфика. В условиях различных типов рельефа (массивносреднегорного, расчлененносреднегорного, низкогорного и других) формируются, как отмечается в лекции 4,7 , определенные группировки почв и растительности. Поэтому они взяты как критерии выделения видов ландшафтов. Вид ландшафта назван по преобладающей группировке растительности (табл. 10).

Местность (индивидуальный ландшафт) выделяется по сопряженным сочетаниям однородного фундамента, одинакового микроклимата и рельефа, группировок почв и растительности
Виды ландшафтов Приморского края (по подклассам и родам ландшафтов, фрагмент)

\begin{tabular}{|c|c|c|}
\hline $\begin{array}{c}\text { Подкласс } \\
\text { ландшафтов }\end{array}$ & $\begin{array}{c}\text { Род } \\
\text { ландшафтов }\end{array}$ & $\begin{array}{c}\text { Вид } \\
\text { ландшафтов }\end{array}$ \\
\hline $\begin{array}{l}\text { Горно-тун- } \\
\text { дровый }\end{array}$ & $\begin{array}{l}\text { Гольцовый поли- } \\
\text { субстратный }\end{array}$ & $\begin{array}{l}\text { Массивносреднегорный ли- } \\
\text { шайниково-кустарниковый }\end{array}$ \\
\hline $\begin{array}{l}\text { Горно- тем- } \\
\text { нохвойный }\end{array}$ & $\begin{array}{l}\text { Массивносредне- } \\
\text { горный полисуб- } \\
\text { стратный } \\
\text { Расчлененносред- } \\
\text { негорный полисуб- } \\
\text { стратный } \\
\text { Низкогорный вул- } \\
\text { каногенно-терри- } \\
\text { генный } \\
\text { Платобазальтовый }\end{array}$ & $\begin{array}{l}\text { Массивносреднегорный хвой- } \\
\text { нозеленомошный } \\
\text { Расчлененносреднегорный } \\
\text { хвойнозеленомошный } \\
\text { Низкогорный хвойнозелено- } \\
\text { мошный } \\
\text { Платобазальтовый хвойнозеле- } \\
\text { номошный }\end{array}$ \\
\hline $\begin{array}{l}\text { Горно-лес- } \\
\text { ной смешан- } \\
\text { но-широко- } \\
\text { лиственный }\end{array}$ & $\begin{array}{l}\text { Массивносредне- } \\
\text { горный полисуб- } \\
\text { стратный }\end{array}$ & $\begin{array}{l}\text { Массивносреднегорный широ- } \\
\text { колиственно-кедровый } \\
\text { Массивносреднегорный широ- } \\
\text { колиственно-кедрово-еловый } \\
\text { Массивносреднегорный черно- } \\
\text { пихтово-широколиственный } \\
\text { Массивносреднегорный грабо- } \\
\text { во-широколиственный } \\
\text { Массивносреднегорный широ- } \\
\text { колиственный } \\
\text { Массивносреднегорный лист- } \\
\text { веннично-хвойно-смешанный } \\
\text { Массивносреднегорный дубо- } \\
\text { вый } \\
\text { Массивносреднегорный мел- } \\
\text { колиственный по гарям } \\
\text { Массивносреднегорный широ- } \\
\text { колиственно-мелколиственный } \\
\text { Массивносреднегорный мел- } \\
\text { колиственный } \\
\text { Массивносреднегорный пихто- } \\
\text { во-елово-лиственнично-мелко- } \\
\text { лиственный } \\
\text { Массивносреднегорный невоз- } \\
\text { обновившихся молодых гарей }\end{array}$ \\
\hline
\end{tabular}


(структура и описание ландшафтов рассматриваются в лекции 11). Она занимает узловое положение на стыке геосистем региональной и локальной размерностей и является частью более сложных региональных единиц [78, с. 120; 251, 257, 261].

В итоге в Приморском крае в иерархической структуре ландшафтов нами обосновано выделение 2-х классов (горный, равнинный), 4 подклассов (горно-тундровый, горно-темнохвойный, горно-лесной смешанно-широко-лиственный, лесостепной равнинный и территориально сопряженный с ними интразональный гидроморфно-долинный), 12 родов: гольцовый, массивносреднегорный и расчлененносреднегорный полисубстратные, низкогорный терригенный и вулканогенно-терригенный, мелкосопочный полисубстратный и др., 94 видов и 3043 местностей (индивидуальных ландшафтов) [193-271].

Как известно, структура ландшафта отражает организацию ландшафтной сферы и организованность его составных частей в пространстве [19]. Структура ландшафтов Приморского края впервые детально описана и отражена на ландшафтных картах автора [243, 244].

\section{Контрольные вопросы}

1. Какие карты ландшафтов изданы под редакцией А. Г. Исаченко и И.С. Гудилина?

2. Раскройте понятие «Раздел ландшафтов», класс по А. Г. Исаченко.

3. Раскройте понятие роды по И.С. Гудилину.

4. Раскройте понятие классификация ландшафтов.

5. Какие иерархические единицы выделяются в типологических рядах регионального уровня у А.Г. Исаченко?

6. Раскройте понятие ландшафт по А.Г. Исаченко.

7. Раскройте понятие вид ландшафтов по А. Г. Исаченко.

8. Раскройте понятие подкласс ландшафтов по А.Г. Исаченко.

9. Раскройте понятие класс ландшафтов по А.Г. Исаченко.

10. Раскройте понятие тип ландшафтов по А.Г. Исаченко.

11. Раскройте понятие класс, подкласс, род, вид ландшафтов и местности, выделяемые на среднемасштабном уровне в Приморье.

12. Сколько и какие таксоны ландшафтов выделены в иерархической структуре ландшафтов Приморского края?

\section{Лекция 9}

\section{ОРГАНИЗАЦИЯ И ИЕРАРХИЧЕСКАЯ СТРУКТУРА ЛАНДШАФТОВ}

\section{Классы ландшафтов}

Весь ход геологического, геоморфологического и климатического развития территории Приморского края предопределил формирование и разделение территории на генетические географически целостные и внутренне единые территории. Этому послужили общность исторического развития, географического положения горных складчатых Сихотэ-Алинской и ВосточноМаньчжурской территорий и платформенной равнинной Уссури-Ханкайской. Такое физико-географическое структурное разделение территории Приморского края, в свою очередь, предопределило развитие горных и равнинных классов ландшафтов (табл. 11).

Бореальный дальневосточный горный класс ландшафтов на территории Приморья включает Сихотэ-Алинскую и ВосточноМаньчжурскую складчатые горные территории. Они отличаются между собой по физико-географическим характеристикам компо-

Таблииа 11

Классы ландшафтов Приморского края

\begin{tabular}{|l|l|l|}
\hline \multicolumn{1}{|c|}{\begin{tabular}{c} 
Класс \\
\multicolumn{1}{c|}{ ландшафтов }
\end{tabular}} & \multicolumn{1}{|l|}{ Подкласс ландшафтов } & Примеры ландшафтов \\
\hline $\begin{array}{l}\text { Бореальный } \\
\text { дальневосточ- } \\
\text { ный горный }\end{array}$ & $\begin{array}{l}\text { 1. Горно-тундровый } \\
\text { 2. Горно-темнохвойный } \\
\text { 3. Горно-лесной сме- } \\
\text { шанно-широколиствен- } \\
\text { ный }\end{array}$ & $\begin{array}{l}\text { 1. Сихотэ-Алинский } \\
\text { 2. Восточно-Мань- }\end{array}$ \\
\hline $\begin{array}{l}\text { Бореальный } \\
\text { дальневосточ- } \\
\text { ный равнинный }\end{array}$ & $\begin{array}{l}\text { 1. Лесостепной равнин- } \\
\text { ный и долинно-речной }\end{array}$ & 1. Уссури-Ханкайский \\
\hline
\end{tabular}


нентов природы. Выделяется ландшафты Сихотэ-Алинских гор со среднегорными полисубстратными, низкогорными терригенными и другими родами и горно-темнохвойными, горно-лесными смешанно-широколиственными подклассами и видами ландшафтов с хвойными и широколиственными группировками растительности на различных почвах. Структура отличается по ориентировке хребтов, крутизне склонов, густоте речной сети, глубине вреза рек, увлажнению, транзиту рыхлого материала и другим физико-географическим показателям от расположенной на западе Приморья Восточно-Маньчжурской структуры ландшафтов с уже характерными для нее горно-лесным смешанно-широколиственным классом, низкогорным вулканогенно-терригенным родом и видами ландшафтов с широколиственными группировками растительности на бурых лесных и других почвах, развивающимися в условиях западного грабен-горстового борта Амуро-Уссурийской рифтогенной структуры. Отчетливое различие ландшафтов Сихотэ-Алинских и Восточно-Маньчжурских гор, в соответствии с основными положениями ландшафтной географии, позволяет говорить отдельно об их структурах, что нашло свое отражение, в частности, в схемах физико-географического районирования (рис. 1).

Сихотэ-Алинские горы представляют собой систему хребтов различной ориентировки, охватывающих около $70 \%$ всей тер-

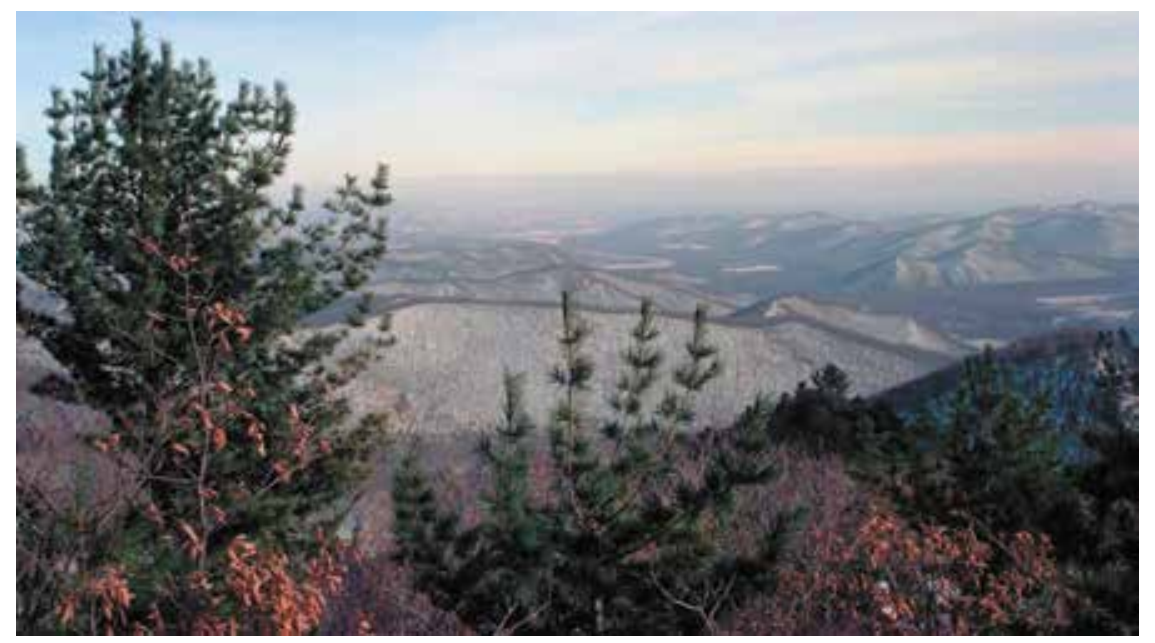

Рис. 11. Горный ландшафт Сихотэ-Алиня (фрагмент). Фото О. Кабалика ритории края (рис. 11). По абсолютной высоте это среднегорье с преобладающими абсолютными высотами 800-1000 м и относительными превышениями 200-400 м. Главный водораздел горной страны простирается в северо-восточном направлении на расстоянии 50-150 км от берега Японского моря. Абсолютные отметки его вершин 900-1746 м, перевалов - 450-700 м. Наивысшие отметки расположены западнее линии главного водораздела (Аник - 1933 м, Облачная - 1855 м).

Горные вершины нигде не достигают снеговой линии. Однако фирновые поля значительной площади формируются в зоне снегового надува ежегодно и сохраняются в стланиках и подгольцовых лесах до второй половины лета. В сочетании с другими факторами сурового климата зоны гольцового полисубстратного рода ландшафтов, снежники (фирновые поля) способствуют формированию специфических микроформ нивального рельефа редких фаций, урочищ.

По линии главного водораздела горная страна Сихотэ-Алинь разделена на япономорский (восточный) и уссури-ханкайский (западный) макросклоны, которые можно рассматривать как отдельные геосистемы, включающие соответствующие бассейны рек, впадающих либо непосредственно в Японское море, либо в оз. Ханка и р. Уссури. Эти две единицы имеют значительные различия по природно-климатическим факторам, поскольку только до линии главного водораздела распространяется циркуляция переувлажненных холодных воздушных масс, поступающих с Охотского и Японского морей в весенний-раннелетний период, и относительно теплых масс - в осенне-зимний.

Япономорский (восточный) макросклон представляет собой систему сравнительно коротких хребтов различного начертания и ориентировки. Степень горизонтальной и вертикальной расчлененности местности здесь наибольшая для всей горной страны Сихотэ-Алинь. Протяженность эрозионных долин до 2 км на 1 кв. км площади и даже более. Относительные превышения водоразделов над днищами близлежащих долин достигают 500-700 м (в зоне расчлененносреднегорного полисубстратного рода ландшафтов возможны и большие перепады). Для Япономорского макросклона свойственно повсеместное распространение обвальных, осыпных и оползневых процессов, эрозионных и абразионных обрывов, денудационных уступов и останцев. От линии главного водораздела в направлении к морскому побережью происходит быстрое общее снижение гипсометрического уровня 
и на расстоянии 15-20 км от моря местность имеет высоты менее 600 м. Характерны очень большие продольные уклоны русел водотоков, развитие горного аллювия, пролювия и накоплений после катастрофических (селевых) потоков.

В северной части расположены два базальтовых плато: Самаргинское и Зевинское (его восточная составляющая), а в южной Артемовское плато. В пределах плато развиты плоские, столообразные поднятия. На них в западинах образуются верховые болота. Большие пространства покрыты лиственничными лесами с торфянисто- и торфяно-глеевыми переувлажненными почвами.

Уссури-Ханкайский (западный) макросклон морфологически подразделяется на Центральный Сихотэ-Алинь и Западный Сихотэ-Алинь (рис. 1).

Центральный Сихотэ-Алинь охватывает часть территории к северо-западу от линии главного водораздела. Его северо-западная (западная) граница проходит по долинам рек, трассирующих зону Центрального структурного шва: Дальняя, Перевальная, Малиновка, Откосная, Уссури, Матвеевка. Горные цепи Центрального Сихотэ-Алиня имеют преимущественное направление CCB, т.е. совпадающее с генеральным направлением складчатых структур и зон разрывов. К этой части горной страны приурочены наиболее возвышенные участки массивносреднегорного полисубстратного рода ландшафтов с абсолютными отметками до 1850 м. Горные цепи разделены или рассечены узкими речными долинами. Реки типичные горные с большими продольными уклонами, порогами и перекатами. Крутизна склонов здесь меньше, чем на восточном склоне, но обвально-осыпные явления, эрозия, оползни и солифлюкция проявляяются достаточно интенсивно. Расчлененность ландшафтов не превышает чаще всего 150-300 м. Интенсивно проявляется боковая эрозия рыхлых отложений и коренных склонов.

Западный Сихотэ-Алинь охватывает все пространство между Центральным Сихотэ-Алинем и Уссури-Ханкайской равниной. Эта часть горной страны состоит из отдельных хребтов северовосточного простирания (Западный Синий, Восточный Синий, Холодный, Первый Перевал и др.), разделенных межгорными впадинами и рассеченных широкими поперечными речными долинами рек Уссури, Малиновка, Большая Уссурка, Бикин и др. Высоты гор редко превышают 1000 м, склоны более пологие в сравнении с Центральным Сихотэ-Алинем. Эрозионное расчленение не превышает 1 км долин на 1 кв. км площади, относительные превышения чаше всего составляют 50-150 м. К западу горы становятся ниже, и горная страна Сихотэ-Алинь сочленяется с Уссури-Ханкайской равниной.

Восточно-Маньчжурские горы расположены на участке между государственной границей и Уссури-Ханкайской равниной. Ширина их в южной части до 50 км, в северной - до 80 км. Делится на три морфологически самостоятельные части: к северу от долины р. Раздольная располагается Пограничный горный район, к югу - Борисовское базальтовое плато и Хасанско-Барабашский горный район [40, 44, 87, 88 и др.].

Пограничный горный район представляет собой систему небольших по протяженности водораздельных горных хребтов высотой 600-800 м (наивысшая отметка - г. Кедровая, 964 м). Все линии водоразделов по направлению к оз. Ханка понижаются, переходя в низкогорье и холмисто-увалистую равнину. Вертикальная расчлененность местности 200-500 м, горизонтальная - до 1 км на 1 кв. км.

Хасанско-Барабашский горный район, расположенный в югозападной части края, состоит из хр. Черные Горы общего северо-восточного направления и нескольких коротких поперечных водоразделов юго-восточного и южного направления. Долины всех наиболее крупных водотоков этой части края открыты южным и юго-восточным влагонесущим потокам морского воздуха, что накладывает своеобразный отпечаток на климат, почвы и растительность. По абсолютным отметкам (до 900-1000 м) это типичное низкогорье, но с высокой степенью вертикального (300-600 м) и горизонтального расчленения (до 1,5 км на 1 кв. км площади). Реки описываемого района типичные горные. Русла их перегружены аллювием, количество которого возрастает за счет накоплений катастрофических паводков, участившихся в связи с уменьшением общей залесенности территории. В связи с чем на морском побережье сформировалась прибрежная низменная равнина шириной от нескольких десятков метров до 10 км. Над ее ровной заболоченной поверхностью с множеством озер и стариц местами возвышаются останцовые горы абсолютной высотой до 180 м (например, гора Голубиный Утес).

Равнинный класс ландшафтов развит в пределах Уссури-Ханкайской равнины, располагающейся между Восточно-Маньчжурским нагорьем и горной страной Сихотэ-Алинь (рис. 12).

Площадь равнины около $20 \%$ площади края. Центральную (большую по размерам) часть ее составляет Приханкайская равни- 


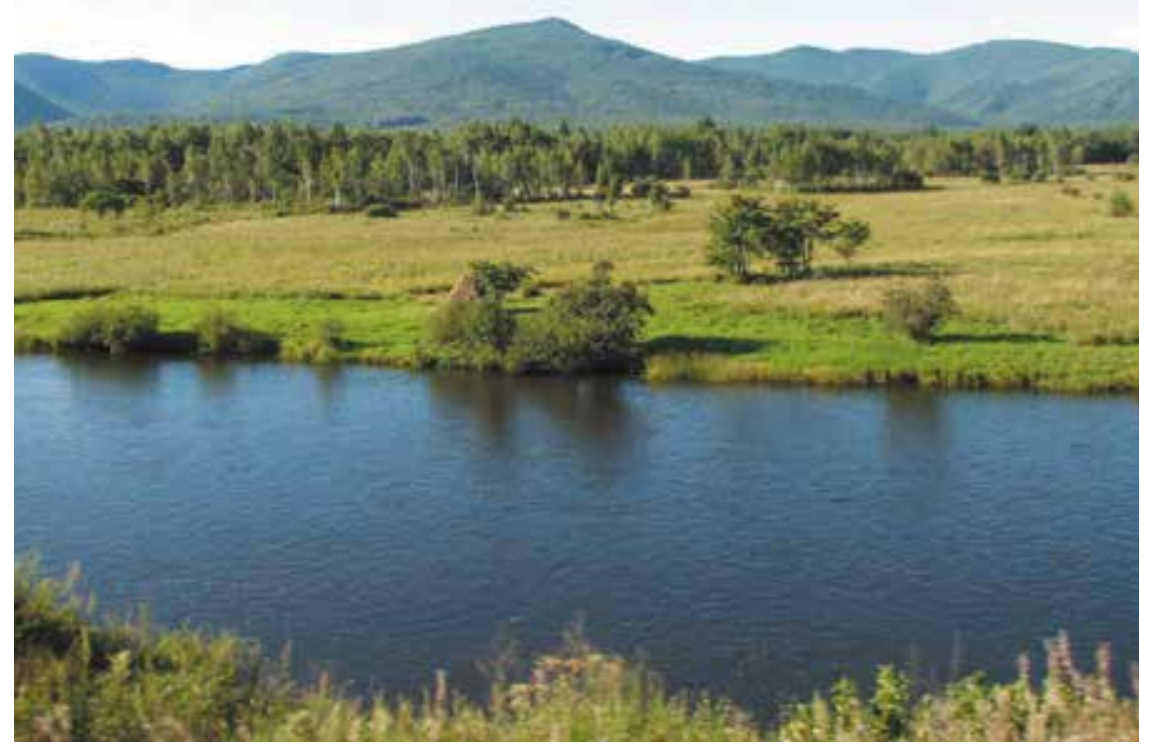

Puc. 12. Уссури-Ханкайская равнина.

На заднем плане - низкогорья Сихотэ-Алиня

на, простирающаяся на 250 км. В ее внутренней части находится о3. Ханка, вокруг которого развиты болота общей площадью в несколько тысяч квадратных километров (рис. 13).

Для Приханкайской равнины характерны отметки 50-80 м, разделенные широкими заболоченными речными долинами, южную часть Уссури-Ханкайской равнины составляет Раздольненская равнина, северную - Нижне-Бикинская. Раздольненская равнина заключает долину р. Раздольная с приустьевыми частями долин ее притоков (рис. 14).

Нижне-Бикинская равнина (рис. 15, 16) образована долиной p. Уссури, на участке от правого водораздела р. Большая Уссурка до устья р. Бикин, и приустьевыми частями долин рек Бикин и Алчан. К западу от Нижне-Бикинской равнины расположен среднегорный хр. Стрельникова.

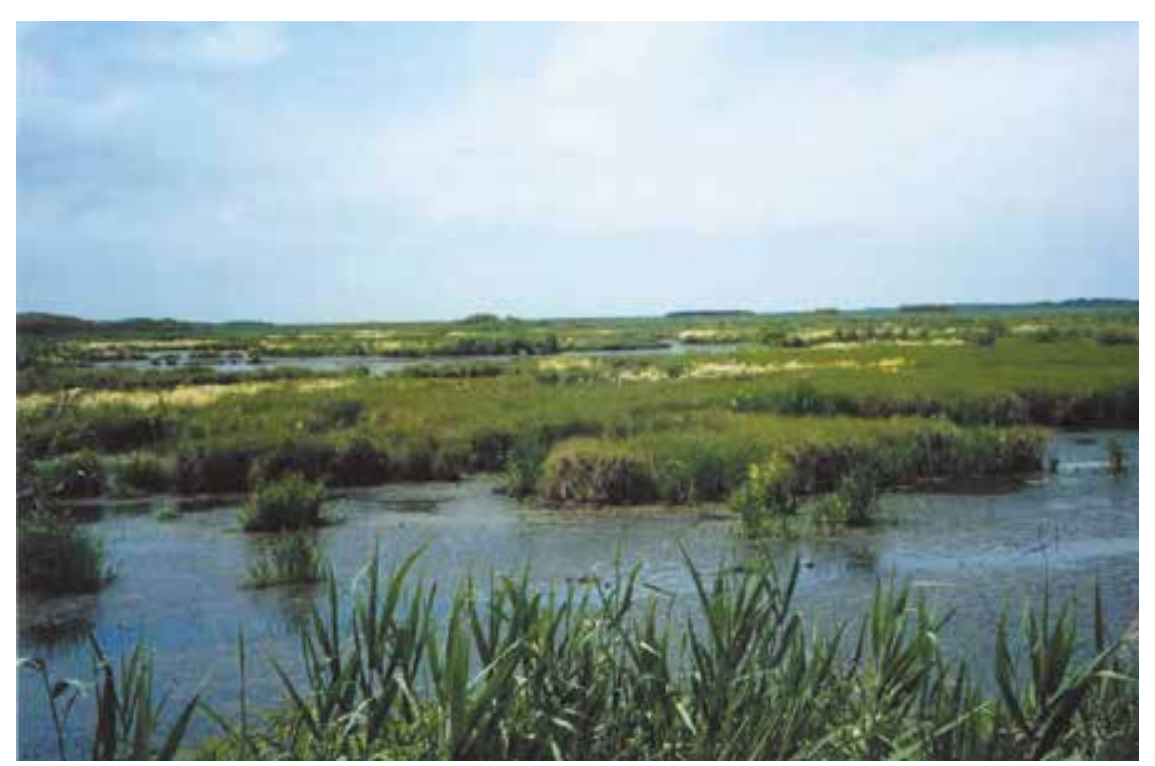

Puc. 13. Болотная местность у оз. Ханка (фрагмент).

Фото В. Солкина

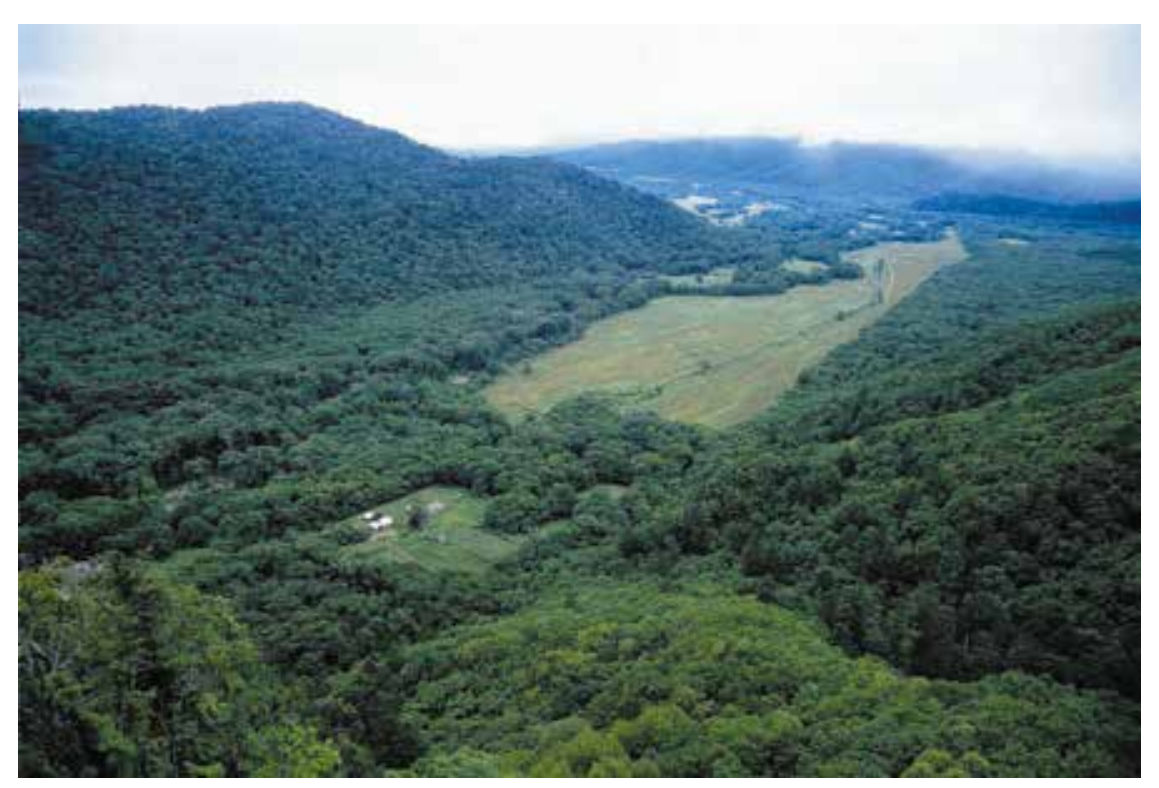

Puc. 14. Ландшафт долины р. Раздольная. Фото Г. Шаликова 


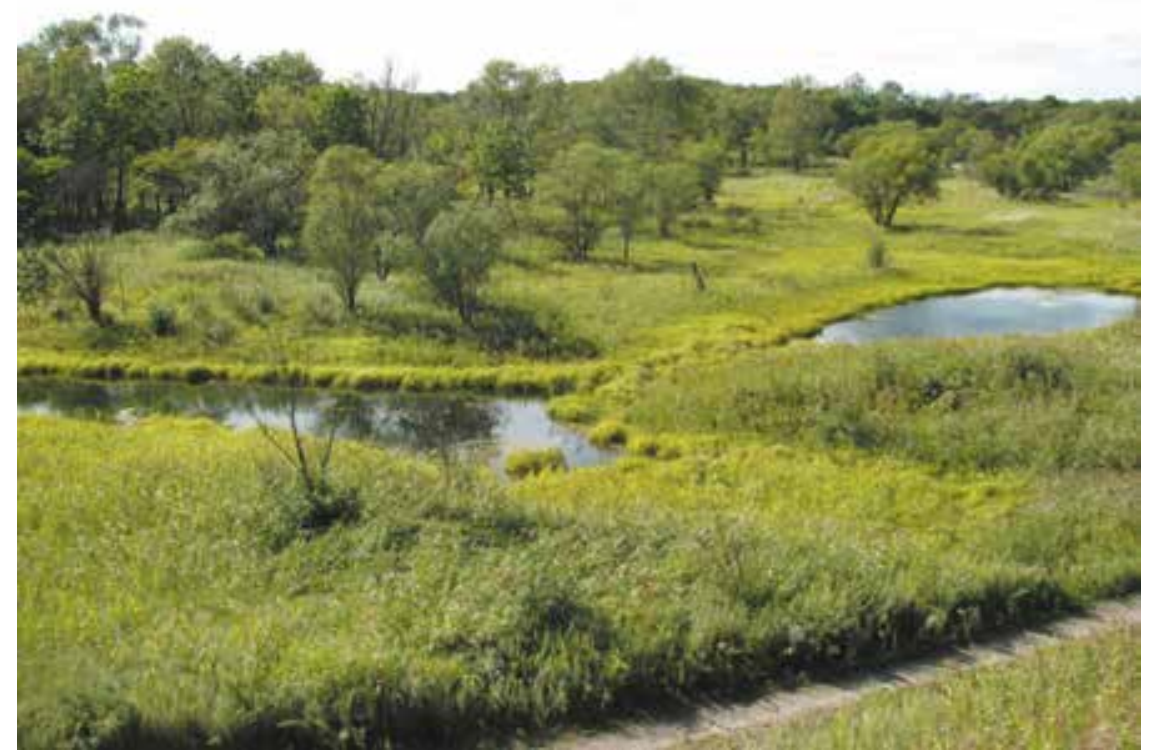

Puc. 15. Долина малого водотока Нижне-Бикинской равнины

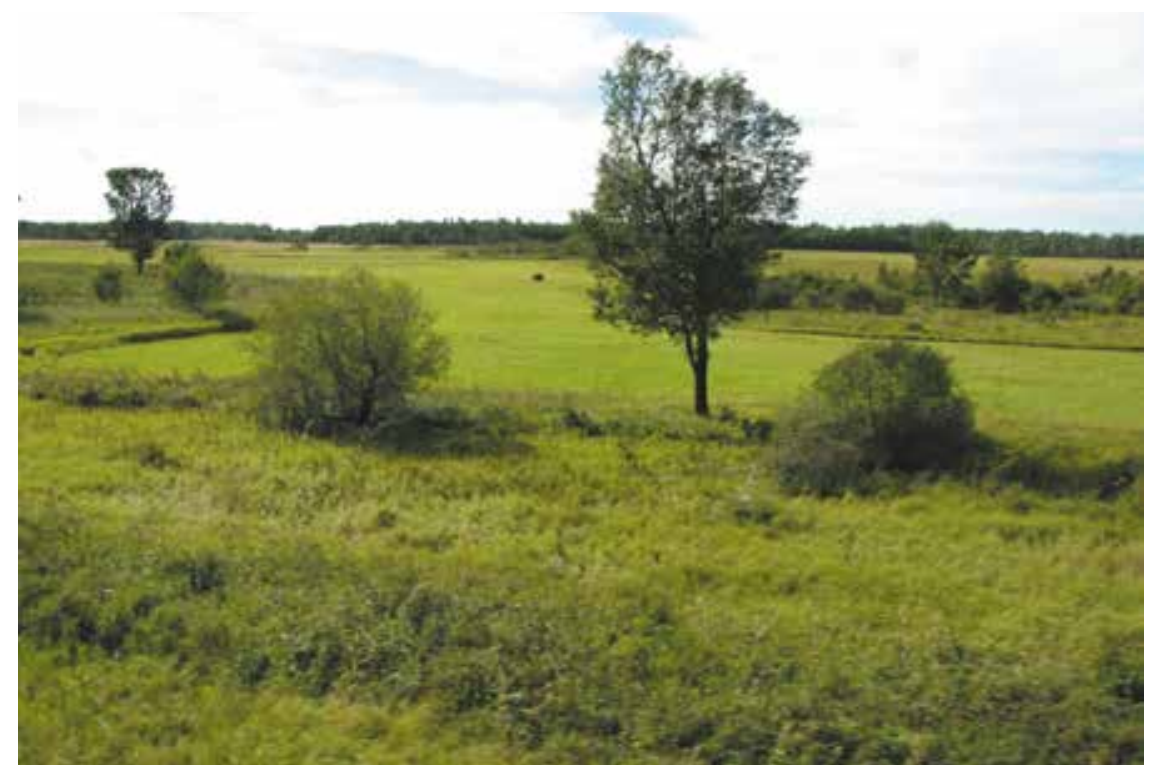

Puc. 16. Общий вид фрагмента ландшафта Нижне-Бикинской равнины.

\section{Контрольные вопросы}

1. Раскройте понятие классы ландшафтов.

2. Охарактеризуйте горный класс ландшафтов Приморья.

3. Охарактеризуйте равнинный класс ландшафтов Приморья.

4. Приведите характеристику Сихотэ-Алинских гор.

5. Что такое Япономорский макросклон Сихотэ-Алиня и приведите его характеристику?

6. Что такое Уссури-Ханкайский макросклон Сихотэ-Алиня и приведите его характеристику?

7. Что такое Центральный Сихотэ-Алинь и приведите его характеристику?

8. Что такое Западный Сихотэ-Алинь и приведите его характеристику?

9. Охарактеризуйте Восточно-Маньчжурские горы.

10. Охарактеризуйте Приханкайскую равнину.

11. Охарактеризуйте Нижнее-Бикинскую равнину. 


\section{Лекция 10}

\section{ОРГАНИЗАЦИЯ И ИЕРАРХИЧЕСКАЯ СТРУКТУРА ЛАНДШАФТОВ}

\section{Подклассы и роды ландшафтов}

Многообразие геологических, геоморфологических и климатических режимов различных частей Приморского края предопределило современное состояние коренного фундамента, пространственное распространение тундровых, таежных, лесных и степных растительных и почвенных группировок. Все эти компоненты во взаимосвязи и взаимообусловленности с климатическим фактором положены в основу выделения горно-тундрового, горно-темнохвойного, горно-лесного смешанно-широколиственного, лесостепного равнинного и долинно-речного подклассов ландшафтов.

Кроме того, уже выделенные подклассы ландшафтов не однородны по субстрату, морфогенетическим типам рельефа, густоте расчленения, глубине эрозионного вреза. По отмеченным критериям, подклассы ландшафтов в свою очередь подразделяются на роды. Горно-тундровый класс - на гольцовый полисубстратный; горно-темнохвойный - на массивно- и расчлененносреднегорный полисубстратные, низкогорный терригенный и вулканогеннотерригенный и платобазальтовый роды; горно-лесной смешанношироколиственный - на массивно- и расчлененносреднегорный полисубстратный, низкогорный терригенный, мелкосопочный полисубстратный и платобазальтовый роды; равнинный и долинно-речной лесостепной - на эрозионно-аккумулятивный равнинный и долинно-речной роды ландшафтов.

Горно-тундровый подкласс и гольцовый полисубстратный род ландшафтов на гольцовых, подгольцово-горных, каменистых россыпях, осыпях, курумах и каменистых потоках, приуроченных к гребням водоразделов, вершинам и склонам гор, развиты не широко, площадь в пределах края около 608 км² $^{2}$ рис. 17, 18). В большинстве случаев это самые возвышенные участки гор,

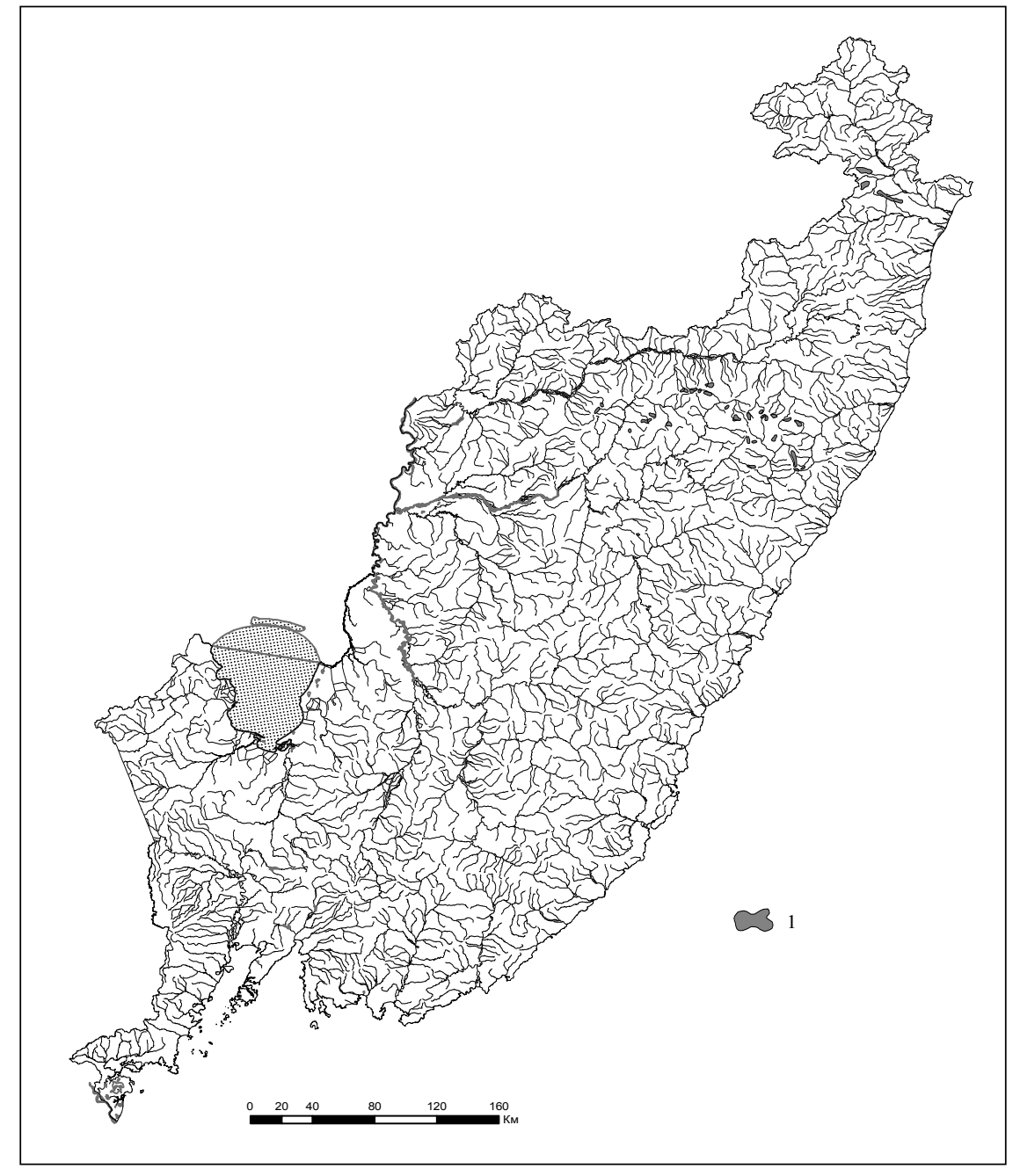

Puc. 17. Распространенность гольцовых полисубстратных ландшафтов горно-тундрового пояса (1)

округлые вершины и террасированные склоны. На северном Сихотэ-Алине ландшафты этого рода и класса довольно часто отмечаются с отметок 700-900 м, на южном - редко опускаются ниже 1100 м. Наиболее часто они развиты на водоразделах рек Бикин, Большая Уссурка, в верховьях р. Уссури и водоразделах рек япономорского макросклона. 


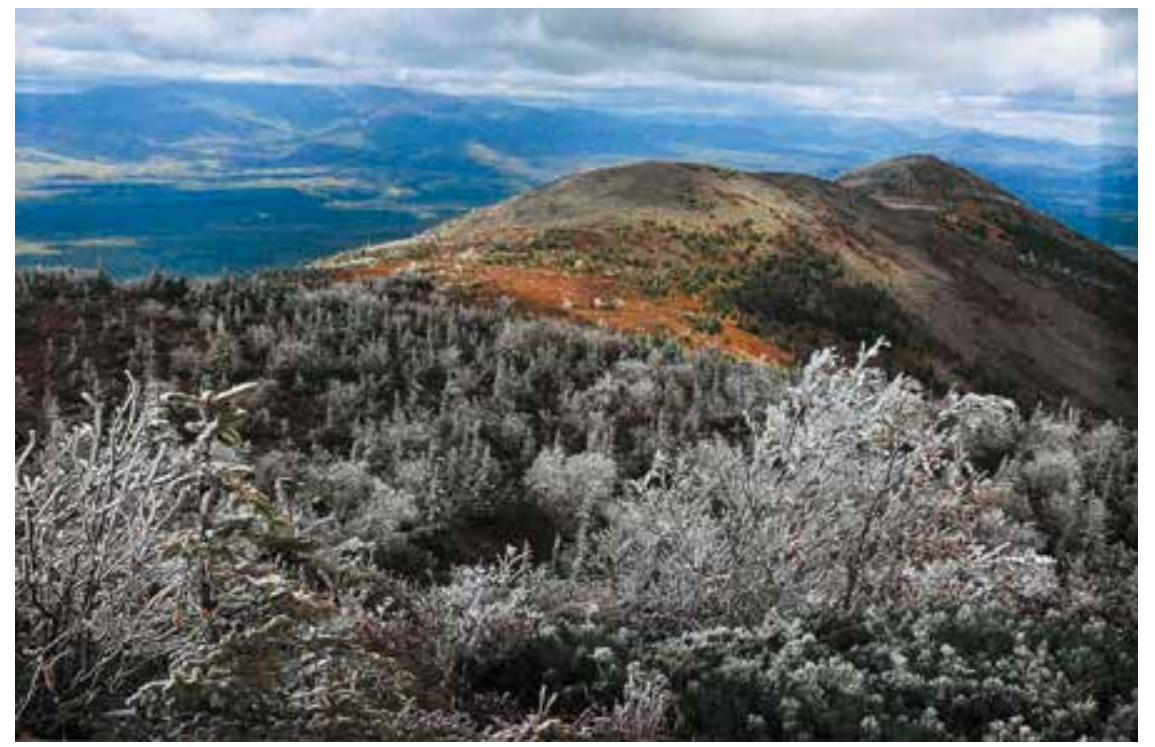

Puc. 18. Общий вид высокогорья. Фото А. Паничева

Фундамент преимушественно вулканогенный, сложенный породами липаритового состава, гранитоидный, реже терригенный, сложенный алевролит-песчаниковым комплексом. Характеризуются маломощным чехлом обломочных накоплений, малым количеством мелкозема в их разрезе, слаборазвитыми фрагментарными каменистыми почвами. В таких условиях глубина промерзания значительно превышает мощность слоя рыхлых накоплений, что приводит к интенсивному развитию явлений отторжения обломков скальных пород и выпучивания их вверх вплоть до дневной поверхности. Этому способствуют продолжительные резкие перепады суточных температур осенью и весной, высокий уровень солнечной радиации, переувлажнение грунтов и длительный режоляционный период свойственный климату Приморского края.

Почвы горно-тундровая в гольцовом и иллювиально-гумусовые и дерново-органические в подгольцовом поясах. Горные тундры характеризуются преобладанием в покрове кустистых лишайников (особенно ягелей). Встречаются одиночные кусты низкорослого кедрового стланика. В зоне подгольцовых частей гор развиты стелющиеся леса кедрового стланика. К местам скопления каменисто-глыбовых отложений склонов всех экспозиций приурочены лишайники.
На мелкокаменистых осыпях среднего Сихотэ-Алиня довольно быстро формируются куртины малины, бузины, спиреи, рододендрона и других кустарников. Из трав отмечаются кипрей, патриния каменная и др. [285]. В южном Сихотэ-Алине на мелкокаменистых осыпях в качестве пионерной растительности отмечаются [31] багульник, жимолость Максимовича, рябинник, актинидия коломинта, бересклет, виноград и др. А в целом восстановление почв и развитие растительности на каменистых россыпях идет чрезвычайно медленно. Этот процесс может быть легко прерван на любой стадии при изменении природной обстановки по причине естественных флуктуаций климата или под воздействием антропогенных факторов.

В целом для горно-тундрового класса и гольцового полисубстратного рода ландшафтов характерно:

- интенсивное проявление и широкое распространение процессов вершинного выравнивания и гольцовой планации;

- активное морозно-мерзлотное, химическое и биологическое выветривание с образованием грубообломочного структурного элювия;

- активный вынос мелкозема в процессе суффозии, солифлюкции и бокового подпочвенного смыва;

- интенсивное проявление курумового, термокрипового и криокрипового транзита грубообломочного материала;

- формирование осовов (камнепадов) на склонах и как следствие быстрое смещение склоновых накоплений на значительные расстояния (вплоть до подножия склонов);

- широкое распространение явлений солифлюкции и морозного выпучивания;

- развитие ложковых и циркообразных форм глубинной эрозии в пределах массивных горных сооружений и каньонообразных в пределах расчлененного горного рельефа;

- формирование хаотически-глыбового и крупновалунного материала в тальвегах эрозионных долин, перемещаемого только в периоды катастрофических ливней, при прорыве горных плотин, при скольжении по поверхности ключевых наледей в период весеннего снеготаяния, при сходе снежных лавин и т.д.;

- густота горизонтального эрозионного расчленения рельефа 0,4-0,8 км на 1 кв. км площади;

- глубина эрозивного вреза до 200-300 м;

- склоны от пологих выпуклых до крутых прямых; 
- значительное количество скальных выходов, устойчивых к выветриванию коренных пород на вершинах, склонах и в каньонах.

Ландшафты горно-темнохвойного подкласса развиты на площади около 20900,7 кв. км. Это среднегорные (массивные и расчлененные) и низкогорные территории с южнотаежными группировками хвойных лесов, с преобладанием ели аянской и пихты белокорой. Верхнюю границу леса в некоторых местах формируют подгольцовые ельники. Преобладающие почвы - горно-таежные бурые. Интенсивно проявляется физическое и химическое выветривание, активный вынос мелкозема в процессе нивации и солифлюкции, преимушественно термокриповый, криокриповый, реже гигрокриповый транзит склоновых накоплений с дифференциацией разреза на верхнюю часть - существенно дресвяно-щебнисто-глыбовую с малым количеством мелкозема или без такового вообще и нижнюю - суглинисто-обломочную. Заметно распространение явлений промежуточной склоновой аккумуляции на перегибах и у подножий склонов. Ландшафты горно-таежного класса по отмеченным выше компонентам и факторам дифференцированы в соответствии с морфологическими типами рельефа, с густотой горизонтального эрозионного расчленения, глубиной эрозионного вреза и скоростью водообмена. Выявленные закономерности дифференциации в структуре и организации горно-темнохвойного подкласса ландшафтов дали возможность провести их систематизацию и выделить в горно-темнохвойном подклассе роды ландшафтов: массивносреднегорный полисубстратный, расчлененносреднегорный полисубстратный, низкогорный вулканогенно-терригенный и платобазальтовый.

Массивносреднегорный полисуб стратный род ландшафтов (рис. 19, 20, 21) характеризуется преобладанием наиболее возвышенных куполовидных массивов и линейно вытянутых горных кряжей, обычно контролируемых выходами на поверхность наиболее устойчивых к выветриванию горных пород, представленных молодыми интрузиями, экструзиями, метосамотическими полями, купольными, ядерными и диапировыми структурами. Распространены вершины округлых очертаний и уплощенные широкие водораздельные перегибы. Расположены в центральном Сихотэ-Алине, на водоразделах Бикина, Большой Уссурки и Уссури. На япономорском макросклоне - в бассейнах рек Самарга, Максимовка, Кема, Серебрянка, Киевка. Это районы таежных группировок хвойных лесов с преобладанием ели аян-

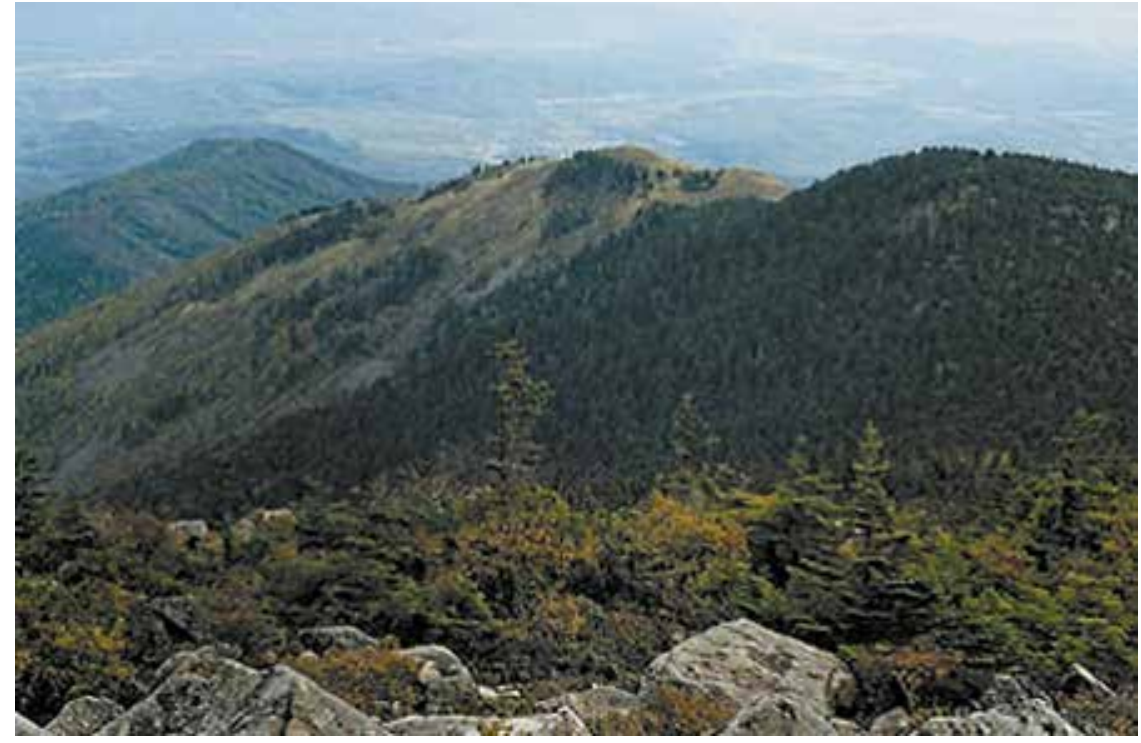

Puc. 19. Общий вид ландшафта массивносреднегорного полисубстратного рода. Фото Г. Шаликова

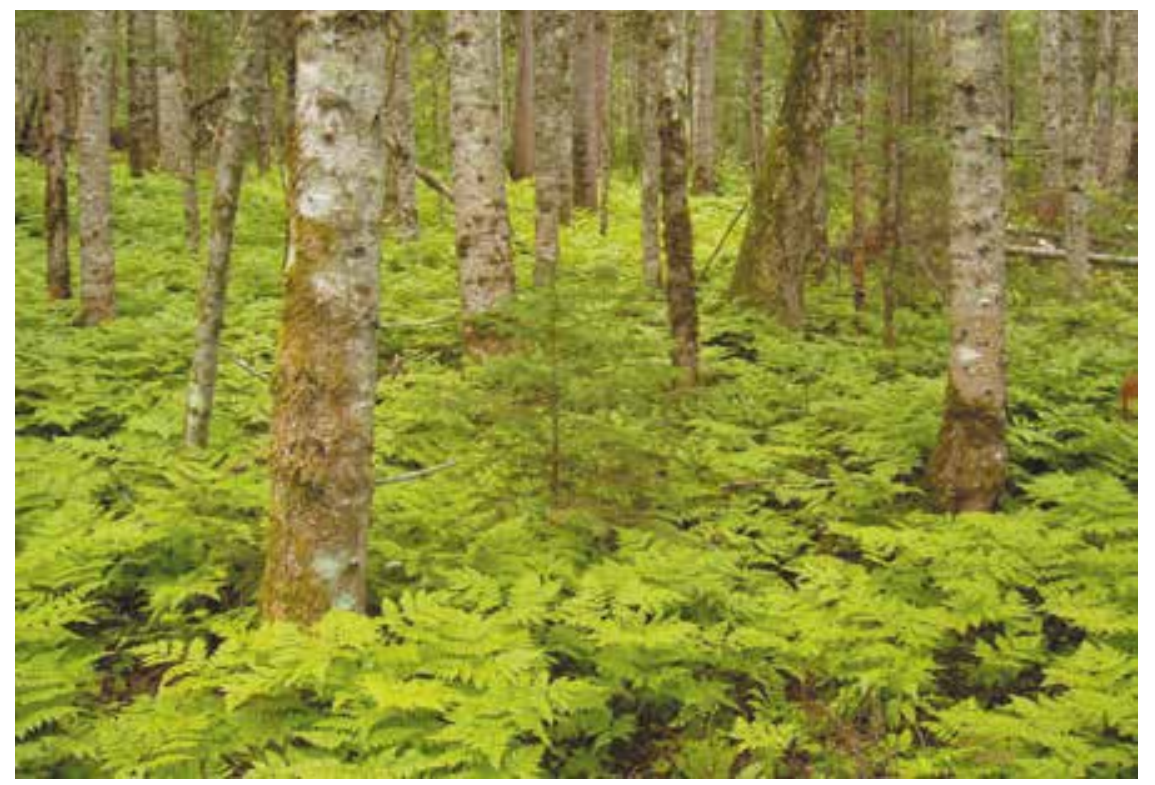

Puc. 20. Хвойные леса нижнего пояса массивносреднегорного полисубстратного рода ландшафтов. Фото А. Паничева 


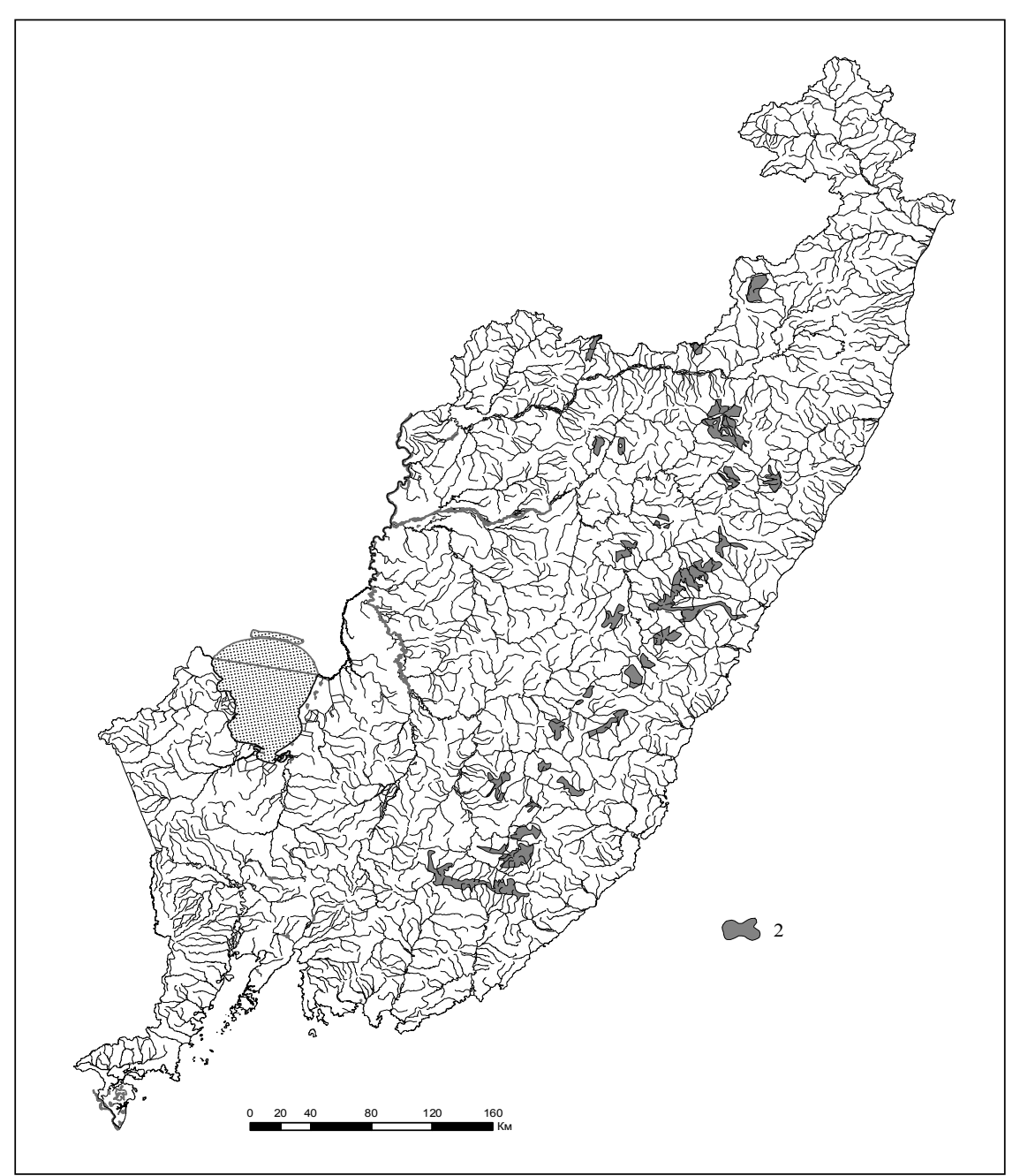

Puc. 21. Распространенность массивносреднегорных полисубстратных ландшафтов горно-темнохвойного пояса (2)

ской и пихты белокорой в хвойной и березы - в лиственной составляющих. Верхнюю границу леса формируют подгольцовые ельники, отличающиеся мощным развитием травянистого покрова и кустарничкового яруса. Преобладающими почвами являются горно-таежные бурые иллювиально-гумусовые, формирующиеся в условиях быстрого водообмена. Растительность формируется на глыбово-дресвяно-щебнистой коре выветривания с относительно высоким содержанием суглинка в разрезе. В целом это области активной денудации и локальной аккумуляции. Кроме того, для массивносреднегорного полисубстратного рода ландшафтов характерно:

- значительное преобладание продуктов физического выветривания в общем объеме мобилизованного обломочного материала зоны разрушения скальных горных пород;

- заметное проявление курумового транзита, осовов, солифлюкции, морозного выпучивания и обвально-осыпных явлений;

- циркообразные формы глубинной эрозии в водосборной зоне и большие продольные уклоны долин в зоне руслового водного транзита обломочного материала;

- густота горизонтального эрозионного расчленения 0,6-1,0 км на 1 кв. км площади;

- глубина эрозионного вреза до 200-300 м;

- формирование крупновалунного материала в тальвегах эрозионных долин;

- малое количество скальных выходов коренных пород;

- выпуклый профиль склонов и средняя их крутизна.

Расчлененносреднегорный полисубстратный род ландшафтов (рис. 22) развит на территории с глубоким расчленением первоначально единых массивов на большое число узких извилистых хребтов и обособленных вершин с глубоко расчлененными склонами. Это территории с резко очерченными водораздельными гребнями, очень крутыми прямыми или выпуклыми в верхней части склонами, к которым на япономорском макросклоне приурочены подвижные осыпи, часто покрывающие склоны от подножья до вершины. Из растительных группировок преобладают кедрово-широколиственные и елово-пихтовые леса. На склонах, поросших древесной растительностью, развиты щебнистые и щебнисто-дресвяные суглинки, служащие минеральной основой преобладающих бурых и желто-бурых почв. Вверх по склону обычно отмечается увеличение количества грубообломочного материала, обогащение им верхней части склоновых накоплений, увеличивается крупность обломочного материала. В целом этот род ландшафтов относится к области активной денудации, но существенную роль играют также процессы аллювиального транзита и промежуточной аккумуляции. Кроме того, для расчлененносреднегорного полисубстратного рода ландшафта характерно: 


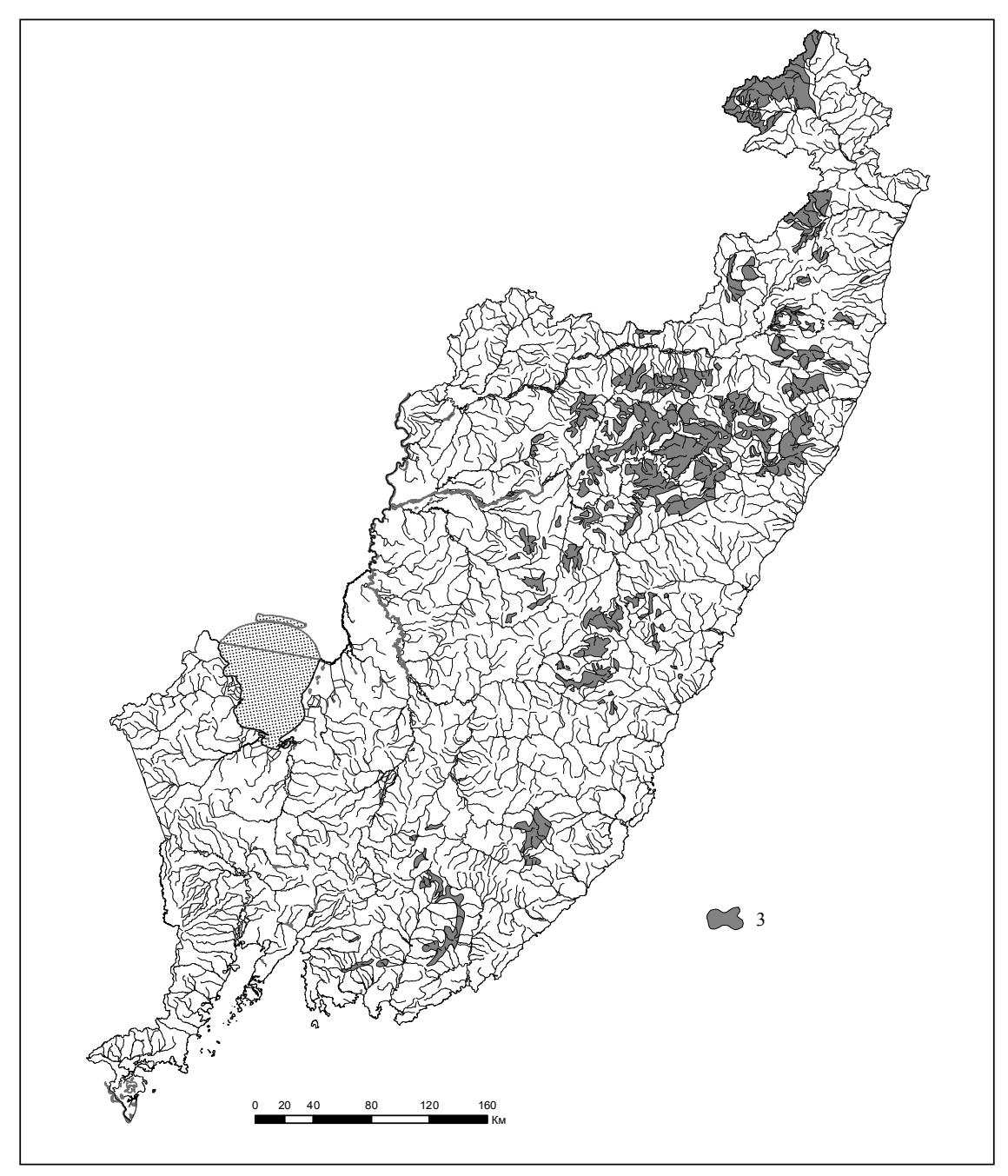

Рис. 22. Распространенность расчлененносреднегорных полисубстратных ландшафтов горно-темнохвойного пояса (3)

- заметное преобладание продуктов физического выветривания в общем объеме мобилизованного материала зоны разрушения скальных пород;

- широкое распространение обвально-осыпных явлений и осовов; - эпизодическое проявление курумового транзита, солифлюкции и морозного выпучивания;
- каньонообразные формы эрозионного врезания вершин водотоков, значительные продольные уклоны долин в зоне руслового водного транзита обломочного материала;

- густота горизонтального эрозионного расчленения 1-2 км на 1 кв. км площади;

- глубина эрозионного вреза 300-700 м;

- формирование крупновалунного и грубогалечного материала, накопление горного аллювия;

- значительное количество скальных выходов коренных пород в виде эрозионных обрывов и денудационных уступов (останцов);

- преимущественно прямой, реже вогнутый, профиль и большая крутизна склонов;

- появление шлейфов склоновой аккумуляции и пролювиальных конусов.

Низкогорный вулканогенно-терригенный род ландшафтов развит фрагментарно в верховьях рек Бикин, Большая Уссурка (рис. 23). Это горы с абсолютными высотами 300-800 м и относительными превышениями до 200-250 м, с характерными прямыми, реже выпуклыми, склонами, покрытыми слоем щебнистых суглинков, мощность которых у подножья гор обычно увеличивается. Включает пихтово-еловые леса на горно-таежных бурых иллювиальногумусовых неоподзоленных и оподзоленных почвах. Фундамент территории сложен алевролит-песчанниковым комплексом, реже встречается вулканогенный кислого состава. Речная сеть низкогорного вулканогенно-терригенного рода ландшафтов имеет транзитный характер для крупных и большинства средних водотоков.

Мелкие и средние водотоки имеют хорошо выраженные аккумулятивные поверхности, четко сочлиняющиеся со склонами. Характеризуется быстрым водообменном на узких водоразделах и крутых склонах, слабо сдержанным - на широких водоразделах и выположенных склонах.

Ландшафт характеризуется замедленной денудацией и активной аллювиальной и склоновой аккумуляцией. Участки его распространения приурочены к морфоструктурам, испытывающим слабое относительное поднятие.

В целом для низкогорного вулканогенно-терригенного рода горно-темнохвойного подкласса ландшафтов характерно:

- примерно равное соотношение продуктов физического и химического выветривания в общем объеме мобилизованного материала зоны разрушения скальных пород; 


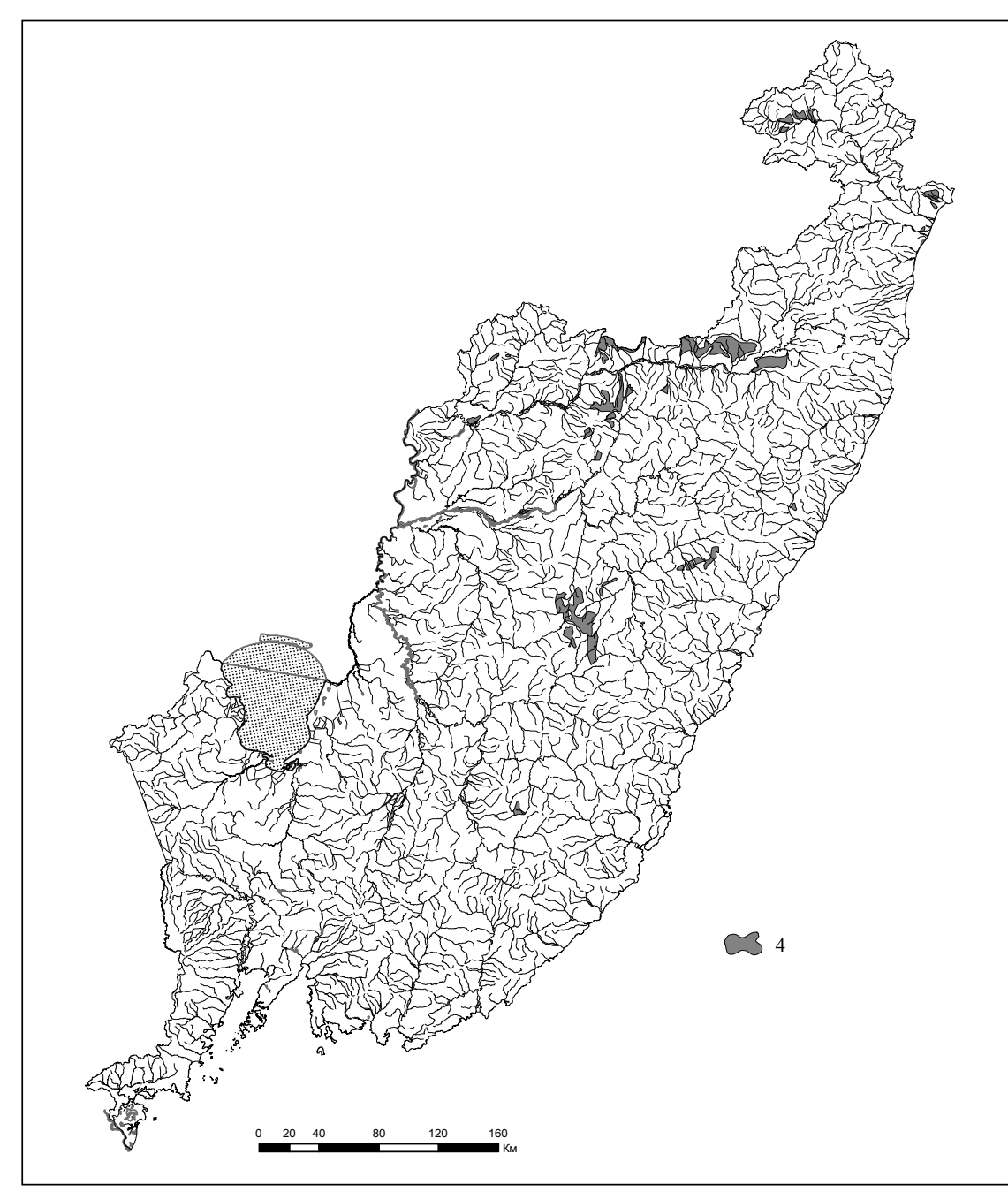

Рис. 23. Распространенность низкогорных вулканогенно-терригенных ландшафтов горно-темнохвойного пояса (4)

- эпизодическое проявление обвально-осыпных явлений и осовов;

- широкое распространение явлений оползания, температурного, криогенного и гигрогенного крипа склоновых накоплений с образованием широких шлейфов промежуточной склоновой аккумуляции в нижних частях склонов;

- ложковые формы врезания вершин водотоков; средние про- дольные уклоны долин в зоне руслового транзита обломочного материала;

- густота горизонтального эрозионного расчленения 0,4-0,8 км на 1 кв. км площади;

- глубина эрозионного вреза 100-400 м;

- накопление гравийно-галечного и гравийно-песчаного материала в тальвегах эрозионных долин;

- малое количество скальных выходов коренных пород;

- прямой или вогнутый профиль склонов и средняя их крутизна.

Платобазальтовый род (рис. 24) включает базальтовые плато с пихтово-еловыми лесами и горно-таежными бурыми, охристо-бурыми и глеевыми почвами, со слабо наклоненными или горизонтальными поверхностями с абсолютными отметками от первых десятков до 1500 м, с обрывистыми уступами и обвально-оползневыми накоплениями в краевых частях. Густота расчленения 0,4-0,8 км на 1 кв. км, глубина вреза от первых метров до прорезания на полную мощность накоплений с углублением в подбазальтовый фундамент. Характеризуется затрудненным водообменном.

На поверхности плато и столовых возвышенностей формируются площадные коры выветривания мощностью от 1-1,5 м до 5-6 м, редко более.

Кора выветривания чаще всего представлена буровато - коричневой глиной с обломками базальта. Количество обломков в поверхностном (подпочвенном) горизонте 10-30\%. С глубиной количество обломков увеличивается до 80-90\% от объема рыхлых накоплений. Степень выветрелости их заметно уменьшается, и уже на глубине $1-1,5$ м в обломках встречается довольно свежий базальт.

В морфогенетическом плане плато базальтов приурочены к зонам различной мобильности: от самых активно воздымающихся до испытывающих современное опускание. В прямой зависимости от этих факторов находятся горизонтальная и вертикальная расчлененность, мощность кор выветривания, обводненность (вернее, дренированность) пород, условия вертикального и горизонтального водообмена.

Горно-лесной смешанно-широколиственный подкласс ландшафтов распространен в крае шире, чем горно-темнохвойный, и занимает площадь около 98250,4 кв. км. Это среднегорные (массивные и расчлененные), низкогорные, мелкосопочные территории со 


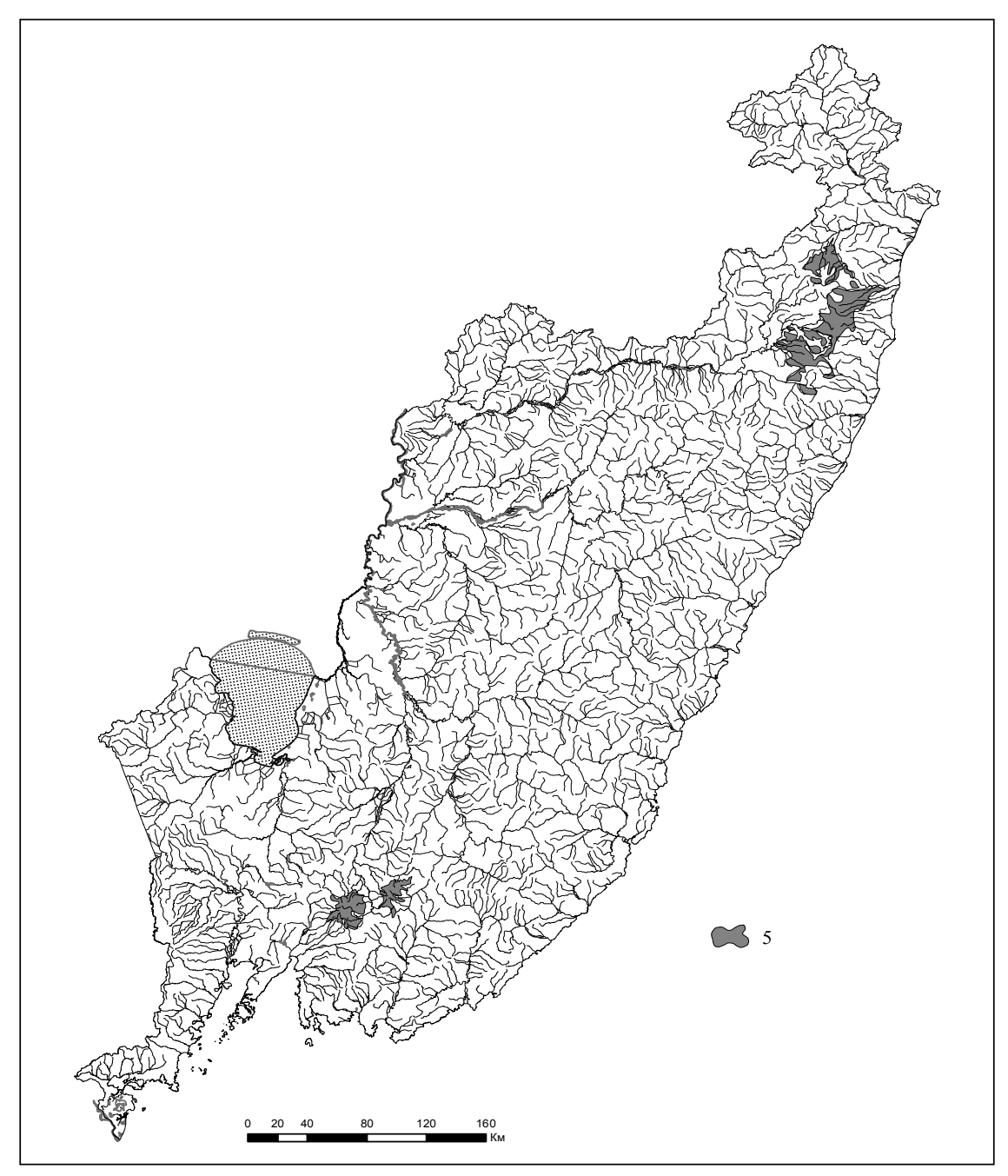

Pис. 24. Распространенность платобазальтовых ландшафтов горно-темнохвойного пояса (5)

сложной дифференцированностью растительных и почвенных группировок. Включает хвойно-широколиственные и широколиственные леса (гл. 2 на преобладающих лесны бурых, бурых лесных почвах (гл. 2). Интенсивно проявляется химическое и физическое выветривание, замедлен боковой вынос мелкозема в процессе суффозии и бокового подпочвенного смыва, прео- бладает термокриповый и гигрокриповый транзит склоновых накоплений при сохранении их преимущественного суглинистого состава. Характерно широкое распространение явлений промежуточной склоновой аккумуляции на изгибах и у подножий склонов.

Поиск закономерностей в структуре и организации ландшафтов по отмеченным выше особенностям обнаруживает их дифференциацию в соответствии с геологическим строением, морфологическими типами рельефа, с густотой горизонтального эрозионного расчленения, глубиной эрозионного вреза и скорости водообмена. Выявленные закономерности дифференциации ландшафтов дали возможность провести их систематику, классифицировать и выделить в горно-лесном смешанно-широколиственном подклассе роды ландшафтов: массивносреднегорный полисубстратный, расчлененносреднегорный полисубстратный, низкогорный терригенный, мелкосопочный полисубстратный и платобазальтовый.

Массивносреднегорный (рис. 25) и расчлененносреднегорный (рис. 26) полисубстратные роды.

Массивносреднегорный полисубстратный род горно-лесного смешанно-широколиственного подкласса, как и массивносреднегорный горно- темнохвойного подкласса ландшафтов, распространены на более возвышенных куполовидных массивах линейно-вытянутых горных кряжей, они часто гипсометрически располагаются ниже массивносреднегорного полисубстратного рода горно-темнохвойного подкласса; такое их расположение подчеркивает высотную поясность в их распространении в крае. Наибольшие площади приурочены к южной части центрального Сихотэ-Алиня и Южному Приморью. Для этих территорий характерны выпуклый профиль склонов и средняя их крутизна, слабосдержанный водообмен. Густота расчленения 0,6-1,0 км на 1 кв. км, густота вреза 200-300 м.

Расчлененносреднегорный полисубстратный род ландшафтов развит шире, чем массивносреднегорный (рис. 27). Занимает преимущественно япономорских макросклон и имеет фундамент, сложенный вещественными комплексами вулканических горных пород Восточно-Сихотэ-Алинского вулканического пояса, встречаются блоки, сложенные кремнисто-карбонатно-песчаниковоалевролитовым комплексом. Это уже интенсивно расчлененные территории с контрастными элементами рельефа и большой крутизны склонами, четкими водораздельными гребнями и эрозионными долинами. 


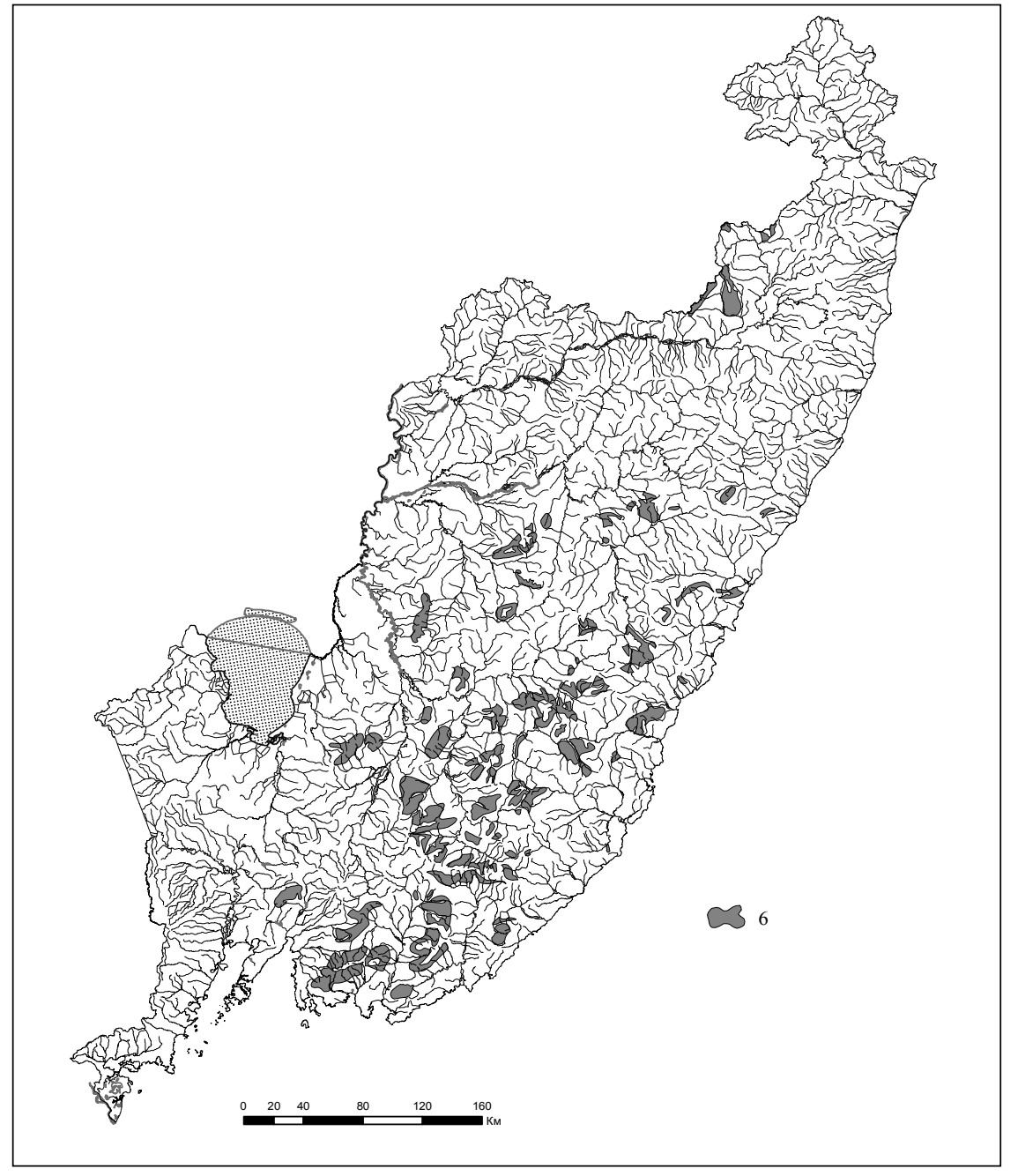

Рис. 25. Распространенность массивносреднегорных полисубстратных ландшафтов горно-лесного смешанно-широколиственного пояса (6)

В целом массивно- и расчлененносреднегорный полисубстратные роды ландшафтов характеризуются сложной дифференцированностью растительных и почвенных группировок. В растительном компоненте развиты хвойно-широколиственные и широколиственные леса, среди почв преобладают лесные, бурые, бурые-лесные. Характеризуются ландшафты замедленным боковым

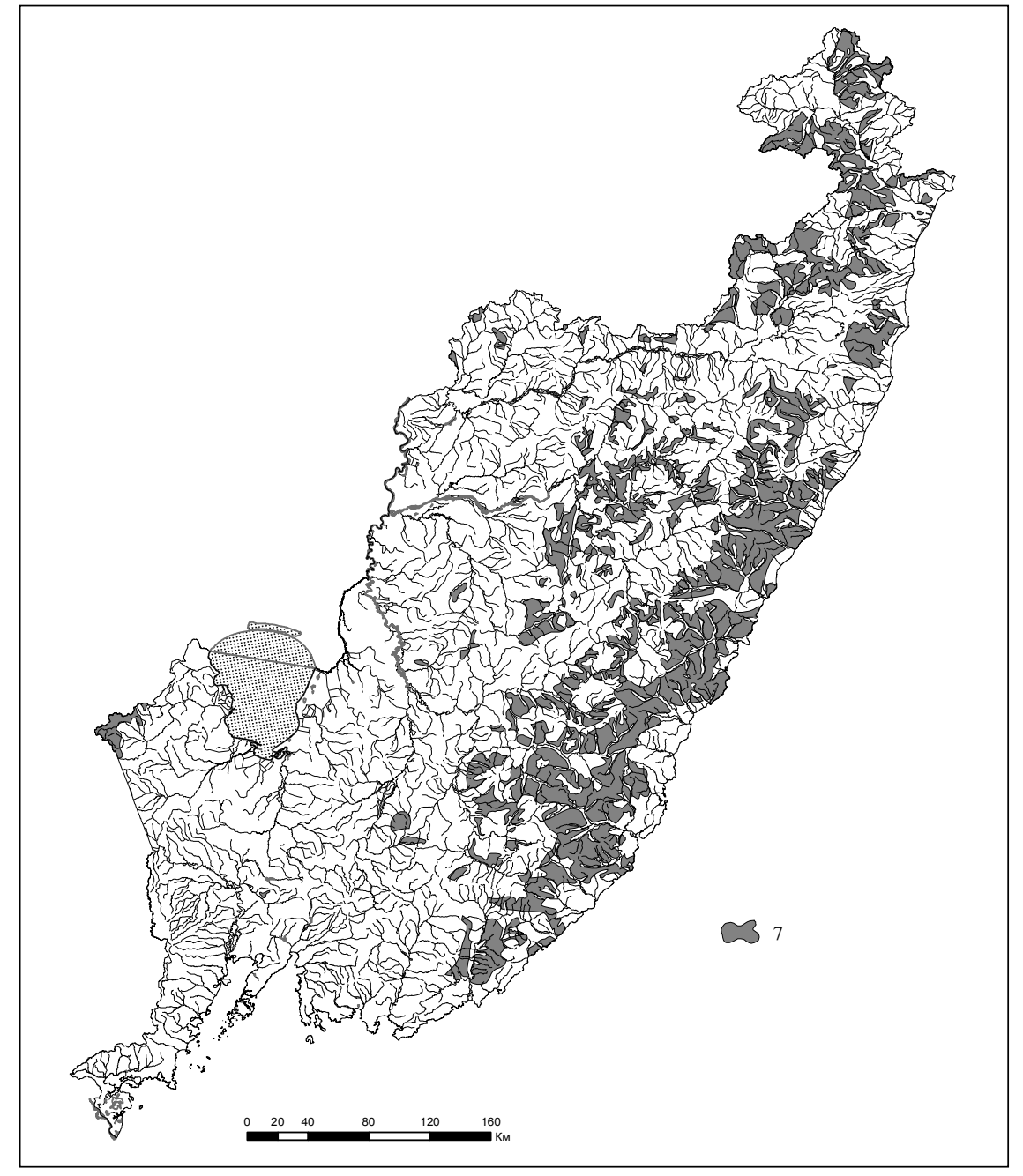

Рис. 26. Распространенность расчлененносреднегорных полисубстратных ландшафтов горно-лесного смешанно-широколиственного пояса (7)

выносом мелкозема в процессе суффозии и бокового почвенного смыва, преобладающим термокриповым и гигрокриповым транзитом склоновых накоплений, с заметным обогащением верхних слоев разреза грубообломочным материалом. Относятся к области активной денудации, но существенную роль играют также процессы аллювиального транзита и промежуточной аккумуляции. 


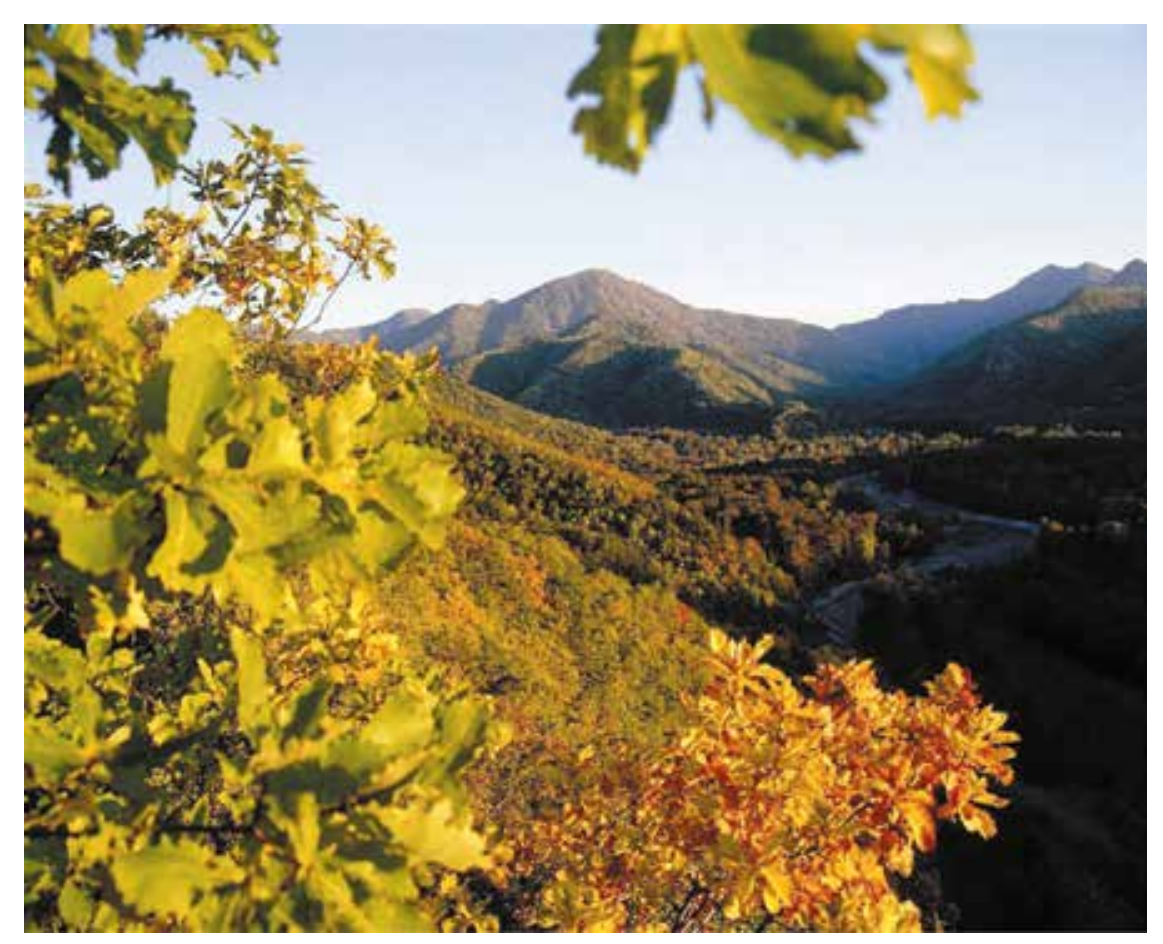

Puc. 27. Фрагмент расчлененносреднегорного полисубстратного ландшафта. Фото А. Паничева

Низкогорный терригенный род горно-лесного смешанно-широколиственного подкласса ландшафтов распространен широко на западном макросклоне Сихотэ-Алиня, Восточно-Маньчжурском нагорье и узкой прибрежной полосе япономорского макросклона (рис. 28).

Это горы с абсолютными отметками 300-800 м и относительными превышениями до 200-250 м. По контрастности элементов (крутизна склонов, четкость водораздельных гребней и эрозионных долин) низкогорные районы в общих чертах сходны с расчлененными среднегорными территориями. Для них характерны прямые, реже выпуклые, склоны, покрытые мощным слоем щебнистых суглинков, мощность которых у подножий гор обычно увеличивается. Обнажение отмечаются редко. Это обычно либо денудационные останцы и гребни, сложенные устойчивыми к выветриванию горными породами на вершинах и склонах, либо эрозионные (абразионные) обрывы у подножий гор.

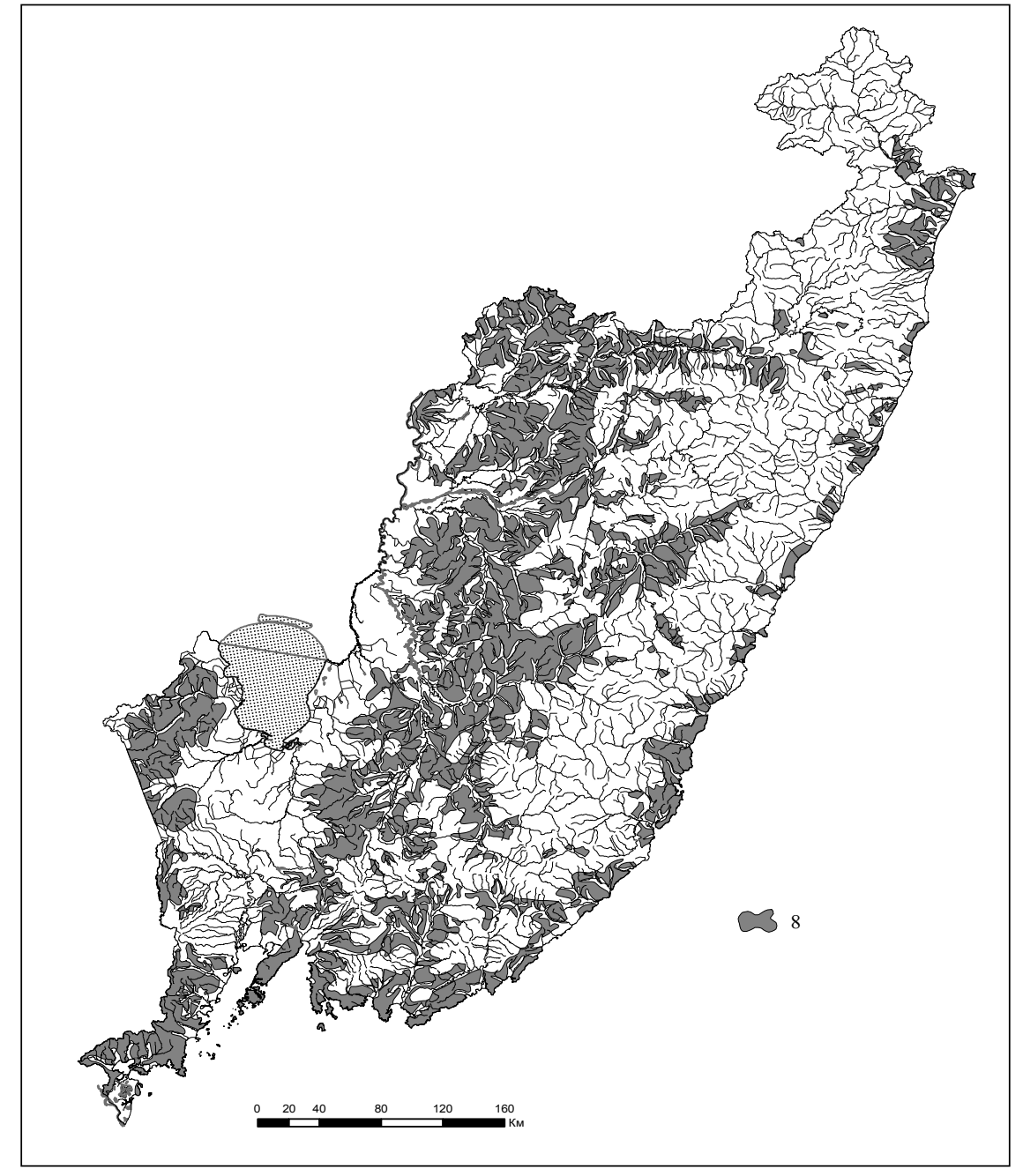

Рис. 28. Распространенность низкогорных терригенных ландшафтов горно-лесного смешанно-широколиственного пояса (8)

В составе коренного фундамента на западном макросклоне Сихотэ-Алиня преобладают алевролитово-кремносто-вулканогенный, сланцевый кремнисто-глинистый и вулканогенно-кремнисто-алевролитово-вещественные комплексы. На Восточно-Маньчжурском низкогорье - гранитоидный, вулканогенный, участками сланцевый, алевролит-песчаниковый, песчаниково-алевролитовый 
и другие вещественные комплексы. В Южном Приморье метагаброидный, гранитоидный алевролит-песчаниковый, песчаниково-алевролитовый с конгломератами и гравелитами и другие комплексы.

В целом низкогорный терригенный род ландшафтов характеризуется сложной дифференцированностью растительных и почвенных группировок, среди растительных преобладают широколиственные леса, а в почвенных - бурые-лесные. С замедленным боковым выносом мелкозема в процессе суффозии и бокового почвенного смыва, преобладающим термокриповым и гигрокриповым транзитом склоновых отложений, с заметным обогащением верхних слоев разреза грубообломочным материалом при сохранении их преимущественно суглинистого состава. Широко распространены явления промежуточной склоновой аккумуляции на перегибах и у подножьев склона. Территории относятся к участкам с замедленной денудацией и активной аллювиальной и склоновой аккумуляцией.

Мелкосопочный полисубстратный род горно-лесного смешанношироколиственного подкласса ландшафтов распространен на территориях, обрамляющих Уссури-Ханкайскую равнину (рис. 29).

На востоке равнины, в переходной зоне к Западно-СихотэАлинской низкогорной области это отдельно стоящие возвышенности или гряды, разделенные аккумулятивными долинами. К югу их количество увеличивается, а на западе равнины они распространены значительно шире. Характерная черта гор - различная крутизна верхней $\left(15-20^{\circ}\right)$ и нижней $\left(3-4^{\circ}\right)$ частей склонов, их вогнутый, реже прямой, профиль склонов и малая крутизна, отсутствие скальных выходов коренных пород.

С поверхности сложены полигенетическими накоплениями, преимущественно глинами, представляющими собой типичный делювий, перемещающийся в разрезе и по площади, с накоплением в местах логов, балок, эрозионных борозд, рытвин временных потоков и пр. В общем объеме мобилизационного материала зон разрушения скальных пород резко преобладают продукты химического выветривания, распространен плоскостной смыв с образованием делювиальных шлейфов. В нижней части склонов развиты ложбинно-лощинные формы врезания вершин водотоков.

Фундамент полигенетический, сложен гранитоидным, кремнисто-карбонатным, сланцево-карбонатным, сланцевым, алевролитпесчаниковым, липаритовым вещественными комплексами. Развивается в условиях Амуро-Ханкайской рифтогенной структуры.

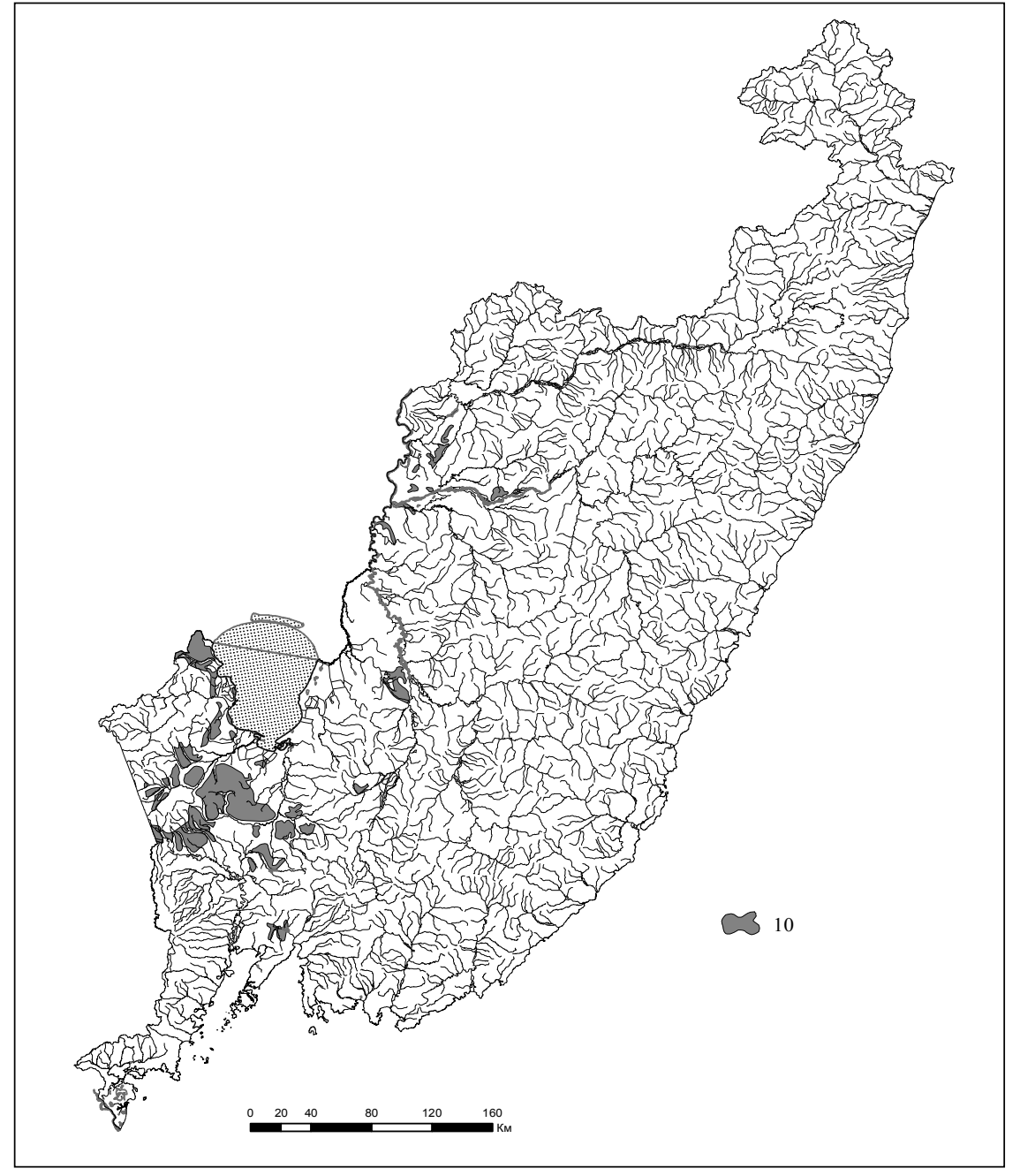

Puc. 29. Распространенность мелкосопочных полисубстратных ландшафтов предгорно-низкогорного пояса Восточно-Маньчжурских и Сихотэ-Алинских гор (10)

Характеризуется ландшафт сложной дифференцированностью растительных и почвенных группировок. Дубовые леса из дуба монгольского, их редколесья и порослевые заросли на горно-лесных бурых, слабокислых неоподзоленных и оподзоленных слабокислых, лесных-бурых кислых и других почвах распространены в северо-восточной части обрамления равнины. 
Южнее на правобережье среднего течения р. Раздольная остепненные редколесья дуба монгольского и березы даурской, дубоволещинно-леспе-децевые заросли в комплексе со злаково-разнотравно-суходольными лугами и фрагментами луговых и горных степей на горно-лесных бурых, бурых слабокислых, глеевато-отбеленных и других почвах.

На западе Приханкайской равнины в зоне перехода к низкогорной Восточно-Маньчжурской территории представлены остепненные редколесья широколиственных лесов и освоенные земли на месте преобладания в прошлом широколиственных лесов и их редколесий, порослевых зарослей (вдоль русел рек) с вейниковыми, с осоково-вейниковыми, разнотравно-злаковыми лугами и низинными осоковыми болотами и освоенные земли на месте луговых степей, естественных лугов, редколесий и порослевых зарослей на горно-лесных бурых, оподзоленных и слабокислых неоподзоленных, бурых слабокислых, бурых глееватоотбеленных, лугово-бурых и других почвах.

В целом мелкосопочный полисубстратный род ландшафтов - области замедленной денудации и активной аллювиальной и склоновой аккумуляции при мобилизации материала в зоне разрушения коренного фундамента. Эпизодически отмечено проявление оползания, температурный, криогенный и гигрогенный крип склоновых накоплений.

Платобазальтовый род (рис. 30) выделяется как часть хорошо сохранившихся в Приморском крае базальтовых плато. Наиболее обширные из них плато Самаргинское - 130 кв. км; Иссиминское - более 850 кв. км; Единкинское - 310 кв. км; Зевинское (Верхнебикинское) - 2920 кв. км; Максимовское - 550 кв. км; Борисовское - 1480 кв. км; Илистое - 250 кв. км; Шкотовское 1110 кв. км; Арсеньевско-Партизанское - 610 кв. км; Верхнепартизанское - 120 кв. км. Общая площадь, занятая базальтовыми плато и столовыми горами, экранизированными базальтами, составляет более 11200 кв. км, или около 7\% всей территории края. Базальтовые плато сохранились в среднегорных и низкогорных высотных поясах.

Базальтовые плато имеют современную поверхность, слабонаклонную в сторону моря или иного регионального базисного понижения. В пределах плато сохранились куполовидные возвышенности, являющиеся остатками разрушенных околократерных сооружений. Иногда среди плато поднимаются возвышенности

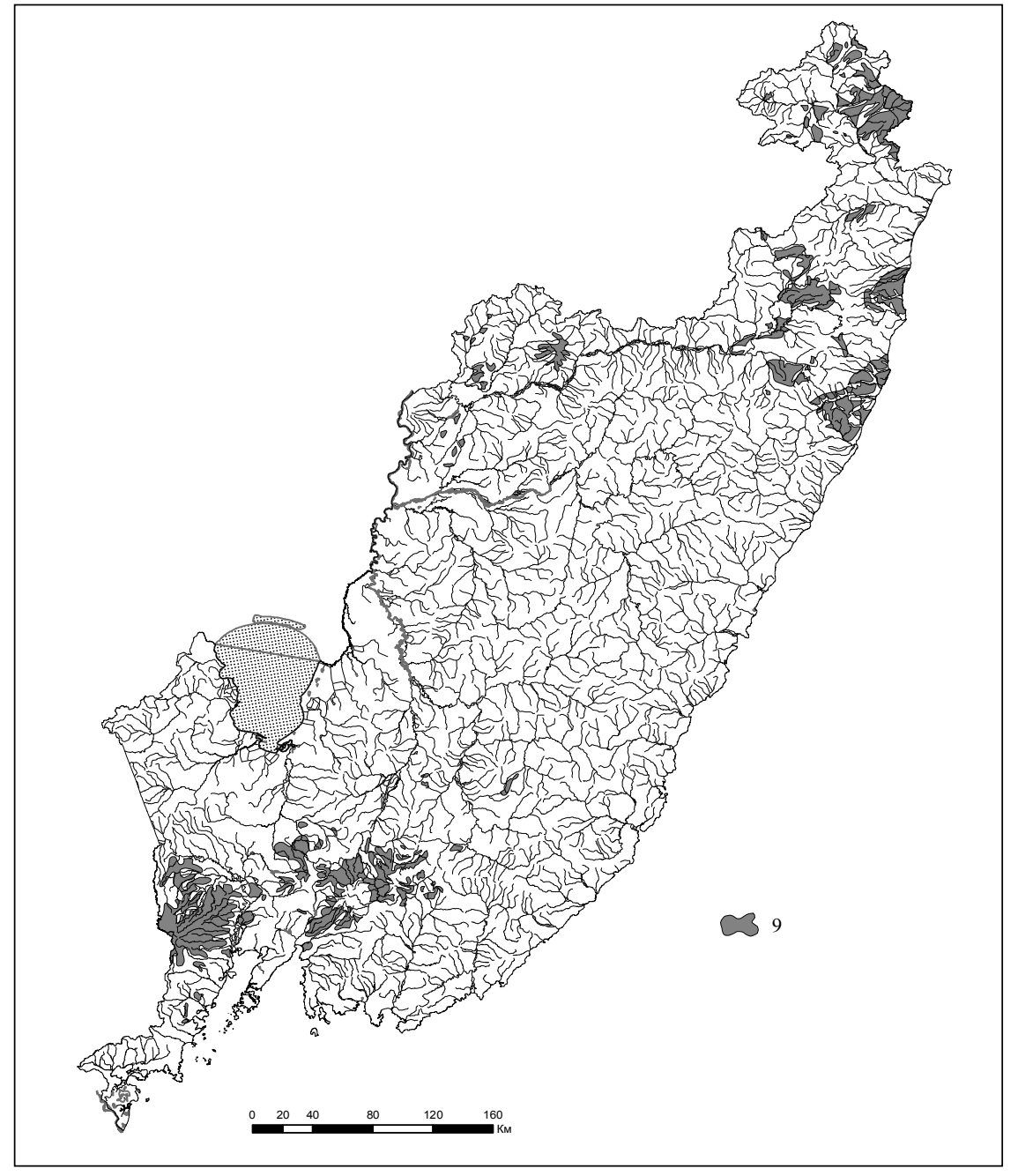

Puc. 30. Распространенность платобазальтовых ландшафтов горно-лесного смешанно-широколиственного пояса (9)

древнего добазальтового рельефа, сложенные интрузивными, эффузивными или осадочными породами.

На плоской поверхности плато иногда встречаются бессточные впадины или понижения с затрудненным дренажем. Они, как правило, заболочены или сильно переувлажнены. К долинам рек и морскому побережью плато обрываются крутыми скали- 
стыми уступами. Их непосредственным продолжением являются обширные шлейфы обвально-оползневых накоплений, имеющие ширину в сотни и даже тысячи метров. Расчленяющие плато долины крупных водотоков обычно имеют каньонообразный характер. В периферических частях плато, сильно расчлененных эрозионными долинами, формируются изолированные от плато участки - столовые горы.

На поверхности плато и столовых возвышенностях формируются площадные коры выветривания мощностью от 1-1,5 м до 5-6 м, редко более. Кора выветривания чаще всего представлена буровато - коричневой глиной с обломками базальта. Количество обломков в поверхностном (подпочвенном) горизонте 10-30\%. С глубиной количество обломков увеличивается до 80-90\% от объема рыхлых накоплений. Степень выветрелости их заметно уменьшается, и уже на глубине 1-1,5 м в обломках встречается довольно свежий базальт.

В целом для ландшафтов базальтовых плато характерны:

- значительная общая мощность накоплений, экранирующих добазальтовый фундамент и многослойное строение толщ;

- площадное распространение кор выветривания глинистого состава;

- ровные слабонаклонные поверхности водораздельных пространств;

- ложбинно-мочажинные формы врезания вершин водотоков и каньонообразные долины в зоне аллювиального транзита;

- широкое развитие оползневых и обвально-осыпных процессов в краевых частях плато и по бортам эрозионных долин;

- густота эрозионного расчленения от 0 до 0,5-0,8 км на 1 КВ. КМ;

- глубина эрозионного вреза от первых метров до прорезания на полную мощность накоплений с углублением в подбазальтовый субстракт (общая амплитуда может достигать 400-600 м);

- накопление глыбово-валунного материала в верховьях транзитных водотоков и быстрое исчезновение базальтов в аллювии по мере удаления от границы покрова;

- широкое распространение коренных выходов базальтов по краям денудационных уступов и чрезвычайно редкие выходы коренных пород.

Лесостепной равнинный и долинно-речной подкласс ландшафтов, развитый на территории Уссури-Ханкайской равнины, примор- ских (прибрежных) равнин и речных долинах горных районов с преимущественно широколиственными лесами и степными растительными и почвенными группировками, распространен на площади 41811,7 кв. км. Общее для этого подкласса ландшафтов - преобладание эрозионного или абразионного (для прибрежных районов) происхождения рыхлого (обломочного) материала, преимущественно водный его транзит и накопление в условиях малых уклонов поверхностей, химическое выветривание пород фундамента, интенсивное проявление суффозии, бокового почвенного смыва, водная и ветровая эрозия почв, накопление суглинистых и глинистых толщ на пониженных пространствах, заиление водоемов. Поиск факторов дифференциации и закономерностей структуры и пространственной организации подкласса ландшафтов по морфологическим типам рельефа, с учетом многообразия форм речных долин, межгорных котловин, приозерных равнин, густоте горизонтального эрозионного расчленения, глубине эрозионного вреза и скорости водообмена дал возможность установить, что по этим компонентам и факторам лесостепной равнинный и долинно-речной подкласс ландшафтов разделяется на роды: равнинный эрозионно-аккумулятивный и долинный (рис. 31), а также приморско-равнинный.

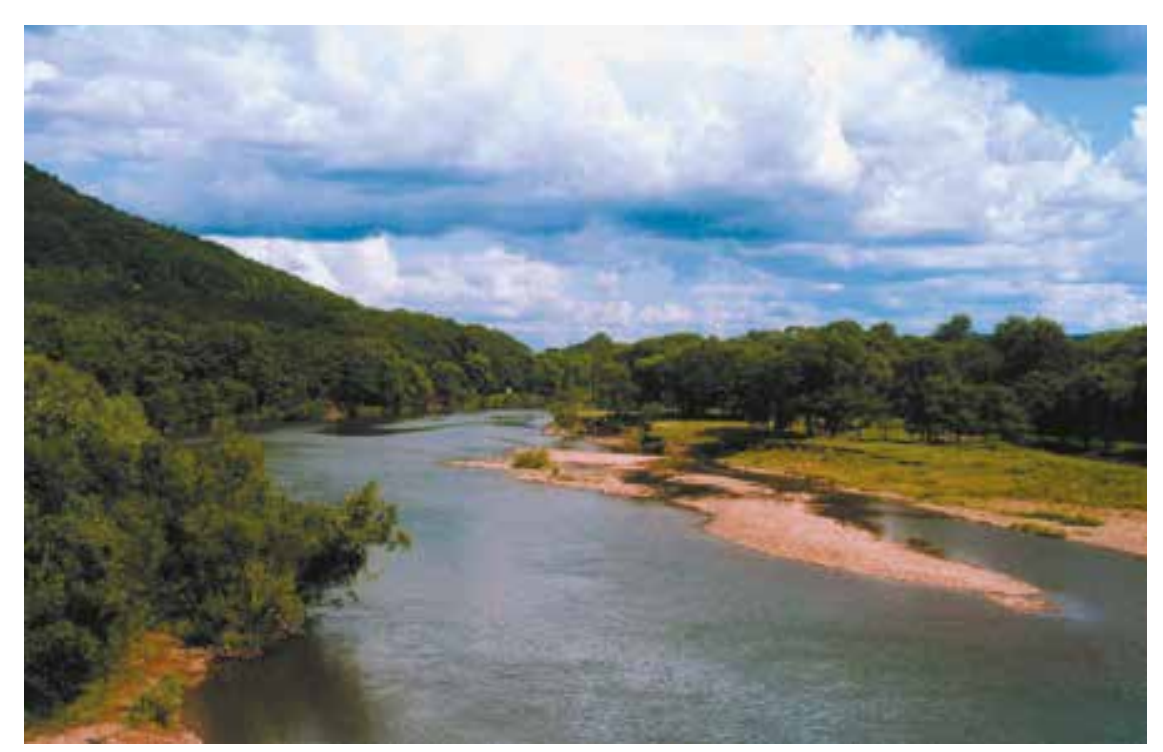

Puc. 31. Общий вид равнинного зрозионно-аккумулятивного долинно-речного ландшафта. Фото О. Кабалика 
Равнинный эрозионно-аккумулятивный и долинно-речной род ландшафтов распространен на площади 42707,1 кв. км. В организации ландшафтов устанавливается общее - преобладающее эрозионное происхождение рыхлого чехла фундамента и в основном водный транзит его рыхлых накоплений. Наблюдаются дифференциация и закономерности в пространственной организации ландшафтов в зависимости от интенсивности донной эрозии, крутизны, расчлененности и экспозиции примыкающих склонов, состояния растительности и состава рыхлых накоплений склонов, типа русловых деформаций, гидрогеоморфологических особенностей водотоков и, в зависимости от этих факторов, приуроченности к разновозрастным и разногенетическим типам озерных и речных террас, пойм с водообменном от быстрого до затруднительного. Рассматриваемые ландшафты приурочены к территориям развитых в Приморье террас: нижне-, средне-, верхнечетвертичного, современного возрастов и современным нетеррасированным накоплениям эрозионно-аккумулятивной природы, представленных низкой поймой рек, озерными поймами и пляжем (геолого-съемочные фондовые материалы масштаба 1:50000 по Приморскому краю и данные автора по шести листам геолого-съемочных работ; [40, 44, 118 и др.]).

Террасы нижнечетвертичного возраста отмечаются в пределах Уссури-Ханкайской равнины и по долинам крупных рек в горном классе ландшафтов. Относительная высота территории 40-60 м. Ширина террасовых зон от первых десятков метров в горных долинах до нескольких километров на Уссури-Ханкайской равнине. В поясах среднегорий и низкогорий террасы долин почти повсеместно скульптурные, в зоне мелкосопочников и на равнинах - аккумулятивные. В междуречье рек Раздольная и Абрамовка комплексы нижнечетвертичной террасы занимают современный водораздел бассейнов р. Раздольная и оз. Ханка. Поверхность террасовых ландшафтов расчленена оврагами, балками, речными долинами (рис. 32).

Террасы среднечетвертичного возраста занимают значительно меньшую площадь. Относительная высота их поверхности 15-20 м, ширина в пределах Уссури-Ханкайской равнины до 15 км, а в долинах рек - десятки и первые сотни метров. В пределах равнин террасы аккумулятивные, в горных долинах чаще скульптурные. Поверхность их почти горизонтальная, изобилует заболоченными впадинами и прорезана современными долинами.

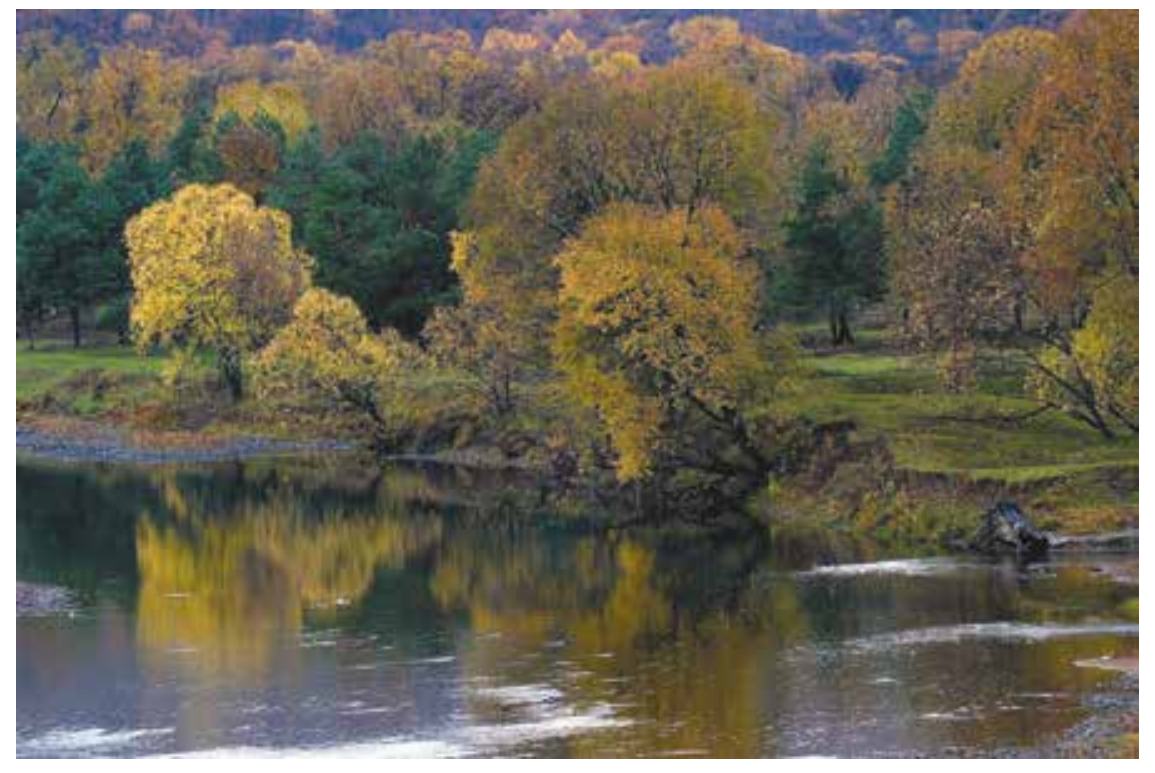

Puc. 32. Общий вид долинно-речного ландшафта Уссури-Ханкайской равнины. Фото О. Кабалика

Террасы верхнечетвертичного возраста имеют значительное распространение в приозерной части Уссури-Ханкайской равнины. В низовьях рек терраса обычно аккумулятивная, высотой 4-8 м. Поверхность ее покрыта заболоченными старичными понижениями и валами («релками») относительной высотой до 2-6 м. В пределах равнинного типа ландшафтов Уссури-Ханкайской равнины терраса имеет озерное происхождение. Наибольшая ширина ее в междуречье Сунгач - Белая до 15 км, абс. высота 69-74 м, относительное превышение 4-6 м. Развиты заболоченные понижения продолговатой или округлой формы. В катастрофические наводнения террасы подвергаются затоплению.

Современные террасы эрозионно-аккумулятивного происхождения в регионе подразделяются на озерные и речные. Озерные террасы развиты на восточном и южном берегах оз. Ханка и у крупных озер на морском побережье.

Наибольшая ширина современной террасы оз. Ханка зафиксирована между устьем р. Спассовка и истоком р. Сунгач, где она составляет 10-15 км. Уступ четкий, высотой 1-1,5 м. В тыловом шве относительная высота террасы относительно уровня озера до 4-5 м. От берега озера терраса обычно отделена песчаным 
валом шириной до 150 м и высотой до 3 м. Поверхность ее часто морфологически трудноотличима от высокой поймы низовьев рек, впадающих в оз. Ханка. Вместе они образуют широкую низменность, поверхность которой покрыта кочкарными болотами и изобилует мелкими озерами.

Современные террасы озер на морском побережье развиты обычно только на берегах, противоположных косам, отделяющим озера от моря. Поверхности террас заболочены. Высота их у тылового шва до 2 м, к берегу она постепенно уменьшается, и террасы местами переходят в пляжи или плавни. Поверхности современных террас затапливаются в период интенсивных осадков или при нагонных ветрах.

Речные современные террасы в пределах Уссури-Ханкайской равнины занимают значительную часть дна речных долин. Высота их над меженным уровнем крупных рек до 3-3,5 м, на менее крупных - до 1,5-2 м. Поверхность террас покрыта кочкарными понижениями и релками (валами), подвергаются ежегодному полному или частичному затоплению в период летних или осенних муссонных дождей.

Пойма озер представлена плоской переувлажненной поверхностью с относительной высотой 0,5-1,0 м, не имеющей уступа. Она сформирована в результате аккумуляции в волноприбойной зоне песчано-глинистого материала с обилием органики и погребенными торфяниками. Наиболее обширные участки низкой озерной поймы формируются в заливах и дельтах рек. Пойма заливается как в речной паводок, так и при ветровых (нагонных) изменениях уровней озер. В оз. Ханка пойма на длительное время затапливается при периодических колебаниях уровня.

Озерные пляжи развиты по берегам всех крупных озер, где проявлено ветровое волнение. Ширина пляжей составляет первые метры, редко первые десятки метров. Исключение представляют пляжи оз. Ханка, ширина которых достигает 100 м. Пляжи оз. Ханка песчаные, реже илистые, пляжи других озер щебенчатые, каменистые, реже песчаные.

Приморско-равнинный род ландшафтов (рис. 33). Приморскоравнинные ландшафты развиты на площади 625,7 км² на выровненных низинных, устьевых частях рек, районов развития бухт, заливов в прибрежной полосе Приморья. Они включают низинные вейниковые, осоко-вейниковые и разнотравно-злаковые луга с низинными осоковыми болотами и остатками широколиственных лесов на задерновано-слоистых, задернованных иловато-

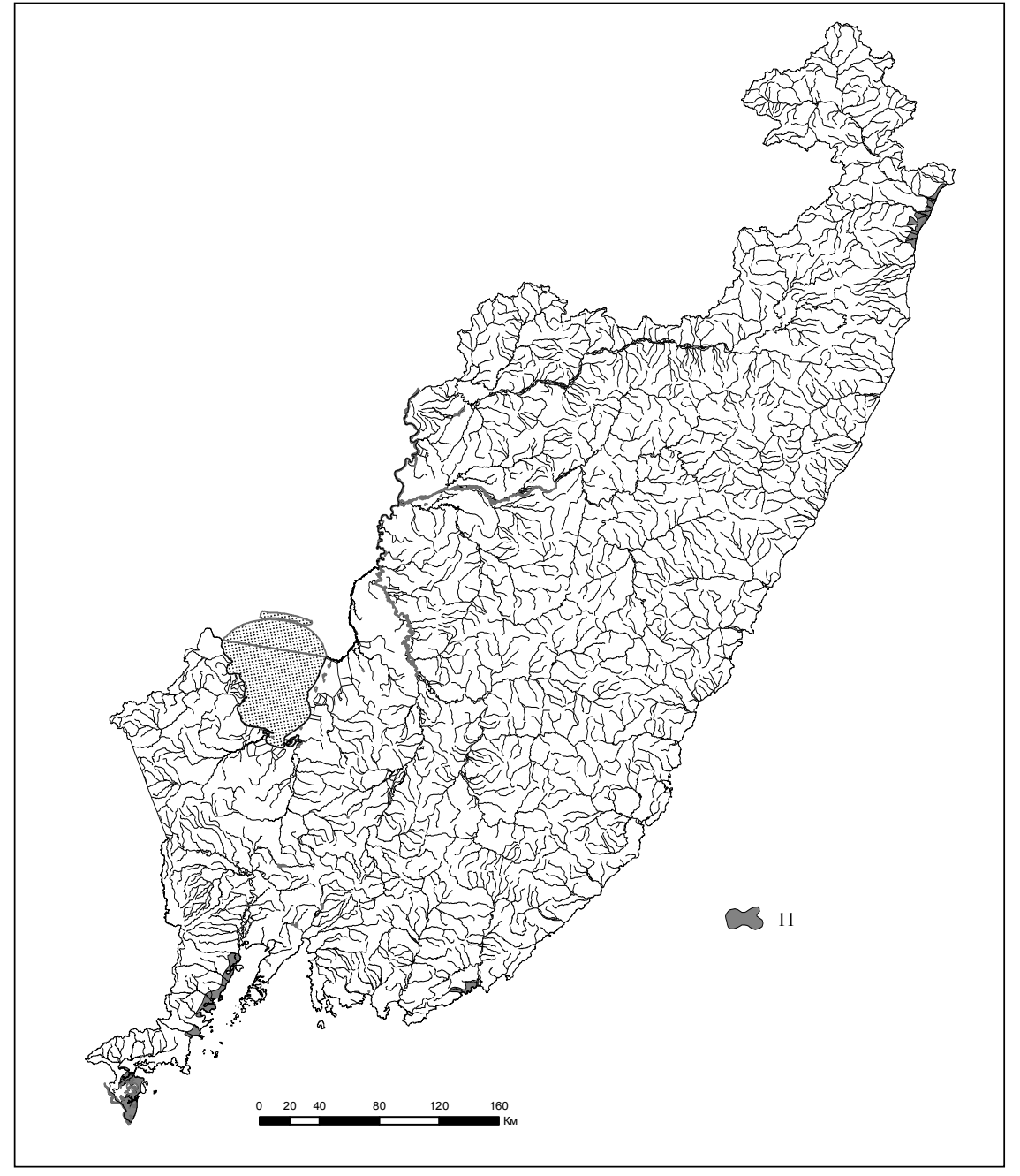

Рис. 33. Распространенность приморско-равнинных ландшафтов (11)

глеевых, дерново-перегнойных и дерново-торфянисто-глеевых, дерново-торфянистых и торфянисто-глеевых, дерново-пойменных и болотистых почвах. Распространены между устьм р. Тюмень-Ула и м. Фальшивый Островок, полуостровами Ломоносова и Песчаным, устьями рек Венюковка и Самарга. На таких участках расположены лагуны и реликтовые озера. В целом ландшафты Приморских равнин развиты на участках развития аккумулятивно 
выровненных морских берегов, характеризуются преобладанием химического выветривания фундамента, накоплением суглинистых и глинистых толщ, заилением водоемов, слабосдержанным и затруднительным водообменном.

\section{Контрольные вопросы}

1. Раскройте понятие подкласс ландшафтов.

2. Раскройте понятие род ландшафтов.

3. Охарактеризуйте горно-тундровый подкласс и гольцовый полисубстратный род ландшафтов.

4. Охарактеризуйте ландшафты горно-темнохвойного подкласса ландшафтов.

5. Дайте характеристику массивносреднегорного и расчлененносреднегорного полисубстратных родов ландшафтов (горно-темнохвойный подкласс).

6. Охарактеризуйте низкогорный вулканогенно-терригенный род ландшафтов (горно-темнохвойный подкласс).

7. Охарактеризуйте платобазальтовый род ландшафтов (горнотемнохвойный подкласс).

8. Охарактеризуйте горно-лесной смешанно-широколиственный подкласс ландшафтов.

9. Охарактеризуйте массивносреднегорный и расчлененносреднегорный полисубстратные роды ландшафтов (горно-лесной смешанно-широколиственный подкласс).

10. Охарактеризуйте низкогорный терригенный род ландшафтов (горно-лесной смешанно-широколиственный подкласс).

11. Охарактеризуйте мелкосопочный полисубстратный род ландшафтов (горно-лесной смешанно-широколиственный подкласс).

12. Охарактеризуйте платобазальтовый род ландшафтов (горнолесной смешанно-широколиственный подкласс).

13. Охарактеризуйте лесостепной равнинный и долинно-речной подкласс ландшафтов.

14. Охарактеризуйте равнинный эрозионно-аккумулятивный и долинно-речной род ландшафтов.

15. Охарактеризуйте приморско-равнинный род ландшафтов.

\section{Лекция 11}

\section{ОРГАНИЗАЦИЯ И ИЕРАРХИЧЕСКАЯ СТРУКТУРА ЛАНДШАФТОВ (видЫ, местности)}

\section{1 Виды ландшафтов}

Всем ходом физико-географического развития территории Приморского края предопределены не только формирование и эволюция описанных выше структур гольцового полисубстратного, массивносреднегорного и расчленено-среднегорного полисубстратных, низкогорного терригенного и вулканогеннотерригенного, мелкосопочникового полисубстратного и других родов ландшафтов, но и дифференциация территории по почвам и растительности (лекция 7). Поиск закономерностей в структуре и организации ландшафтов с учетом почвенно-растительного разнообразия дал возможность, с учетом дифференциации названных выше родов, подклассов ландшафтов, выявить и показать на картах определенное количество видов ландшафтов (94). Ниже, в качестве примера, приводится описание части видов ландшафтов, а полное описание их приведено в объяснительной записке к Карте ландшафтов Приморского края масштаба 1: 500000 [244]. Описание видов ландшафтов сделано с их привязкой к подклассам и родам (табл. 12). Названия видов даны по биотическому признаку, преимущественно по типу леса, но при создании крупномасштабных карт необходимо включение в название ландшафтных комплексов доминантных почв и форм рельефа. Это будет сделано при дальнейшей работе.

Лишайниково-кустарниковый вид ландшафтов (горно-тундровый пояс) включает горно-тундровые группировки растительности и почв, с лишайниково-кустарниковыми, травянистыми и стелющимися лесами на горно-тундровых иллювиально-гумусовых и дерново-органогенных почвах, имеет слабосдержанный водообмен, сформировался на территории гольцов и подгольцовых гор среднегорных районов Сихотэ-Алиня - 1 (1 - здесь и далее 


\section{Таблица 12}

Виды ландшафтов Приморского края (по родам, фрагмент)

\begin{tabular}{|c|c|}
\hline $\begin{array}{c}\text { Род } \\
\text { ландшафтов }\end{array}$ & $\begin{array}{c}\text { Вид ландшафтов (название дано } \\
\text { по преобладающему типу леса) }\end{array}$ \\
\hline $\begin{array}{l}\text { Гольцовый полисубстрат- } \\
\text { ный }\end{array}$ & Лишайниково-кустарниковый \\
\hline $\begin{array}{l}\text { Массивносреднегорный } \\
\text { полисубстратный } \\
\text { Расчлененносреднегор- } \\
\text { ный полисубстратный } \\
\text { Низкогорный вулкано- } \\
\text { генно-терригенный } \\
\text { Платобазальтовый }\end{array}$ & $\begin{array}{l}\text { Хвойнозеленомошный } \\
\text { Хвойнозеленомошный } \\
\text { Хвойнозеленомошный } \\
\text { Хвойно зеленомошный }\end{array}$ \\
\hline $\begin{array}{l}\text { Массивносреднегорный } \\
\text { полисубстратный }\end{array}$ & $\begin{array}{l}\text { Широколиственно-кедровый } \\
\text { Широколиственно-кедрово-еловый } \\
\text { Черно-пихтово-широколиственный } \\
\text { Грабово-широколиственный } \\
\text { Широколиственный } \\
\text { Лиственнично-хвойно-смешанный } \\
\text { Дубовый } \\
\text { Мелколиственный по гарям } \\
\text { Широколиственно-мелколиственный } \\
\text { Мелколиственный } \\
\text { Пихтово-елово-лиственнично-мелко- } \\
\text { лиственный } \\
\text { Невозобновившихся молодых гарей }\end{array}$ \\
\hline $\begin{array}{l}\text { Низкогорный терриген- } \\
\text { ный }\end{array}$ & $\begin{array}{l}\text { Широколиственно-кедровый } \\
\text { Широколиственно-кедрово-еловый } \\
\text { Грабово-черно-пихтово-широколист- } \\
\text { венный } \\
\text { Грабово-широколиственный } \\
\text { Широколиственный с порослевыми } \\
\text { зарослями } \\
\text { Широколиственный с липами, кленом } \\
\text { и дубом. } \\
\text { Лиственнично-хвойно-смешанный } \\
\text { Дубовый } \\
\text { Остепненный дубово-березово-разно- } \\
\text { травный } \\
\text { Широколиственно-мелколиственный } \\
\text { Дубовый порослево-кустарниково-за- } \\
\text { рослевый } \\
\text { Мелколиственный }\end{array}$ \\
\hline
\end{tabular}

по тексту и на Картах ландшафтов Приморского края масштабов 1: 500000 и 1: 1000000 номер вида ландшафта [243]). Занимает площадь около 608 кв. км, или 0,4\% площади края (рис. 34, 35).

Вид ландшафтов хвойнозеленомошных лесов (массивно-среднегорный полисубстратный род, горно-темнохвойный пояс) включает пихтово-еловые леса на горно-таежных бурых иллювиально-гумусовых почвах, имеет слабосдержанный водообмен, сформировался на наиболее возвышенных куполовидных массивах Сихотэ-Алиня (2). Занимает площадь 3960,5 кв. км, или 2,4\% площади края.

Хвойнозеленомошный вид сформировался в среднегорных районах Сихотэ-Алиня (3). Входит в расчленено-среднегорный полисубстратный род, горно-темнохвойный пояс и включает (рис. 36) пихтово-еловые леса на горно-таежных бурых иллювиально-гумусовых почвах. Имеет быстрый водообмен, обеспечивающий активные биогеохимические процессы. Занимает площадь 12047,5 кв. км, или 7,5\% площади края.

Видландшафтов хвойно-зеленомошных лесов (платобазальтовый род, горно- темнохвойный пояс) пихтово-еловые леса на горно-

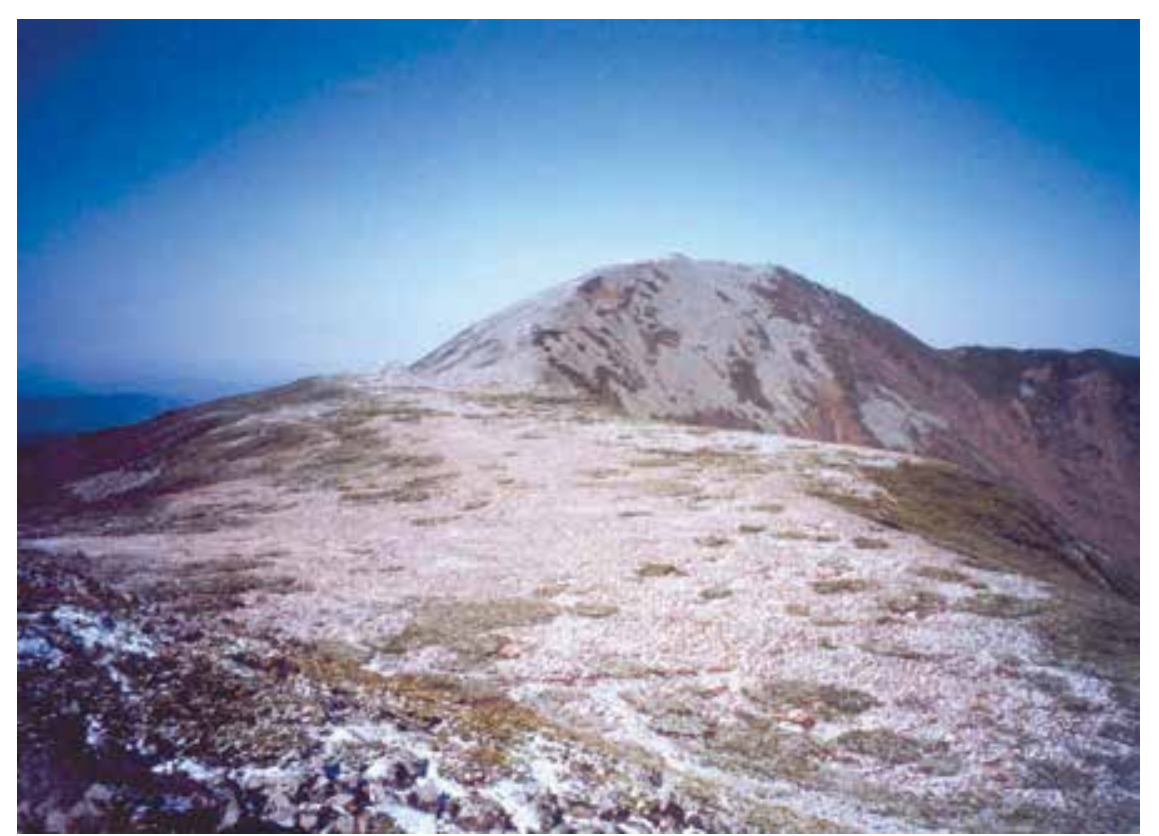

Puc. 34. Горно-тундровый лишайниково-кустарниковый вид ландшафта. Фото Г. Шаликова 


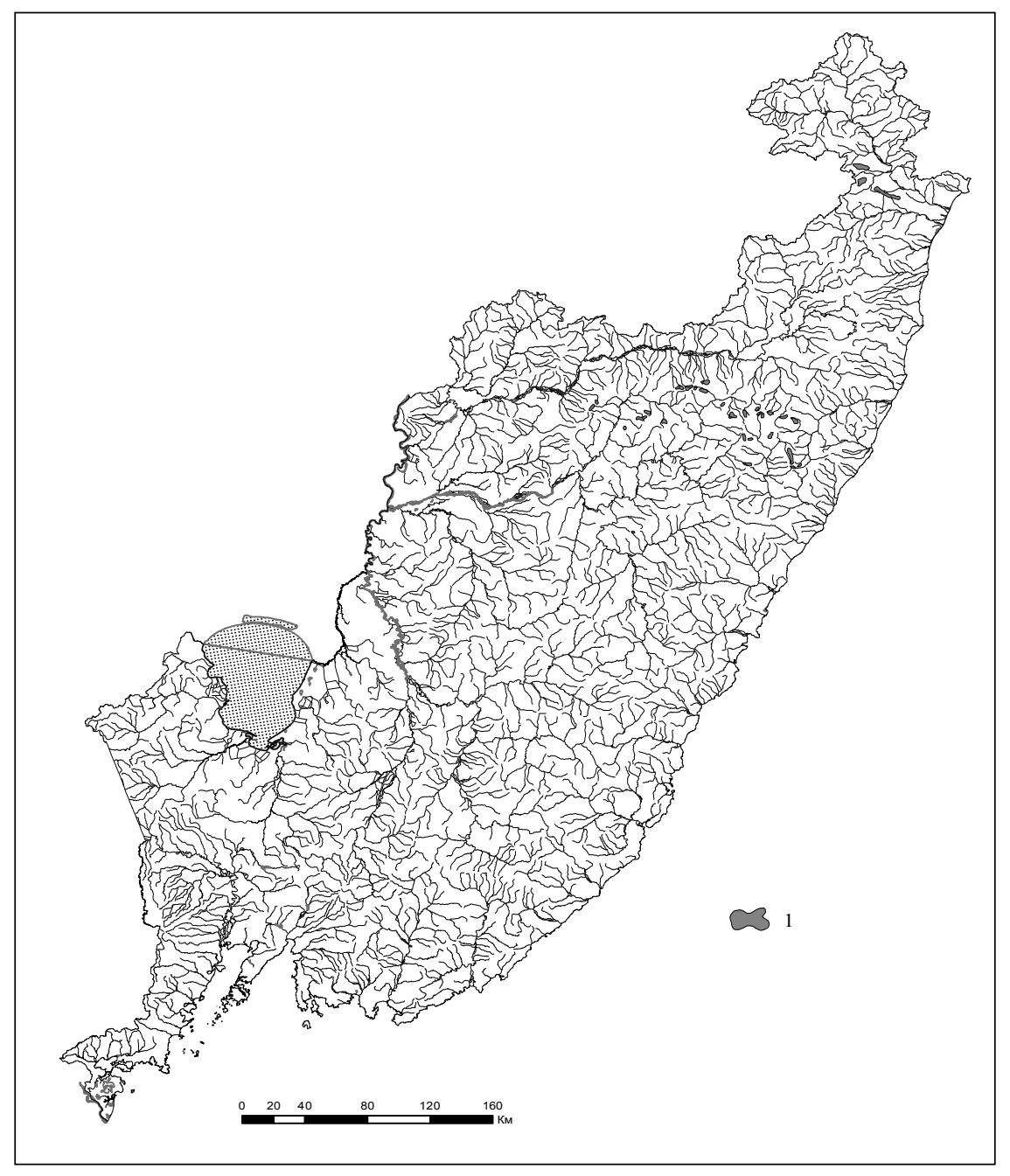

Рис. 35. Распространенность горно-тундровых лишайниковокустарниковых ландшафтов горно-тундрового пояса (1)

таежных бурых, охристо-бурых неоподзоленных и глеевато-оподзоленных, глеевых почвах, имеет затрудненный водообмен (5). Занимает площадь 2580 кв. км, или 1,6\% площади края (рис. 37).

Вид ландшафтов широколиственно-кедровых лесов (массивносреднегорный полисубстратный род, горно-лесной смешанношироколиственный пояс) включает широколиственно-кедровые

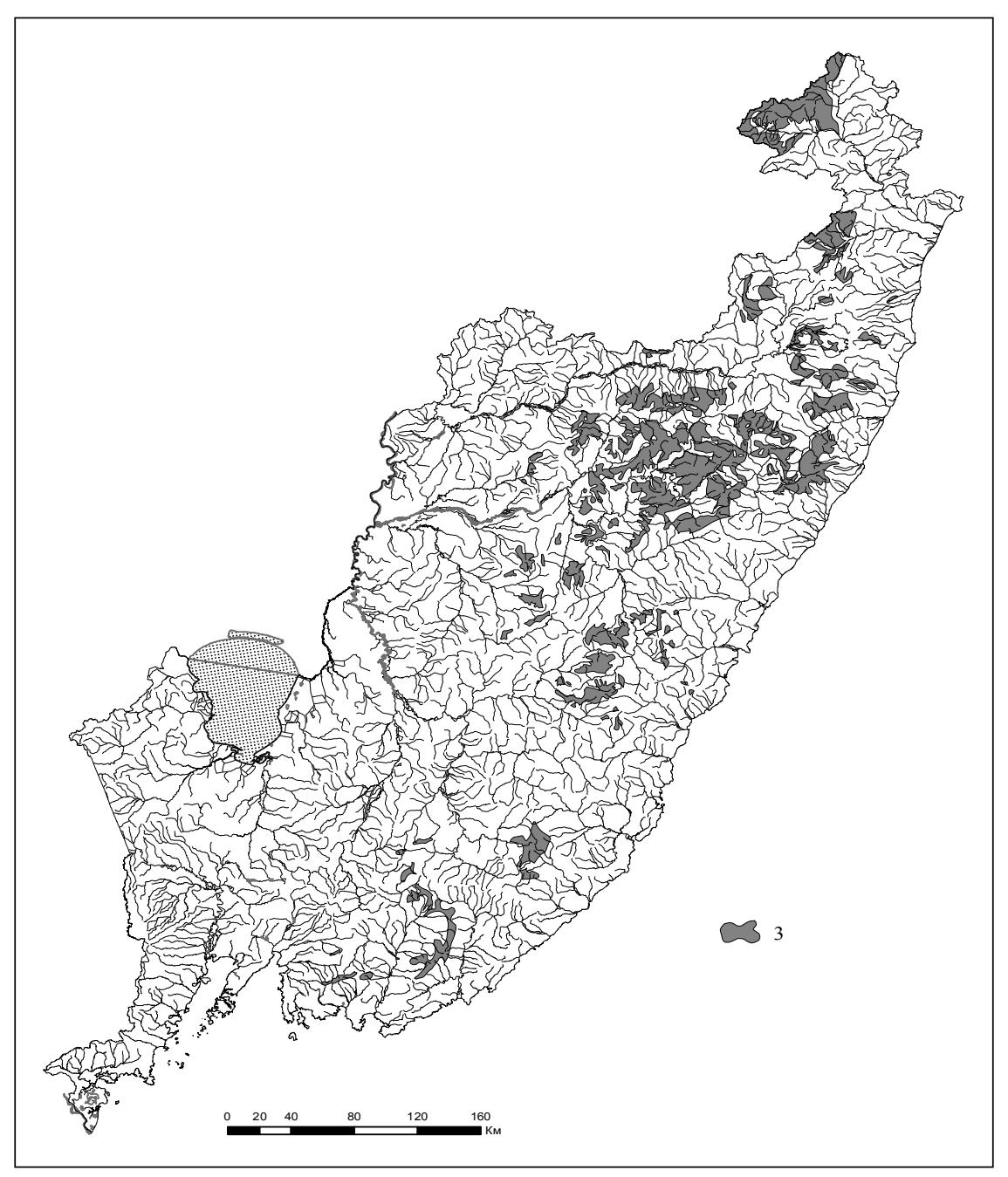

Рис. 36. Распространенность расчленено-среднегорных хвойнозеленомошных лесных ландшафтов горно-темнохвойного пояса (3)

и кедровые леса на горно-лесных бурых, слабокислых, оподзоленных и неоподзоленных почвах, имеет слабосдержанный водообмен (6) (рис. 38). Занимает площадь 2005,3 кв. км, или 1, $25 \%$ площади края.

Вид ландшафтов широколиственно-кедрово-еловых лесов (массивно-среднегорный полисубстратный род, горно-лесной смешан- 


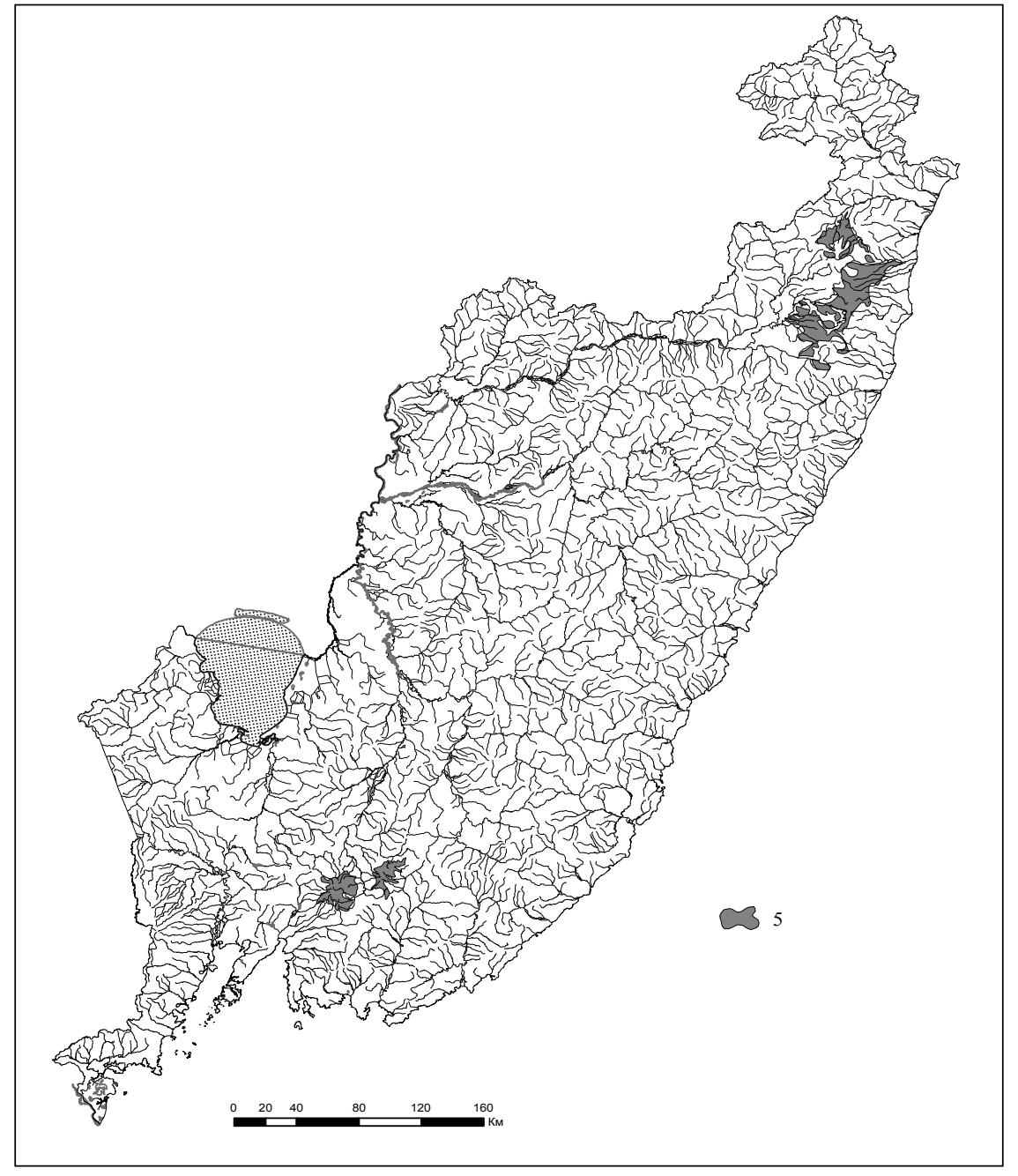

Рис. 37. Распространенность платобазальтовых хвойно-зеленомошных лесных ландшафтов горно-темнохвойного пояса (5)

но-широколиственный пояс) включает широколиственно-кедровые и кедрово-еловые леса на горно-лесных бурых кислых неоподзоленных и оподзоленных почвах, имеет слабосдержанный водообмен (7). Занимает площадь 4138 кв. км, или 2,6\% площади края.

Вид ландшафтов грабовых черно-пихтово-широколиственных лесов (массивно-среднегорный полисубстратный род, горно-лесной смешанно-широколиственный пояс) включает грабовые широко-

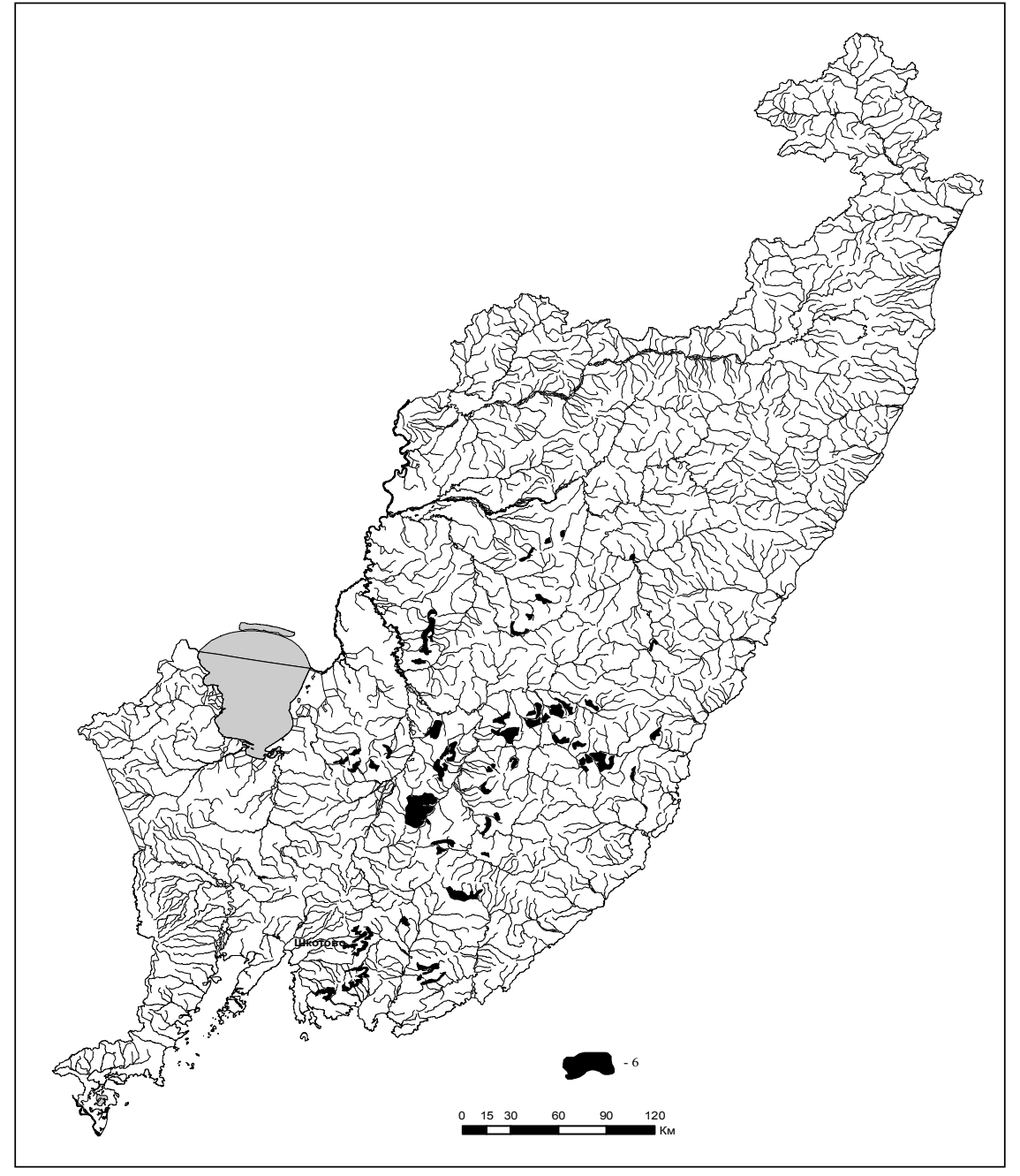

Puc. 38. Распространенность массивно-среднегорных

широколиственно-кедровых ландшафтов горно-лесного смешанношироколиственного пояса (6)

лиственно-кедровые леса с цельнолистной (черной) пихтой и чернопихтово-широколиственными лесами на горно-лесных-бурых слабокислых неоподзоленных и оподзоленных, горно-лесных бурых кислых и лесных бурых глеевато - и глеевоотбеленных почвах, имеет слабосдержанный водообмен (8). Занимает площадь 315 кв. км, или 0,2\% площади края. 
Вид ландшафтов грабово-широколиственных лесов (массивносредне-горный полисубстратный род, горно-лесной смешанношироколиственный пояс) включает грабовые широколиственные леса с липами, кленом и дубом монгольским, их редколесьями и порослевыми зарослями на горно-лесных бурых кислых, желто-бурых, бурых слабокислых неоподзоленных и оподзоленных почвах, имеет слабосдержанный водообмен (9). Занимает площадь 321 кв. км, или 0,2\% площади края.

Вид ландшафтов широколиственных лесов (массивно-среднегорный полисубстратный род, горно-лесной смешанно-широколиственный пояс) включает широколиственные леса с липами, кленом мелколистным, дубом монгольским, их редколесья и порослевые заросли на горно-лесных бурых слабокислых неоподзоленных и оподзоленных, бурых глеевато-отбеленных, бурых лесных слабокислых и реже горно-лесных бурых кислых грубоскелетных почвах, имеет слабосдержанный водообмен (10). Занимает площадь 94 кв. км, или 0,06\% площади края.

Вид ландшафтов лиственнично-хвойно-смешанных лесов (массивно-среднегорный полисубстратный род, горно-лесной смешанно-широколиственный пояс) включает лиственничные леса горных заболоченных широких долин рек и межгорных котловин в комплексе с участками хвойных и смешанных лесов на горно-таежных бурых иллювиально-гумусовых оподзоленных и неоподзоленных, подзолистых и иллювиально-гумусовых, горно-таежных охристо-бурых неоподзоленных и оподзоленных, реже глеевато-оподзоленных и глеевых почвах, имеет слабосдержанный водообмен (11). Занимает площадь 152 кв. км, или 0,09\% площади края.

Вид ландшафтов дубовых лесов (массивно-среднегорный полисубстратный род, горно-лесной смешанно-широколиственный пояс) включает дубовые леса из дуба монгольского, их редколесья и порослевые заросли на горно-лесных бурых слабокислых неоподзоленных и оподзоленных, горно-лесных, бурых кислых грубоскелетных почвах, имеют слабосдержанный водообмен (12). Занимает площадь 134 кв. км, или 0,08\% площади края.

Вид ландшафтов мелколиственных лесов (массивно-среднегорный полисубстратный род, горно-лесной смешанно-широколиственный пояс) включает мелколиственные леса (береза, осина) на горно-таежных бурых иллювиально-гумусовых неоподзоленных и оподзоленных, охристо-бурых глеевато- оподзоленных и глееватых, подзолистых иллювиально-гумусовых, горно-лесных бурых кислых, желто-бурых и дерново-бурых, редко грубоскелетных почвах, имеет слабосдержанный водообмен (13). Занимает площадь 445 кв. км, или 0,28\% площади края.

Вид ландшафтов широколиственно-мелколиственных лесов (массивно-среднегорный полисубстратный род, горно-лесной смешанно-широколиственный пояс) включает мелколиственные леса (береза, осина) в комплексе с участками широколиственных лесов (дуб, липа, ясень) на горно-таежных бурых иллювиально-гумусовых, неоподзоленных горно-лесных бурых кислых грубоскелетных почвах, имеет слабосдержанный водообмен (14, рис. 39) Занимает 333 кв. км, или 0,21\% площади края.

Вид ландшафтов пихтово-елово-лиственично-мелколиственных лесов_(массивно-среднегорный полисубстратный род, горнолесной смешанно-широколиственный пояс) включает комплекс пихтово-еловых, лиственничных, елово-лиственничных и мелколиственных лесов (местами с широколиственными породами) на горно-таежных бурых, иллювиально-гумусовых оподзоленных и неоподзоленных, подзолистых, охристо-бурых, глеевато-оподзоленных почвах, имеет слабосдержанный водообмен (16). Занимает 417 кв. км, или 0,26\% площади края.

Вид ландшафтов широколиственно-кедровых лесов (расчленено-среднегорный полисубстратный род, горно-лесной смешанно-широколист-венный пояс) (18, рис. 40, 41) включает широколиственно-кедровые и кедровые леса на горно-лесных бурых, слабокислых, оподзоленных и неоподзоленных почвах, имеет быстрый водообмен. Занимает площадь 5577 кв. км, или 3,5\% площади края.

Вид ландшафтов широколиственно-кедрово-еловых лесов (расчленено-среднегорный полисубстратный род, горно-лесной смешанно-широколиственный пояс) (19) включает широколиственно-кедровые и кедрово-еловые леса на горно-лесных бурых кислых неоподзоленных и оподзоленных почвах, имеет быстрый водообмен (рис. 42). Занимает площадь 7598 кв. км, или 4,7\% площади края.

Вид ландшафтов грабовых черно-пихтово-широколиственных лесов (расчленено-среднегорный полисубстратный род, горнолесной смешанно-широколиственный пояс) (20) включает грабовые широколиственно-кедровые леса с цельнолистной (черной) пихтой и черно-пихтово-широколиственными лесами на горнолесных-бурых слабокислых неоподзоленных и оподзоленных, горно-лесных бурых кислых и лесных бурых глеевато-, и глеево- 


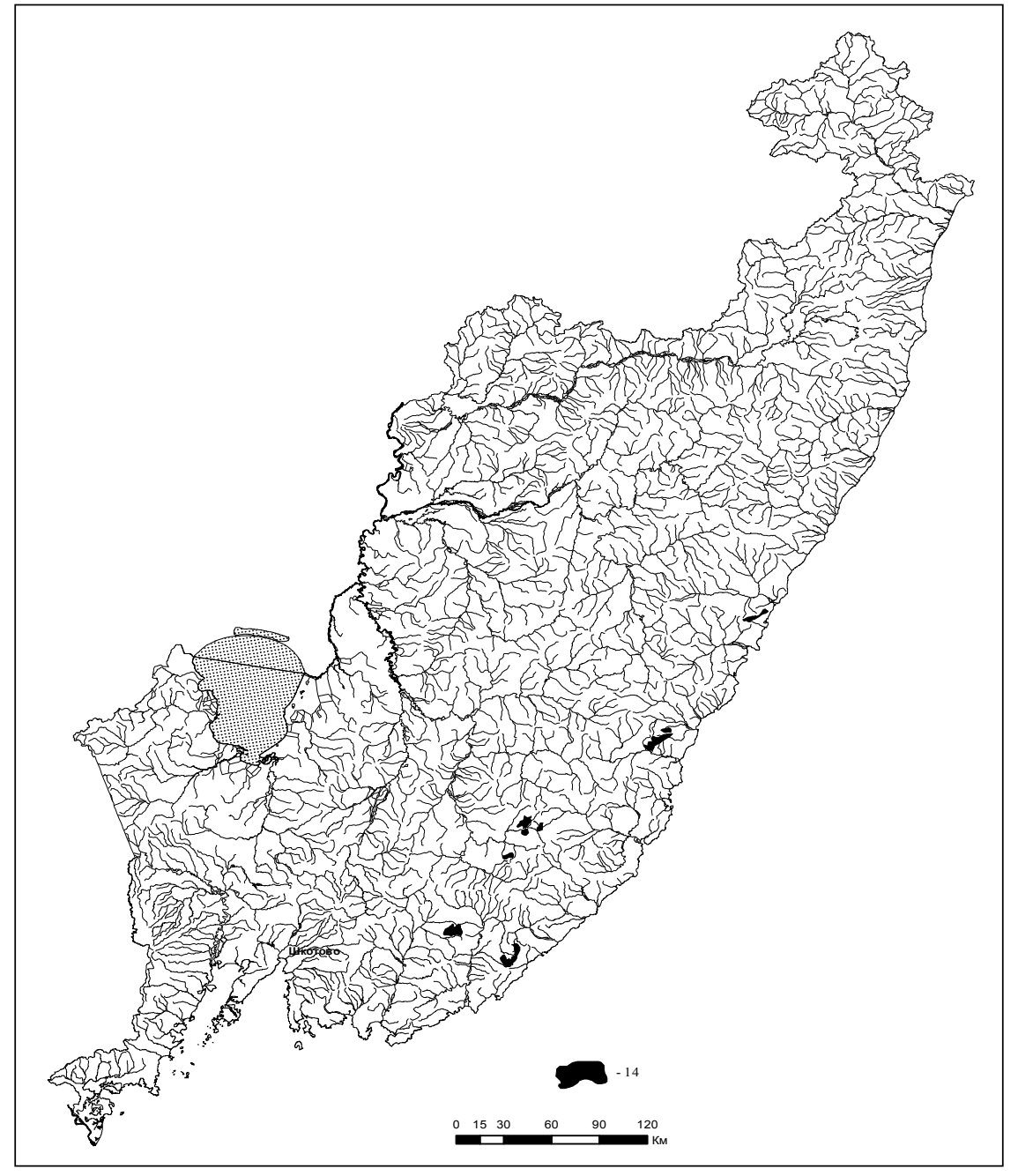

Puc. 39. Распространенность массивно-среднегорных лесных ландшафтов широколиственно-мелколиственных лесов горно-лесного смешанно-широколиственного пояса (14)

отбеленных почвах, имеет быстрый водообмен. Занимает площадь 21 кв. км, или менее 0,01\% площади края.

Вид ландшафтов грабово-широколиственных лесов (расчлененосреднегорный полисубстратный род, горно-лесной смешанно-широколист-венный пояс) (21) включает грабовые широколиственные леса с липами, кленом и дубом монгольским, их редколесья

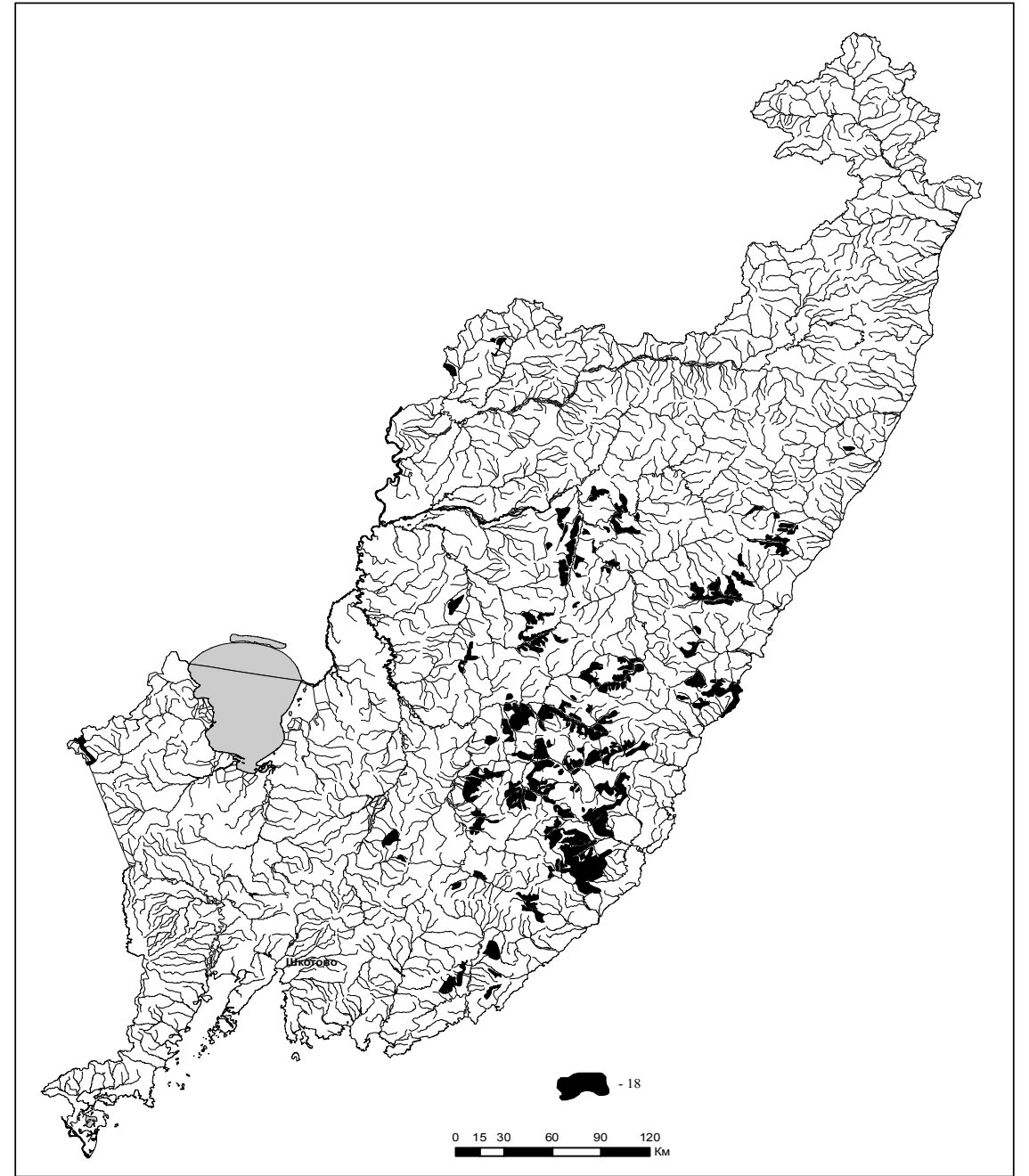

Рис. 40. Распространенность расчленено-среднегорных лесных широколиственно-кедровых ландшафтов горно-лесного смешанношироколиственного пояса (18)

и порослевые заросли на горно-лесных бурых кислых, желто-бурых, бурых слабокислых неоподзоленных и оподзоленных почвах, имеет быстрый водообмен. Занимает площадь 109 кв. км, или 0,07\% площади края.

Вид ландшафтов широколиственных лесов (22, рис. 43) (расчленено-среднегорный полисубстратный род, горно-лесной сме- 


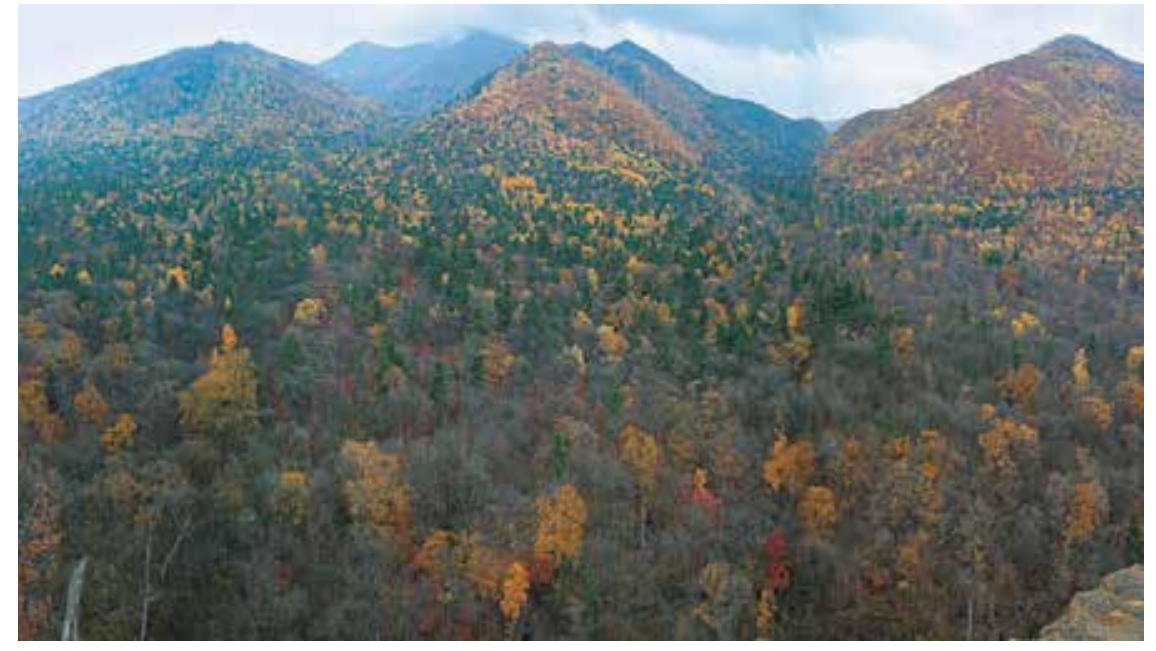

Puc. 41. Общий вид широколиственно-кедровых лесов Сихотэ-Алиня [7]

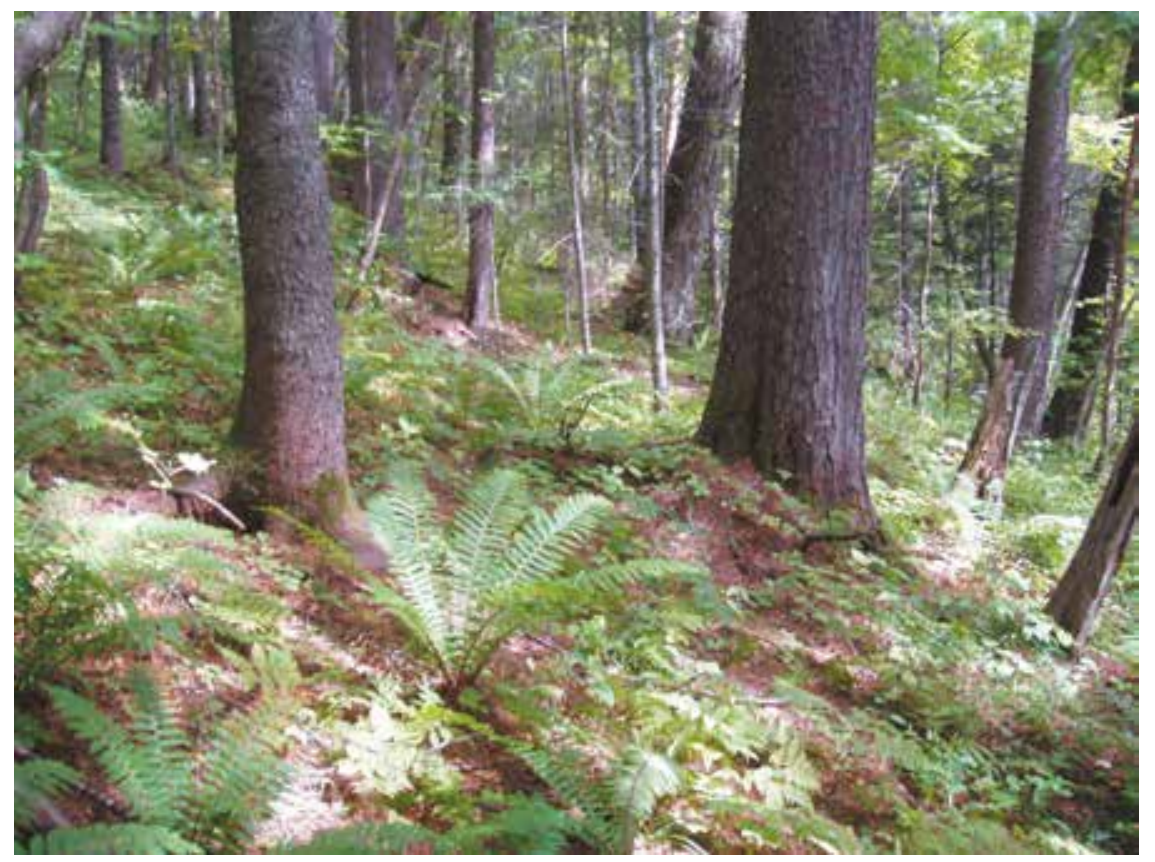

Puc. 42. Общий вид фрагмента ландшафта с кедрово-еловым лесом [7]

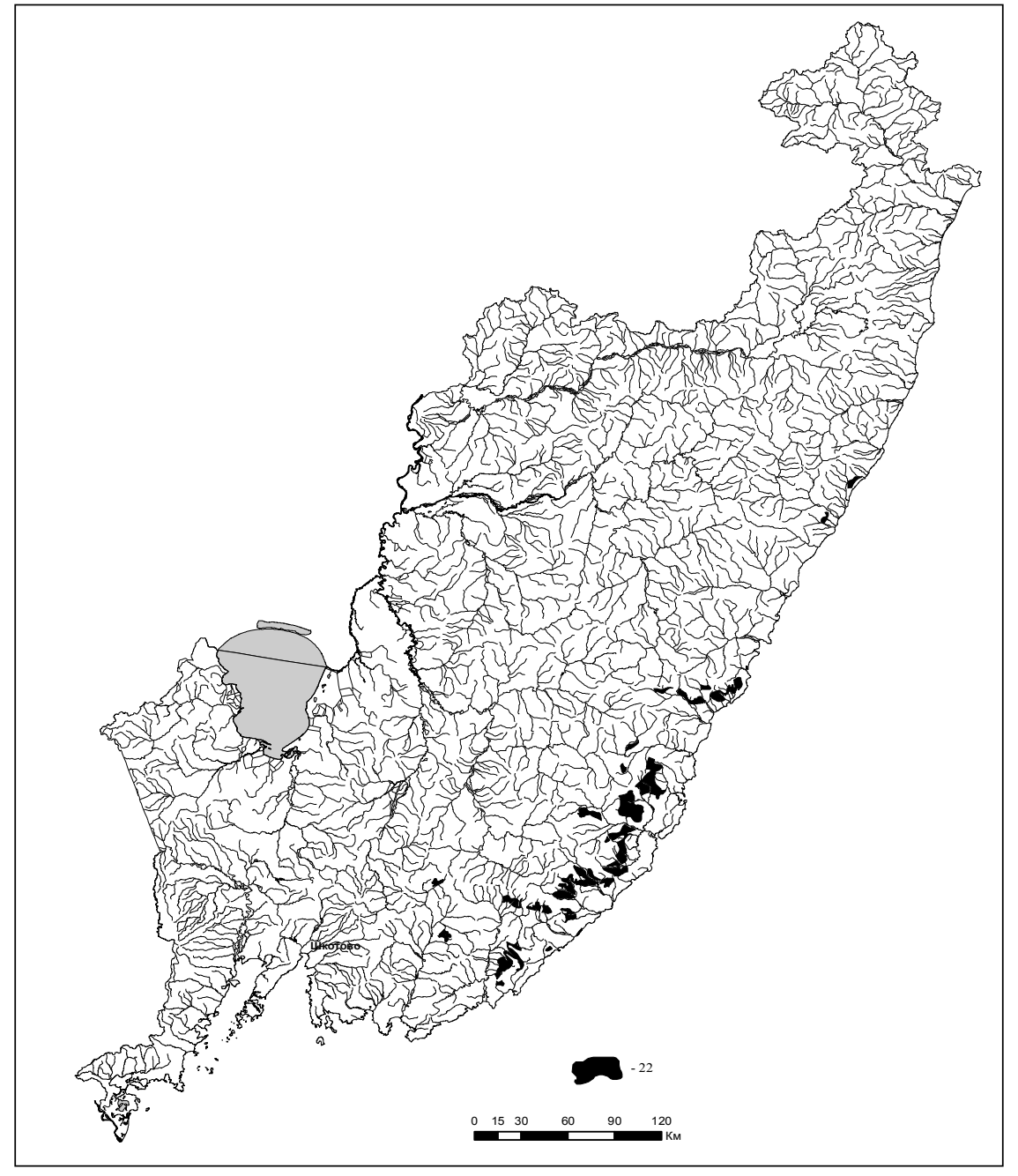

Рис. 43. Распространенность расчленно-среднегорных широколиственных лесов

шанно-широколиственный пояс) включает широколиственные леса с липами, лесных ландшафтов горно-лесного смешанношироколиственного пояса (22) кленом мелколистным, дубом монгольским, их редколесьями и порослевыми зарослями на горно-лесных бурых слабокислых неоподзоленных и оподзоленных, бурых глеевато-отбеленных, бурых лесных слабокислых и, реже, горно-лесных бурых кислых грубоскелетных почвах, имеет 
быстрый водообмен. Занимает он площадь 1586 кв. км, или 1 , $0 \%$ площади края.

Вид ландшафтов лиственично-хвойно-смешанных лесов (расчленено-среднегорный полисубстратный род, горно-лесной смешанно-широколиственный пояс) (23) включает лиственничные леса горных заболоченных широких долин рек и межгорных котловин в комплексе с участками хвойных и смешанных лесов на горнотаежных бурых иллювиально-гумусовых оподзоленных и неоподзоленных, подзолистых и иллювиально-гумусовых, горно-таежных охристо-бурых неоподзоленных и оподзоленных, реже глеевато-оподзоленных и глеевых почвах, имеет быстрый водообмен. Занимает площадь 1130 кв. км, или $0,7 \%$ площади края.

Мелколиственный по гарям вид ландшафтов (расчлененосреднегорный полисубстратный род, горно-лесной смешанношироколиственный пояс) (24) включает дубовые леса из дуба монгольского, их редколесьями и порослевыми зарослями на горно-лесных бурых слабокислых неоподзоленных и оподзоленных, горно-лесных, бурых кислых грубоскелетных почвах, имеет быстрый водообмен. Занимает площадь 2396 кв. км, или 1,5\% площади края.

Мелколиственный по гарям вид ландшафтов (расчлененосреднегорный полисубстратный род, горно-лесной смешанношироколиственный пояс) (25) является аналогом предыдущего и включает мелколиственные леса (береза, осина) по гарям на горно-таежных бурых иллювиально-гумусовых неоподзоленных и оподзоленных, охристо-бурых глеевато- оподзоленных и глееватых, подзолистых иллювиально-гумусовых, горно-лесных бурых кислых, желто-бурых и дерново-бурых, редко грубоскелетных, почвах, имеет быстрый водообмен. Занимает площадь 3108 кв. км, или $1,9 \%$ площади края

Виды ландшафтов 24 и 25 близки и при дальнейших исследованиях в будущем возможно их объединение.

Вид ландшафтов широколиственно-мелколиственных лесов (расчленено-среднегорный полисубстратный род, горно-лесной смешанно-широколиственный пояс) (26) включает мелколиственные леса (береза, осина) в комплексе с участками широколиственных лесов (дуб, липа, ясень) на горно-лесных бурых кислых, желтобурых и дерново-бурых, горно-таежных бурых, иллювиально-гумусовых оподзоленных и неоподзоленных, подзолистых, иллювиально-гумусовых, горно-лесных бурых кислых и лесных-бурых глеевато- и глеево-отбеленных, лесных бурых кислых почвах, имеет быстрый водообмен. Занимает 1475 кв. км, или 0,9\% площади края.

Вид ландшафтов пихтово-елово-лиственнично-мелколиственных лесов (расчленено-среднегорный полисубстратный род, горно-лесной смешанно-широколиственный пояс) (27) включает комплекс пихтово-еловых, лиственничных, елово-лиственничных и мелколиственных лесов (местами с широколиственными породами) на горно-таежных бурых, иллювиально-гумусовых оподзоленных и неоподзоленных, подзолистых, охристо-бурых, глеевато-оподзоленных почвах, имеет быстрый водообмен. Занимает 5048 кв. км, или $3,1 \%$ площади края.

Вид ландшафтов широколиственно-кедровых лесов (низкогорный терригенный род, горно-лесной смешанно-широколиственный пояс) $(29$, рис. 44,45$)$ включает широколиственно-кедровые и кедровые леса на горно-лесных бурых, слабокислых, оподзоленных и неоподзоленных почвах, имеет быстрый водообмен на узких водоразделах и крутых склонах, слабосдержанный на широких водоразделах и выположенных склонах. Занимает площадь 14507 кв. км, или $9 \%$ площади края.

Вид ландшафтов широколиственно-кедрово-еловых лесов (30) (низкогорный терригенный род, горно-лесной смешанно-широколиственный пояс) (рис. 46) включает широколиственно-кедровые и кедрово-еловые леса на горно-лесных бурых кислых неоподзоленных и оподзоленных почвах, имеет быстрый водообмен на узких водоразделах и крутых склонах, слабосдержанный на широких водоразделах и выположенных склонах. Занимает площадь 7404 кв. км, или 4,6\% площади края.

Вид ландшафтов грабовых черно-пихтово-широколиственных лесов (низкогорный терригенный род, горно-лесной смешанношироколиственный пояс) (31) включает грабовые широколиственно-кедровые леса с цельнолистной (черной) пихтой и чернопихтово-широко-лиственными лесами на горно-лесных-бурых слабокислых неоподзоленных и оподзоленных, горно-лесных бурых кислых и лесных бурых глеевато - и глеевоотбеленных почвах, имеет быстрый водообмен на узких водоразделах и крутых склонах, слабосдержанный на широких водоразделах и выположенных склонах Занимает площадь 562 кв. км, или 0,4\% площади края.

Вид ландшафтов грабово-широколиственных лесов (низкогорный терригенный род, горно-лесной смешанно-широколиственный пояс) (32, рис. 47) включает грабовые широколиственные леса 


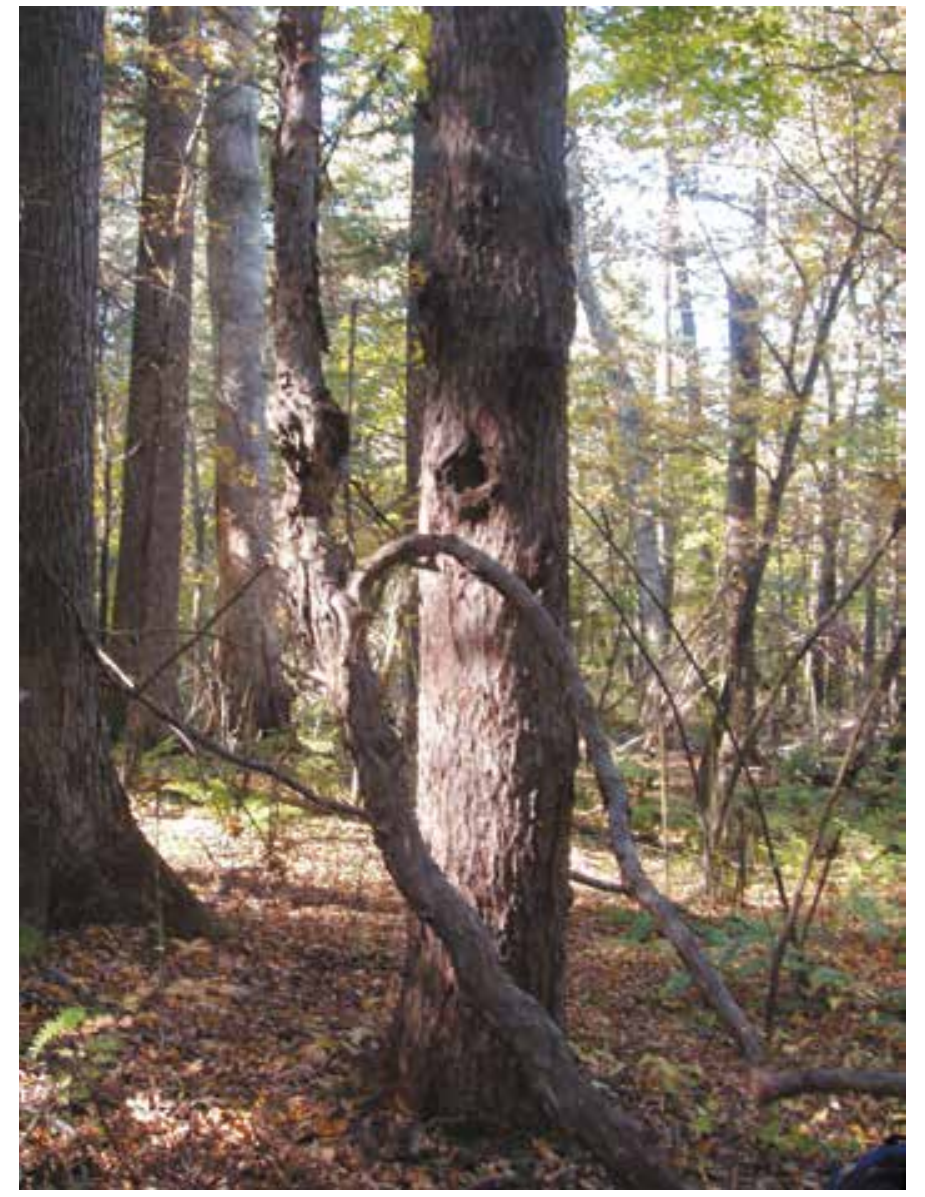

Puc. 44. Общий вид фрагмента ландшафта с широколиственно-

$$
\text { кедровым лесом [7] }
$$

с липами, кленом и дубом монгольским, их редколесья и порослевые заросли на горно-лесных бурых кислых, желто-бурых, бурых слабокислых неоподзоленных и оподзоленных почвах, имеет быстрый водообмен на узких водоразделах и крутых склонах, слабосдержанный на широких водоразделах и выположенных склонах. Занимает площадь 2692 кв. км, или 1,7\% площади края.

Вид ландшафтов широколиственных лесов с порослевыми зарослями (низкогорный терригенный род, горно-лесной смешанно-широколиственный пояс) (33) включает широколиственные леса и порослевые заросли с ясенем маньчжурским, березой

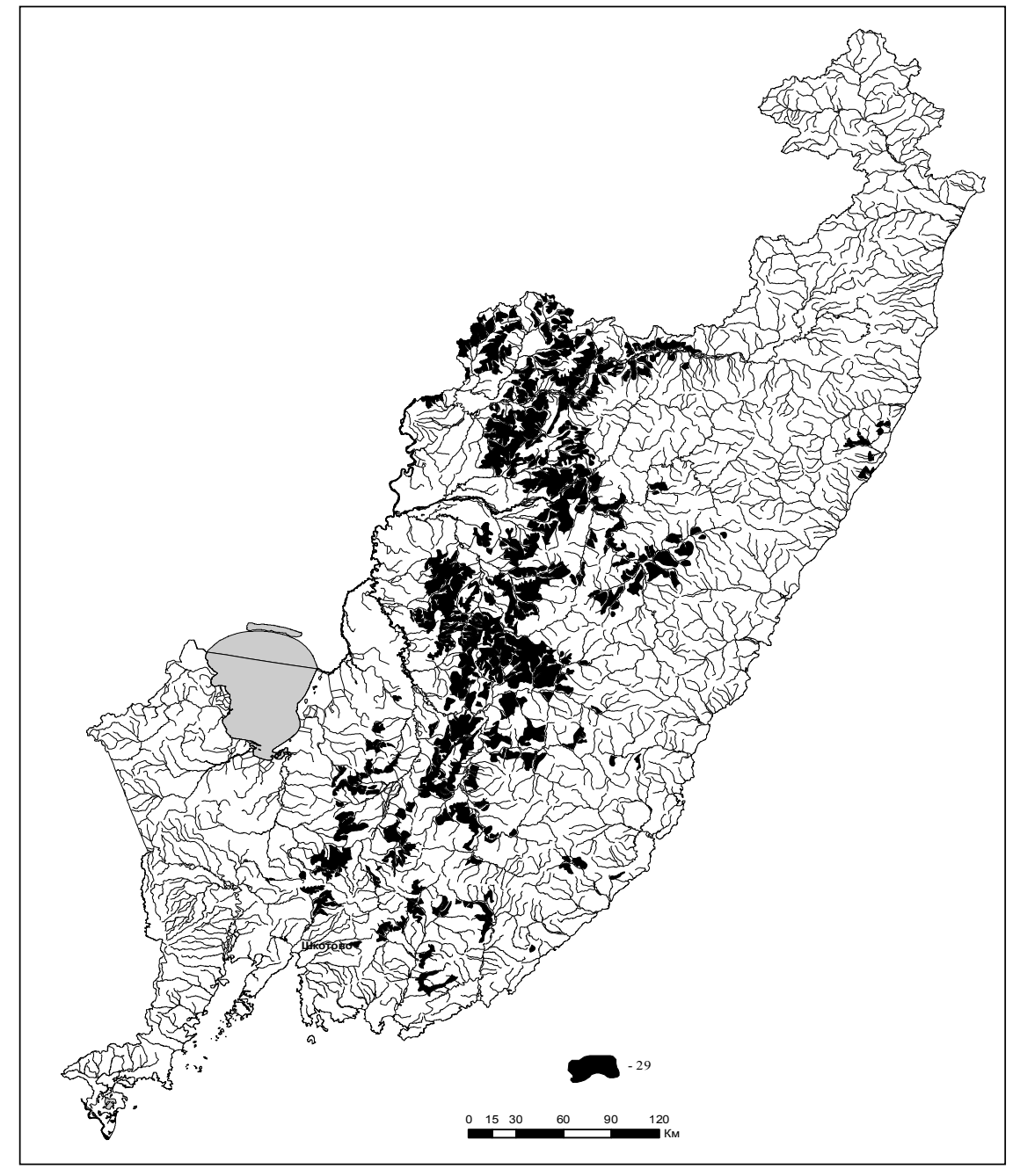

Рис. 45. Распространенность низкогорных широколиственно-кедровых лесных ландшафтов горно-лесного смешанно-широколиственного пояса (29)

маньчжурской, осиной в комплексе с участками мелколистных и смешанных лесов на бурых глеевато-отбеленных бурых лесных слабокислых почвах, имеет быстрый водообмен на узких водоразделах и крутых склонах, слабосдержанный на широких водоразделах и выположенных склонах. Занимает площадь 388 кв. км, или $0,2 \%$ площади края. 


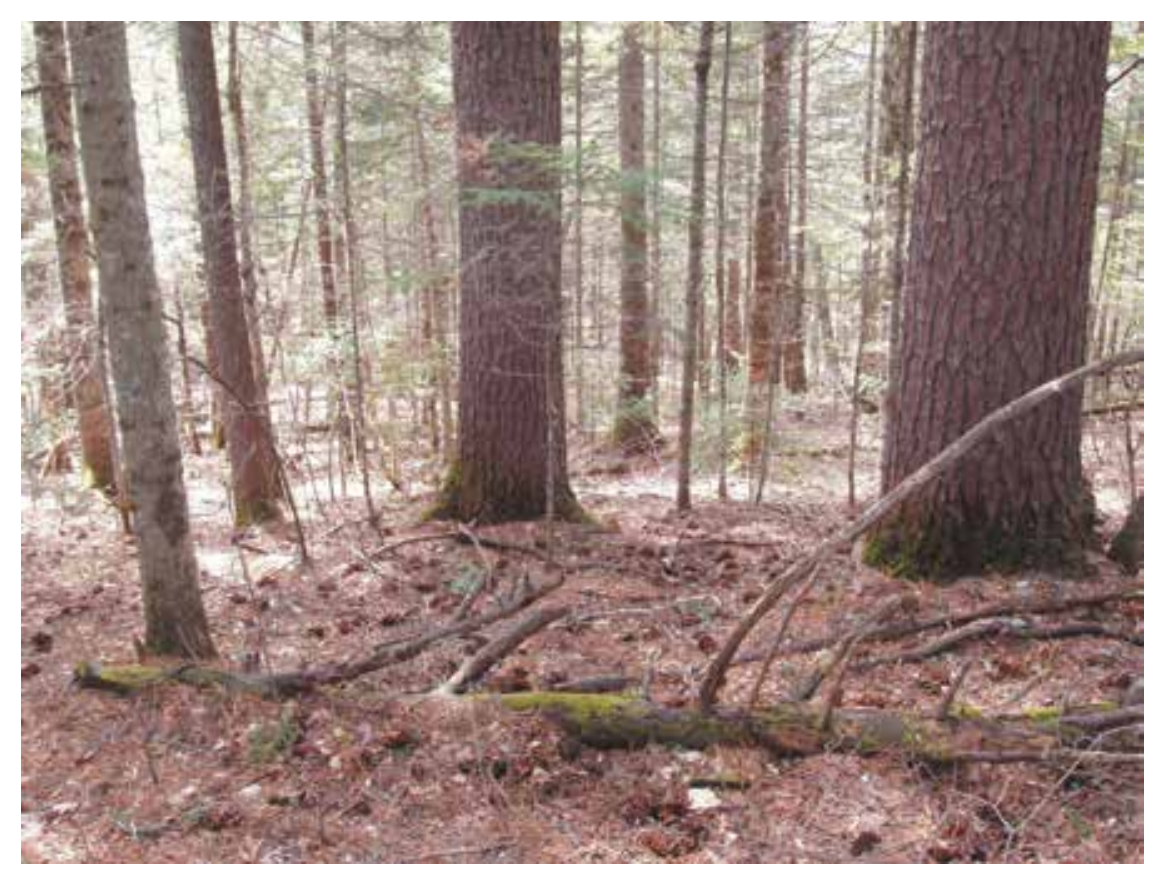

Puc. 46. Общий вид ландшафта с кедрово-еловыми лесами [7]

Вид ландшафтов широколиственных лесов с липами, кленом u дубом (низкогорный терригенный род, горно-лесной смешанно-широколиственный пояс) (34) включает широколиственные леса с липами, кленом мелколистным, дубом монгольским на горно-лесных бурых слабокислых неоподзоленных и оподзоленных, бурых глеевато-отбеленных, бурых лесных слабокислых и, реже, горно-лесных бурых кислых грубоскелетных почвах, имеет быстрый водообмен на узких водоразделах и крутых склонах, слабосдержанный на широких водоразделах и выположенных склонах. Занимает площадь 5167 кв. км, или 3,2\% площади края.

Вид ландшафтов лиственнично-хвойно-смешанных лесов (низкогорный терригенный род, горно-лесной смешанно-широколиственный пояс) (35) включает лиственничные леса горных заболоченных широких долин рек (рис. 48) и межгорных котловин в комплексе с участками хвойных и смешанных лесов на горнотаежных бурых иллювиально-гумусовых оподзоленных и неоподзоленных, подзолистых и иллювиально-гумусовых, горно-таежных охристо-бурых неоподзоленных и оподзоленных, реже глееватооподзоленных и глеевых почвах, имеет быстрый водообмен на

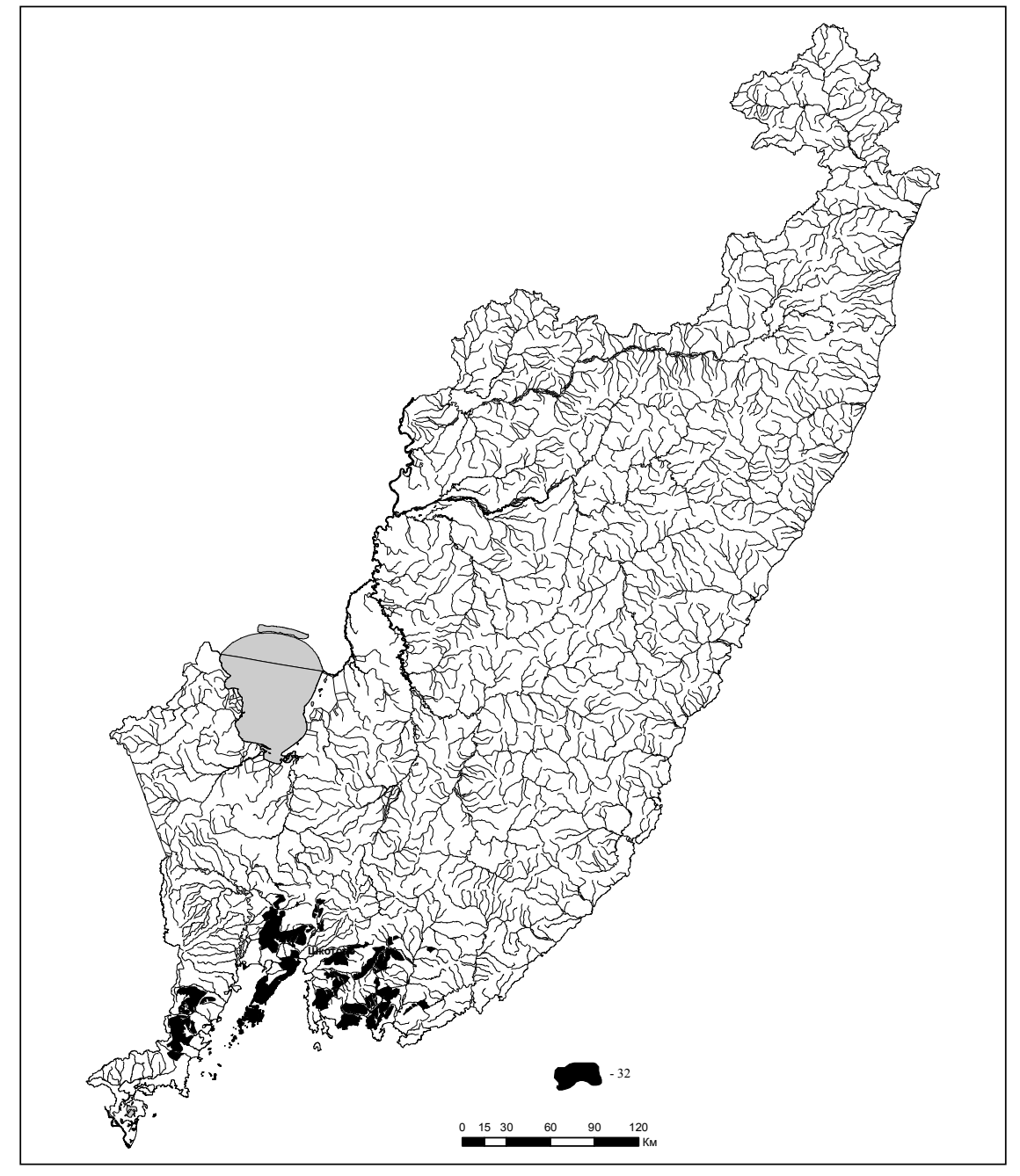

Puc. 47. Распространенность низкогорных грабово-широколиственных лесных ландшафтов горно-лесного смешанно-широколиственного пояса (32)

узких водоразделах и крутых склонах, слабосдержанный на широких водоразделах и выположенных склонах. Занимает площадь 483 кв. км, или 0,3\% площади края.

Вид ландшафтов дубняков (низкогорный терригенный род, горно-лесной смешанно-широколиственный пояс) (36) включает дубовые леса из дуба монгольского, их редколесья и порослевые 


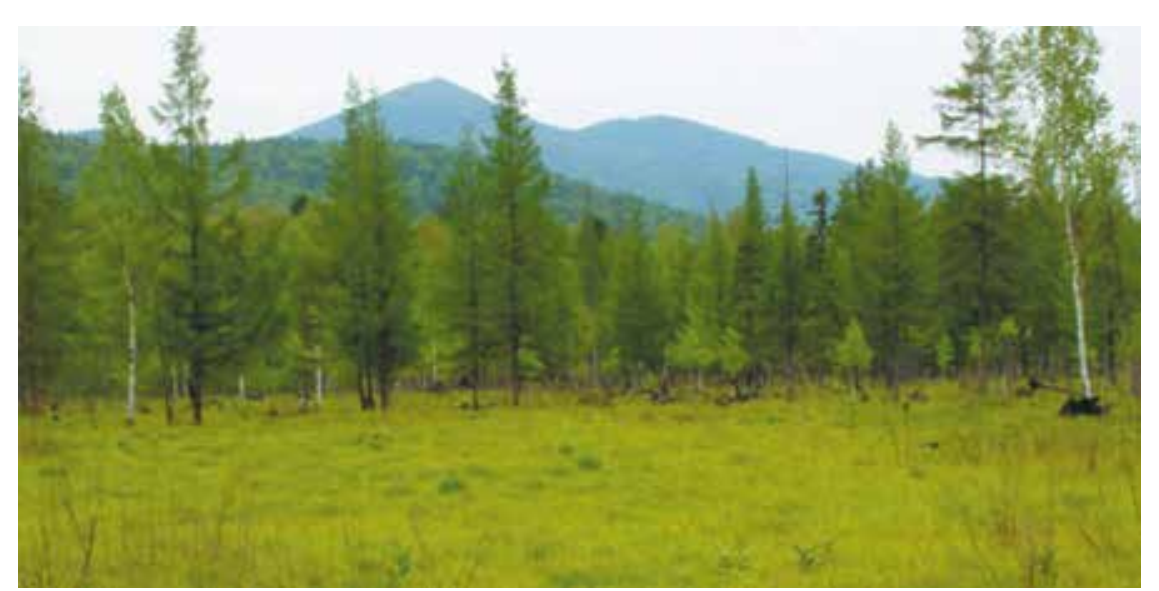

Pис. 48. Лиственничные леса в долинах рек Сихотэ-Алиня [7]

заросли на горно-лесных бурых слабокислых неоподзоленных и оподзоленных, горно-лесных, бурых кислых грубоскелетных почвах, имеет быстрый водообмен на узких водоразделах и крутых склонах, слабосдержанный на широких водоразделах и выположенных склонах. Занимает площадь 10379 кв. км, или 6,4\% площади края.

Вид ландшафтов пихтово-елово-лиственнично-мелколиственных лесов (низкогорный терригенный род, горно-лесной смешанношироколиственный пояс) (41) включает комплекс пихтово-еловых, лиственничных, елово-лиственничных и мелколиственных лесов (местами с широколиственными породами) на горно-таежных бурых, иллювиально-гумусовых оподзоленных и неоподзоленных, подзолистых, охристо-бурых, глеевато-оподзоленных почвах, имеет быстрый водообмен на узких водоразделах и крутых склонах, слабосдержанный на широких водоразделах и выположенных склонах. Занимает 2101 кв. км, или 1,3\% площади края.

Вид ландшафтов широколиственно-кедровых лесов (платобазальтовый род, горно-лесной смешанно-широколиственный пояс) ландшафтов (44, рис. 49) включает широколиственно-кедровые леса и чистые кедрачи на горно-лесных бурых кислых почвах, имеет затрудненный водообмен на слабонаклонных, иногда почти горизонтальных поверхностях. Занимает площадь 470 кв. км, или $0,25 \%$ плошади края.

Вид ландшафтов широколиственно-кедрово-еловых лесов (платобазальтовый род, горно-лесной смешанно-широколиственный

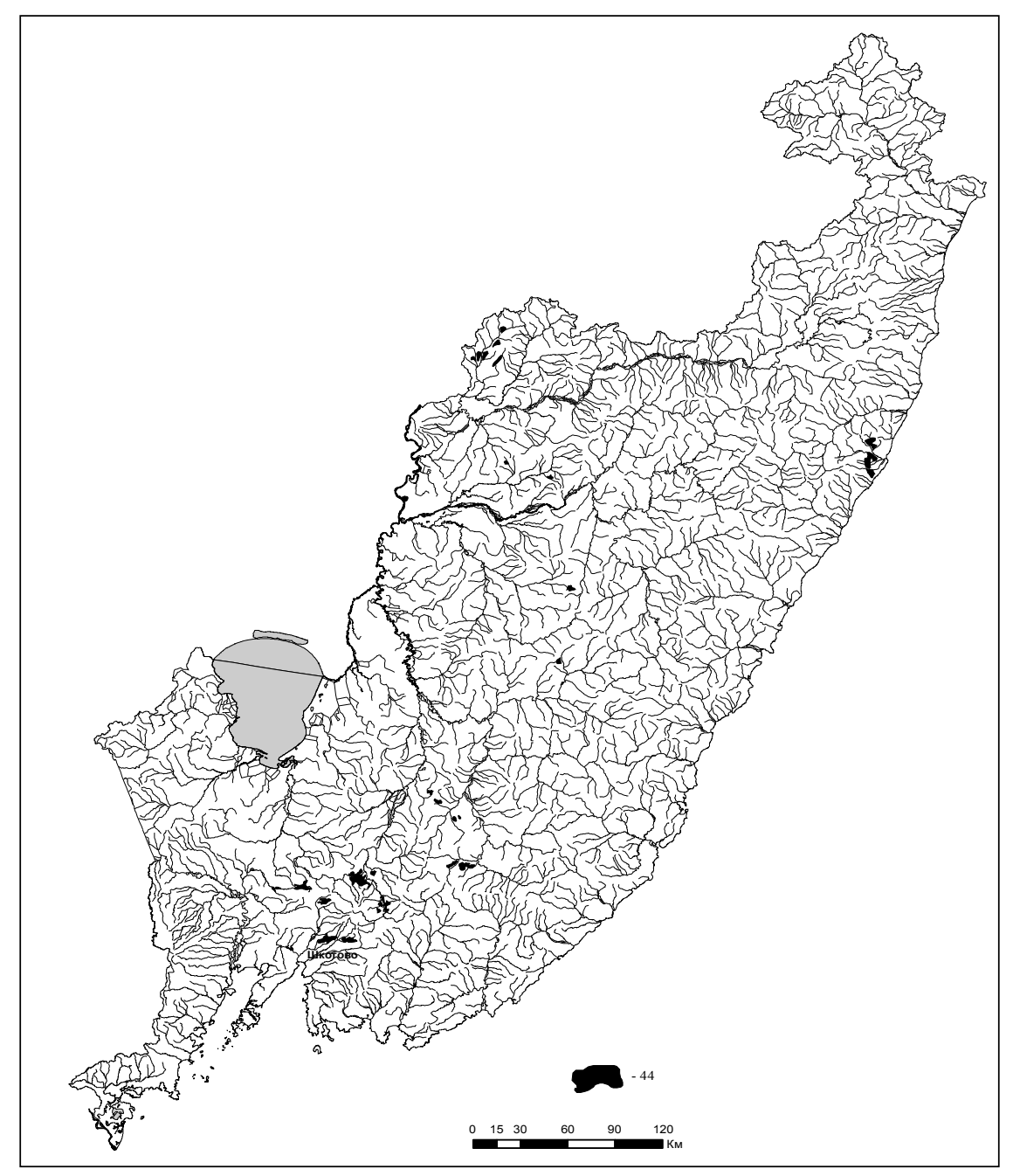

Рис. 49. Распространенность платобазальтовых широколиственнокедровых лесных ландшафтов горно-лесного смешанношироколиственного пояса (44)

пояс) (45) включает широколиственно-кедровые и кедрово-еловые леса на горно-таежных бурых неоподзоленных, глеевато- и глеевато-оподзоленных, реже горно-лесных бурых оподзоленных, и слабокислых неоподзоленных почвах, имеет затрудненный водообмен на слабонаклонных, иногда почти горизонтальных, поверхностях. Занимает площадь 1270 кв. км, или 0,8\% площади края. 
Вид ландшафтов грабовых черно-пихтово-широколиственных лесов (платобазальтовый род, горно-лесной смешанно-широколиственный пояс) (46) включает грабовые широколиственно-кедровые леса с цельнолистной (черной) пихтой и черно-пихтово-широколиственными лесами на горно-лесных-бурых оподзоленных и слабокислых неоподзоленных почвах, имеет затрудненный водообмен на слабонаклонных, иногда почти горизонтальных, поверхностях. Занимает площадь 537 кв. км, или 0,3\% площади края.

Вид ландшафтов грабово-широколиственных лесов (платобазальтовый род, горно-лесной смешанно-широколиственный пояс) (47) включает грабовые широколиственные леса с липами, кленом и дубом монгольским, их редколесья и порослевые заросли на горно-лесных бурых кислых, желто-бурых, бурых слабокислых неоподзоленных и оподзоленных почвах, имеет затрудненный водообмен на слабонаклонных, иногда почти горизонтальных, поверхностях. Занимает площадь 251 кв. км, или 0, $15 \%$ площади края.

Вид ландшафтов лиственнично-хвойно-смешанных лесов (платобазальтовый род, горно-лесной смешанно-широколиственный пояс) (49, рис. 50) включает лиственничные леса горных заболоченных широких долин рек и межгорных котловин в комплексе с участками хвойных и смешанных лесов на горно-таежных охристо-бурых глеевато- и глеево-оподзоленных, торфянистои торфяно-глеевых почвах, имеет затрудненный водообмен на слабонаклонных, иногда почти горизонтальных поверхностях. Занимает площадь 1044 кв. км, или 0,6\% площади края.

Вид ландшафтов дубняков (платобазальтовый род, горно-лесной смешанно-широколиственный пояс) (50) включает дубовые леса из дуба монгольского, их редколесья и порослевые заросли на бурых отбеленных типичных и горно-таежных бурых неоподзоленных, глеевато- и глеево-оподзоленных, реже торфянистои торфяно-глеевых почвах, имеет затрудненный водообмен на слабонаклонных, иногда почти горизонтальных, поверхностях. Занимает площадь 2082 кв. км, или 1,1\% площади края.

Вид ландшафтов дубово-березовых разнотравных лесов (платобазальтовый род, горно-лесной смешанно-широколиственный пояс) (51) включает редколесья дуба монгольского и березы даурской, дубово-лещинно-леспедецевые заросли в комплексе со злаковоразнотравно-суходольными лугами и фрагментами луговых и горных степей на горно-лесных бурых оподзоленных и слабокислых неоподзоленных, бурых слабокислых, бурых глеевато-отбеленных,

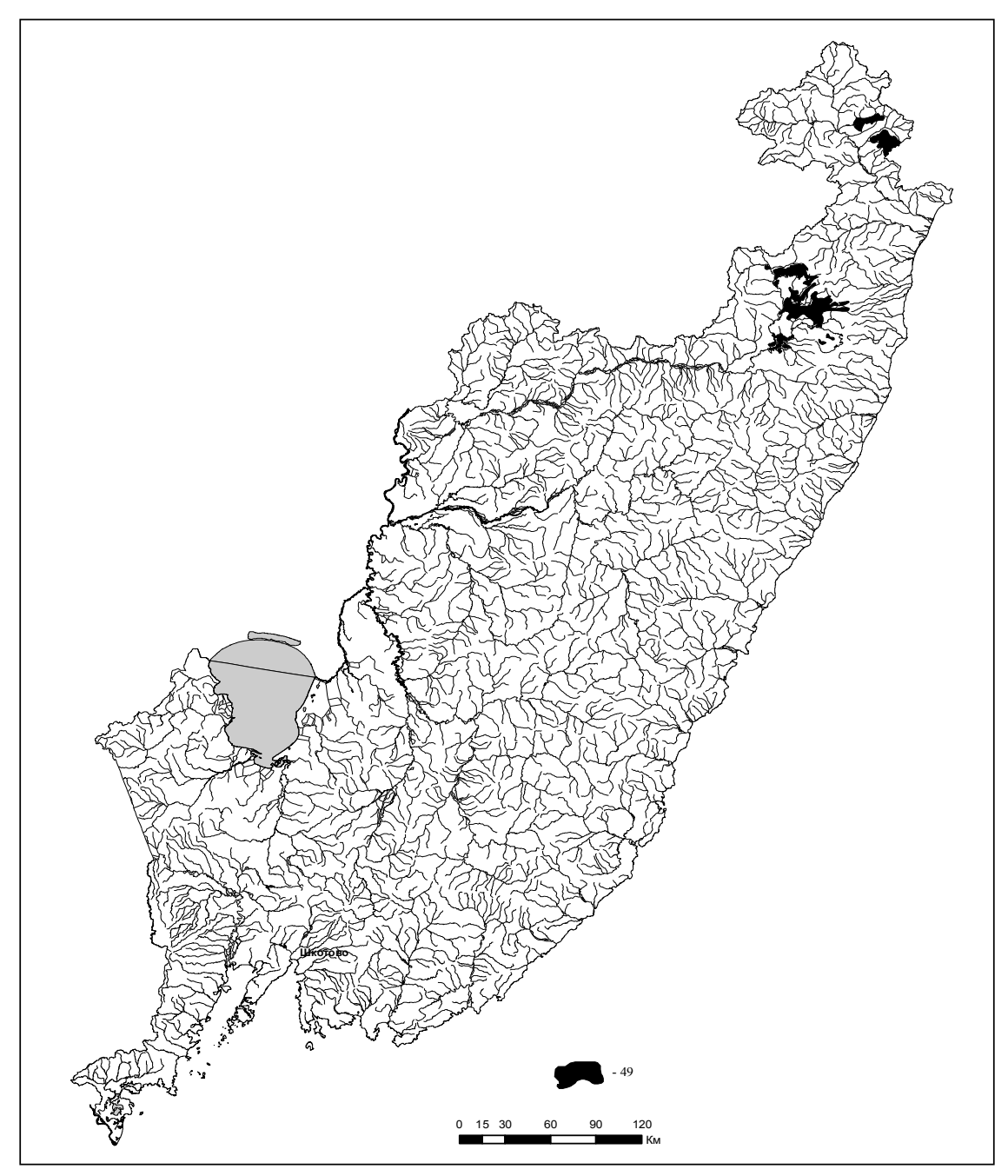

Puc. 50. Распространенность платобазальтовых лиственичнохвойно-смешанных лесных ландшафтов горно-лесного смешанношироколиственного пояса (49)

лугово-бурых отбеленных почвах, имеет затрудненный водообмен на слабонаклонных, иногда почти горизонтальных, поверхностях. Занимает площадь 518 кв. км, или 0,3\% площади края.

Вид ландшафтов мелколиственных лесов (платобазальтовый род, горно-лесной смешанно-широколиственный подкласс) (52) включает мелколиственные леса (береза, осина) на горно-таежных, 
охристо-бурых глеевато-оподзоленных и глеевых, оподзоленных и неоподзоленных почвах, имеет затрудненный водообмен на слабонаклонных, иногда почти горизонтальных, поверхностях. Занимает 344 кв. км, или 0,2\% площади края.

Пихтово-елово-лиственнично-мелколиственные леса тоже выделяются как вид ландшафтов (платобазальтовый род, горно-лесной смешанно-широколиственный пояс) (53). Он включает комплекс пихтово-еловых, лиственничных, елово-лиственничных и мелколиственных лесов (местами с широколиственными породами) на горно-таежных бурых, иллювиально-гумусовых оподзоленных и неоподзоленных, подзолистых, охристо-бурых, глеевато-оподзоленных почвах, имеет затрудненный водообмен на слабонаклонных, иногда почти горизонтальных, поверхностях. Занимает 2617 кв. км, или 1,6\% площади края.

Вид ландшафтов дубняков (55), аналог 50, различается по местоположению в рельефе (мелкосопочный полисубстратный род, горно-лесной смешанно-широколиственный пояс). Включает дубовые леса из дуба монгольского, их редколесья и порослевые заросли на горно-лесных бурых, слабокислых неоподзоленных и оподзоленных слабокислых, реже лесных бурых кислых, отбеленных и глеевато-отбеленных почвах, имеет слабосдержанный и затрудненный водообмен при малой крутизне склонов и вогнутом их профиле. Занимает 942 кв. км, или 0,6\% площади края.

Вид ландшафта дубово-березовых разнотравных лесов (мелкосопочный полисубстратный род, горно-лесной смешанно-широколиственный пояс) (56, рис. 51) включает редколесья дуба монгольского и березы даурской, дубово-лещинно-леспедецевые заросли в комплексе со злаково-разнотравно-суходольными лугами и фрагментами луговых и горных степей на горно-лесных бурых оподзоленных и слабокислых неоподзоленных, бурых слабокислых, бурых глеевато-отбеленных, лугово-бурых отбеленных почвах, имеет слабосдержанный и затрудненный водообмен при малой крутизне склонов и вогнутом их профиле. Занимает площадь 1626 кв. км, или 1,0\% площади края.

\section{2 Местности}

Поиск закономерностей в структуре и пространственной организации ландшафтов по петрографическому составу вещественных комплексов, условиям залегания кровли фундамента и региональному структурно-тектоническому их положению дал

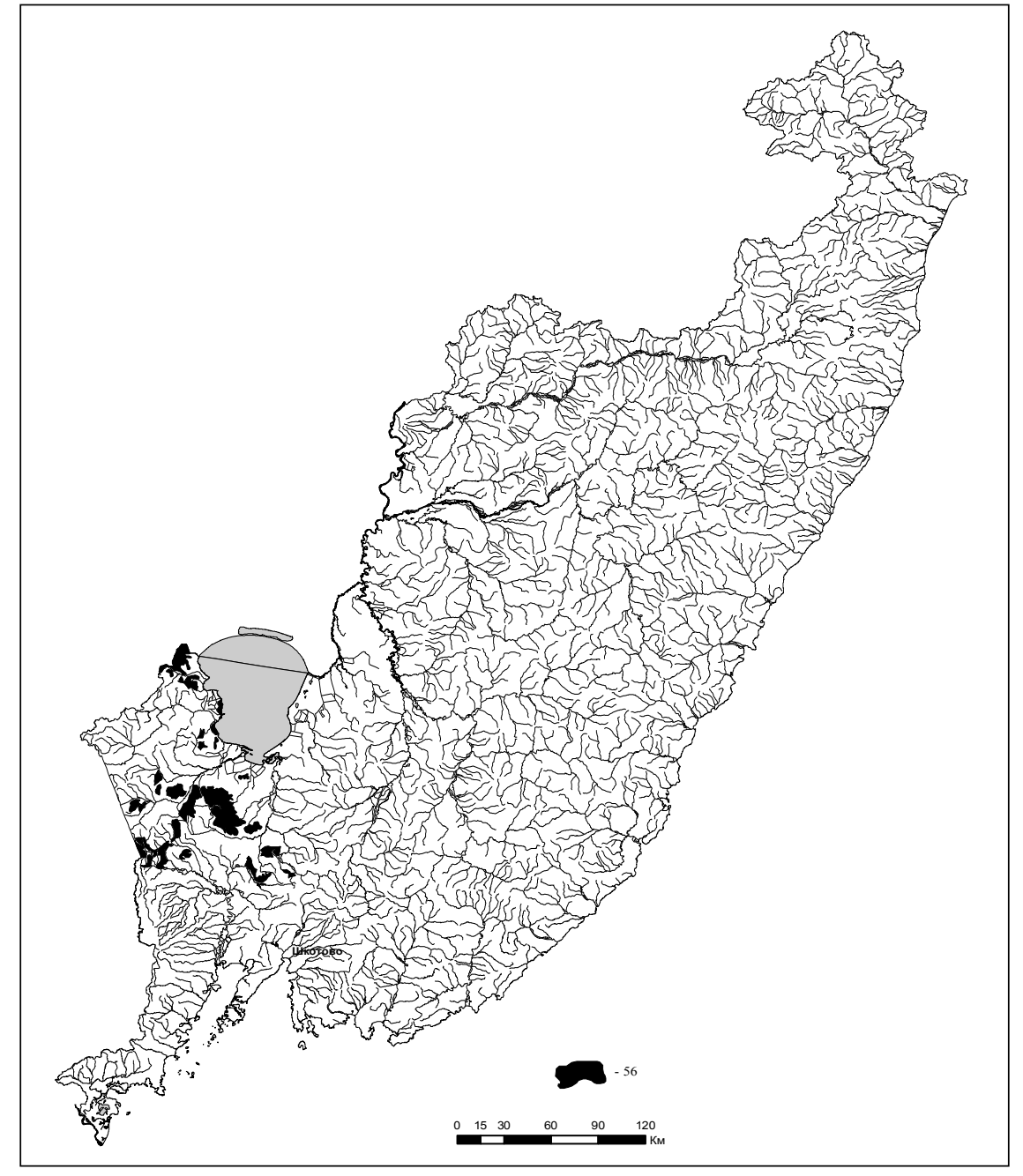

Рис. 51. Распространенность мелкосопочных дубово-березоворазнотравных лесных ландшафтов горно-лесного смешанношироколиственного пояса (56)

возможность, с учетом (во взаимосвязи, взаимопроникновении, взаимообусловленности) компонентов видов, родов и подклассов, выделить различное количество местностей, или индивидуальных ландшафтов, но с параметрами, позволяющими проводить их разделение на группы по некоторым признакам сходства. Всего нами выделено 3043 таких комплекса. 
Каждый из них, как отмечалось выше, характеризуется одним типом вещественных состава и условий их залегания в одних и тех же структурно-тектонических зонах, формах рельефа, условиях мезоклимата, при близких растительных и почвенных параметрах. Ниже мы приводим только пример характеристики структур части местностей (по одному из видов). Полное их описание опубликовано [226, 233, 244].

Местность 35-1 (низкогорный вулканогенно-терригенный род, низкогорный лиственнично-хвойно-смешанный вид) (35-1, $35-2,35-3, \ldots, 35-21$; здесь и далее $35-1$ : 35-номер вида на карте ландшафтов, $1,2, \ldots$ - номер местности на карте ландшафтов [243]) включает лиственнично-хвойно-смешанный лес, нижнепермский вулканитовый среднего состава комплекс, имеет глубину залегания кровли коренного фундамента до 5,0-8,0 м, сформировалась на склоне юго-западного побережья бухты Экспедиция. Занимает 10,2 кв. км, или 2,1\% площади вида, КР (коэффициент расчлененности) $-1,3$.

Местность 35-2 (низкогорный терригенный род, низкогорный лесной лиственично-хвойно-смешанный вид ландшафта) включает лиственнично-хвойно-смешанный лес, верхнепермский алевролит-песчаниковый комплекс, имеет глубину залегания кровли коренного фундамента до 5,0-8,0 м, сформировалась на склоне правобережья р. Пойма. Занимает 8,8 кв. км, или 1,8\% площади вида, КР-1,4.

Местность 35-3 (низкогорный вулканогенный род, низкогорный лиственично-хвойно-смешанный вид ландшафта) включает лиственнично-хвойно-смешанные леса, палеозойский допозднепермский гранитоидный комплекс, имеет глубину залегания кровли коренного фундамента до 3,0-5,0 м, сформировалась на склоне правобережья правого притока нижнего течения р. Партизанская. Занимает 4,3 кв. км, или 0,9\% площади вида, КР-1,4.

Местность 35-4 входит в низкогорный терригенный род, низкогорный лиственично-хвойно-смешанный вид ландшафта и включает лиственнично-хвойные леса, нижнемеловый алевролит-песчаниковый комплекс, имеет глубину залегания кровли коренного фундамента до 3,0-5,0 м, сформировалась на склоне верховья р. Осиновка. Занимает 7,3 кв. км, или 1,5\% площади вида, КР-1,1.

Местность 35-5 (низкогорный вулканогенно-терригенный род, низкогорный лиственично-хвойно-смешанный лесной вид ландшафта) это лиственнично-хвойно-смешанный лес на склонах, мезозойский вулканогенно-кремнисто-песчаниковый, нижнемеловой алевролит-песчаниковый комплекс, имеет глубину залегания кровли коренного фундамента до 3,0-5,0 м, сформировалась местность на склонах правобережья верхнего течения р. Черная. Занимает 57,8 кв. км, или 12,0\% площади вида, КР-1,4.

Местность 35-6 (низкогорный терригенный род, низкогорный лиственично-хвойно-смешанный лесной вид ландшафта) включает лесные склоновые поверхности, мезозойский алевролит-песчаниковый комплекс, имеет глубину залегания кровли коренного фундамента до 3,0-5,0 м. Местность сформировалась на склоне правобережья верховья р. Партизанская. Занимает 6,9 кв. км, или 1,4\% площади вида, КР-1,3.

Местность 35-7 (низкогорный вулканогенный род, низкогорный лиственично-хвойно-смешанный лесной вид ландшафта) включает лиственнично-хвойно-смешанные склоновые и гривные леса. Верхнемеловый вулканитовый кислого состава комплекс имеет глубину залегания кровли коренного фундамента до 3,0-5,0 м, сформировалась на водораздельной гриве и склонах междуречья нижних течений рек Милоградовка и Маргаритовка. Занимает 26,5 кв. км, или 5,5\% площади вида, КР-1,4.

Местность 35-8 (низкогорный терригенный род, низкогорный лиственично-хвойный лесной вид) включает лиственнично-хвойно-смешанные леса, нижнепермский алевролит-песчаниковый комплекс, имеет глубину залегания кровли коренного фундамента до 5,0-8,0 м, сформировался на склоне правобережья среднего течения р. Шкотовка. Занимает 27,1 кв. км, или 5,7\% площади вида, КР-1,6

Местность 35-9 (низкогорный терригенный род, лесной лиственично-хвойно- смешанный вид ландшафта) включает лиственнично-хвойно-смешанные склоновые леса, нижнепермский алевролит-песчаниковый комплекс, имеет глубину залегания кровли коренного фундамента до 5,0-8,0 м, сформировалась на склоне правобережья верхнего течения р. Шкотовка. Занимает 14,7 кв. км, или 3,0\% площади вида, КР-2,1.

Подводя итоги представления организационной структуры ландшафтов и построения иерархической схемы соподчинения различных подразделений по уровням сверху вниз, следует сделать следующий вывод. Региональная система ландшафтов, отражающая пространственно-площадную горизонтальную и высотную дифференциацию территории, на основе построенных ландшафтных и физико-географической карт, выводов по таксономической 
иерархии ландшафтов, включает 2 класса (горный, равнинный), 4 подкласса (горно-тундровый, горно-темнохвойный, горнолесной смешанно-широколист-венный, равнинный лесостепной и долинно-речной интразональный (парагенетический), 12 родов (гольцовый полисубстратный, массивно-среднегорный полисубстратный, расчленено-среднегорный полисубстратный, низкогорный терригенный и вулканогенно-терригенный, мелкосопочный полисубстратный и др.), 94 вида и 3043 структурных единиц ранга местностей. Всего выделено и отражено на картах 3158 гетерогенных взаимосвязанных и взаимообусловленных выделов ландшафтов. Эта работа, потребовавшая 15 лет, для Приморского края проведена впервые.

\section{Контрольные вопросы}

1. Раскройте понятие вид ландшафтов.

2. Охарактеризуйте лишайниково-кустарниковый вид ландшафтов (горно-тундровый пояс).

3. Охарактеризуйте вид ландшафтов хвойнозеленомошных лесов (горно-темнохвойный пояс).

4. Дайте характеристику вида ландшафтов широколиственнокедровых лесов (горно-лесной смешанно-широколиственный пояс).

5. Охарактеризуйте вид ландшафтов широколиственно-кедрово-еловых лесов (горно-лесной смешанно-широколиственный пояс).

6. Дайте характеристику вида ландшафтов грабово-широколиственных лесов (горно-лесной смешанно-широколиственный пояс).

7. Дайте характеристику вида ландшафтов широколиственных лесов (горно-лесной смешанно-широколиственный пояс).

8. Дайте характеристику вида ландшафтов дубовых лесов (горно-лесной смешанно-широколиственный пояс).

9. Как дифференцируются виды ландшафтов по родам ландшафтов?

10. Раскройте понятие местность.

11. Приведите примеры местностей и дайте их характеристику.

12. Охарактеризуйте местности по родам ландшафтов в связи с поясностью.

\section{Лекция 12}

\section{ЛАНДШАФТНЫЙ АНАЛИЗ И СИНТЕЗ КАК ОСНОВА КОМПЛЕКСНОЙ ОЦЕНКИ АНТРОПОГЕННЫХ ПРЕОБРАЗОВАНИЙ ПРИРОДНОЙ СРЕДЫ ПРИМОРЬЯ}

Как было показано в предыдущих лекциях, в результате графического отображения обширной и детальной информации по ландшафтам региона составлена «Карта ландшафтов Приморского края масштаба 1:500000»[232, 243]. Вслед за этим сама карта, представляющая пространственно-иерархическую модель ландшафтного покрова, подверглась детальному анализу для выявления закономерностей размещения геосистем и осмыслению отображенной на ней информации. При детальном анализе пространственного распределения ландшафтов применен статистический метод, призванный упорядочить фактический материал, многочисленные характеристики: пространственные, морфологические, климатические, гидрологические, геологические и ландшафтные (Плюснин, 2003). Большое количество показателей используется для характеристики ландшафтных структур (А. С. Викторов [25], Б. В. Виноградов [26]), что подтверждает как сложность организационной структуры ландшафтов, так и невозможность её точного математического описания. Данные по отдельным характеристикам ландшафтов, показатели количественных факторов отражающих ландшафтную дифференциацию достаточно многочисленны и очень важны для ландшафтной географии, что особенно актуально для горных стран (В. М. Плюснин [157], Д. В. Черных [282]).

Фактический материал для статистической обработки. Все количественные характеристики, снимаемые с карты, разделяются на группы пространственных, морфологических и ландшафтных данных.

Пространственные данные характеризуют прежде всего расположение исследуемых ландшафтов на земном шаре. Даны их 
географические координаты - широта и долгота, охарактеризованы крутизна склонов, удаление от моря, а также средние и максимальные высоты.

Морфологические данные определяют морфологическое строение ландшафтов - амплитуду высот, вертикальную и горизонтальную расчлененность. Значения горизонтального и вертикального расчленения вычислены по известным формулам:

$$
\mathrm{a}=\Sigma \dot{\mathrm{L}} / \mathrm{S} \text { и в }=10 \Delta \mathrm{H} / \mathrm{S} \text {. }
$$

Ландшафтные количественные параметры получены по карте ландшафтов Приморского края масштаба 1: 500000 . Подсчитано общее количество ландшафтных контуров (n), количество контуров каждого таксона ландшафтов $\left(\mathrm{n}_{1}\right)$, площадь каждого ландшафта $(\mathrm{S})$, определен процент соотношения площадей ландшафтов и площади региона.

Вычислен коэффициент сложности $\left(\mathrm{K}_{\mathrm{cл}}=\mathrm{n} / \mathrm{S}_{\mathrm{o}}\right)$, коэффициент ландшафтной раздробленности $\left(\mathrm{S}_{\mathrm{o}} / \mathrm{S}\right)$. Подсчет подклассов, родов, видов ландшафтов, плошадей, занимаемых отдельными контурами ландшафтов позволили определить энтропийную меру общего разнообразия по формуле Шеннона.

$$
\mathrm{H}=-\mathrm{S}_{1} / \mathrm{S} \log \mathrm{S}_{1} / \mathrm{S} \text {. }
$$

Максимальная энтропия $\left(\mathrm{H}_{\max }\right)$ равна $\log 2 \mathrm{~m}$. Арифметические действия с последними показателями определяют энтропийную меру неуравновешенности ландшафтной структуры

$$
\mathrm{H}_{1}=\mathrm{H}_{\max }-\mathrm{H}
$$

и показатель упорядоченности структуры

$$
\mathrm{H}_{3}=1-\mathrm{H} / \mathrm{H}_{\max } \text {. }
$$

Проведен корреляционный анализ количественных характеристик подклассов и видов ландшафтов.

Анализ распределения ландшафтов по группе ландшафтных данных. Ниже на примере картографо-статистических данных по родам и видам рассматриваются площадная пространственная дифференциации ландшафтов и результаты установленных статистических количественных закономерностей для территории Приморского края (количественные данные по площадям подклассов, родов, видов и местностей, их процентным соотношениям опубликованы [232, 243]).
Среди ландшафтов региона доминантными являются ландшафты низкогорного терригенного рода горно-лесного смешанношироколиственного подкласса, они занимают 47351,9 кв. км, что составляет 29,4\% площади края (табл. 13, рис. 52a, 526). За ними следуют равнинные и долинно-речные ландшафты эрозионноаккумулятивного рода, занимающие 41215,7 кв. км, что составляет $25,4 \%$ площади региона. Редкие - ландшафты приморских равнин приморского равнинного рода с площадью 596,1 кв. км, что составляет 0,4\%, а также близкие по площади (608,8 кв. км) и занимаемому ими проценту от площади Приморья $(0,9 \%)$ ландшафты гольцового полисубстратного рода горно-тундрового

\begin{tabular}{|c|c|c|c|}
\hline $\begin{array}{l}\text { Подкласс } \\
\text { ландшафтов }\end{array}$ & Род ландшафтов & $\begin{array}{l}\text { Пло- } \\
\text { щадь, } \\
\text { кв. км }\end{array}$ & $\begin{array}{c}\text { Площадь } \\
\text { края, \% }\end{array}$ \\
\hline $\begin{array}{l}\text { Горно-тун- } \\
\text { дровый }\end{array}$ & Гольцовый полисубстратный & 608,8 & 0,9 \\
\hline \multirow{4}{*}{$\begin{array}{l}\text { Горно- } \\
\text { темнохвой- } \\
\text { ный }\end{array}$} & $\begin{array}{l}\text { Массивно-среднегорный поли- } \\
\text { субстратный }\end{array}$ & 3978,9 & 2,5 \\
\hline & $\begin{array}{l}\text { Расчленено-среднегорный по- } \\
\text { лисубстратный }\end{array}$ & 12208,7 & 17,7 \\
\hline & $\begin{array}{l}\text { Низкогорный вулканогенно- } \\
\text { терригенный }\end{array}$ & 2364,8 & 1,5 \\
\hline & Платобазальтовый & 2597 & 1,6 \\
\hline \multirow{6}{*}{$\begin{array}{l}\text { Горно-лесной } \\
\text { смешанно- } \\
\text { широколист- } \\
\text { венный }\end{array}$} & $\begin{array}{l}\text { Массивно-среднегорный поли- } \\
\text { субстратный }\end{array}$ & 8665,7 & 5,3 \\
\hline & $\begin{array}{l}\text { Расчленено-среднегорный по- } \\
\text { лисубстратный }\end{array}$ & 28628,4 & 17,7 \\
\hline & Низкогорный терригенный & 47351,9 & 29,4 \\
\hline & Платобазальтовый & 9657,9 & 6,0 \\
\hline & Мелкосопочный полисуьстратный & 4229,6 & 2,6 \\
\hline & Приморско-равнинный & 596,1 & 0,4 \\
\hline $\begin{array}{l}\text { Лесостепной } \\
\text { равнинный и } \\
\text { долинно-реч- } \\
\text { ной }\end{array}$ & $\begin{array}{l}\text { Эрозионно-аккумулятивно-рав- } \\
\text { нинный и долинно-речной }\end{array}$ & 41215,7 & 25,4 \\
\hline
\end{tabular}

\section{Таблица 13}

\section{Площадь распространения родов ландшафтов Приморского края} (по подклассам ландшафтов, фрагмент) 

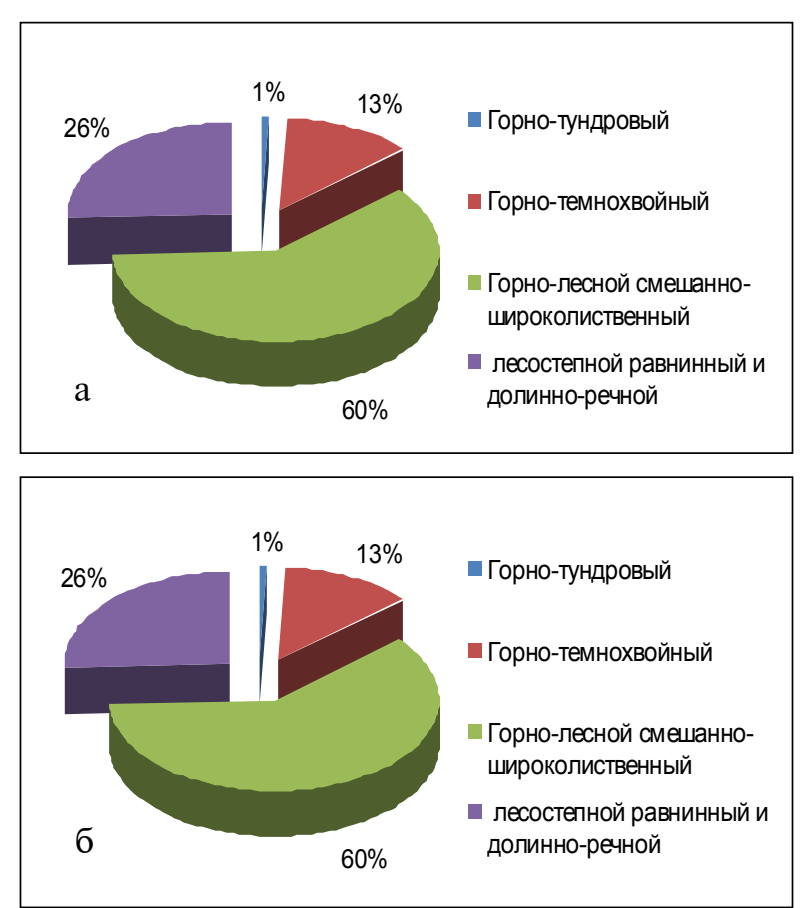

Puc. 52. Соотношение площадей подклассов ландшафтов: $a-$ в процентах, $\sigma-$ в Кв. км

подкласса. Значительную площадь $(28628,4$ кв. км) и большую долю площади края $(17,7 \%)$ имеют ландшафты среднегорнорасчлененного полисубстратного рода горно-лесного смешанношироколист-венного подкласса, а также ландшафты расчленено-среднегорного полисубстратного рода горно-темнохвойного подкласса площадью 12208,7 кв. км, что составляет 7,5\% площади края. Значительная часть ландшафтов массивно-среднегорного полисубстратного, мелкосопочного полисубстратного и других родов горно- темнохвойного, горно-лесного смешанно-широколиственного подклассов имеют площади от 8665,7 кв. км, или долю площади края от 5,4\% (массивно-среднегорный полисубстратный род горно-темнохвойного подкласса) и 9657,9 кв. км, или 5,9\% (платобазальтовый род горно-лесного смешанно-широколиственного подкласса) до 2364,8 кв. км, или $1,5 \%$ (низкогорный терригенный род горно-темнохвойного подкласса) и 2597,1 кв. км, или долю 1,6\% (платобазальтовый род горно-темнохвойного подкласса).
Горно-темнохвойный, горно-лесной смешанно-широколиственный, лесостепной равнинный и долинно-речной подклассы дифференцированы по плошадям родов ландшафтов. В отмеченных подклассах роды ландшафтов для статистической обработки и построения диаграмм объединены в родовые группы. Отдельно по родам в горно-темнохвойном подклассе, представленном массивно-среднегорным полисубстратном, расчленено-среднегорным полисубстратным, низкогорным вулканогенно-терригенным и платобазальтовым родами ландшафтов, наибольшую площадь в 12208,7 кв. км (рис. 53) занимают ландшафты расчлененосреднегорного полисубстратного рода с наиболее возвышенными узкими хребтами и обособленными вершинами с глубоко расчлененными и прямыми склонами с абс. отм. более 800 м, с густотой расчленения $1,0-2,0$ км/Кв. км и глубиной вреза до 300-700 м. Наименее распространены ландшафты низкогорного вулканогенно-терригенного рода с площадью 2364,8 кв. км с горными хребтами и вершинами с абс. отм. 300-800 м, прямыми, реже выпуклыми склонами различной крутизны, с густотой расчленения $0,4-0,8$ км/Кв. Км, глубиной вреза до $100-400$ м. К ландшафтам низкогорного вулканогенно-терригенного рода близки по площади ландшафты платобазальтового рода (2 597,0 кв. км.), они со слабонаклонными или горизонтальными поверхностями, с абс. отм. от первых десятков до 1500 м, с обрывистыми уступами и обвально-оползневыми накоплениями в краевых частях, с густотой расчленения от 0 до $0,5-0,8$ км/Кв. Км и глубиной вреза от первых метров до прорезания на полную мощность накоплений с углублением в подбазальтовые породы. Характерные - ландшафты массивносреднегорного полисубстратного рода (площадь

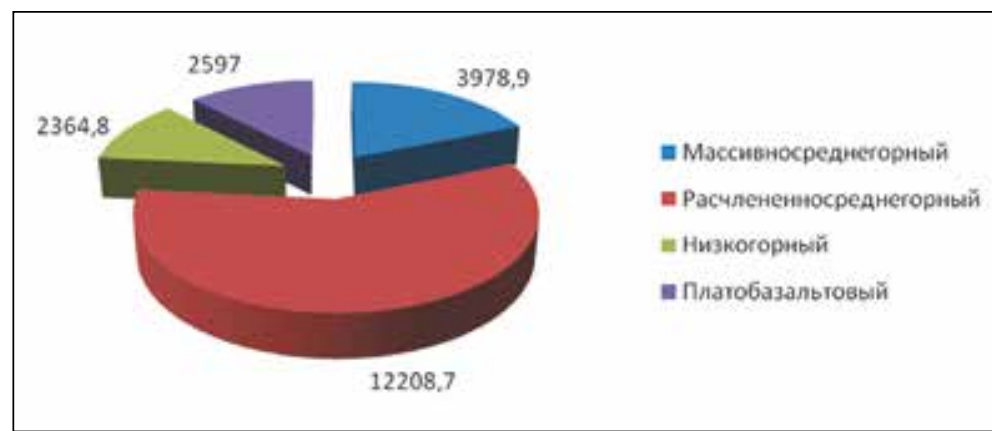

Puc. 53. Родовые группы горно-темнохвойного подкласса ландшафтов, кв. км 
3978,9 кв. км) с абс. отм. более 800 м, с куполовидными массивами и горными кряжами, выпуклым профилем склонов и средней их крутизной, с густотой расчленения $0,6-1,0$ км/Кв. Км, глубиной вреза до 200-300 м. Отмеченное показывает, что по распространенности ландшафтных родов в горно-темнохвойном подклассе установлен ряд распространенности от доминантных к редким: расчленено-среднегорный полисубстратный, массивносреднегорный полисубстратный, платобазальтовый, низкогорный вулканогенно-терригенный.

В горно-лесном смешано-широколиственном подклассе, представленном массивно-среднегорным полисубстратным, расчленено-среднегорным полисубстратным, низкогорным терригенным, платобазальтовым и мелкосопочным полисубстратным родами ландшафтов, наибольшую площадь в 47351 кв. км (рис. 54) занимают ландшафты низкогорного теригенного рода с горными хребтами и вершинами с абс. отм. 300-800 м, прямыми, реже выпуклыми, склонами различной крутизны, с густотой расчленения 0,4-0,8 км/кв. км, глубиной вреза до 100-400 м. Характерные - ландшафты расчленено-среднегорного полисубстратного рода (площадь 28628,4 кв. км) с абс. отм. более 800 м, с наиболее возвышенными узкими хребтами и обособленными вершинами с глубоко расчлененными и прямыми склонами с абс. отм. более 800 м, с густотой расчленения $1,0-2,0$ км/кв. км и глубиной вреза до 300-700 м. Меньшую площадь занимают ландшафты платобазальтового рода с площадью в 9657,9 кв. км со слабонаклоненными или горизонтальными поверхностями с абс. отм. от первых десятков до 1200 м, с обрывистыми уступами и обвально-оползневыми накоплениями в краевых частях, с густотой расчленения от

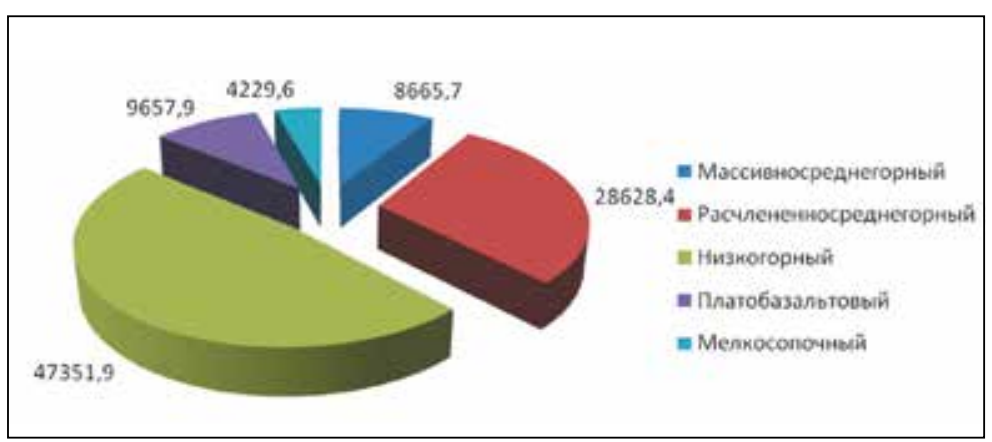

Puc. 54. Родовые группы горно-лесного смешанношироколиственного подкласса ландшафтов, кв. км
0 до 0,5-0,8 км/Кв. км и глубиной вреза от первых метров до прорезания на полную мощность накоплений с углублением в подбазальтовый фундамент. Еще меньшую площадь в 8665,7 кв. км занимают ландшафты массивно-среднегорного полисубстратного рода с абс. отм. более 800 м, с куполовидными массивами и горными кряжами, выпуклым профилем склонов и средней их крутизной, с густотой расчленения $0,6-1,0$ км/кв. км, глубиной вреза до 200-300 м. Наименьшую плошадь в 4229,6 кв. км занимают ландшафты мелкосопочного полисубстратного рода с отдельными вершинами и грядами возвышенностей с абс. отм. менее 300 м, с малой крутизной склонов, вогнутым профилем, с густотой расчленения $0,2-0,4$ км/кв. км, глубиной вреза менее 200 м. Дифференциация ландшафтов по распространенности отдельных родов в горно-лесном смешанно-широколиственном подклассе (от доминантных к редким): низкогорный терригенный, расчленено-среднегорный полисубстратный, платобазальтовый, массивно-среднегорный полисубстратный, мелкосопочный полисубстратный.

В лесостепном равнинном и долинно-речном подклассе, представленном эрозионно-аккумулятивно-равнинным и долинноречным и приморско-равнинным родами ландшафтов, наибольшую площадь в 41215,7 кв. км (рис. 55) занимают ландшафты эрозионно-аккумулятивно-равнинные и долинно-речные, развитые на Уссури-Ханкайской равнине и включающие речные долины Сихотэ-Алинской и Восточно-Маньчжурской горных территорий. Центральную часть равнины занимает Приханкайская низменность, по периферии которой расположены слаборасчлененные террасы. Среди равнины возвышаются отдельные

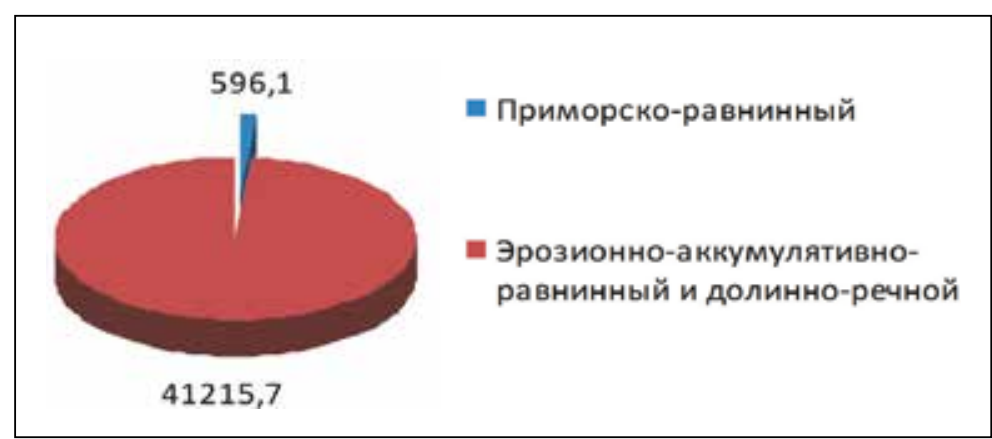

Puc. 55. Роды лесостепного равнинного и долино-речного подклассов ландшафта, кв. км 
останцовые сопки и мелкогорные возвышенности. Равнинные и долинно-речные ландшафты характеризуются преобладанием эрозионного происхождения обломочного материала, преимущественно его водным транзитом и накоплением в условиях малых уклонов поверхностей. Наименьшую площадь в 596,1 кв. км занимают ландшафты приморско-равнинного рода, развитые на выровненных низинных, устьевых частях рек, районов развития бухт, заливов в прибрежной полосе Приморского края.

Ландшафты видового ранга (их 94), так же, как и роды, значительно дифференцированы по плошади и соотношению в родах, а также по их распространенности в Приморье (табл. 14). Наибольшую площадь (14507 кв. км) и долю $(9,1 \%)$ площади края занимает вид ландшафтов с широколиственно-кедровыми и кедровыми лесами на горно-лесных бурых, слабокислых неоподзоленных и оподзоленных почвах, а также горно-темнохвойного подкласса вид ландшафтов с пихтово-еловыми лесами на горнотаежных бурых иллювиально-гумусовых неоподзоленных и оподзоленных почвах, с площадью 12047,5 кв. км, или 7,5\% площади края. Характерный (103379 кв. км, или 6,4\%) вид ландшафтов с дубовыми лесами, их редколесьями и порослевыми зарослями на горно-лесных бурых слабокислых неоподзоленных и оподзоленных, горно-лесных бурых кислых грубоскелетных почвах. Наименьшую площадь (4,7 кв. км) и процент $(0,003 \%)$ имеет вид ландшафта с дубовыми лесами, их редколесьями и порослевыми зарослями с участками вейниковых, осоко-вейниковых и разнотравно-злаковых лугов в комплексе с низинными осоковыми болотами и освоенными землями на задернованных слоистых остаточно-пойменных, бурых лесных почвах (приморско-равнинный род ландшафта). Значительная часть видов ландшафтов имеет площади от 1027 до 7598 кв. км и соответственно составляют от 0,6 до 4,7\% плошади края.

Виды ландшафтов связаны с родами и подклассами ландшафтов: горно-темнохвойным, горно-лесным смешанно-широколиственным, лесостепным равнинным и долинно-речным. В горнотемнохвойном подклассе, представленном массивно-среднегорным полисубстратным, расчленено-среднегорным полисубстратным, низкогорным вулканогенно-терригенным и платобазальтовым родами ландшафтов, наибольшую площадь в 12047,5 кв. км и 7,5\% площади края, занимают ландшафты хвойно-зеленомошного вида расчленено-среднегорного полисубстратного рода, развитых на наиболее возвышенных куполовидных массивах Сихо-

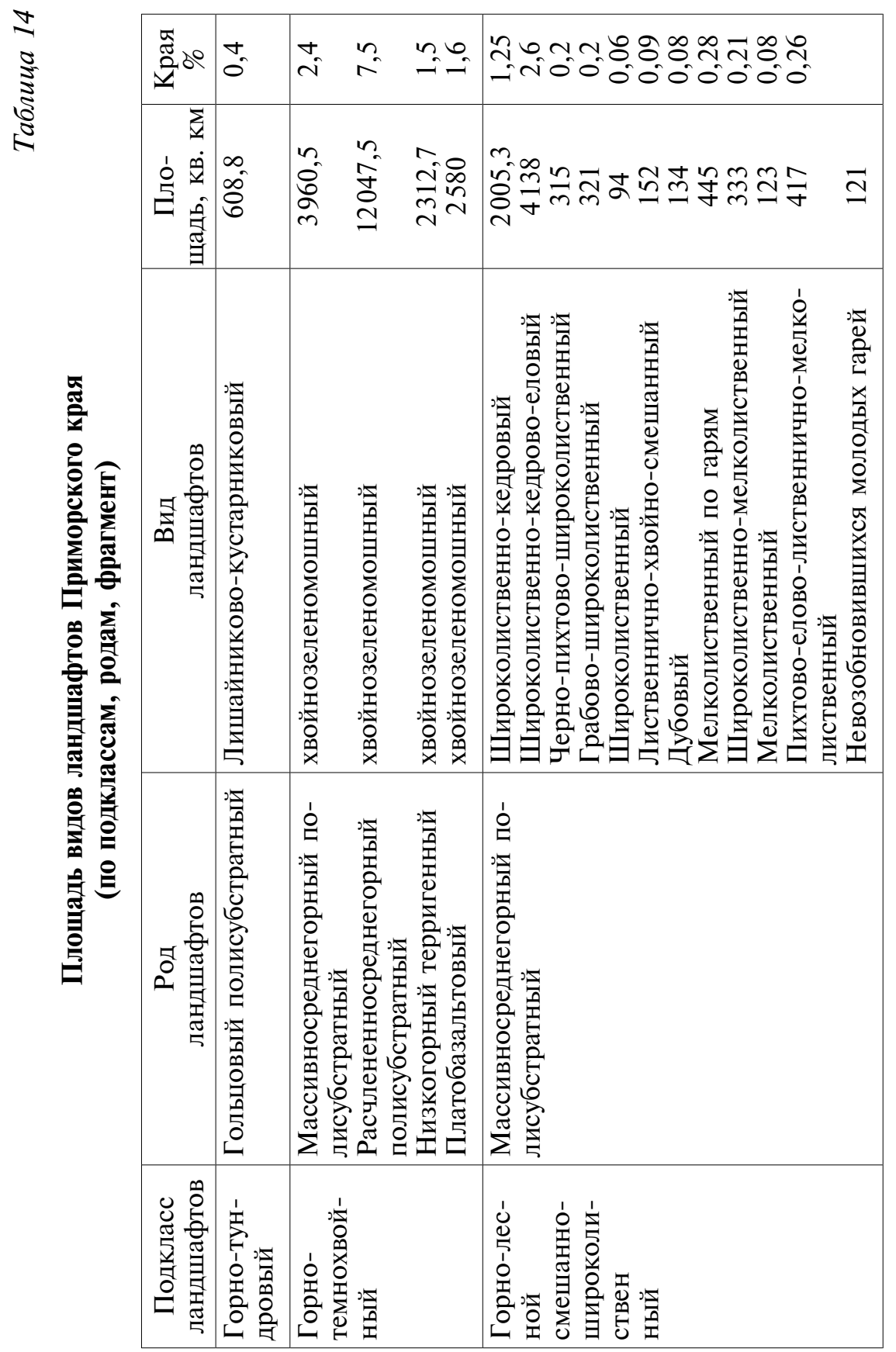


тэ-Алиня.. Значительную часть занимают (3960,5 кв. км, или $2,4 \%$ от площади края) ландшафты хвойно-зеленомошного вида массивно-среднегорного полисубстратного рода. Затем по распространенности следуют ландшафты хвойно-зеленомошного вида платобазальтового рода. Они занимают 2580 кв. км, или $1,6 \%$ площади края. Наименее развиты ландшафты хвойно-зеленомошного вида низкогорного вулканогенно-терригенного рода с площадью 2312,7 кв. км, или 1,5\% от площади края.

Виды ландшафтов по родам горно-лесного смешанно-широколиственного подкласса дифференцированы больше, чем горно-темнохвойного, и разделяются на массивно-среднегорный, расчленено-среднегорный полисубстратный, низкогорный терригенный, платобазальтовый, мелкосопочный полисубстратный.

Массивно-среднегорный полисубстратный род дифференцирован на 12 видов ландшафтов (табл. 14). Доминантный на территории массивно-среднегорного полисубстратного рода ландшафтов широколиственно-кедрово-еловый лесной вид на горно-лесных бурых почвах, его площадь 4138,0 кв. км (рис. 56), что составляет $2,6 \%$ от площади края. Широко развит на площади 2005,3 кв. км (1,25\% от площади края) широколиственно-кедровый лесной на горно-лесных бурых почвах вид ландшафтов. Менее развит на площади 445 кв. км, занимающий $0,28 \%$ площади края,

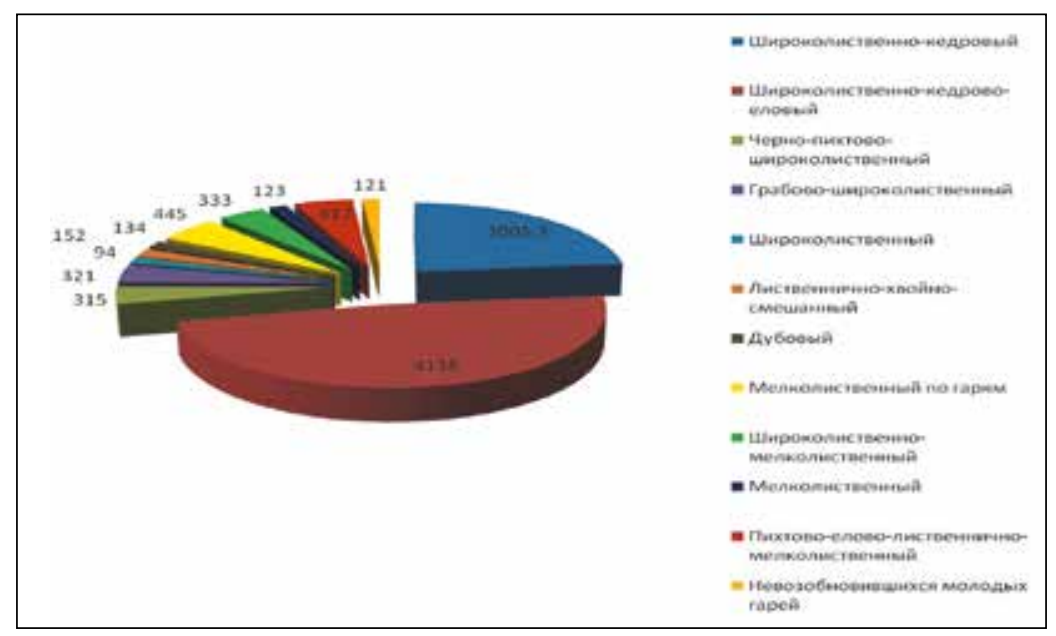

Рuc. 56. Виды лесных ландшафтов массивносреднегорного полисубстратного рода горно-лесного смешанно-широколиственного подкласса, кв. км мелколиственно-лесной по гарям на горно-лесных почвах вид. В модели распространенности видов ландшафтов, все остальные, в частности грабово-широколиственный лесной на горно-лесных бурых почвах, широколиственный лесной на горно-лесных бурых почвах, мелколиственно-лесной на горно-лесных бурых почвах и др., занимают площади от 94 до 333 кв. км, что составляет соответственно 0,06 до 0,21\% площади края. Анализ картографостатистических данных по дифференциации и распространению видов ландшафтов в целом по массивно-среднегорному полисубстратному роду показывает, что они создают ряд от доминантных к редким: широколиственно-кедрово-еловый, широколиственнокедровый, мелколиственный по гарям, пихтово-елово-лиственнично-мелколиственный, широколиственно-мелко-лиственный, грабово-широколиственный, черно-пихтово-широколиственный, лиственнично-хвойно- смешанный, дубовый, мелколиственный, невозобновившихся молодых гарей, широколиственный.

Расчленено-среднегорный полисубстратный род ландшафтов Приморского края дифференцирован на 11 видов ландшафтов. Наиболее развит на территории расчленено-среднегорного полисубстратного рода ландшафтов широколиственно-кедровоеловый лесной на горно-лесных бурых почвах вид с площадью 7598,0 кв. км (рис. 57), занимающий 4,7\% от площади края. На

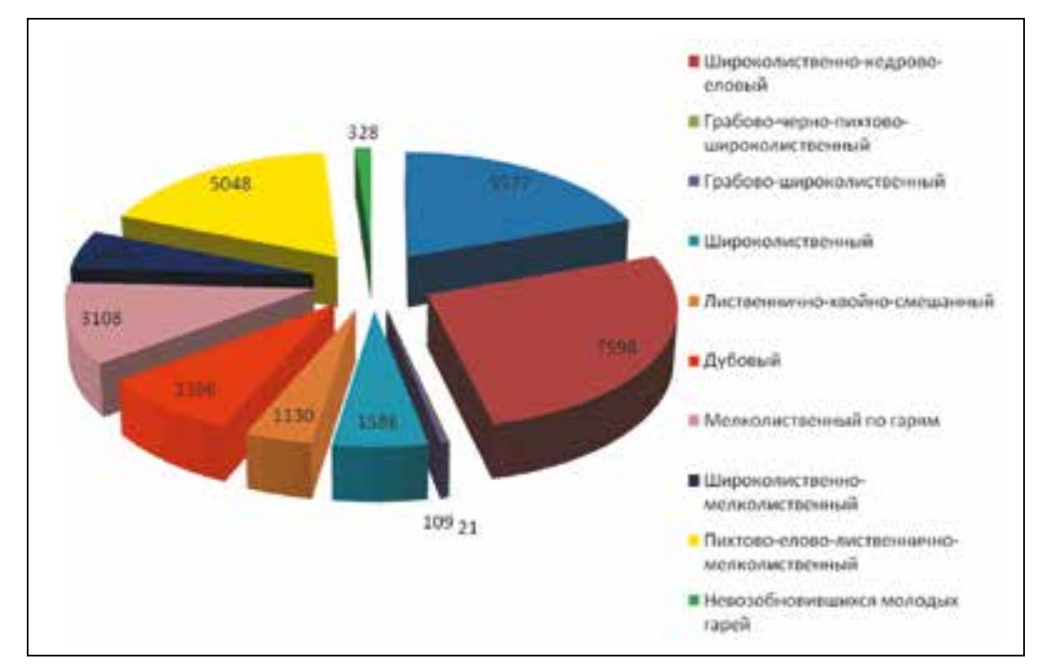

Puc. 57. Виды ландшафтов расчленено-среднегорного полисубстратного рода горно-лесного смешанно-широколиственного подкласса, кв. км 
площади 5577,0 кв. км (3,5\% от площади края) распространен широколиственно-кедровый лесной на горно-лесных бурых почвах вид ландшафтов. Близок к нему по площади вид пихтовоелово-лиственично-мелколиственный лесной на горно-лесных бурых почвах, занимающий 5048,0 кв. км, $3,1 \%$ от площади края. Менее развит на площади 3108 кв. км, занимающий 1,9\% площади края, вид мелколиственный лесной по гарям на горнолесных почвах.

По распространенности видов ландшафтов все остальные, в частности смешанных широколиственно-мелколиственныых лесов на горно-лесных бурых почвах, широколиственных лесов на горно-лесных бурых почвах и др., занимают площади от 21 до 1586 кв. км, что составляет соответственно 0,01 до 1,0\% края. Анализ картографо-статистических данных по дифференциации видов ландшафтов в целом по массивно-среднегорному полисубстратному роду показывает, что по распространенности виды ландшафтов дифференцируются в ряд от доминантных к редким: широколиственно-кедрово-еловый, широколиственно-кедровый, мелколиственный по гарям, пихтово-елово-лиственнично-мелколиственный, дубовый, широколиственный, широколиственно-мелколиственный, лиственнично-хвойно-смешанный, невозобновившихся молодых гарей, грабово-широколиственный, грабово-чернопихтово - широколиственный.

Низкогорный терригенный род ландшафтов Приморского края дифференцирован на 14 видов ландшафтов. Доминантный на территории низкогорного терригенного рода ландшафтов широколиственно-кедровый на горно-лесных бурых почвах вид с площадью 14507,0 кв. км (рис. 58), занимающий 9,0\% от площади края. Характерный развит на площади 10379,0 кв. км $(6,4 \%$ от площади края) дубовый лесной на горно-лесных бурых почвах вид ландшафтов. Близок по распространенности к предыдущему виду широколиственно-кедрово-еловый лесной на горно-лесных бурых почвах вид, занимающий 7404,0 кв. км, составляющий 4,6\% от площади края. Менее развит на площади 5167,0 кв. км, занимающий $3,2 \%$ площади края лесной широколиственный с липами, кленом и дубом на горно-лесных почвах вид. Меньше предыдущего вида развит лесной грабово-широколиственный. Он занимает площадь 2692 кв. км, или 1,7\% от площади края. В модели распространенности видов ландшафтов все остальные, в частности лесной широколиственно-мелколиственный на горно-лесных бурых почвах, лесной широколиственный с липами,

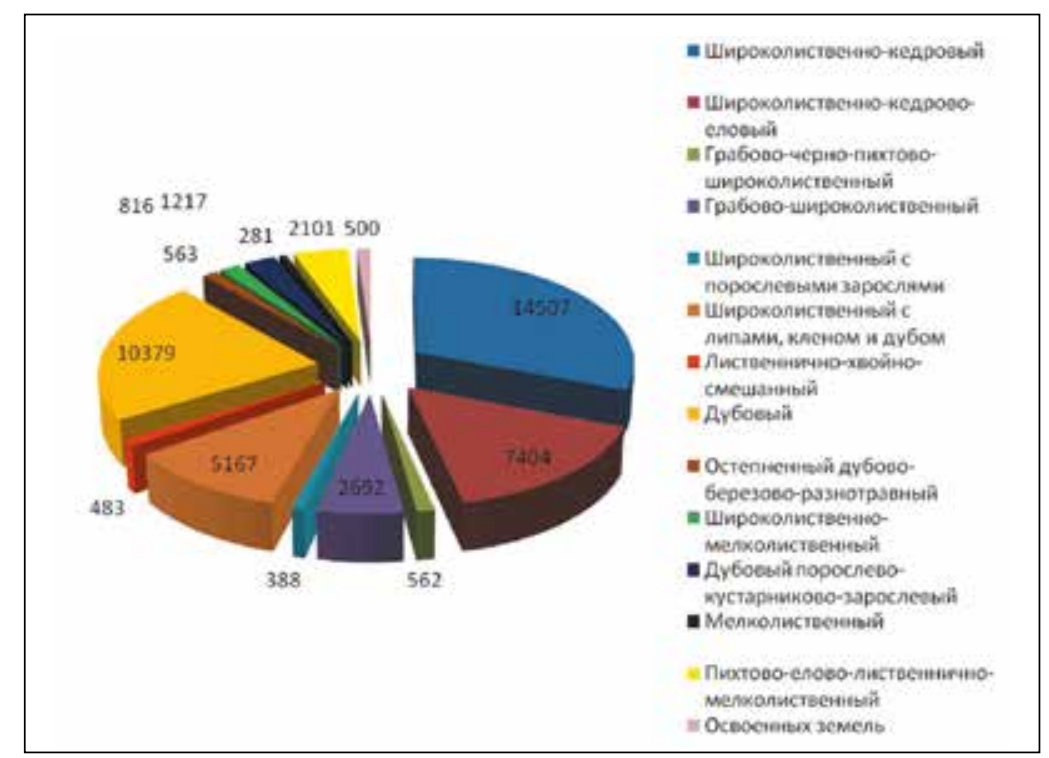

Puc. 58. Виды ландшафтов низкогорного терригенного рода горнолесного смешанно-широколиственного подкласса, кв. км

кленом и дубом на горно-лесных бурых почвах и др., занимают плошади от 281 до 2101 кв. км, что составляет соответственно от 0,2 до $1,3 \%$ площади края.

Анализ картографо-статистических данных по дифференциации видов ландшафтов в целом по низкогорному терригенному роду показывает, что по распространенности лесные виды ландшафтов дифференцируются в ряд (от доминантных к редким): широколиственно-кедровый, дубовый, широколиственно-кедрово-еловый, широколиственный с липами, кленом и дубом, грабово-широколиственный, пихтово-елово-лиственнично-мелколиственный, дубовый порослево-кустарниково-зарослевый, широколиственно-мелколиственный, остепненный дубово-березово-разнотравный, грабово-чернопихтово-широколиственный, освоенных земель, лиственнично-хвойно-смешанный, широколиственный с порослевыми зарослями, мелколиственный.

Платобазальтовый род ландшафтов Приморского края дифференцирован на 12 видов ландшафтов. Доминантный на территории платобазальтового рода ландшафтов пихтово-елово-лиственнично-мелколиственный лесной на горно-таежных бурых почвах вид с площадью 2617,0 кв. км (рис. 59), занимающий 


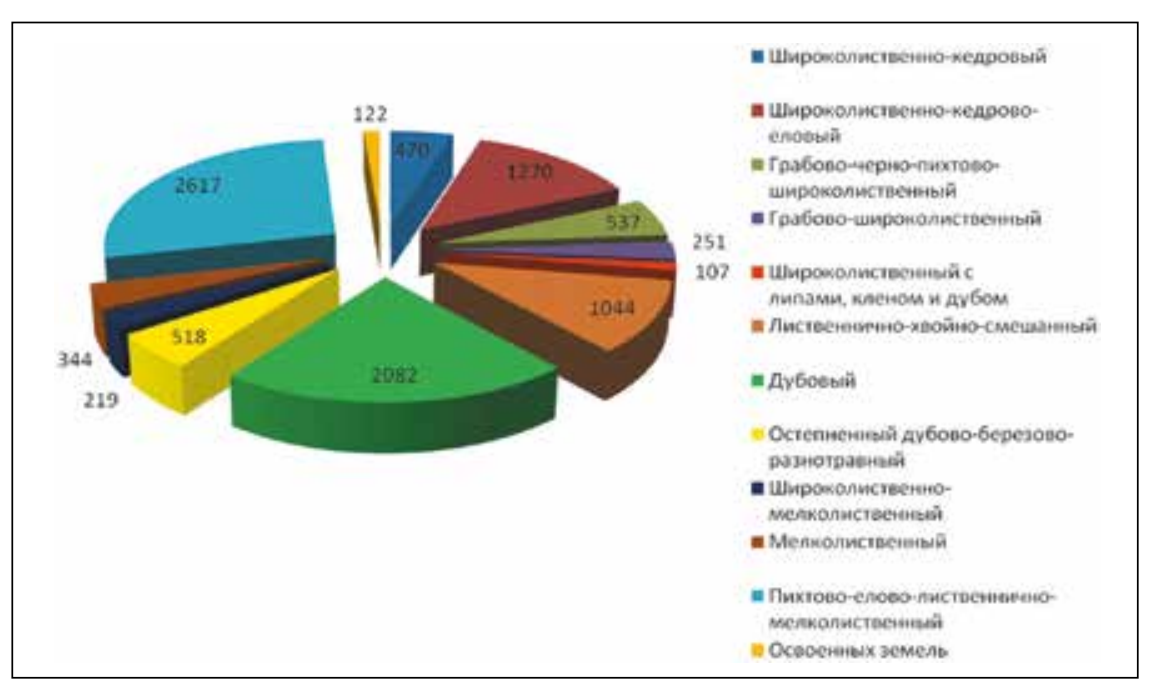

Puc. 59. Виды ландшафтов платобазальтового рода горно-лесного смешанно-широколиственного подкласса, кв. км

$1,6 \%$ от площади края. На площади 2082 кв. км (1,1\% от площади края) дубовый лес на горно-лесных бурых почвах вид ландшафтов. Характерный развит на площади 1270 кв. км, занимающий $0,8 \%$ площади края, широколиственно-кедрово-еловый лесной на горно-таежных, реже горно-лесных, почвах вид. По распространенности видов ландшафтов все остальные, в частности грабово-широколиственный на горно-лесных бурых почвах, широколиственный на горно-лесных бурых почвах, мелколиственный на горно-лесных бурых почвах и др., занимают площади от 107 до 1044 кв. км, что составляет соответственно 0,07 до $0,6 \%$ площади края. Анализ картографо-статистических данных в целом по массивно-среднегорному роду показывает, что по распространенности виды ландшафтов дифференцируются в ряд (от доминантных к редким): пихтово-елово-лиственничномелколиственный, дубовый, широколиственно-кедрово-еловый, лиственнично-хвойно-смешанный, грабово-широколиственный, широколиственный, остепненный дубово-березовый разнотравный, широколиственно-кедровый, мелколиственный, широколиственно-мелколиственный, освоенных земель, широколиственный с липами, кленом и дубом.

Мелкосопочный полисубстратный род ландшафтов Приморского края включает 5 видов ландшафтов. Доминантный на тер- ритории мелкосопочного полисубстратного рода ландшафтов остепненный дубово-березовый разнотравный на горно-лесных бурых, бурых, лугово-бурых почвах лесной вид с площадью 1626,0 кв. км, занимающий $1,0 \%$ от площади края. На площади 1293 кв. км (0,8\% от площади края) распространены освоенные земли на месте луговых степей и остепненных лугов на бурых почвах, которые тоже имеют ранг вида ландшафтов. Менее развит на площади 942 кв. км, занимающий $0,6 \%$ площади края дубовый лес на горно-лесных почвах.

Анализ картографо-статистических данных по распространенности видов (как и др. таксонов) ландшафтов в целом по территориям показывает, что по распространенности виды ландшафтов дифференцируются в ряды, анализ которых имеет особое значение для природоохранных целей.

Площадное пространственное распределение ландшафтов и результаты установленных статистических количественных закономерностей для территории Приморского края установлены кроме приведенных выше примеров для всех рангов ландшафтов (количественные закономерности данных по площадям подклассов, родов, видов и местностей, их процентным соотношениям опубликованы [232, 243]).

В результате статистисческих исследований также установлено, что виды ландшафтов Приморья характеризуются цифровыми данными:

1. Суммарная площадь контуров - 161737, 2 кв. км

2. Количество контуров -93 шт.

3. Средняя площадь контуров - 1739, 1 кв. км

4. Ландшафтная сложность $-\mathrm{K}=0,05$

5. Ландшафтная раздробленность $-\mathrm{K}=0,01$

6. Показатель упорядоченности структуры - 0,85 усл. ед.

7. Максимальная энтропия - 11, 545 усл. ед.

8. Энтропийная мера общего разнообразия $-1,716$ усл. ед.

9. Энтропийная мера неуравновешенности ландшафтной структуры - 9, 829 усл. ед.

Анализ ландшафтных особенностей по группам пространственных и морфологических данных. Ниже на примере картографо-статистических данных по видам ландшафтов рассматриваются пространственная и морфологическая дифференциация и результаты установленных статистических количественных особенностей ландшафтов для территории Приморского края. 
По группе пространственных данных получены данные характеризующие прежде всего расположение исследуемых ландшафтов на земном шаре. Даны их географические координаты - широта и долгота, охарактеризованы крутизна склонов, удаление от моря, а также средние и максимальные высоты (табл. 15).

Анализируя полученные данные по отмеченным выше характеристикам ландшафтных геосистем на основе конкретных статистических данных/, например по удаленности от морских акваторий, мы пришли к выводу, что рассматриваемые в работе геосистемы относятся по ландшафтной континентально-океанической дихотомии [9] к особым, ранее в ландшафтной географии Приморья не выделяемым, окраинно-континентальным горным геосистемам. Они удалены от морских акваторий в среднем до

Таблица 15

Пространственные характеристики исследуемых видов ландшафтов Приморья (фрагмент)

\begin{tabular}{|c|c|c|c|c|c|}
\hline \multirow{2}{*}{$\begin{array}{c}\text { Номер } \\
\text { вида лан- }\end{array}$} & \multicolumn{2}{|c|}{$\begin{array}{c}\text { Географические коор- } \\
\text { дшнаты }\end{array}$} & \multicolumn{2}{|c|}{ Высота в метрах } & Средняя \\
\cline { 2 - 5 } по карте & долен- & & Средняя \\
полгта & Широта & $\begin{array}{c}\text { Сред- } \\
\text { макси- } \\
\text { мальная }\end{array}$ & $\begin{array}{c}\text { няя } \\
\text { высота }\end{array}$ & $\begin{array}{c}\text { ность от } \\
\text { моря, км }\end{array}$ \\
\hline 1 & 136,7910 & 46,2949 & 1319,5 & 1068,9 & 78,550 \\
2 & 135,1537 & 44,9839 & 1289,0 & 901,8 & 79,904 \\
3 & 135,8445 & 45,5645 & 1147,4 & 774,1 & 84,540 \\
4 & 136,3349 & 46,0898 & 870,0 & 629,2 & 86,257 \\
5 & 136,4674 & 46,1973 & 928,3 & 715,6 & 76,869 \\
6 & 134,0639 & 44,2812 & 842,0 & 539,5 & 93,661 \\
7 & 134,5954 & 44,4200 & 1039,9 & 702,1 & 76,122 \\
8 & 133,6714 & 43,9954 & 775,5 & 485,1 & 72,168 \\
9 & 132,9579 & 43,2115 & 701,6 & 387,7 & 29,103 \\
10 & 135,3384 & 44,2332 & 603,3 & 353,5 & 26,026 \\
11 & 137,0068 & 46,7935 & 1525,0 & 854,5 & 97,455 \\
12 & 135,0508 & 44,0344 & 827,8 & 455,4 & 22,951 \\
13 & 136,7853 & 46,2752 & 1376,8 & 983,5 & 72,147 \\
14 & 134,6979 & 43,9482 & 1126,8 & 769,4 & 44,718 \\
15 & 135,5656 & 44,7430 & 859,5 & 666,6 & 44,744 \\
16 & 137,2242 & 46,3555 & 1173,4 & 668,4 & 45,080 \\
17 & 135,4402 & 44,6568 & 1181,0 & 807,3 & 46,472 \\
18 & 134,9774 & 44,7601 & 848,6 & 547,0 & 82,264 \\
19 & 135,3221 & 45,1749 & 964,8 & 638,7 & 90,044 \\
20 & 135,7504 & 45,7918 & 822,5 & 542,9 & 105,456 \\
\hline
\end{tabular}

100 км (табл. 15), тогда как внутриконтинентальные геосистемы, например Баргузинский хребет Байкальской геосистемы удален от морей на 1520 км [157]. Предлагается ландшафтные геосистемы Приморья рассматривать и выделять их как окраинно-континентальные горные ландшафтные геосистемы.

Ландшафтные геосистемы характеризуются не только пространственными, но и морфологическими характеристиками по крутизне склонов, по горизонтальному и вертикальному их расчленению и др. (табл. 16). Полученные впервые данные характеризуют природную специфику и индивидуальность рассматриваемых ландшафтов, сложную их организационную структуру. Цифровые характеристики, несмотря на условность этих параметров в приложении к поликомпонентным комплексам позволяют целостнее представлять ландшафт.

Таблица 16

Морфологические характеристики видов ландшафтов

\begin{tabular}{|c|c|c|c|c|}
\hline $\begin{array}{c}\text { Номер вида } \\
\text { ландшафта } \\
\text { по карте }\end{array}$ & $\begin{array}{c}\text { Средняя } \\
\text { амплиту- } \\
\text { да высот } \\
\text { в м }\end{array}$ & $\begin{array}{c}\text { Средняя } \\
\text { крутизна } \\
\text { склонов, } \\
\text { град }\end{array}$ & $\begin{array}{c}\text { Среднее го- } \\
\text { ризонтальное } \\
\text { расчленение, } \\
\text { км/кв км }\end{array}$ & $\begin{array}{c}\text { Среднее } \\
\text { вертикаль- } \\
\text { ное расчле- } \\
\text { нение, } \\
\text { км/кв.км }\end{array}$ \\
\hline 1 & 542,8 & 18,8 & 0,0706 & 0,7038 \\
2 & 711,6 & 15,9 & 0,0939 & 0,2365 \\
3 & 685,1 & 16,3 & 0,1057 & 0,2546 \\
4 & 426,0 & 11,5 & 0,1134 & 0,2151 \\
5 & 512,0 & 9,3 & 0,0739 & 0,1842 \\
6 & 514,6 & 13,1 & 0,1175 & 0,2560 \\
7 & 595,9 & 14,1 & 0,1073 & 0,2149 \\
8 & 503,8 & 11,6 & 0,0265 & 0,0985 \\
9 & 483,3 & 12,7 & 0,2047 & 0,2836 \\
10 & 459,0 & 13,3 & 0,1464 & 0,1743 \\
11 & 1020,0 & 13,7 & 0,0159 & 0,0668 \\
12 & 629,4 & 16,1 & 0,1177 & 0,3109 \\
13 & 701,0 & 17,0 & 0,0960 & 0,2143 \\
14 & 666,9 & 16,5 & 0,0899 & 0,2960 \\
15 & 370,5 & 9,2 & 0,0790 & 0,1583 \\
16 & 903,6 & 19,3 & 0,0951 & 0,1785 \\
17 & 639,0 & 13,7 & 0,0597 & 0,1794 \\
18 & 517,7 & 14,5 & 0,0775 & 0,2458 \\
19 & 565,8 & 15,0 & 0,1159 & 0,2274 \\
20 & 455,0 & 14,1 & 0,0000 & 0,4540 \\
\hline & & & & \\
\hline
\end{tabular}


Их получение способствует накоплению количественных характеристик в ландшафтной географии Приморья и расширяет возможности использования определенных параметров при техногенных воздействиях и природоохранно-экологических мероприятях. При их решении важно знать первичную базу, начальную точку нарушения и в этом случае полученные числовые данные рассматриваются как базовые.

Изучение пространственных и структурно-морфологических данных, характеризующих определенную ландшафтную единицу, ландшафтный выдел, обычно проводится корреляционным анализом. Корреляционная связь между структурными единицами имеет различную степень - от почти полной независимости, до очень тесной связи. По числу статистически значимых связей можно судить о главных и второстепенных факторах, значимых и не очень и, используя главные из них, сравнивать разные ландшафтные геосистемы.

Перечень количественных факторов, используемых в корреляционном анализе, приведен в табл. 17. Значения парных коэффициентов корреляции представлены в табл. 18.

Статистически значимые коэффициенты корреляции подчеркнуты. После удаления зависимостей, вытекающих одной из другой, выявлены статистически значимые связи.

Следует отметить, что в практике Российского ландшафтоведения, ранее применялись для подсчетов данные по крупным планетарно- региональным объектам, например, таким как мощные горные системы. В частности, проводилось цифровое сравнение ландшафтных структур гор Прибайкалья с некоторыми горны-

Таблица 17

Количественные факторы

\begin{tabular}{|c|l|c|}
\hline $\begin{array}{c}\text { Номер } \\
\text { фактора }\end{array}$ & \multicolumn{1}{|c|}{ Наименование фактора } & $\begin{array}{c}\text { Ед. измере- } \\
\text { ния }\end{array}$ \\
\hline 1. & Анализируемая площадь & кв. км \\
2. & Горизонтальное расчленение & км / кв. км \\
3. & Вертикальное расчленение & км / кв. км \\
4. & Максимальная высота & м \\
5. & Амплитуда высот & м \\
6. & Средняя высота & м \\
7. & Удаленность от моря & км \\
8. & Крутизна склонов & град. \\
\hline
\end{tabular}

214
Матрица коэффициентов парной корреляции количественных факторов

\begin{tabular}{|c|c|c|c|c|c|c|c|}
\hline 1,00 & & & & & & & \\
\hline 0,05 & 1,00 & & & & & & \\
\hline$-0,36$ & $-0,20$ & 1,00 & & & & & \\
\hline 0,28 & $-0,26$ & 0,43 & 1,00 & & & & \\
\hline 0,35 & $-0,28$ & 0,36 & 0,93 & 1,00 & & & \\
\hline 0,22 & $-0,29$ & 0,47 & 0,97 & 0,84 & 1,00 & & \\
\hline 0,09 & 0,16 & $-0,31$ & $-0,28$ & $-0,40$ & $-0,21$ & 1,00 & \\
\hline 0,11 & $-0,38$ & 0,56 & 0,88 & 0,92 & 0,82 & $-0,42$ & 1,00 \\
\hline
\end{tabular}

ми геосистемами Азии, ландшафтных структур юга Восточной Сибири [143]. Сравнивались и отдельные горные хребты [157]. В предлагаемой читателю работе объект сравнения - выделы ландшафтов масштаба 1: 500000 (подкласс, род, вид, местность). В результате сравнения цифровых данных корреляционного анализа на примере видов ландшафтов выявлены особенности структуры ландшафтов Приморья. Такие факторы, как анализируемая площадь, горизонтальное и вертикальное расчленение, максимальная высота, удаленность от моря, энтропийная мера неуравновешенности ландшафтной структуры не связаны с другими факторами, в том числе и ландшафтными.

Наибольщим «статистическим весом» (по количеству статистически значимых связей) обладают такие факторы как средняя высота, амплитуда высот, крутизна склонов. Анализом полученных значимых корреляционных связей и пространственной распространенности видов ландшафтов устанавливается прямая связь распространенности видов от крутизны и высоты. Устанавливается высотная поясность. С увеличением высоты горно-лесной смешанно-широколиственный пояс сменяется горно-темнохвойным, а затем горно-тундровым. Кроме того, прямые корреляционные связи с вариациями высот подчеркивают наличие изменения высотных уровней: низкогорного, среднегорного и высокогорного.

По статистическим пространственным и морфологическим данным ландшафтные иерархические единицы имеют индивидуальные особенности. 
Итак, в результате картографо-статистического изучения и анализа ландшафтов и их пространственной дифференциации в масштабе 1: 500000 впервые в рамках ландшафтной географии для всех картографированных выделов ландшафтов Приморского края установлены статистические данные и закономерности:

1) площади;

2) суммарная площадь;

3) количество выделов;

4) средняя площадь;

5) горизонтальное расчленение;

6) вертикальное расчленение:

7) максимальная высота;

8) амплитуда высот;

9) средняя высота;

10) удаленность от моря;

11) крутизна склонов;

12) ландшафтная сложность;

13) ландшафтная раздробленность;

14) показатель упорядоченности структуры;

15) максимальная энтропия;

16) энтропийная мера общего разнообразия;

17) энтропийная мера неуравновешенности ландшафтной структуры;

18) количественное структурное, площадное и процентное соотношение подклассов, родов, видов и местностей;

19) количественная пространственно-площадная дифференциация ландшафтов Приморского края;

20) составлен банк данных площадей и процентных соотношений в соответствии с классификационными уровнями ландшафтов и их структурами.

На основе анализа ландшафтной карты Приморского края установлены статистические, площадные (количественные) ландшафтные закономерности:

1) среди подклассов ландшафтов доминантные ландшафты горно-лесного смешанно-широколиственного и лесостепного равнинного и долинно-речного подклассов, характерные ландшафты горно-темнохвойного подкласса, редкие горно-тундровые;

2) среди категории род ландшафтов доминантные ландшафты низкогорного терригенного, редкие ландшафты гольцового полисубстратного рода;
3) в горно-темнохвойном подклассе доминантные ландшафты расчленено-среднегорного полисубстратного рода, за ними следуют массивно-среднегорный полисубстратный, редкие ландшафты низкогорного вулканогенно-терригенного рода

4) в горно-лесном смешанно-широколиственном подклассе доминантные ландшафты низкогорного терригенного рода, за ними по распространенности следуют расчленено-среднегорные полисубстратные, редкие мелкосопочные полисубстратные, к расчленено-среднегорным близки платобазальтовые;

5) в лесостепном равнинном и долинно-речном подклассе доминантные ландшафты эрозионно-аккумулятивно-равнинного и долинно-речного рода;

6) среди видов ландшафтов низкогорного терригенного рода доминантные широколиственно-кедровые и кедровые на горнолесных бурых почвах ландшафты, а также горно-темнохвойного подкласса расчленено-среднегорного полисубстратного рода с видом ландшафтов пихтово-еловых лесов на горно-таежных бурых почвах. Характерен вид ландшафтов с дубовыми лесами, их редколесьями и порослевыми зарослями на горно-бурых почвах. редкий вид дубовых лесов приморско- равнинного рода.

7) Виды ландшафтов закономерно увязаны с родами и дифференцированы по родам подклассов ландшафтов: горно-темнохвойному, горно-лесному смешанно-широколиственному, лесостепному равнинному и долинно-речному. В подклассах ландшафты также закономерно дифференцированы по площадям по родам ландшафтов: массивно-среднегорному полисубстратному, расчленено-среднегорному полисубстратному, низкогорному терригенному, платобазальтовому и др.

8) Установлена пространственная горизонтальная и высотная (площадная) дифференциация местностей по видам, родам, подклассам ландшафтов Приморского края.

9) Все данные по площадям и количественным соотношениям по выделенным в работе таксонам опубликованы в объяснительной записке к карте ландшафтов Приморского края [300, 301].

10) Полученные статистические материалы и анализ пространственного распределения ландшафтов используются для обоснования выделения окраинно-континентальной геосистемы, ландшафтной поясности и высотных уровней.

Полученные в рамках ландшафтной географии данные как база статистического анализа и установленные при его проведении закономерности пространственной дифференциации ландшафтов 
составляют не только часть теории регионального ландшафтоведения. Заложены основы их многоцелевого использования, в том числе при решении природоохранно-экологических проблем, задач ландшафтной географии в цифровом (статистическом) поле геосистем регионов.

\section{Контрольные вопросы}

1. Раскройте содержание фактического материала, использованного для статистической обработки ландшафтной карты Приморья.

2. Охарактеризуйте группы количественных характеристик снимаемых с карты ландшафтов Притморья.

3. Охарактеризуйте группу пространственных количественных данных ландшафтов.

4. Охарактеризуйте группу морфологических количественных данных ландшафтов.

5. Охарактеризуйте группу ландшафтных количественных данных ландшафтов.

6. Раскройте закономерности дифференциации ландшафтов по группе ландшафтных данных.

7. Раскройте полученные индивидуальные статистические данные по видам ландшафтов Приморья.

8. Раскройте ландшафтные особенности по группе пространственных данных.

9. Раскройте ландшафтные особенности по группе морфологических данных.

10. Перечислите и дайте характеристику индивидуальных статистических особенностей ландшафтных таксонов Приморья.

11. Охарактеризуйте установленные на основе ландшафтной карты Приморья статистические (площадные) ландшафтные закономерности.

12. Раскройте возможности статистического синтеза и анализа для целей моделирования географического пространства в области ландшафтной географии.

\section{Лекщия 13}

ЛАНДШАФТНЫЙ АНАЛИЗ И СИНТЕЗ КАК ОСНОВА КОМПЛЕКСНОЙ ОЦЕНКИ АНТРОПОГЕННЫХ ПРЕОБРАЗОВАНИЙ ПРИРОДЫ ПРИМОРЬЯ

(на примере угольного и горнорудного производства)

Методические и методологические подходы к изучению экологического состояния ландшафтов рассматриваются в литературе достаточно широко (лекция 3). При этом, как показывает практика, наиболее приемлемыми для исследований регионального масштаба являются ландшафтные материалы и карты масштаба 1: $500000,1: 1000000$. В работе при разработке практических приложений ландшафтного подхода к решению экологических проблем и ситуаций (в трактовке Б.И. Кочурова [107]) территорий угольного и горно-рудного производства в качестве основ используются разработанные и составленные нами оцифрованные ландшафтные карты Приморского края масштабов 1: 500000 и 1: 1000000 [232, 243, 244]. Для этого прежде всего необходимо установить ландшафтный статус региональных центров угольного и горно-рудного производства. При этом под ландшафтным статусом нами понимается ландшафтно-компонентная специфика территорий минерально-сырьевого освоения, испытывающих техногенные трансформации в пространстве разноранговых динамических геосистем Приморья.

\section{Ландшафтный статус промышленных угольных и горно-}

рудных центров минерально-сырьевого производства

Территория Приморского края богата месторождениями полезных ископаемых. Они группируются в промышленные угольные и горно-рудные центры [38]. Наиболее крупные из них: угольные - Артемовский, Партизанский, Павловский, Лучегорский; вольфрамовый - Восток; оловодобывающий - Кавалеровский; 
полиметаллический - Дальнегорский. В регионе они занимают определенное место как в иерархии природных ландшафтов, так и в географическом пространстве физико-географических областей, провинций и округов. Их ландшафтный статус установлен нами по результатам ландшафтного районирования и исследований по пространственному размещению промышленных территорий (табл. 19, [260, 257]).

Центры расположены в равнинном и горном классах ландшафтов [243]. В равнинном классе ландшафтов, представленном эрозионно-аккумулятивно-равнинным и долинно-речным родами, расположены Павловский и Лучегорский угольные разрезы. В отличие от них Партизанский, Кавалеровский, Дальнегорский и др. функционируют в условиях горного класса ландшафтов, представленных горно-темнохвойным, горно-лесным смешанно-широколиственным подклассами, массивно-среднегорным и расчленено-среднегорным полисубстратными, низкогорным терригенным родами.

Ландшафтный статус территорий локальных угольных и рудных центров и месторождений определяется также структурной дифференциацией ландшафтов на региональном уровне, прежде всего в ландшафтных провинциях [251, 257,261] (рис. 60).

Павловский и Лучегорский угольные разрезы расположены в Уссури-Ханкайской провинции, охватывающей бассейны рек Мельгуновка, Комиссаровка, Илистая, Белая, среднее течение p. Уссури, нижнее течение р. Большая Уссурка и др. Центральная ее часть - Приханкайская низменность. На территории провинции развиты ландшафты равнинного класса, лесостепного равнинного и долинно-речного подкласса, эрозионно-аккумулятивно- равнинного и долинно-речного рода, различных лесных видов с широколиственно-мелколиственно-смешанными, долинными широколиственными с липами, кленом и дубом, редколесно-порослево-дубовых, мелколиственных вейниково-осоковых, луговых осоко-вейниковых на лугово-бурых, бурых лесных, задернованных дерново-торфянисто-глеевых, луговых пойменных и болотных почвах. Доминантными являются местности с четвертичными аллювиально-озерными (мощность от 1,0 до 60 м) и гранитоидными, сланцевым, карбонатно-гнейсовым и другими комплексами фундамента.

Такие месторождения, как Партизанское и Артемовское расположены в Южно-Приморской провинции, расположеной в южной части Приморского края. Территория провинции харак-

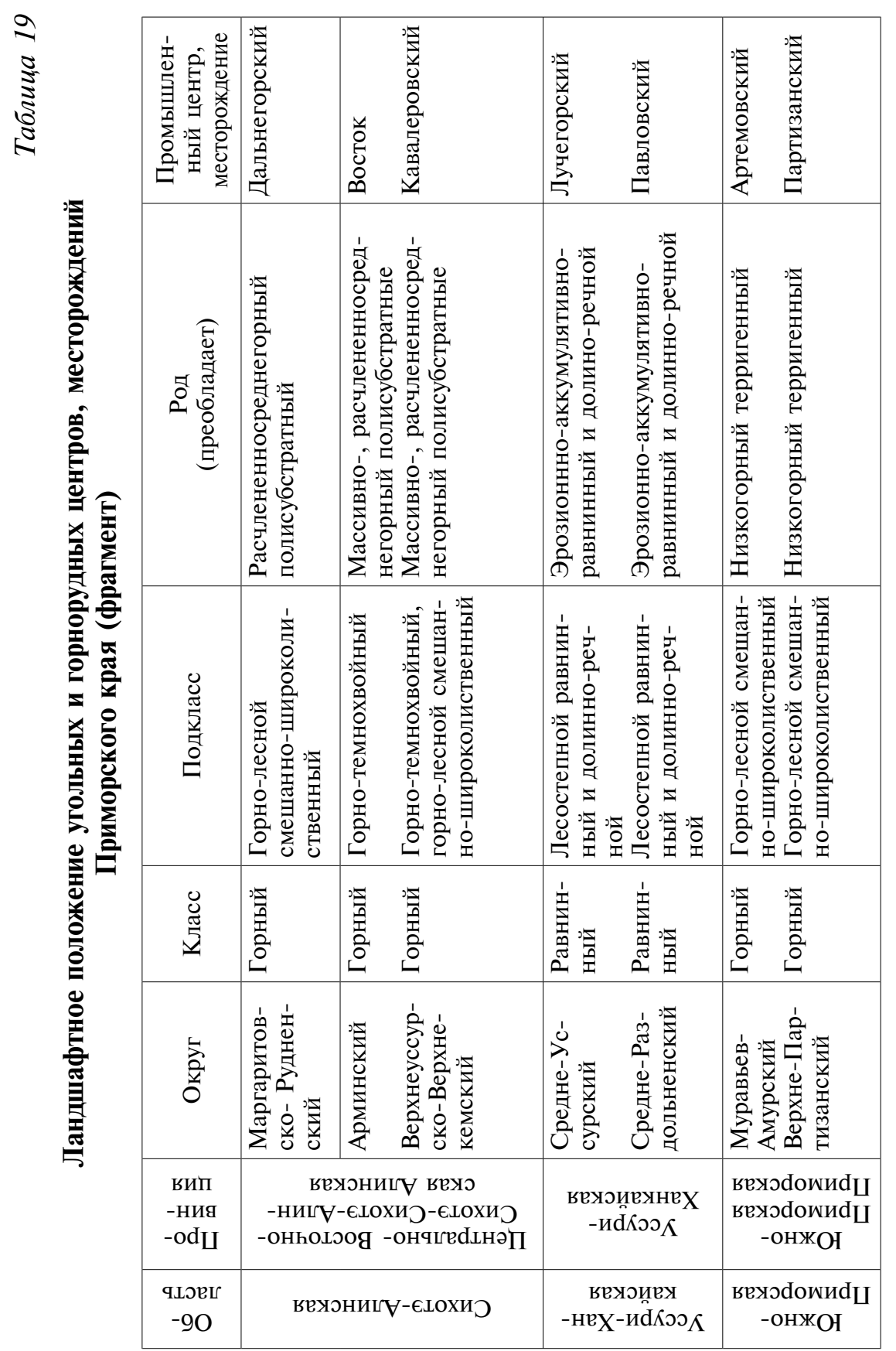




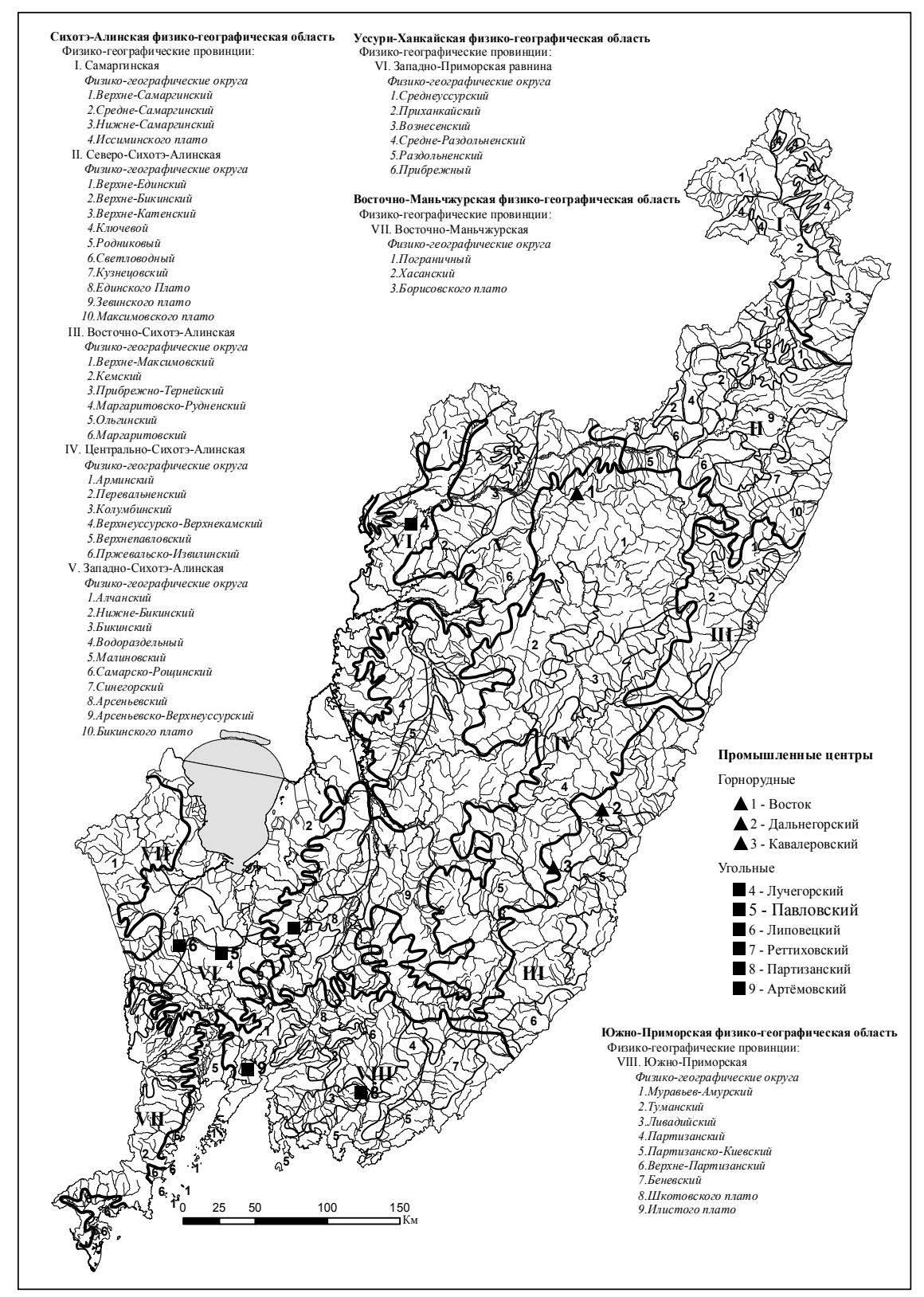

Puc. 60. Карта физико-географического районирования и положения некоторых промышленных угольных и горнорудных центров минерально-сырьевого производства теризуется сочетанием ландшафтов горно-темнохвойного, горнолесного смешанно-широколиственного, лесостепного равнинного и долинно-речного подклассов и расчленено-среднегорных полисубстратных, низкогорных терригенных и эррозионно- аккумулятивных равнинных и долинно-речных ландшафтных родов, равнинных видов с вейниково-осоковыми, осоковыми и другими растительными равнинными группировками на лугово-дерновых, лугово-глеевых и других почвах, видов ландшафтов с хвойными, широколиственными и смешанными лесами на различных бурых лесных и других почвах. На картах здесь показаны местности с метагабброидным, алевролит-песчаниковым, песчаниково-карбонатно-алевролитовым, гранитоидным и другими вещественными комплексами фундамента.

Месторождения рудных центров Кавалеровское и Восток расположены в Центрально-Сихотэ-Алинской провинции, охватывающей наиболее возвышенную часть горной страны Сихотэ-Алиня от хр. Боголадза на севере до хр. Пржевальского на юге включительно. Она включает горно-тундровый полисубстратный, горно-темнохвойный, горно-лесной смешанношироколист-венный подклассы, гольцовый полисубстратный, массивно- и среднегорнорасчлененный полисубстратные роды ландшафтов, различные виды с гольцовыми и подгольцовыми, пихтово-еловыми, кедрово-широколиственными и широколиственными лесами на горно-тундровых, горно-таежных и горно-лесных бурых и других почвах. Распространены местности с алевролит-песчаниковым, песчаниково-алев-ролитовым, кремнисто-глинистым, интрузивным кислого состава вещественными комплексами фундамента.

Дальнегорский рудный центр расположен в Восточно-СихотэАлинской провинции. Территория провинции характеризуется сочетанием ландшафтов различных видов и местностей. В северной части территории провинции на вершинах с высотами 1200-1250 м развиты ландшафты горно-тундрового подкласса, гольцового полисубстратногоого рода и видов с комплексом лишайниково-кустарниковых и травянистых группировок, стелющимися лесами на горно-тундровых иллювиально-гумусовых и дерново-органических почвах. В среднегорном высотном уровне развиты ландшафты преимущественно горно-лесного смешанно-широколиственного подкласса, среднегорнорасчлененного полисубстратного и низкогорного терригенного родов и видов с зарослями низкорослых ельников, каменноберезников и лист- 
веничников. Развиты местности с вулканитовым и интрузивным вещественными комплексами различного петрографического состава и, реже, песчаниково-алевролитово-известняково-кремнистым вещественным комплексом фундамента.

В результате исследования структуры ландшафтов и положения в них угольных и горно-рудных центров Приморского края также установлено определенное ландшафтное место центров минерально-сырьевого производства во всех рассматриваемых в лекциях иерархических единицах ландшафтов (местностях, видах, родах, подклассах и классах) (рис. 61).

\section{Контрольные вопросы}

1. Раскройте понятие основы установления ландшафтного статуса.

2. Раскройте понятие ландшафтного статуса объектов производства.

3. Охарактеризуйте наиболее крупные угольные и горнорудные центры Приморского края.

4. Охарактеризуйте распределение центров угольного и горнорудного производства по классам ландшафтов.

5. Охарактеризуйте ландшафтное положение центров угольного и горнорудного производства в провинциях ландшафтов Приморья.

6. Раскройте внутреннее содержание Уссури-Ханкайскпй провинции и расположенных в ней угольных центров.

7. Раскройте внутреннее содержание Южно-Приморской провинции и расположенных в ней угольных центров.

8. Охарактеризуйте внутреннее содержание Центрально-Сихотэ-Алинской провинции и расположенных в ней горнорудных центров.

9. Раскройте внутреннее содержание Восточно-Сихотэ-Алинской провинции и расположенных в ней горнорудных центров.

10. Раскройте возможности получения ландшафтной информации по любым объектам природопользования на примере угольного и горнорудного производства.

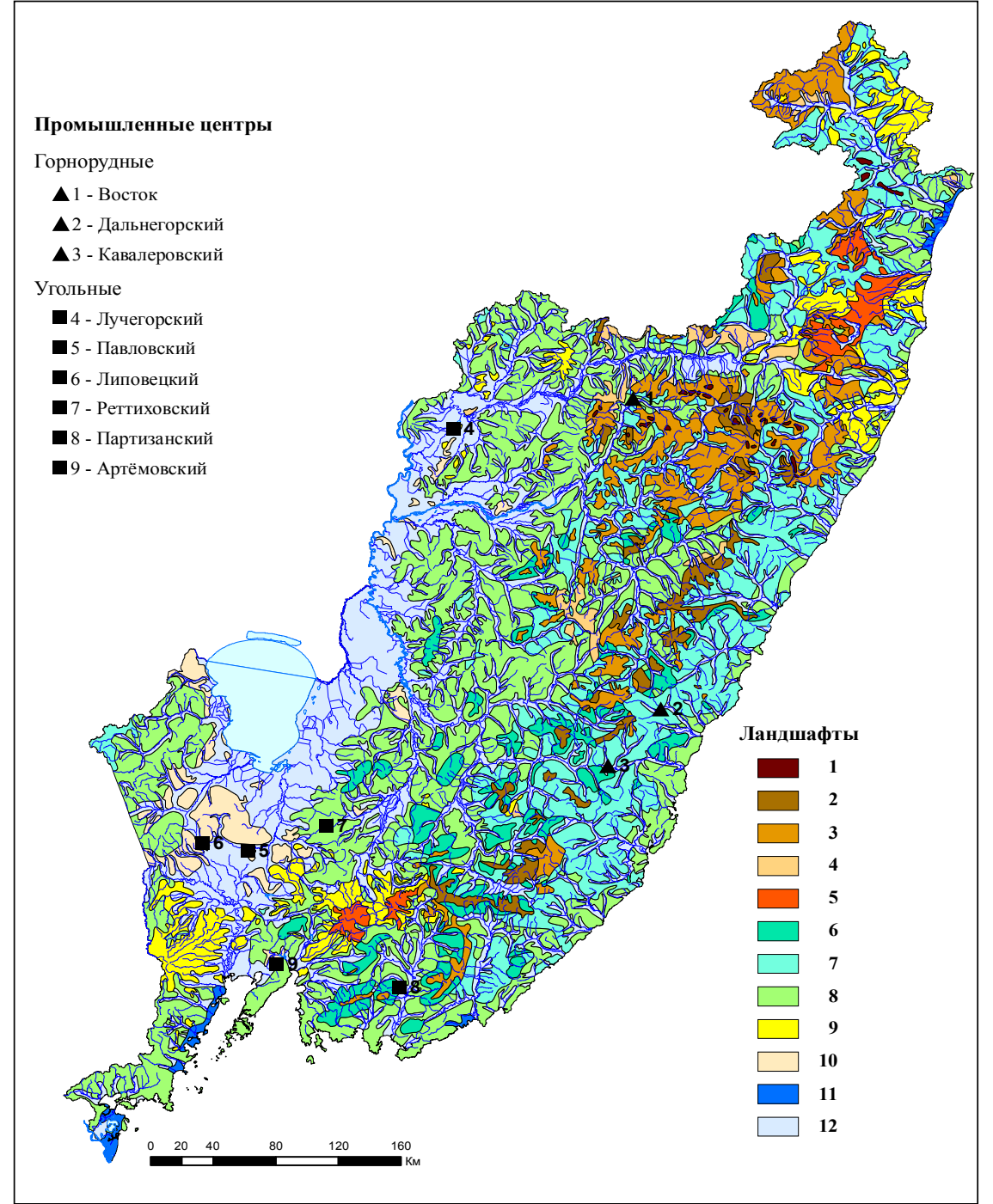

Рuc. 61. Карта ландшафтов Приморского края и расположения некоторых угольных и горнорудных центров: 1-12 - номера ландшафтов

Горно-тундровые

1. Горно-тундровые с гольцовыми полисубстратными стланиковыми лишайниково-кустарниковыми, травянистыми группировками на горно-тундровых почвах. 
2. Горно-темнохвойные массивносреднегорные полисубстратные с пихтово-еловыми лесами на горно-таежных бурых почвах;

3. Горно-темнохвойные расчленено-среднегорные полисубстратные с пихтово-еловыми лесами на горно-таежных бурых почвах;

4. Горно-темнохвойные низкогорные вулканогенно-терригенные с пихтово-еловыми лесами на горно-таежных бурых почвах;

5. Горно-темнохвойные платобазальтовые с пихтово-еловыми лесами на горно-таежных бурых почвах;

Горно-лесные смешанно-широколиственные

6. Горно-лесные смешанно-широколиственные массивно-среднегорные полисубстратные с широколиственными лесами на лесных бурых почвах;

7. Горно-лесные смешанно-широколиственные расчленено-среднегорные полисубстратные с широколиственными лесами на лесных бурых и других почвах;

8. Горно-лесные смешанно-широколиственные низкогорные терригенные со смешанными, широколиственными лесами на лесных бурых почвах;

9. Горно-лесные смешанно-широколиственные платобазальтовые с ши9. Горно-лесные смешанно-широколиственные платобазальтовые с ши-
роколиственно-кедровыми, широколиственными лесами на горно-таежных бурых почвах;

10. Горно-лесные смешанно-широколиственные мелкосопочные полисубстратные с дубовыми, дубово-лещинно-леспедециевыми луговыми группировками на горно-лесных бурых, лугово-бурых почвах;

Лесостепные равнинные и долинно-речные

11. Лесостепные приморско-равнинные с типичными вейниково-осоковыми и другими группировками с участками широколиственных лесов и сельскохозяйственных земель на бурых лесных, торфяно-глеевых и других почвах;

12. Лесостепные равнинные и долинно-речные эрозионно-аккумулятивные с типичными вейниково-осоковыми и другими группировками с участками широколиственных лесов и сельскохозяйственных земель на бурых лесных, торфяно-глеевых и других почвах.

\section{Лекщия 14}

\section{ЛАНДШАФТНЫЙ АНАЛИЗ И СИНТЕЗ КАК ОСНОВА КОМПЛЕКСНОЙ ОЦЕНКИ АНТРОПОГЕННЫХ ПРЕОБРАЗОВАНИЙ ПРИРОДЫ ПРИМОРЬЯ}

(на примере угольного и горнорудного производства)

Горнорудные и угольные минерально-сырьевые источники техногенеза (месторождения, проявления) в достаточной степени описаны в материалах территориальных геологических фондов, научноисследовательских институтов, экспедиций и в литературе по экологии (Геология.., [38]; В. П. Зверева, О.Н. Кравченко [60]; А. М. Ивлев и др. [69, 70] Крупская и др. [110, 111]; А. Ф. Махинова [129], В.Т. Старожилов [238, 245, 258, 262], А. И. Степанова и др. [272], Н. К. Христофорова [280], Р. J. Culhane [292] L.W. Canter [290, 291] и др.). Основным рассматриваемым в работе источником техногенеза является минерально-сырьевое производство (горная промышленность). Более 60 лет отрабатываются открытым и закрытым способами касситеритовые и касситеритсульфидные месторождения в Кавалеровском районе Приморья, значительное время (более 30 лет) разрабатываются Лучегорский и Павловский угольные разрезы и т.д. При разработке рудных тел открытым и закрытым способами на дневной поверхности остаются огромные горные выработки - расчистки, карьеры и штольни, а также отвалы вмещающих пород [256].

Характер и сила воздействия горнорудных и угольных предприятий на ландшафт определяется прежде всего способом добычи минерального сырья (открытым или закрытым). Воздействие происходит на всех этапах производственной деятельности: в процессе добычи полезного ископаемого и переработки минерального сырья, транспортировки и передачи конечного продукта потребителю. При освоении недр в Кавалеровском, Лучегорском и Павловском и др. районах Приморья образуется большое количество горнопромышленных отходов [256], складируемых в хво- 
стохранилища, происходит изъятие продуктивных земель (более 15000 га). Так, под Лучегорский буроугольный разрез была занята площадь пахотнопригодных земель 6122 га; Павловский - 5023; Липовецкий - 3077; Реттиховский - 487 га. К этой площади следует добавить более 1500 га, занятых под отвалы вскрышных горных пород. Угольные разрезы способствуют уничтожению почвенного покрова (изменение и уничтожение компонентов природного ландшафта показано на рис. 62), оны вызывают повсеместное нарушение естественного сложения горных пород (стратификации).

Созданные котлованы и отвалы на открытых разработках угля не только меняют морфологию поверхности, но и являются причиной изменения гидрологического режима территории. Рельеф в зоне действия каменноугольного разреза становится резко расчлененным. Амплитуда высот между самой низкой точкой в котловане и самой высокой на отвалах может достигать 500 м. Котлованы становятся водонакопителями, а поверхности отвалов подвергаются иссушению. Расчлененность рельефа способствует развитию эрозионных и денудационных процессов. Все это пре-

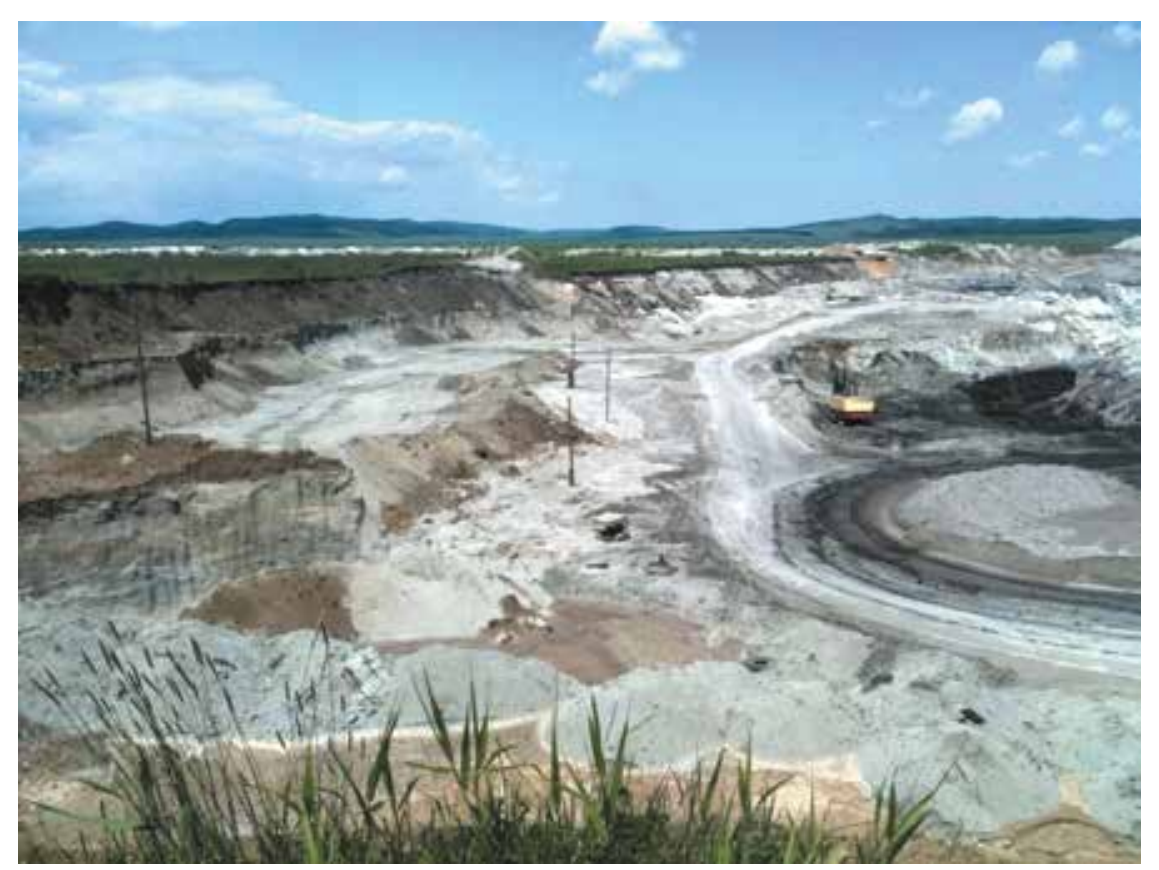

Puc. 62. Павловский техногенный ландшафт (западная часть) пятствует восстановлению растительного покрова. Одновременно с распространением эрозионных процессов вокруг отвалов, по линиям стока возникают вторичные геохимические потоки.

Добыча каменного угля подземным или шахтным способом также оказывает влияние на ландшафты. Она способствует образованию просадочных явлений, терриконов и уже упомянутых ранее вторичных геохимических потоков. Одновременно изменяется гидрологический режим территории и развиваются эрозионные процессы в виде промоин, неглубоких ложбин. Количество терриконов на поверхности зависит от размеров шахтного поля и глубины залегания каменного угля.

Таким образом, на всех этапах горного и угольного производства нарушаются компоненты природного ландшафта (фундамент, рельеф, воды, почвы, растительность). Особенности протекания процессов техногенеза рассмотрены в работах Л.Т. Крупской В.Т. [110, 111], Старожилова и др. [245-250, 252-258, 260 и др.], Goudie A. [300], Bisset R, [287] и др. В связи с этим возникает проблема оценки антропогенных трансформаций природной среды [298, 303].

Оценка ландшафтного подхода как основы комплексной оценки антропогенных преобразований природной среды.

Горнопромышленное производство (ГП), включающее взаимодействующие технические, транспортные и технологические подсистемы, и природные минерально-сырьевые комплексы в процессе добычи, переработки и транспортировки рассматриваются как геотехнические система (ГТС). Известно, что это - сложные объекты анализа проблемы взаимодействия общества и природы, включающего вопросы вхождения, взаимовлияния, сращивания технических устройств, природных комплексов и компонентов, возникновения отношений включения между ними. Характерная особенность ГТС - появление механизма регулирования и управления процессами функционирования этих сложных природнотехнических образований. Важнейшими свойствами ГП, как специфического объекта ГТС и географического исследования, являются:

1) Слияние или соединение разнокачественных структур (природных, технических, социальных);

2) Функциональная целостность, обусловленность вещественно-энергетическими и информационными связями;

3) Наличие подсистем контроля, регулирования, управления; 
4) Формирование сферы воздействия и зоны влияния ГП, трансформирующей сопряженные природные и хозяйственные структуры;

5) Вхождение в иерархию специализированных систем - горнотехнических и др. [17-19, 167].

Как показала практика, высокая сложность ГП требует междисциплинарных исследований. Особое значение придается реализации принципов рационального природопользования в процессе создания и становления ГП, ландшафтно-индикационному методу анализа природной среды и ее изменений.

Горное производство имеет определенный географический статус, определяющий антропогенно-техногенную ветвь ландшафтной географии территорий минерально-сырьевого освоения геосистем. ГП расположено в природном ландшафте, трансформирует его. Приведенный выше материал указывает на формирующуюся цепочку состояний территории ГП: природный ландшафт - изменяемый ландшафт - ландшафт преобразованный с ярко выраженными измененными компонентами и свойствами. Изучение цепочки состояний соответствующих территорий свидетельствует о том, что на территориях центров горной промышленности в связи с изменением свойств ландшафтов, происходят химические и механические загрязнения атмосферы, гидросферы, почвенно-растительного покрова: 1) атмосферные (загрязнение атмосферы: химическое, механическое); 2) водные (загрязнение поверхностных и подземных вод [293, 295, 296]); 3) геолого-геоморфологические (интенсификация неблагоприятных геолого-геоморфологических процессов, нарушение рельефа и геологического строения); 4) почвенные (загрязнение, эрозия дефляция); 5) биотические (сведение растительности, деградация лесов и др.); 6) комплексные (ландшафтные). В результате загрязнения, взаимодействия техногенеза и природных процессов в ландшафтах формируются локальные техногенно-нарушенные территории с фациями, урочищами и местностями модифицированными (измененными) и трансформированными, утратившими свою целостность, не способными к восстановлению. Под экологически значимыми свойствами ландшафтов понимаются те, которые могут способствовать или не способствовать проявлению экологических нарушений и проблем (например, слабый водообмен, неблагоприятный состав почв, мезо- и микроклиматические свойства, изменение рельефа, неблагоприятный геохимический состав воды и т.д.), или имеющие важное значение для жизнедеятельности человека (табл. 2). Выше отмечалось (глава 1, раздел 1.3), что отбор этих свойств (критериев, показателей, индикаторов) является одним из ключевых моментов в ходе исследования, поскольку необходимо определить точку отсчета при установлении уровня изменений этих свойств, свидетельствующих о возникновении экологической проблемы.

Изменение (модификация) свойств ландшафтов происходит в пределах определенных территориальных рубежей. Эти ареалы характеризуются качественным и количественным изменением не только компонентов (фундамента, рельефа, климата, вод, почв, растительности), но и изменением параметров свойств ландшафтов как систем. Степень их изменения может быть охарактеризована интенсивностью процессов, площадью распространения и спецификой последствий. Эти параметры изучает направление экология ландшафтов, представителями которого являются Б. В. Виноградов, С. Н. Кирпотин и др. ученые.

В Приморье до недавнего времени не было ландшафтной карты масштаба 1: 500000, но с её появлением, возможностями расчета площадей выделов стало возможным сравнение на количественном фоне изменений природных и исчисления техногенно-обусловленных свойств ландшафтов, важных для оценки степени их изменения, загрязнения компонентов и природных сред проходящих в границах распространения ландшафтов. Известно, что центр тяжести экологических исследований все больше переносится на изучение векторных (каскадных, коннекционных, парадинамических) экосистем с горизонтальными связями, которые осуществляются геопотоками воздушными, водными, литодинамическими, биогенными, связанными с антропогенными воздействиями (Э.Г. Коломыц, 2005 [95]). Необходимость изучения таких связей, особенно хорошо выраженных в ландшафтах горнопромышленных районов, превращает чисто экологические задачи в задачи ландшафтно-географические.

При анализе возможностей ландшафтного метода как основы комплексной оценки антропогенных преобразований ландшафтов горнопромышленных районов применен метод ландшафтной индикации. Он включает исследование индикаторов и индикационных связей, отражающих объекты индикации, обусловленных антропогенной трансформацией, разработкой мер по охране природной среды [17]. В процессе ландшафтных исследований территории наряду с локальными индикаторами - почвами, растительностью, рельефа, геологии, климата - важное значение 
имеет и интегральный - специфика морфологической структуры, которая показывает взаимосвязь элементов и компонентов ландшафтов, Морфологическая структура, сформировавшаяся при сложном взаимодействии эндогенных и экзогенных факторов, является объективным отражением сложных процессов вещественно-энергетического обмена между компонентами, поэтому анализ ее пространственной упорядоченности в системах любого ранга выступает как важный индицирующий природный процесс признак. Суть метода ландшафтной индикации в его приложении к познанию взаимосвязанных объектов природы, хозяйства заключается прежде всего в распространении знания о части объекта, или его структурного элемента на весь объект природопользования. [17]. Мы согласны с мнением В.И. Булатова о том, что метод ландшафтной индикации позволяет решать не только вопросы трансформации отдельных компонентов ландшафтов, но и расширить границы применимости метода и расширения его на такие научно-познавательные процессы:

1) Ландшафтно-индикационная интерпретация всей полученной информации по модификации ландшафтов и охране природы с учетом выявленного структурного и функционального сходства геосистем, их типологического подобия;

2) Создание на единой ландшафтной основе (для Приморья это ландшафтная карта масштаба 1: 500000) отраслевых тематических карт, оформление их взаимосвязанной и пространственно сопоставимой серии;

3) Разработка на основе ландшафтно-экологической концепции рациональной схемы горнодобывающей промышленности и охраны минерально-сырьевых ресурсов всей системы проектных документов;

4) Осуществление на основе ландшафтной индикации поиска причинных связей, в том числе прямых, опосредованных, косвенных (качество воды, геохимические особенности объекта и т.д.)

В условиях возрастания роли природоохранного фактора ландшафтная индикация выступает как основа выбора главного направления или даже стратегии хозяйствования. Особенно индикационная основа важна в условиях повышенного внимания к освоению Приморья и в целом территории Дальнего Востока.

Выполненные с учетом названных представлений практические проработки позволили сделать вывод о том, что существуют ландшафтные индикаторы антропогенной трансформации и модификации, устойчивости геосистем, воздействия на природную среду. Заслуживает внимание индикационный смысл пороговых значений нагрузок, территориально-дифференцированных нормативов предельно допустимой концентрации, коэффициентов изменений, воздействий, ресурсовоспроизводящих функций. Индикационная оценка подобных явлений, свойств и характеристик во многом облегчает поиск и определяет географическую дифференциацию мер по охране и воспроизводству природных ресурсов.

Каждая природная и модифицированная системы имеют пространственные ограничения. Определенную сложность представляет выявление границ сферы воздействия и взаимодействия ландшафтных компонентов горнопромышленного объекта и зоны влияния всей горнопромышленной геосистемы, как качественно нового формирования, на прилегающие ландшафты. Параметры сферы воздействия и взаимодействия зависят прежде всего от горнопромышленной подсистемы, зоны влияния всей горнопромышленной системы - от природной. Например, зоны влияния Дальнегорской горнодобывающей системы по рекам распространяется на сотни км [294]. Для получения данных по площадям природных ландшафтов необходимо иметь оцифрованную региональную ландшафтную карту. Нами, как отмечалось выше, такая карта составлена, подсчитаны площади выделенных на ней выделов ландшафтов. Имея данные по площадям природных ландшафтов, мы использовали эти материалы для подсчета соотношения площадей модифицированных и природных ландшафтов. В практике настоящих исследований, учитывая высокий уровень изученности территорий промышленных производств, наличие материалов по площадному изменению рельефа, трансформации растительности и других компонентов, выявилась определенная достаточность материалов, переданных в фонды Комитета по природопользованию.

Выявлено, что для оценки антропогенных воздействий на природные системы при формировании горнопромышленного производства, и связанных с ними неблагоприятных процессов и явлений целесообразно использование двух подходов: геосистемного и покомпонентного. Проанализированы, в частности, изменения в литологии и рельефе, грунтовых и поверхностных водах, атмосфере и микроклимате, почвенном покрове и растительности. Накопленная информация при ландшафтном анализе как научной основе антропогенных изменений при геосистемном подходе позволяет в пределах ареалов (площади) ландшафтов: 
1) Выявить основные виды, масштаб и характер, тенденции изменения природных комплексов и отдельных компонентов;

2) Установить связи между изменениями в природе и вызывающими их воздействия с учетом цепных реакций в природных системах;

3) Провести районирование по характеру и масштабам изменений в природе, выявить ареалы с критическим ее состоянием;

4) Определить степень трансформации природы по природоохранно-экологическим критериям.

Различия в характере, деятельности и интенсивности воздействия на природные ландшафты в сочетании с природоохранными естественно-научными подходами дают основу для формирования региональной, т.е. учитывающей местную специфику, природоохранно-экологической концепции горнопромышленного производства, разработки нормативов, градаций качества среды после включения в оценку многочисленных систематизированных данных по отмеченным выше видам загрязнения компонентов Bce, что мы отметили выше как направленный, постоянно усиливающийся процесс модификации и трансформации, происходит в ландшафтах с определенной площадью. При наличии такой пространственной компоненты важным этапом работы явился анализ сложившийся системы использования территории, показ пространственной организации ландшафтов и применение сравнительных площадных характеристик природных и модифицированных ландшафтов.

Обозначим площадь природного (эталонного) ландшафта ЛП, а площадь модифицированного ЛТ, затем разделим площади друг на друга и получим отношение, характеризующее площадное изменение ландшафтных свойств (ЛС). То есть, получена формула

$$
\text { ЛС }=\text { ЛП / ЛТ }
$$

где: ЛП - площадь природного (эталонного) ландшафта;

ЛТ - площадь модифицированного ландшафта;

ЛС - коэффициент площадного изменения соответствующей

таксономической единицы ландшафта;

Расчет площадного изменения ландшафта производился на примере Павловского угольного разреза. Он расположен в горно-долинной местности с площадью 561, 4 кв. км. (табл. 20). Техногенный ландшафт Павловского разреза занимает 50,2 кв. км (соответствует отводу земель). Применив отмеченную выше формулу, получаем величину коэффициента площадного изменения горно-долинно-речной местности. Он равен 11,2. Эти несложные арифметические действия дают возможность по коэффициенту рассчитывать изменения выделов ландшафтов, сравнивать их между собой, исследовать вопросы связанные с модификацией структуры и организации ландшафтов.

Получены данные площадного изменения свойств ландшафтов угольного производства в процентах от площади выделов природных ландшафтов Приморья. В частности, на Павловском угольном промышленном центре площадь изменения ландшафта в пределах местности составляет $8,8 \%$. Подсчеты производились по формуле

$$
\mathrm{x}=\text { ЛТ } 100 \% / \text { ЛП, }
$$

где: $\mathrm{x}$ - процент площадного изменения модифицированного ландшафтов в пределах соответствующей иерархической единицы ландшафта;

ЛТ - площадь измененного ландшафта;

ЛП - площадь природного (эталонного) ландшафта.

Получение данных в процентах или коэффициентах определяется задачами исследований.

На основе составленной ландшафтной карты Приморья масштаба 1: 500000 и данных по пространственно-площадной дифференциации ландшафтов, получены данные не только по общему изменению ландшафтных геосистем, но и по компонентным индикаторам трансформации ландшафтов. Под компонентными индикатором (свойством) ландшафта понимаются те его параметры, механизмы функционирования, которые могут способствовать или не способствовать проявлению экологических проблем, или которые имеют важное значение для жизнедеятельности человека. Они проявляются при сведении растительности, уничтожении природных почв, изменениях рельефа, загрязнении компонентов и т.д.). Теоретические основы оценки подобных изменений по результатам анализа площадей природных и модифицированных ландшафтов рассматриваются многими учеными. Так, Б. И. Кочуров [107] антропогенную нагрузку на ландшафт оценивает по видам использования земель и характеру заселения территории По его же мнению, «поскольку экологическая проблема определяется нами по изменению свойств ландшафтов, то степень ее проявления может быть охарактеризована через интенсивность и площадь распространения этих изменений и характер последствий» [стр. 17, 107]. 
Для получения данных по площадям и свойствам природных ландшафтов региона необходимо иметь оцифрованную ландшафтную карту. Нами, как отмечалось выше, такая карта составлена, подсчитаны площади выделенных на ней выделов ландшафтов и имея данные по площадям природных ландшафтов мы использовали эти материалы для подсчета соотношения площадей индикаторов модифицированных и природных ландшафтов. Как в целом природный, так и модифицированный ландшафты характеризуются, как отмечалось выше, индикационными параметрами. Их выявление и анализ - основное при определении степени трансформации ландшафтов и при определении ландшафтноэкологических последствий и природоохранных мероприятий. Но далеко не все индикационные составляющие удается представить в количественной, исчисляемой форме. Сравнительно легко определяются такие элементы, как изменения химического состава вод, почв, объемы извлекаемого сырья, породы, уменьшение объемов биомассы, сокращение площадей угодий, земельных ресурсов, уничтожение уникальных природных урочищ, охраняемых видов фауны и флоры. Гораздо труднее определить явления и процессы, возникающие как вторичное следствие техногенных факторов, цепи трансформации.

Индикационные составляющие любых анализируемых систем распространены на определенной площади и учет соотношения площадей природных и модифицированных ландшафтов при анализе трансформации горнопромышленных территорий показателен в отношении определения степени их модификации. При анализе ландшафтного подхода для целей изучения степени трансформации ландшафтов по индикаторным компонентам степень индикации нами изучена также по соотношению площадей индикаторов природных и модифицированных систем. Определялись соотношения площадей почвенных, рельефных, геохимических и др. индикаторных компонентов, они обозначены коэффициентами.

Выделяется ряд коэффициентов: К1, К2, К3 и т.д.

$\mathrm{K} 1, \mathrm{~K} 2, \mathrm{~K} 3, \mathrm{Kn}$ - коэффициенты соотношений площадей ландшафтных природных (эталонных) и техногенных индикаторных компонентов ландшафтов (почвенных, растительных, геохимических и т.д.). Подсчет коэффициентов производился по формуле:

$$
\mathrm{K}=\text { ПЛ / КЛ, }
$$

где: К - коэффициент соотношения площадей соответствующего компонентного индикатора ландшафта;
ПЛ - плошадь природного (эталонного) ландшафта;

КЛ - площадь модифицированного соответствующего компонентного индикатора ландшафта;

Расчет компонентного (на примере уничтоженной почвы, природного индикатора ландшафта) изменения ландшафта производился на примере Реттиховского угольного разреза, занимающего 4,9 кв.км. Он расположен в низкогорной лесной широколиственной с порослевыми зарослями на алевролит-песчаниковом комплексе местности с площадью 34,1 кв. км. (табл. 20). Применив данную выше формулу, получаем величину коэффициента изменения компонентного почвенного индикатора местности. Он равен 6,8.

Такие данные получены не только по Павловскому и Реттиховскому угольным разрезам, но и по Лучегорскому и Липовецкому (табл. 20) и др.

Анализируя данные коэффициентов соотношения индикаторов ландшафтов и площадной нарушенности природных местностей на Лучегорском, Павловском, Липовецком, Реттиховском (табл. 20) можем констатировать, что в общем эксплуатация отмеченных угольных разрезов происходит в условиях сильных $(\kappa-3,2 ; 6,8)$ и средних $(к-11,2 ; 11,4)$ экологических изменений местностей.

По полученным данным выделены три степени изменения природных свойств: сильное (например, изменение природных свойств ландшафта с коэффициентами менее 10), среднее (коэффициенты находятся в пределах от 10 до 50), и слабое (превышение коэффициентов составляет более 50). В реальных условиях это выражается в уничтожении многих фаций и урочищ (волни-

таблица 20

Коэффициенты соотношения площадей природных и модифицированных ландшафтов (фрагмент)

\begin{tabular}{|l|c|c|c|}
\hline $\begin{array}{c}\text { Промышлен- } \\
\text { ный центр }\end{array}$ & $\begin{array}{c}\text { Плдешадь } \\
\text { ландшафта } \\
\text { кв. км }\end{array}$ & $\begin{array}{c}\text { Площадь, } \\
\text { кв. км при- } \\
\text { родноголан- } \\
\text { дшафта }\end{array}$ & $\begin{array}{c}\text { Коэффи- } \\
\text { циент со- } \\
\text { отношения } \\
\text { площадей }\end{array}$ \\
\hline Лучегорский & 61,2 & 193,6 & 3,2 \\
Павловский & 50,2 & 561,4 & 11,2 \\
Липовецкий & 30,8 & 343,3 & 11,4 \\
Реттиховский & 4,9 & 34,1 & 6,8 \\
\hline
\end{tabular}


стых равнинных, пологосклонных полисубстратных, аккумулятивных долинно-речных и др.) замене их на техногенные (отвальные, котлованные и др.).

Анализ ландшафтных материалов по Приморскому краю и полученные данные по коэффициентам и площадному изменению свойств ПТК дает возможность выделить основные виды изменения ландшафтов: природно-ресурсные, динамические, ландшафтно-генетические. Природно-ресурсные связаны с истощением и утратой природных ресурсов и ухудшением хозяйственной деятельности на территории. Ландшафтно-генетические обусловлены нарушением целостности ландшафтов. Динамические показывают направленность техногенной трансформации и изменении я в эволюционном развитии.

Изучение свойств ландшафтов территорий угольного и горнорудного производств позволило выявить антропогенные изменения по основным видам техногенного воздействия: нарушению целостности ландшафтов, связанные с истощением и утратой природных ресурсов, причине возникновения, пространственному охвату территории, остроте проявления негативной ситуации. Изменение свойств ландшафтов приводит к изменению природной среды. В свою очередь, изменение природной среды в результате антропогенных воздействий, ведущее к нарушению структуры и функционирования природных систем (ландшафтов) и приводящее к негативным социальным, экономическим и иным последствиям рассматривается как экологическая проблема [107]. Пространственно-временное сочетание экологических проблем, определяющее состояние систем жизнеобеспечения человека и создающее определенную экологическую обстановку на территории разной степени неблагополучия. (остроты) представляет собой экологическую ситуацию [107]. Анализ изменения ландшафтных систем показывает, что в результате антропогенного воздействия формируются территории с экологическими проблемами и ситуациями. При анализе возможных экологических ситуаций применены признаки их выделения (табл. 21).

Учитывая изложенное выше об основных минерально-сырьевых источниках, модификации компонентов ландшафтов и антропогенному изменению индикаторов ландшафтов можно констатировать, что в районах центров угольного и горнорудного производства происходят ландшафтные изменения, с которыми связано формирование геолого-геоморфологических, атмосферных, почвенных, биотических, комплексных ландшафтных эко-
Характеристика экологических проблем угольных и горнорудных территорий промышленных центров Приморского края

\begin{tabular}{|c|c|}
\hline $\begin{array}{c}\text { Признак (критерий) } \\
\text { проблемы }\end{array}$ & Проблемы и ситуации \\
\hline Причина возникновения & Антропогенные (техногенные) \\
\hline $\begin{array}{l}\text { Структура (сложность) ситуа- } \\
\text { ции }\end{array}$ & Сложные \\
\hline $\begin{array}{l}\text { Основной изменяющийся ком- } \\
\text { понент природы }\end{array}$ & $\begin{array}{l}\text { Атмосферные, водные, почвен- } \\
\text { ные, геолого-геоморфологиче- } \\
\text { ские, биотические, комплексные }\end{array}$ \\
\hline Время проявления & Длительные \\
\hline Скорость развития & $\begin{array}{l}\text { Быстроразвивающиеся, скачкоо- } \\
\text { бразные медленно развивающиеся }\end{array}$ \\
\hline Принадлежность к территории & Местные \\
\hline $\begin{array}{l}\text { Пространственный охват (мас- } \\
\text { штабность) }\end{array}$ & Локальные \\
\hline Зональность & Незональные \\
\hline Форма проявления & Площадные \\
\hline Последствие & $\begin{array}{l}\text { Антропоэкологические, природ- } \\
\text { но-ресурсные }\end{array}$ \\
\hline Острота & $\begin{array}{l}\text { Умеренно острые (напряженные, } \\
\text { конфликтные) }\end{array}$ \\
\hline Возможность решения & Трудно решаемые \\
\hline Приоритетность решения & Приоритетные \\
\hline Способ решения & $\begin{array}{l}\text { Методы: организационные, эко- } \\
\text { номические, технические и т.д. }\end{array}$ \\
\hline
\end{tabular}

логических проблемных ситуаций. По степени изменения свойств (индикаторов) ландшафтов большинство экологических ситуаций территорий угольных и горно-рудных центров Приморского края относится к напряженным.

Важную функцию ландшафтные материалы выполняют в оценке антропогенных изменений природной среды территорий как регионального, так и локального уровней. Они имеют значение для выявления и изучения стадий деградации природной среды и определения направлений нормализации ситуации. При любой оценке состояния территорий она в целом проводится на основании учета характера изменений свойств ландшафтов и выявления их последствий. В результате изучения модификации локальных и региональных ландшафтов, связанных с функционированием угольных и горнорудных центров на основании соотношения 
свойств ландшафтов произведена оценка экологического состояния ландшафтов и связанных с этим современных экологических ситуаций: удовлетворительная (неизмененный ландшафт), конфликтная (наблюдаются незначительные изменения в ландшафте), напряженная (признаки деградации отдельных компонентов ландшафтов), критическая (деградация отдельных компонентов ландшафтов), кризисная (деградация ландшафтов), катастрофическая (глубокие и необратимые изменения, деградация ландшафтов) (табл. 22)

Таблица 22

\section{Категории экологических ситуаций по степени остроты} (по Б.И. Кочурову, [107] с изменениями автора)

\begin{tabular}{|c|c|}
\hline $\begin{array}{l}\text { Экологическая } \\
\text { ситуация }\end{array}$ & Характеристика ситуации \\
\hline Удовлетворительная & $\begin{array}{l}\text { Из-за отсутствия прямого или косвенного } \\
\text { антропогенного воздействия все показатели } \\
\text { свойств ландшафтов не изменяются. }\end{array}$ \\
\hline Конфликтная & $\begin{array}{l}\text { Наблюдаются незначительные в пространстве } \\
\text { и во времени изменения в ландшафтах, что } \\
\text { ведет к сравнительно небольшой перестрой- } \\
\text { ке структуры ландшафтов и восстановлению } \\
\text { в результате процессов саморегуляции природ- } \\
\text { ного комплекса или проведения несложных } \\
\text { природоохранных мер. }\end{array}$ \\
\hline Напряженная & $\begin{array}{l}\text { Негативные изменения в отдельных компо- } \\
\text { нентах ландшафтов, что ведет к нарушению } \\
\text { или деградации отдельных природных ресур- } \\
\text { сов. При соблюдении природоохранных мер } \\
\text { напряженность экологической ситуации спа- } \\
\text { дает. }\end{array}$ \\
\hline Критическая & $\begin{array}{l}\text { Возникают значительные и слабо компенси- } \\
\text { руемые изменения ландшафтов, происходит } \\
\text { быстрое нарастание угрозы истощения или } \\
\text { утраты природных ресурсов.. }\end{array}$ \\
\hline Кризисная & $\begin{array}{l}\text { Приближается к катастрофической, в лан- } \\
\text { дшафтах возникают очень значительные } \\
\text { и практически слабо компенсируемые изме- } \\
\text { нения, происходит полное истощение при- } \\
\text { родных ресурсов. }\end{array}$ \\
\hline Катастрофическая & $\begin{array}{l}\text { Глубокие и часто необратимые изменения } \\
\text { природы, утрата природных ресурсов. }\end{array}$ \\
\hline
\end{tabular}

Использование картографических ландшафтных материалов помогает эффективнее и объективнее оценивать степень остроты экологических проблем и масштаб изменений ландшафтов путем более обоснованного и четкого определения границ ландшафтноэкологических преобразований. Каждая единица ландшафта на масштабной ландшафтной карте имеет достаточно обоснованную границу. Границы ландшафтов будут ограничивать (резко, не резко, коннекционно, подчиняются геопотокам или нет и т.д.) изменения ландшафтных свойств.

Специфика ландшафтного видения антропогенной модификации ландшафтов и усиливающее внимание государства к освоению Дальнего Востока становится существенным элементом при разработке путей дальнейшего развития минерально-сырьевого природопользования и природно-экологических охранных действий. На существующих угольных и горнодобавающих предприятиях Приморья все еще остаются не решенными многие связанные с продолжающейся разработкой недр вопросы, требующие своих решений. В том числе по направленному процессу продолжающейся модификации ландшафтов:

1) В связи с продолжающимися сведением растительности, уничтожением почв, разрушением рельефа, стратификации пород нарушается динамика геосистем, приводящей к нарушению норм реакции функциональных блоков, дисбалансу ведущих функциональных связей. Это приводит к нарушению ритмики и распаду устойчивой структуры;

2) Противоположно направленные природно-ландшафтный и антропогенный пути развития вызывают быструю перестройку структуры функциональной организации;

3) При достаточно полном проведении рекультивации, посадки леса и т.д. происходит частичное восстановление ландшафтного разнообразия с последующей оптимизацией обстановки на новом уровне, но при сохранении тенденции разрушения природных ландшафтных связей;

4) При существуюшем отсутствии ландшафтных материалов, в том числе картографических, не учитываются ландшафтная природная и хозяйственная дифференциация, территориальные природно-хозяйственные связи, что приводит к нарушению качества в выборе оптимальных путей развития ГП и проведения природноохранно-экологических мероприятий;

5) Отсутствие региональных ландшафтно-промышленных картографических материалов в оценке антропогенных преобра- 
зований ландшафтной среды негативно влияет на стратегические решения по планированию и развитию освоения Приморья и проведение природноохранно-экологических мероприятий.

Присутствие негативных вопросов по природноохранно-экологическим проблемам и все еще продолжающаяся модификация ландшафтов выдвигает идею о направленном процессе техногенной трансформации ландшафтов в Приморье в связи с использованием минеральных ресурсов. Имея цель решения задач минимизации воздействия горнодобывающего производства, природноохранно-экологическая деятельность обретает четкие ландшафтные географические аспекты и должна развивать регионально-геосистемные подходы. В этом направлении, прежде всего, необходимо:

1) Провести на всех предприятиях угольной и горнодобывающей промышленности переоценку и осмысливание ландшафтной модификации и обстановки природноохранно-экологической системы;

2) Оценить степень насыщенности ландшафтной территории объектами ГП. При этом:

- должны быть использованы ландшафтные модели их размещения;

- даваться оценка плотности размещения объектов;

- должны быть установлены природно-хозяйственные связи;

- определены источники воздействия на ландшафты, их типь и размещение;

3) Разработать с использованием картографических ландшафтных материалов программу ландшафтно-экологических исследований, являющейся важнейшей задачей ландшафтной географии, что облегчается ее системным видением природы. История становления современной ландшафтной структуры может рассматриваться как процесс направленной трансформации природных систем, позитивные и негативные стороны которого определяют общую природноохранно-экологическую ситуацию.

Применение ландшафтного метода (на примере ГП) при оценке антропогенных преобразований и направленного процесса трансформации ландшафтных систем показывает, что они существуют во множестве типов, дифференцируются как специфические локальные территориальные образования, стабильное функционирование которых зависит от устойчивого равновесия всей системы «человек-общество-природа» и оптимизации природопользования.
Наработанные данные (на примере ГП) с применением ландшафтного подхода при исследовании антропогенных преобразований ландшафтов Приморья и поиске процедур, предшествующих реализации решений по развитию хозяйственной и природоохранно-экологической деятельности, показывают на целесообразность разделения ландшафтно-региональных исследований в природопользовании на несколько этапов. Разделение на этапы проводится с учетом опыта природопользования на юге Западной Сибири [18, 19].

1. Информационный - сбор информации для общего представления о региональной системе «природа - население - хозяйство» по направлениям:

- установить ландшафтную картографическую обеспеченность исследований, если она отсутствует, то ее надо восполнить;

- учет природной и хозяйственной дифференциации, территориальных природно-хозяйственных связей, системы расселения;

- типы природно-хозяйственных систем, природопользование;

- источники воздействия на ландшафты, их типы и картографический ландшафтно-географический их статус в географическом пространстве геосистем;

- установить картографическую обеспеченность по видам природопользования;

2. Аналитический - анализ актуальных природоохранно-экологических параметров. «Субъективные» параметры - показатели производственных и природопользовательских воздействий (выбросы, мощность очистных сооружений, площади вырубок и лесопосадок, распашка, эрозия и противоэрозионные мероприятия и т.д.), интенсивность и качественный состав воздействующих элементов. «Объективные» параметры - оценка состояния природных систем и сред, граничные значения (нормативы, ГОСТы, показатели емкости среды и ее устойчивости) к региону и его ландшафтной структуре.

3. Прогнозный этап - описание природоохранных проблем и их следствий, реакций среды по типу «воздействие - изменение» с параметрами: масштаб явлений, интенсивность, качественная характеристика. Обобщение информации, прогнозные модели и карты.

4. Разработка стратегии. Определение территориально дифференцированной стратегии охраны природы и рационального природопользования, регулирование геотехнических систем, взаимоувязка предлагаемых ведомственно-отраслевых решений, выбор 
направлений деятельности с учетом региональных и ландшафтноэкологических условий. Экспертиза проектов.

Возможные варианты стратегии природопользования при условии совершенствования и необходимой адаптации экологической и природоохранной законодательной и нормативно-правовой базы, механизмов их реализации в конкретных условиях, параллельно с ростом ответственности за их исполнение:

- стабилизация существующего состояния природных систем, предотвращение ухудшение. С инвентаризацией состояния природных систем, оценкой их количества и качества, мониторинг с применением ландшафтных картографических материалов;

- поддержание существующих процессов естественного восстановления при сохранении механизма устойчивости. С определением и выделением наиболее функционально значимых ландшафтных выделов, уникальных природных объектов

- переориентация тенденций ухудшения на стабилизацию и улучшение ситуации путем активной природоохранной деятельности. С ландшафтно-природоохранно-экологическим планированием, поисками и применением адаптированных к ре гиональным условиям экологическим технологий в пределах эксплуатации и переработке природных ресурсов, предусматривающих максимально возможное снижение антропогенных воздействий как на эксплуатируемые природные ресурсы, так и окружающую среду;

- невмешательство в процессы изменения природы в допустимых пределах (при отсутствии, например, средств), но с проведением ландшафтного мониторинга, ландшафтно-экологического планирования, упреждающей подготовкой условий привлечения модифицирующих мероприятий, развитием системы контроля процессов природопользования.

В заключение можно сделать следующие выводы:

1. Учитывая усиливающееся внимание государства к освоению Дальнего Востока можно утверждать, что разрабатываемые основные направления ландшафтной географии в условиях углубления процесса направленной антропогенной трансформации являются значимыми при разработке путей дальнейшего развития минерально-сырьевого природопользования и оптимизации природоохранной деятельности.

2. Отсутствие региональных ландшафтно-картографических материалов при оценке антропогенных преобразований геосистем при возрастающей потребности учета ландшафтной и хозяйствен- ной дифференциации, новых территориальных связей, негативно влияет на стратегические решения по планированию и развитию осваиваемых регионов.

3. Развитие современных геосистемных исследований на основе среднемасштабного картографирования - это необходимый путь развития ландшафтной географии слабо изученных в этом плане регионов, представляющий данные для многоступенчатого, с учетом масштабов и уровней, содержательного анализа современного природопользования.

4. Применение ландшафтного метода (на примере горного природопользования) при оценке антропогенных преобразований и направленности процесса трансформации ландшафтных систем показывает, что они реализуются во множестве типов, дифференцируются как специфические локальные территориальные образования, стабильное функционирование которых необходимо для устойчивого равновесия всей системы «человек - общество - природа» и оптимизации природопользования в изученном региональном звене.

5. Проведенные исследования, базирующиеся на картографировании ландшафтов и их структур, оценке данных по изменению свойств ландшафтов и их пространственно-площадному распространению с учетом компонентно-средовой дифференциации, рассматриваются автором как базовые для комплексной оценки антропогенных преобразований природной среды, оптимизации природопользования, конструктивного начала в обеспечении экологической безопасности минерально-сырьевого природопользования Приморского края. Они могут служить основой многоцелевых естественно-научных и прогнозно-экономических исследований, в т.ч. при разработке концепций устойчивого развития регионов.

6. Проведенные многолетние исследования - региональное звено продолжающихся многоплановых ландшафтно-экологических исследований Азиатской России: В.И. Булатова [17-19], 3. Г. Мирзехановой [138-140], А.Ф. Махиновой [129], Т. И. Коноваловой [], В. М. Плюснина [157, 158], Д. В. Черных [282, 283], Ю. М. Семенова $[170,171]$ и др. В Забайкалье, Хабаровском крае, на всём юге Сибири подобные исследования составляют ландшафтно-географическую основу комплексной оценки антропогенных преобразований природной среды, типизации и классификации природных и антропогенных ландшафтов, проведения прогнозно-экономических исследований и решения 
задач, поставленных правительством России по освоению Сибири и Дальнего Востока.

7. Полученные данные необходимо рассматривать как региональное звено в изучении модификации ландшафтов и в формировании политики природопользования стран АТЭС (Старожилов, 2009 [253, 2543]). Только совместными, межгосударственными, усилиями можно определить рациональную политику сохранения экологического баланса на территориях Приморья, Китая, Кореи, Японии и других стран АТЭС. Формированию природоохранно-экологической политики помогают ландшафтные карты, а применение ландшафтного подхода обеспечивает необходимую комплексность, пространственную сопряженность и научную достоверность. Предлагается рассмотреть возможности межгосударственного распространения единого ландшафтного подхода и использования ландшафтных карт для изучения экологического равновесия и формирования экологической политики стран АТЭС.

\section{Контрольные вопросы}

1. Раскройте горнорудные и угольные источники техногенеза.

2. Охарактеризуйте влияние способа добычи минерального сырья на ландшафт.

3. Раскройте компоненты нарушения ландшафта при воздействии на него добычи минерального сырья.

4. Раскройте понятие геотехническая система (ГТС).

5. Раскройте понятие горнопромышленное производство (ГП).

6. Охарактеризуйте цепочку состояния ГП формирующкюся при различной степени трансформации ландшафта.

7. Раскройте понятие экологическое свойство ландшафта.

8. Раскройте понятие экологическая ситуация.

9. Раскройте понятие экологическая проблема.

10. Охарактеризуйте метод ландшафтной индикации.

11. Охарактеризуйте возиожности применения метода индикации при изучении модификации ландшафта.

12. Раскройте понятие геосистемного подхода при ландшафтной индикации ГП.

13. Раскройте понятие покомпанентного подхода при ландшафтной индикации ГП.

14. Охарактеризуйте роль оцифрованных ландшафтных карт при изучении модифицированных площадей ландшафтов.
15. Раскройте понятие общих и компонентных коэффициентов модификации ландшафтов.

16. Охарактеризуйте возможности изучать изменения свойств ландшафтов по коэффициентам модификации и какие основные виды свойств можно изучать.

17. Охарактеризовать значение применения ландшафтного метода при изучении степени истощения и утраты природных ресурсов, остроты проявления негативных ситуаций.

18. Раскройте возможные последовательные этапы изучения модифицированных территорий ГП при применении ландшафтного подхода.

19. Охарактеризуйте информационный этап изучения модификации ГП.

20. Охарактеризуйте аналитический этап изучения модификации ГП.

21. Охарактеризуйте прогнозный этап изучения модификации ГП.

23. Охарактеризуйте стратегический этап изучения модификации ГП. 


\section{Лекция 15}

\section{ЗАКЛЮЧЕНИЕ}

1. Представляемая работа лежит в сфере научных интересов ландшафтной географии, включающей природное районирование территории, её регионального звена, своеобразие которого не только в палеогеографии, но и в континентально-океанической дихотомии, законе фундаментального дуализма суши и моря парности в организации и функционировании, единстве и противоположности приморских и континентальных ландшафтов и геосистем. Исследования в этой области физико-географической науки, нацеленные на разработку ландшафтно-природноохранноэкологических основ природопользования, проводятся в связи с проблемой необходимости обоснования оптимизации геосистем в условиях хозяйственной деятельности и повышенного внимания государства к освоению Приморья и Дальнего Востока.

2. Применяемая в ландшафтно-географических исследованиях система методов и подходов должна быть адекватна сложности проблемы взаимодействия общества и природы, трансформации ландшафтных систем в процессе природопользования. Усложнение территориальной структуры геосистем, изменение природно-обусловленных условий жизнедеятельности и хозяйствования в современных условиях техногенного пресса требует современного понятийного аппарата, картографических ландшафтных документов.

3. Горные и равнинные территории Приморья по материалам, наработанным ландшафтной географией, включающей многие параметры (удаленность от моря, вытянутость вдоль прибрежной зоны Тихого океана, климатические параметры, компонентную палеогеографию в широком смысле и др.) относятся к особым окраинно-континентальным, горным геосистемам и поясам. По ландшафтной таксономии в Приморье классических платформенных равнин нет, а имеющиеся равнинные участки это части горных подвижных поясов, рифтогенных структур.
4. Главный вклад ландшафтной географии Приморья в естественно-научное познание региона - заполнение информационной ландшафтной ниши картографическими материалами масштабов 1: 1000000 и 1: 500000 , тематически продолжающими ландшафтное картографирование и описание России. При среднемасштабном картографировании территория Приморья, использование регионально-типологической классификации позволило отразить особенности геосистем, проявляющие в различных частях их ареалов, а описание выявило свойства и степень различия между ландшафтами. В ландшафтной структуре ландшафтов Приморья, путем анализа сопряженности, взаимосвязей компонентов выявлено 2 класса, 4 подкласса, 12 родов, 94 вида ландшафтов и 3043 местности.

5. Развитие современных геосистемных исследований с применение их среднемасштабного картографирования - это необходимый путь развития ландшафтной географии слабо изученных в этом плане регионов, дающий данные для многоступенчатого анализа соотношений между разноуровневыми по масштабу (планетарный, региональный, локальный) и отличающимися по содержанию ландшафтными геосистемами.

6. На основе обзора положения Приморья в системе ландшафтов России, можно сделать несколько выводов:

- предлагаемые классификации и подготовленные (опубликованные) ландшафтные карты заложили основы мелкомасштабного ландшафтного картографирования региона;

- имеющийся опыт может и частично использован при создании ландшафтных карт другого масштабного ряда - среднемасштабных (миллионных и полумиллионных);

- новые картографические произведения должны опираться на значительно возросшую естественно-научную базу ландшафтной географии, созданные в последние годы геологические, почвенные, геоморфологические, геоботанические карты;

- современные ландшафтные карты должны отражать новые представления, новые подходы к ландшафтам как образованиям намного более сложным, чем это виделось 25-30 лет назад. Для того, чтобы оставаться в фарватере общего природоведения, ландшафтной географии необходимо сочетать ландшафтно-картографический подход с модернизацией ландшафтной теории, переходить к синергической парадигме, расширению региональных исследований пространственно-временной организации геосистем и их биосферных функций. 
7. Новые задачи повышают требования к информации и вызывают необходимость создания таких карт геосистем регионов, которые являются итогом многогранного научного процесса и отражают особенности самоорганизации геосистем. Анализ картографических данных, воспроизводящих различные аспекты геосистем и характер антропогенного воздействия на них, дает возможность прогнозирования направления их трансформации в естественных и антропогенных условиях.

8. При исследованиях важно учитывать все компоненты и факторы ландшафта. Однако в условиях континетально-океанической дихотомии возрастает роль анализа тектоники и вещественного состава. Тектонический режим определяет потенциал динамики и стабильности, а вещественные комплексы, являясь поставщиками материала (геохимического, минерального и т.д.), характеризуют вещественно-материальный потенциал геосистем. Речь идет о направляющем геологическом потенциале развития ландшафтов (это в свое время особо подчеркивал классик ландшафтоведения В.А. Солнцев), о геологическом качестве, которое понимается как способность фундамента ландшафтов за счет собственного геологического природного потенциала в течение длительного времени сохранять и поддерживать динамику развития и вещественно-геохимический потенциал территории.

9. Статистические исследования геосистем являются современным средством познания, соответствующим усложнившимся научным задачам ландшафтной географии в связи с новыми представлениями, развивающимися в естествознании. Количественные характеристики в свете познания географического пространства дают возможность на системном уровне изучать дифференциацию ландшафтных геосистем, пороговые значения начала отсчета возникновения (с учетом реально исчисляемых предельно допустимых норм техногенных нагрузок) природоохранно-экологических проблем. Эти базовые характеристики ландшафтной географии делают возможным изучение географических ситуаций в цифровом поле с перспективой создания математико-картографических моделей.

10. Применение ландшафтного метода (на примере горно-промышленного производства) при оценке антропогенных преобразований и направленного процесса трансформации ландшафтных геосистем показывает, что они реализуются во множестве типов, дифференцируются как специфические локальные территориальные образования, стабильное функционирование которых зависит от устойчивого равновесия всей системы «человек-обществоприрода» и оптимизации природопользования.

11. Сложившиеся тенденции преобразования региональной структуры геосистем свидетельствует о дальнейшем развитии процессов модификации и ее направленности. Антропогенная деятельность существенно усиливает сложившиеся тенденции, резко обостряя неблагоприятные явления. В настоящее время значительная часть геосистем региона нарушена антропогенным воздействием, которое затрагивает также значительную часть их слабоустойчивых категорий. Это определяет условия их функционирования на грани критических.

12. Полученные на примере горно-промышленного производства с применением ландшафтного подхода данные при исследовании антропогенных преобразований ландшафтов Приморья и поиске процедур, предшествующих реализации решений по развитию хозяйственной и природноохранно-экологической деятельности, показывают на целесообразность разделения региональных исследований с применением ландшафтного метода в природопользовании на несколько этапов: информационный, аналитический, прогнозный, разработка стратегии природопользования. Для Приморья актуально внедрение имеющихся ландшафтных данных во все эти сферы.

13. Проведенные исследования, базирующиеся на картографировании ландшафтов и их структур, оценке данных по изменению свойств ландшафтов и их пространственно-площадному распространению с учетом компонентно-средовой дифференциации, рассматриваются автором как базовые для комплексной оценки антропогенных преобразований природной среды, оптимизации природопользования, конструктивного начала в обеспечении экологической безопасности минерально-сырьевого природопользования Приморского края. Они могут служить основой многоцелевых естественно-научных и прогнозно-экономических исследований, в т.ч. при разработке концепций устойчивого развития регионов.

14. Объективная оценка роли географической среды в жизни и развитии общества в сочетании с ландшафтным подходом открывает новые возможности для объяснения закономерностей в хозяйственном освоении территории, использовании комплекса ресурсов, создании экологически безопасных условий освоения и т.д. Теоретический потенциал ландшафтоведения, как ядра физической географии и ландшафтной географии, несмотря на на- 
личие нерешенных или спорных вопросов, имеет фундаментальное значение для разработки генеральной стратегии поведения человека в его природном окружении. Потенциал географической науки, в т.ч. ландшафтной географии, должен быть направлен на освоение новых и пограничных областей знания, объектов, решение междисциплинарных проблем, совместное изучение экологии сред, ландшафтов, географических подразделений - территорий, регионов. Возможности эти показаны автором на примере оценки воздействия горнопромышленного комплекса, в области сопряжения минерально-сырьевого природопользования и ландшафтной географии.

\section{БИБЛИОГРАФИЧЕСКИЙ СПИСОК}

1. Антипова А. В. Россия: эколого-географический анализ территории. - Москва-Смоленск: Манджента, 2011. - 384 с.

2. Аржанова В.С., Болдескул А.Г., Кудрявцева Е.П. Проблемы устойчивости геосистем чернопихтово-широколиственных лесов Российского Дальнего Востока // Динамика геосистем и оптимизация природопользования: Мат-лы межд. конф., посв. 105-летию со дня рожд. акад. В.Б. Сочавы. - Иркутск, 2010. - С. 11-13.

3. Аржанова В.С., Елпатьевская В.П., Елпатьевский П. В. Эколого-геохимические аспекты горнопромышленного типа техногенеза (юг Дальнего Востока России) // Ландшафтоведение: теория, методы, региональные исследования, практика: материалы XI международной конференции. - М.: Географический факультет МГУ, 2006. - С. 293-295.

4. Арманд Д.Л. Принципы физико-географического районирования // Изв. АН СССР. Сер. геогр. - 1952. - № 1. - С. 68-82.

5. Арманд Д.Л. Логичность географических классификаций и схем районирования // Развитие и преобразование географической среды. - М: Наука, 1964. - С. 33-53.

6. Арманд А.Д. Самоорганизация и саморегулирование географических систем. - М.: Наука, 1988. - 260 с.

7. Атлас лесов Приморского края. - Владивосток: ДВО РАН 2005. - 76c.

8. Бакланов П.Я., Ганзей С. С., Ермошин В.В. Природнохозяйственное районирование трансграничных территорий // География и природные ресурсы. - 2005. - № 4. - С. 107-114.

9. Безруков Л.А. Континентально-океаническая дихотомия в международном и региональном развитии. - Новосибирск: Акад. Изд-во «Гео», 2008. - 369 с.

10. Белянин П.С. Рельефтно-субстратная основа ландшафтов Приханкайской равнины и ее горного обрамления. // Материалы XIV Совещания географов Сибири и Дальнего Востока. Владивосток: Тихоокеанский институт географии ДВО РАН, Владивосток, 2011. С. $110-112$.

11. Белянина Н.И., Белянин П. С. О развитии палеоландшафтов долины p. Раздольной в раннем неоплейстоцене. // Материалы XIV Совешания географов Сибири и Дальнего Востока. Владивосток: Тихоокеанский институт географии ДВО РАН, Владивосток, 2011. С. 113-114. 
12. Берг Л.С. Климатические пояса земли // Изв. Геогр. инта. - 1925. - Вып. 5. - С. 21-47.

13. Берг Л. С. Ландшафтно-географические зоны СССР. - М.; Л.: Сельхозгис, 1931. - 401 с.

14. Берсенев И.И. Стратиграфия четвертичных отложений Приморья. Инф. сб. ПГУ - 1963. - № 4. - С. 32-34.

15. Болдескул А. Г., Аржанова В.С., Кудрявцева Е.П., Роль растительности в процессах геохимии и функционирования ландшафтов // Материалы XIV Совещания географов Сибири и Дальнего Востока. Владивосток: Тихоокеанский институт географии ДВО РАН, Владивосток, 2011. С. 117-120.

16. Бондарь А.Н. Колмаков П. В. Эколого-экономические аспекты охраны прибрежных вод территорий устойчивого развития // Материалы 3-го Междунар. эколог. форума. Владивосток. 2009. - Владивосток.: Изд.-во Дальневост. ун-та, 2007. - С. 46-48.

17. Булатов В.И., Винокуров Ю.И. Ландшафтная индикация в решении задач природопользования. // Ландшафтная индикация для рационального использования природных ресурсов. - М.: МФГО, 1989. - С. 12-19.

18. Булатов В.И., Винокуров Ю.И., Красноярова Б.А. Программно-целевой подход в изучении природопользования на уровне региона. Территориальные взаимодействия хозяйства и природы. Мат-лы корд. соещания. - М.: ИГАН, 1990. С. 185-197.

19. Булатов В.И. Антропогенная трансформация ландшафтов и решение региональных проблем природопользования (на примере юга Западной Сибири). ДисС. на соиск. уч. степ. доктора географ. наук в форме науч. докл. - Иркутск, 1996. - 63с.

20. Булатов В.И. Российская экология: дифференциация и целостность. Аналитический обзор. ГПНТБ, ИВЭП СО РАН. Серия «Экология», вып. 61. - Новосибирск, - 2001. - 116с.

21.Булатов В.И. Становление и развитие горного ландшафтоведения / В.И. Булатов, Д. В. Черных // Вестн. ВГУ, 2004. № 1. С. $39-42$.

22. Булатов В. И., Ротанова И.Н., Черных Д. В. Ландшафтноэкологический и картографический анализ озерно-бассейновых систем юга Западной Сибири (озера Чаны и Колундинское) // Сибирский экологический журнал, 2005. № 2. С. 175-182.

23. Васильев Н. Г. Долинные широколиственные леса СихотэАлиня. - М.: Наука, 1977. - 117 с.

24. Васильев Н. Г. Ясеневые и ильмовые леса советского Дальнего Востока. - М.: Наука, 1979. - 320 с.
25. Викторов А. С. Рисунок ландшафта. - М.: Мысль, 1986. $180 \mathrm{c}$.

26. Виноградов Б. В. Аэрокосмический мониторинг геосистем с использованием морфологических методов // География и прир. ресурсы, 1998. - № 4. - С. 97-103.

27. Витвицкий Г.Н. Климат // Южная часть Дальнего Востока. - М.: Наука, 1969. - 221 с.

28. Водно-экологические проблемы бассейна реки Амур / Отв. ред. А. Н. Махинов. - Владивосток: ДВО РАН, 2003. - 187 с.

29. Воейков А.И. Климат области муссонов Восточной Азии. СПб.: Изд-во РГО, 1973. 240 с.

30. Волкова Н.И., Жучкова В. К. Новые методы комплексных физико-географических исследований // Четыре измерения ландшафта. Двадцать лет спустя / ред. - сост.: Г.А. Исаченко, А. В. Кушлин, Н. К. Элизбарашвили. - М.: «Алекс», 2006. C. $110-114$.

31. Воробьев Д. Н. Растительный покров южного Сихотэ-Алиня и дикорастущие плодово-ягодные растения в нем // Изв. ДВО АН CCCP. - Cер. бот., № 1. - 1935.

32. Воронов Б.А. К концепции региональной экологической политики // Материалы 2-го Междунар. эколог. форума. Владивосток. 2007. - Владивосток.: Изд.-во Дальневост. ун-та, 2007. C. $20-25$.

33. Воронов Б.А., Шлотгауэр С.Д., Сапожников Т. Г. Биоразнообразие и Красная книга Хабаровского края / Б.А. Воронов. Владивосток; Хабаровск: Дальнаука, 1997. - 99 с.

34. Воскресенский С. С., Сокольский А. М., Белая Н.И. Антропогенное преобразование долин на Дальнем Востоке СССР // Рельеф, климат и деятельность человека. - М.: Наука, 1981. C. 98-105.

35. Ганзей С. С. Трансграничные геосистемы юга Дальнего Востока России и Северо-Востока Китая. - Владивосток, 2004. $230 \mathrm{c}$.

36. Ганешин Г.С. Геоморфология Приморья // Тр. ВСЕГЕИ. Нов.cep. 1957. - T. 4. -135 c.

37. Геоботаническая карта Приморского края. М 1: 500000 / под ред. Б. П. Колесникова, Г.Э. Куренцовой. - М.,1956.

38. Геология СССР. Приморский край. - М: Недра, 1969. Т. 32, ч. 1. -696 с.

39. Герасимов И. П. Экологические проблемы в прошлой, настоящей и будущей географии мира. - М.: Наука, 1985. - 224 с. 
40. Геосистемы Дальнего Востока России на рубеже 20-21 веков: в 3 т. / колл. авторов; под общ. ред. акад. РАН П.Я. Бакланова. Т. 1. Природные системы и их компоненты / колл. авторов: отв. ред. С. С. Ганзей. - Владивосток: Дальнаука, 2008. - 428 с.

41. Говорушко С. М. Экологическое сопровождение хозяйственной деятельности. - Владивосток: Дальнаука, 2003. - 271 с.

42. Говорушко С. М. Геоэкологическое проектирование и экспертиза: учеб. пособие. - Владивосток: Изд-во Дальневост. ун-та, 2009. -388 c.

43. Говорушко С. М. Экологические последствия морской добычи и транспортировки нефти: глобальная ситуация // Материалы 3-го Междунар. эколог. форума. Владивосток. 2008. Владивосток: Изд-во Дальневост. ун-та. 2009. - С. 52-55.

44. Голубева Л. В., Караулова Л.П. Растительность и климатостратиграфия плейстоцена и голоцена юга Дальнего Востока CCСР. - М.: Наука, 1983. - 144 с.

45. Григорьев А.А. Географическая оболочка Земли // Взаимодействие наук при изучении Земли. - М., 1963. - 164 с.

46. Григорьев А.А. О некоторых основных физико-географических закономерностях // Изв. АН СССР. Сер. геогр. и геофиз. 1973. - № 4. - С. 62-68.

47. Гродзинский М.Д. Устойчивость геосистем: теоретический подход к анализу и методы количественной оценки // Изв. АН СССР. Сер. геогр. - 1987. - № 6. - С. 5-15.

48. Дальний Восток - 2: Сборник статей. Отдельный выпуск Горного информационного бюллетеня (науч. - техн. журн.). - М.: Изд-во «Горная книга», 2009. - № 0В5. - 432 с.

49. Деркачева Л.Н., Русанов В.И. Климат Приморского края и его влияние на жизнедеятельность человека. Владивосток. ДВО АН СCCP, 1990. 136 с.

50. Дьяконов К.Н. О законах и закономерностях функционирования ландшафтов // Структура, функционирование, эволюция природных и антропогенных ландшафтов: Материалы докл. 10-й ландш. конф. - СПб.: РГО, 1997. - С. 19-21.

51. Дьяконов К.Н. Взаимодействие структурного, эволюционного и функционального направлений в ландшафтных исследований // Вестн. Моск. ун-та. Сер. 5, геогр. - 2002. - № 1. С. $13-21$.

52. Дьяконов К.Н. Теоретические положения и направления исследований современного ландшафтоведения / К.Н. Дьяконов, Ю. Г. Пузаченко // География, общество, окружающая среда. Т. 2.
Функционирование и современное состояние ландшафтов. М. Городец, 2004. - С. 21-35.

53. Дьяконов К.Н. Ландшафтоведение в современном обшестве и актуальные задачи ландшафтных исследований // Ландшафтоведение: теория, методы, региональные исследования, практика: материалы XI междунар. конф. - М.: Географический факультет МГУ, 2006. - С. 8-13.

54. Добрынин А. П. Дубовые леса российского Дальнего Востока (биология, география, происхождение). - Владивосток: Дальнаука, 2000. - 260 с.

55. Докучаев В. В. Учение о зонах природы. - М.: Географгис, 1948. -64 c.

56. Долговременная программа охраны природы и рационального использования природных ресурсов Приморского края до 2005 года. Ч. 2. - Владивосток: Дальнаука, 1993. - 301 с.

57. Жучкова В.К. Методы комплексных физико-географических исследований / В.К. Жучкова, Э. М. Раковская. М.: Академия, 2004. 368 с.

58. Занин А.А. Климат СССР. Дальний Восток. - Л.: Гидрометеоиздат, 1958. Вып. 8. - 167 с.

59. Зверева В.П. Экологические аспекты гипергенеза и рациональное природопользование // Материалы 2-го междунар. эколог. форума. Владивосток. 2007. - Владивосток: Изд.-во Дальневост. ун-та, 2007. - С. 455-459.

60. Зверева В.П., Кравченко О.Н. Техногенное воздействие горнопромышленного комплекса и его экологические последствия (Дальнегорский район, Приморье) // 5-й науч. сем. «Минералогия техногенеза-2003». РАН, Уральское отделение. - Миасс, 2003. C. $115-221$.

61. Зверева В. П., Костина А. М., Коваль О. В. Горнопромышленная техногенная система Кавалеровского района Дальнего Востока и ее воздействие на экосферу // Дальний Восток-2: Сб. статей. Отдельный выпуск Горного информационного бюллетеня (научно-технического журнала). - М.: Изд-во «Горная книга», 2009. - № OB5. - С. 208-217.

62. Ермошин В.В., Ганзей К. С. Классификация и катографирование ландшафтов Российской части бассейна реки Амур. // Материалы XIV Совешания географов Сибири и Дальнего Востока. Владивосток: Тихоокеанский институт географии ДВО РАН, Владивосток, 2011. С. 19-22. 
63. Иванов Г.И. Почвы Приморья и Приамурья // Агрохимическая характеристика почв СССР, Дальний Восток. - М.: Наука, 1971. - С. 67-71.

64. Иванов Г.И. Почвообразование на юге Дальнего Востока. - М.: Наука, 1976. - 200 с.

65. Ивашинников Ю. К. Палеогеоморфология депрессинных морфоструктур юга Дальнего Востока. - М.: Наука, 1978. - 130 с.

66. Ивашинников Ю. К. Физическая география Восточной Азии: учеб. пособие. - Владивосток: Изд-во Дальневост. ун-та, 2002. -568 c.

67. Ивашинников Ю. К., Короткий А. М. Неотектоника и палеогеография кайнозоя Азиатско-Тихоокеанской переходной зоны. - Владивосток: Изд-во Дальневост. ун-та, 2005. - 390 с.

68. Ивашутина Л.И., Николаев В.А. К анализу ландшафтной структуры физико-географических регионов // Вестн. МГУ. 1969. - № 4. - C.49-59.

69. Ивлев А. М., Крупская Л.Т., Дербенцева А. М. Техногенное загрязнение почв и их восстановление. - Владивосток: Изд-во Дальневост. ун-та, 1998. - 65 с.

70. Ивлев А. М. Особенности структуры почвенного покрова Дальнего Востока // Ноосферные изменения в почвенном покрове: материалы межд. науч.-практ. конф. - Владивосток. Изд-во Дальневост. ун-та, 2007. - С. 55-56.

71. Ивлев А. М., Дербенцева А. М. Деградированные почвы и их рекультивация: уч. пос. - Владивосток: Изд-во Дальневост. ун-та, 2003. - 110 с.

72. Изменение климата и ландшафтов за последние 65 миллионов лет (кайнозой: от палеоцена до голоцена). - М.: ГЕОС, 1999. - 261 с.

73. Исаченко А.Г. Основы ландшафтоведения и физико-географическое районирование. - М.: Высш. шк., 1965. - 312 с.

74. Исаченко А.Г. Методы прикладных ландшафтных исследований. - Л.: Наука, 1980. 222 с.

75. Исаченко А.Г. Оптимизация природной среды (географический аспект). - М.: Мысль, 1980. 264 с.

76. Исаченко А. Г. Ландшафты СССР. Л., 1985. - 320 с.; карт.

77. Исаченко А. Г. (науч. редактор). Ландшафтная карта СССР. Масштаб 1: $4000000,1985$.

78. Исаченко А.Г. Ландшафтоведение и физико-географическое районирование. - М.: Высш. шк., 1991. - 368 с.

79. Исаченко А.Г. Экологическая география России. - СПб.: Изд-во СПбГУ, 2001. - 328 с.
80. Исаченко А. Г. Ландшафтоведение на переходе ко второму столетию своей истории // Ландшафтоведение: теория, методы, региональные исследования, практика: материалы XI междунар. конф. - М.: Географический факультет МГУ, 2006. - С. 3-8.

81. Карта лесов Приморья. Преобладающие лесообразующие породы / Б. С. Петропавловский. М. 1000000. - Владивосток, 2001.

82. Касимов Н.С. Базовые концепции и принципы геохимии ландшафтов // Ландшафтоведение: теория, методы, региональные исследования, практика: материалы XI междунар. конф. - М.: Географический факультет МГУ, 2006. - С. 22.

83. Касимов Н.С., Гаврилова И.Л., Герасимова М.И., Богданова М.Д. Новая ландшафтно-геохимическая карта России для национального атласа // Ландшафтоведение: теория, методы, региональные исследования, практика: материалы XI междунар. конф. - М.: Географический факультет МГУ, 2006. - С. 140-141.

84. Кирпотин С. Н. Ландшафтная экология с основами управления окружающей средой: Учебное пособие -Томск: Томский государственный университет, 2002. - 180 с.

85. Кирпотин С. Н. Ландшафтная экология с основами управления окружающей средой: уч. пос. - 2-е изд., перераб. и доп. Томск: Изд-во Том. ун-та, 2008. - 261 с.

86. Киселева А. Г. Географический анализ прибрежно-морской флоры сосудистых растений Приморского края. // Материалы XIV Совещания географов Сибири и Дальнего Востока. Владивосток: Тихоокеанский институт географии ДВО РАН, Владивосток, 2011. С. $165-168$.

87. Климина Е. М. Опыт ландшафтно-экологического картографирования в Хабаровском крае; основные подходы и перспективы // ГИС для оптимизации природопользования в целях устойчивого развития территории: материалы междунар. конф. Барнаул, 1998. - С. 590-594.

88. Климина Е. М. Ландшафтные комплексы как объекты оценки экологического состояния города (на примере Северного микрорайона) // Историко-культурное и природное наследие Дальнего Востока на рубеже веков: Вторые Гродековские чтения: материалы регион. конф. - Хабаровск, 1999. - С. 338-341.

89. Климина Е. М., Мирзеханова 3.Г., Булгаков В.А. Принципы и методы разработки карты «Хабаровский край. Ландшафты и природные процессы, ограничивающие хозяйственную деятельность» // Регионы нового освоения: состояние, потенциал, перспективы в начале третьего тысячелетия: материалы между- 
нар. науч. конф. - Владивосток; Хабаровск: ДВО РАН, 2002. C. $128-130$

90. Климина Е. М. Методические аспекты оценки и картографирования экологического состояния ландшафтов административного района // География и природные ресурсы. - 2003. № 2. - C. 129-131.

91. Климина Е. М., Остроухов А. В. Изменение ландшафтного разнообразия северного Сихотэ-Алиня под влиянием пирогенной трансформации // Динамика геосистем и оптимизация природопользования: Мат-лы межд. конф. Посв. 105-летию со дня рожд. Акад. Сочавы. - Иркутск, 2010. - С. 110-113.

92. Коновалова Т.И. Геосистемное картографирование // Матлы XIV Совещания географов Сибири и Дальнего Востока. - Владивосток: Дальнаука, 2011. - С. 582-585.

93. Коновалова Т.И. Региональный анализ изменчивости геосистем (на примере юга средней Сибири). Авторф. Дис. на соиск. уч. степ. доктора геогр. наук. - Иркутск, 2006,-43c.

94. Колбовский Е. Ю. Ландшафтоведение: учеб. Пособие для вузов / Е. Ю. Колбовский. - 3-е изд. - М.: Академия, 2008. - 178 с.

95. Коломыц Э.Г. Бореальный экотон и географическая зональность. Атлас-монография. - М.: Наука, 2005. - 390 с.

96. Короткий А. М. Генетические типы современного аллювия рек Южного Приморья // Вопросы геологии и рудоносности Дальнего Востока. - Владивосток, 1965. - С. 121-127.

97. Короткий А. М. Корреляция современного рельефа и осадков для целей палеогеографии (на примере горных стран юга Дальнего Востока). - Владивосток, 1970. -167 с.

98. Короткий А. М. Мерзлотные и нивационные образования в вершинном поясе Сихотэ-Алиня // Климатическая геоморфология Дальнего Востока. - Владивосток: ДВНЦ АН СССР, 1976. - C.100-123.

99. Короткий А. М., Никольская В.В., Скрыльник Г.П. Пространственно-временные закономерности осыпного и курумового морфолитогенеза в условиях муссонного и континентального климата Дальнего Востока // Локальные контрасты в геосистемах. - Владивосток: ДВНЦ АН СССР, 1977. - С. 122-134.

100. Короткий А. М. Палеогеоморфологический анализ рельефа и осадков горных стран (на примере Дальнего Востока). - М.: Наука, 1983. - 246 с.

101. Короткий А. М. Террасовые ряды речных долин СихотэАлиня (условия формирования, возраст и корреляция) // Геоморфология. -2004 . № 1. - С. 65-78.
102. Короткий А. М., Макарова Т. Р. Палеогеографические и геоморфологические аспекты устойчивости геосистем в бассейнах горных рек. - Владивосток: Дальнаука, 2005. - 293 с.

103. Короткий А. М. Рельеф (Приморье) // Геосистемы Дальнего Востока России на рубеже 20-21 веков: в 3 т. / колл. авторов; под общ. ред. академика П.Я. Бакланова. Т. 1. Природные системы и их компоненты / колл. авторов: отв. ред. С. С. Ганзей. Владивосток: Дальнаука, 2008. - С. 95-104.

104. Костенков Н. М., Ознобихин В.И. Оценка почвенных ресурсов Дальневосточного экономического района в рамках их рационального использования и устойчивого развития территории // Ноосферные изменения в почвенном покрове: материалы междунар. науч. - практич. конф. - Владивосток. Изд-во Дальневост. ун-та, 2007. - С.19-27.

105. Кочуров Б. И. Экологические ситуации и прогноз // География и природные ресурсы. - 1992. - № 2. - С. 5-13.

106. Кочуров Б. И. Экологическая карта СССР // Экос. 1991. - C. 34-35.

107. Кочуров Б. И. География экологических ситуаций (экодиагностика территорий). - М., 1997. - 132 с.

108. Крейда Н.А. Почвы хвойно-широколиственных лесов Приморского края. - Владивосток, 1970. - 228 с. (уч. зап. ДВГУ; T. 27, ч. 2)

109. Крупская Л.Т. Охрана и рациональное использование земель на горных предприятиях Приамурья и Приморья. Хабаровск: ДВО РАН; Приамурское географическое общество, 1992. - 175с.

110. Крупская Л.Т., Матвеенко Т.И., Самагин В.Д. Содержание естественных радионуклеидов в Дальневосточных углях и золошлаковых отходах тепловых электростанций (ТЭЦ), 2006. -5 с.

111. Крупская Л.Т. Оценка трансформации экосистем под воздействием горного производства на юге Дальнего Востока / Л.Т. Крупская, Б. Г. Саксин, А. М. Ивлев, М.Б. Бубнова и др. Хабаровск, 2001. - 192 с.

112. Крылов И.И., Коробов В. В. Эрозионные процессы в пределах Приморского края и их современная антропогенная активизация // Мат-лы XIV Совещания географов Сибири и Дальнего Востока. - Владивосток Дальнаука, 2011. - С. 182-184.

113. Кулаков А.П., Худяков Г.И. Геоморфоструктуры Дальнего Востока России // Геосистемы Дальнего Востока России на рубеже 20-21 веков: в 3 т. / колл. авторов; под общ. ред. академика П.Я. Бакланова. Т. 1. Природные системы и их компоненты / 
колл. авторов: отв. ред. С. С. Ганзей. - Владивосток: Дальнаука, 2008. - С. $20-43$.

114. Куликова В. В. Влияние природных и антропогенных процессов на устойчивость геосистем // Динамика геосистем и оптимизация природопользования: Мат-лы межд. конф. Посв. 105-летию со дня рожд. Акад. Сочавы. - Иркутск, 2010. - С. 136-138.

115. Куренцова Г.Э. Растительность Приморского края. - Владивосток: Дальиздат, 1968. - 192 с.

116. Куренцова Г.Э. Естественные и антропогенные смены растительности Приморья и Южного Приамурья. - Новосибирск: Наука, 1973. - 231 с.

117. Ландшафтная карта СССР масштаба 1: 2500000. Министерство геологии СССР. Гидроспецгеология. Отв. ред. И. С. Гудилин. - M, 1980.

118. Легенда к ландшафтной карте СССР масштаба 1: 2500000. Коллектив авторов. - М., 1987. - 340 с.

119. Леса Дальнего Востока / под ред. А. С. Агеенко. - М Лесн. пром-сть, 1979. - 392 с.

120. Ливеровский Ю.А., Колесников Б. П. Природа южной половины советского Дальнего Востока. - М., 1949. - 126 с.

121. Литология и геохимия современных озерных отложений гумидной зоны (на примере оз. Ханка). - М.: Наука, 1979. - 124 с.

122. Лобанова Н.И., Рябчикова Т.Н. О расчетах среднегодового стока на малых реках Приморья // Тр. ДВИИГМИ, 1979. Вып. 76. - С. 62-66.

123. Луценко Т.Н. Особенности условий формирования состава поверхностных вод основных рек Западного Приморья. // Материалы XIV Совещания географов Сибири и Дальнего Востока. Владивосток: Тихоокеанский институт географии ДВО РАН, Владивосток, 2011. С. 192-195.

124. Материалы Всемирной конференции по изменению климата / под ред. Ю.А. Израэль. - М.: Ин-т. глоб. климата и экол. Ростгидромета и РАН, 2003. - 700 с.

125. Махинов А. Н. Закономерности формирования аккумулятивного рельефа в долинах рек // Исследование водных и экологических проблем Приамурья. - Владивосток; Хабаровск: Дальнаука, 1999. - С. 113-117.

126. Махинов А.Н. Современное рельефообразование в условиях аллювиальной аккумуляции. - Владивосток: Дальнаука, 2006. - 232 c.

127. Махинов А.Н., Махинова А.Ф., Шевцов М.Н. Экологический мониторинг горнодобывающих предприятий в Хабаровском крае // Дальний Восток-2: Сб. статей. Отдельный выпуск Горного информационного бюллетеня (науч-техн. журн.). - № 0В5. - М.: Изд-во «Горная книга», 2009 - С. 234-242.

128. Махинова А.Ф. Почвенный покров Нижнего Приамурья. - Владивосток, 1989. - 173 с.

129. Махинова А.Ф. Экологическая устойчивость почвенных комбинаций в районах горнорудного освоения // Регионы нового освоения: состояние, потенциал, перспективы в начале третьего тысячелетия: материалы науч. конф. Хабаровск, 2002. Т. 2. - Владивосток; Хабаровск: Изд-во ДВО РАН, 2002. - С. 17-19.

130. Миллер Ф.Н. Ландшафтные исследования горных и предгорных территорий. - Львов: Выш. Шк, 1974. - 202 с.

131. Мильков Ф.Н. Ландшафтная география и вопросы практики. - М.: Изд-во «Мысль», 1966. - 256 с.

132. Мильков Ф.Н. Словарь-справочник по физической географии. - М.: Мысль, 1970. - 344 с.

133. Мильков Ф.Н. Человек и ландшафты. - М.: Наука, 1973. -224 с.

134. Мильков Ф.Н. Рукотворные ландшафты. - М.: Мысль, 1978. - 86 c.

135. Мильков Ф.Н. Физическая география: учение о ландшафте и географическая зональность. - Воронеж: Изд-во Воронеж. ун-та, 1986. - 326 с.

136. Мирзеханова 3.Г. Эколого-географическая экспертиза территории (взгляд с позиций устойчивого развития). - Хабаровск: Дальнаука, 2000. - 174 с.

137. Мирзеханова 3.Г. Экологические аспекты национальной политики в развитии трансграничных территорий Дальнего Востока (на примере Хабаровского края) // Шестые Гродековские чтения: материалы межрегион. науч.-практ. конф. «Актуальные проблемы исследования Российской цивилизации на Дальнем Востоке / под ред. Е. С. Кошкина. - Хабаровск, 2009. - Т. 6. - С. 13-18.

138. Мирзеханова 3.Г., Булгаков В.А. Хабаровский край. Экологическое состояние территории: Карта и объяснительная записка. - Хабаровск, Владивосток. Дальнаука, 1990. - 19 с.

139. Мирзеханова 3.Г., Булгаков В.А. Современное исследование земель и экологическое состояние территории Амурского района Хабаровского края: Карта. Масштаб 1: 500000. - Хабаровск, 1996.

140. Мирзеханова 3.Г. Эколого-функциональное районирование территории в формировании региональной экологической 
политики // Современные проблемы регионального развития: материалы 2-й междунар. науч. конф. - Биробиджан: ИКАРП ДВО РАН, 2008. - С. 29-30.

141. Михеев В.С. Актуализация методологической основы ландшафтоведения // Структура, функционирование, эволюция природных и антропогенных ландшафтов: Материалы докл. 10-й ландш. конф. - СПб.: РГО, 1997. - С. 7-9.

142. Михеев В.С. Ландшафтно-географическое обеспечение комплексных проблем Сибири. - Новосибирск: Наука, 1987. $208 \mathrm{c}$.

143. Михеев В.С. Ландшафтно-структурный анализ // Человек у Байкала: экологический анализ среды обитания. - Новосибирск: Наука, 1993. - С. 8-39.

144. Михеев В.С. Ландшафтный синтез географических знаний. - Новосибирск: Наука, 2001. - 215 с.

145. Мусорок Г.Г. Лесорастительные свойства почв некоторых типов темнохвойных лесов южного и среднего Сихотэ-Алиня: автореф. дис... канд. геогр. наук. - Хабаровск, 1971. - 42 с.

146. Наумов Ю.А. Антропогенез и экологическое состояние геосистем прибрежно-шельфовой зоны залива Петра Великого Японского моря / гл. ред. Б.И. Кочуров: Владивосток: Дальнаука, 2006. - 298 c.

147. Николаев В.А. Концепция агроландшафта // ВесТ. МГУ. Cep. 5-1987. - № 2. - C. 22-27.

148. Николаев В.А. Ландшафтоведение: Эстетика и дизайн. М. Аспект Пресс, 2003. - 176 с.

149. Никольская В. В. Палеогеография геоморфологического этапа и современные рельефообразующие процессы // Южная часть Дальнего Востока. Природные условия и естественные ресурсы СССР. - М.: Наука, 1969. - С. 49-66.

150. Никольская В.В. О естественных тенденциях развития физико-географических провинций юга Дальнего Востока. - Новосибирск: Наука, 1974. - 127 с.

151. Осипов С.В. Зоны и типы поясности растительности // Геосистемы Дальнего Востока России на рубеже 20-21 веков: в 3 т. / колл. авторов; под общ. ред. акад. П.Я. Бакланова. Т. 1. Природные системы и их компоненты / колл. авторов: отв. ред. С. С. Ганзей. - Владивосток: Дальнаука, 2008. - С. 203.

152. Охрана ландшафтов (Толковый словарь) / под ред. В. С. Преображенского. - М.: Прогресс, 1982. - 272 с.

153. Петлин В.Н. Современное состояние, проблемы и перспективы развития ландшафтоведения // Ландшафтоведение: теория, методы, региональные исследования, практика: материалы XI Междунар. конф. - М.: Геогра фический факультет МГУ, 2006. - C. 23-25.

154. Петренко В.С. Морфодинамика техногенных берегов Приморья // Материалы XIV Совещания географов Сибири и Дальнего Востока. Владивосток: Тихоокеанский институт географии ДВО РАН, Владивосток, 2011. С. 233-234.

155. Пичугина Н. В. Ландшафтоведение. Словарь терминов. Соратов: ИЦ «Наука», 2010. - 103 с.

156. Платонова С.А. К вопросу о территориальной организации природопользования в Приморском крае // Региональная политика России в современных социально-экономических условиях: географические аспекты // Материалы IX научного совещания по прикладной географии. - Иркутск: Изд-во ИГ СО РAH, 2009. - С. 155-156.

157. Плюснин В.М. Ландшафтный анализ горных территорий. - Иркутск: Изд-во Ин-та геогр. СО РАН, 2003. - 257 с.

158. Плюснин В.М. Картографирование и районирование геосистем / В. М. Плюснин, И.Н. Биличенко, М.В. Загорская и др. // Географические исследования Сибири. Структура и динамика геосистам.Новосибирск: Академ. изд-во «Гео», 2007. Т. 1. C. $72-109$.

159. Почвенная карта Приморского края. М 1: 500000 / под ред. Г. И. Иванова. - Хабаровск: ГУГК, 1983.

160. Преображенский В.С. Экологические карты (содержание, требования) // Изв. АН СССР. Сер. геогр. - 1990. - № 6. C. $121-124$.

161. Преображенский В.С., Александрова Т.Д. Новое слово о новом в семействе наук // Изв. РАН. Сер. геогр. - 1995. № $1 .-$ С. $138-140$.

162. Приображенский Б. В., Жариков В. В., ДубейковскийЛ.В. Основы подводного ландшафтоведения (Управление морскими экосистемами). Владивосток; Дальнаука, 2000. 352 с.

163. Пузаченко Ю. Г., Молчанов Г.С., Олещенко Г. М., Хомский П.А. Измерение параметров структуры ландшафта по аэроснимку // Структура, функционирование, эволюция природных и антропогенных ландшафтов: материалы докл. 10-й ландш. конф. - СПб.: РГО, 1997. - С. 84-86.

164. Пшеничников Б.Ф., Пшеничникова Н.Ф. Почвы Дальнего Востока // Геосистемы Дальнего Востока России на рубеже 20-21 веков: в 3 т. / колл. авторов; под общ. ред. акад. 
П.Я. Бакланова. Т. 1. Природные системы и их компоненты / колл. авторов: отв. ред. С. С. Ганзей. - Владивосток: Дальнаука, 2008. - C. $144-172$.

165. Пшеничников Б. Ф. Континентально-приокеанические буроземы, их развитие и эволюция (на примере япономорского побережья): афтореф. Дис. ... д-ра биол. наук. Владивосток, 1988. - 39 c.

166. Ресурсы поверхностных вод СССР. Дальний Восток. Л.: Гидрометеоиздат, 1972. - Т. 18, вып. 3. - 627 с.

167. Ретеюм А. М., Дьяконов К.Н., Куницын Л.Ф. Взаимодействие техники с природой и геотехнические системы // Изв. АН СССР. Сер. Геогр. - 1972. - № 4. - С. 46-55.

168. Саушкин Ю. Г. Культурный ландшафт // Вопр. Географии. - 1946. - Вып. 1. - С. 97-106.

169. Свинухов Г.И., Воробьева Т.Ф. К вопросу об экстремальности месячных сумм осадков на территории Приморского края, Сахалина и Камчатки // Тр. ДВНИИГМИ, вып. 102. - Л.: Гидрометеоиздат, 1983. - С. 40-47.

170. Семенов Ю.М. О фундаментальной и прикладной составляющих комплексной физической географии // Динамика геосистем и оптимизация природопользования: Мат-лы межд. конф. посв. 105-летию со дня рожд. Акад. Сочавы. - Иркутск, 2010. - C. $198-210$.

171. Семенов Ю. М., Снытко В.А., Суворов Е.Г., Плюснин В. М., Биличенко И.Н., Загорская М.В. Ландшафтное разнообразие: теория, методы и некоторые результаты изучения // География и природные ресурсы. - 2004. - № 3. - С. 5-12.

172. Сергеенко В.И. Научные достижения ДВО РАН в сфере предупреждения и ликвидации чрезвычайных экологических ситуаций // Материалы 2-го Междунар. эколог. форума. Владивосток. 2007. - Владивосток.: Изд.-во Дальневост. ун-та, 2007. - С. 32-38.

173. Скрыльник Г.П., Скрыльник Т.А. Характеристика континентальности Дальнего Востока // География и палеогеография климатоморфогенеза. Владивосток: ДВО АН СССР, 1976. C. $122-128$.

174. Скрыльник Г.П. Ведущие факторы развития рельефа Дальнего Востока и его место в общем климоморфогенезе материков Северного полушария // Исследование глобальных факторов климоморфогенеза Дальнего Востока. - Владивосток: ТИГ ДВНЦ AH CCCP, 1979. - C. 7-31.

175. Скрыльник Г.П. Взаимодействия факторов и процессов в организации геосистем и устойчивое развитие // Рельефоо- бразующие процессы: теория, практика, методы исследования (Материалы 28-го Пленума Геомофологич. комиссии РАН). Новосибирск: ГК РАН; ИГ СО РАН, 2004. - С. 247-249.

176. Скрыльник Г. П. Развитие геосистем, пространство и время // Новые и традиционные идеи в геоморфологии. - М.: МГУ РФФИ, 2005. - С. 549-554 (5-е Щукинские чтения: тр.).

177. Скрыльник Г.П. Географические проблемы устойчивого развития зон влияния «Линейные сооружения - природная среда» // Материалы XIV Совещания географов Сибири и Дальнего Востока. Владивосток: Тихоокеанский институт географии ДВО РАН, Владивосток, 2011. С. 535-538.

178. Снытко В.А. История исследований ландшафтов // Ландшафтоведение: теория, методы, региональные исследования, практика: материалы XI Междунар. конф. - М.: Географический факультет МГУ, 2006. - С. 49-50.

179. Солнцев Н.А. Учение о ландшафте (избранные труды). М.: Изд-во МГУ, 2001. - 384 с.

180. Сочава В.Б. Опыт деления Дальнего Востока на физикогеографические области и провинции // Докл. Ин-та географии Сибири и Дальнего Востока. - 1962. - Вып. 1. - С. 23-33.

181. Сочава В. Б. Ботанико-географические соотношения в бассейне Амура // Амурская тайга (комплексные ботанические исследования). - Л.: Наука, 1969. - С. 5-15.

182. Сочава В.Б. География и экология // Материалы V съезда ГО СССР. - Л., 1970. - С. 12-18.

183. Сочава В.Б. Ведение в учение о геосистемах. - Новосибирск: Наука, 1987. - 320 с.

184. Сочава В.Б. Избранные труды. Теоретическая и прикладная география. - Новосибирск: Наука, 2005. - 288 с.

185. Справочник по климату СССР- Л.: Гидрометеоиздат, 1966. - Вып. 26. - 220 с.

186. Справочник по климату СССР. - Л.: Гидрометеоиздат, 1967. - Вып. 26. - 217 с.

187. Справочник по климату СССР. Л.: Гидрометеоиздат, 1968. Вып. 26. 238 с.

188. Справочник по климату СССР. - Л.: Гидрометеоиздат, 1969. - Вып. 26. - 196 с.

189. Справочник по климату СССР. - Л.: Гидрометеоиздат, 1971. - Вып. 26. - 464 с.

190. Справочник по климату СССР. - Л.: Гидрометеоиздат, 1966. - Вып. 25. ч. 2. - 312 с. 
191. Справочник по климату СССР. - Л.: Гидрометеоиздат, 1966. - Вып. 25, ч. 4. - 315 с.

192. Справочник по климату СССР. Приморский край. - Л.: Гидрометеоиздат, 1990. - Вып. 26. - 190 с.

193. Старожилов В.Т. Генетические типы месторождений, проявлений апатита на территории Приморья // Геология и магматизм Дальнего Востока. Владивосток: ДВО АН СССР, 1980. C. $87-94$.

194. Старожилов В.Т. К вопросу об апатитоносности Приморья / В. С. Коренбаум, Э.Л. Школьник, Б, Л, Залишак, В. В. Чернобровкин, В.Т. Старожилов. Фосфаты Дальнего Востока. ДВО АН СССР. - Владивосток, 1980. - С. 74-82.

195. Старожилов В.Т. Потенциально фосфоритоносные формации Приморья // Геохимия и петрохимия осадочных комплексов Дальнего Востока. Владивосток: ДВО АН СССР, 1980. - С. 56-64.

196. Старожилов В.Т. Уровни фосфоритонакопления Приморья // Геохимия и петрохимия осадочных комплексов Дальнего Востока. Владивосток: ДВО АН СССР, 1980. - С. 82-88.

197. Старожилов. В.Т. Офиолитовый шов Приморья. ВИНИТИ. М. № 3508-В 87, 1987. 16 с.

198. Старожилов В.Т. Офиолитовый шов Приморья // Материалы 3-й Тихоокеанской школы по морской геологии, геофизики и геохимии. - Южно-Сахалинск: ДВО АН СССР, 1987. С. $112-116$.

199. Старожилов В.Т. Прогнозная оценка эндогенной фосфатоносности базит-гипербазитовых комплексов Приморья и рекомендации по направлению дальнейших работ // ВИНИТИ. М. № 3428-B87, 1987. 32 с.

200. Старожилов. В.Т. Апатитоносность и петрологические особенности фанерозойских базит-гипербазитовых комплексов Приморья. - Владивосток: ДВО АН СССР, 1988. - 240 с.

201. Старожилов В.Т. Комплексная оценка рудоносности апатитсодержащих пироксенитов массива ультраосновных-щелочных пород на Дальнем Востоке / Э.Л. Школьник, В. И. Ничепуренко, Л.А. Саматова, В. В. Голозубов, В.Т. Старожилов. Природа базитов Востока Азии. - Владивосток: ДВО АН СССР, 1989. С. $42-47$

202. Старожилов В.Т. Районирование Приморского края по природным условиям поисков месторождений полезных ископаемых // Материалы 20-го пленума геоморфологической комиссии АН СССР. - Владивосток: ДВО АН СССР, 1989. - С. 82-83
203. Старожилов В.Т. Базиты офиолитовых зон ВосточноСахалинских гор // Тихоокеанская геология. - 1990. - № 6. C. $36-43$.

204. Старожилов В. Т. Структурно-тектоническое районирование Пионерско-Шельтинской зоны Восточно-Сахалинских гор // Тихоокеанская геология. - 1990. - № 3. - С. 90-96.

205. Старожилов В.Т. Структурно-петрохимические особенности и возможная платиноносность пород Южно-Шмидтовского аллохтона // Тихоокеанская геология. -1990. - № 4 - С. 90-96.

206. Старожилов В.Т. Районирование Приморского края по природным условиям поисков полезных ископаемых // Вопросы географии и геоморфологии советского Дальнего Востока. - Владивосток: Изд-во Дальневост. ун-та, 1991. - С.175-190.

207. Старожилов В.Т. Геодинамическая эволюция зон перехода северо-востока Азии к Тихоокеанской плите // Гидрометеорологические и географические исследования на Дальнем Востоке: материалы 5-й юбилейной научн. конф. «К всемирным дням воды и метеорологии». - Владивосток, 2004. - С.85-88.

208. Старожилов В.Т. Геохимия и рудоносность базитов и гипербазитов фундамента ландшафтов складчатых областей зоны перехода северо-востока Азии к Тихоокеанской плите // Дальний Восток России: География. Гидрометеорология. Геоэкология: материалы шестой научной конференции. «К Всемирным дням воды и метеорологии». - Владивосток, 2005. - Владивосток: Издво Дальневост. ун-та, 2005. - С. 174-179.

209. Старожилов В.Т., Зонов Ю. Б. Региональное среднемасштабное картирование, систематика и классификация ландшафтных геосистем Приморского края // Ландшафтоведение: теория, методы, региональные исследования, практика: материалы XI Междунар. конф. - М.: Географический факультет МГУ, 2006. C 244-246.

210. Старожилов В.Т. Структура и пространственная организация ландшафтов и эколого-ландшафтоведческий анализ приокеанских Дальневосточных территорий (на примере Приморского края) // Материалы междунар. науч.-практ. конф. «Экологические проблемы использования прибрежных морских акваторий» - Владивосток: Изд-во Дальневост. ун-та, 2006. - С. 182-185.

211. Старожилов В.Т., Зонов Ю. Б. Ландшафтный потенциал природопользования и качества среды обитания человека // Материалы 1-й междунар. науч. конф. «Современные проблемы регионального развития». Биробиджан, 2006. - Хабаровск: ДВО PAH, 2006. - C. 137-138. 
212. Старожилов В.Т., Зонов Ю. Б. Ландшафтные предпосылки устойчивого развития территорий // Природа без границ: материалы 1-го междунар. эколог. форума. Ч. 2. Владивосток, 2006. Владивосток: Изд-во Дальневост. ун-та, 2006. - С 261-265.

213. Старожилов В.Т. Региональное среднемасштабное картирование, структура и пространственно-временная организация ландшафтных геосистем Приморья // Морское картографирование на Дальнем Востоке: Вторые Муравьевские чтения: материалы науч.-практ. конф. - Владивосток: ОИАК, 2006. - С. 50-55.

214. Старожилов В.Т., Зонов Ю.Б. Карта типов ландшафтов масштаба 1:1000000 Приморского края // Электронные карты Приморского края. - Владивосток: ТИГ ДВО РАН, 2006.

215. Старожилов В. Т., Зонов Ю. Б. Карта физико-географического районирования масштаба 1:1000000 Приморского края // Электронные карты Приморского края. - Владивосток: ТИГ ДВО РАН, 2006.

216. Старожилов В.Т., Ивлиев А. М., Дербенцева А. М. Науки о Земле: учеб. пособие. - Владивосток: Изд-во Дальневост. ун-та, 2006. - 105 c.

217. Старожилов В.Т. Структура и пространственная организация ландшафтов приокеанских Дальневосточных территорий (на примере Приморского края) // Дальний Восток России: География. Гидрометеорология. Геоэкология: материалы 7-й науч. конф. «К Всемирным дням воды и метеорологии». Владивосток, 2006. - Владивосток: Изд-во Дальневост. ун-та, 2006. - С. 83-85.

218. Старожилов В.Т., Зонов Ю. Б. Региональное формирование ландшафтных геосистем Приморского края // Дальний Восток России: География. Гидрометеорология. Геоэкология: материалы 7-й науч. конф. «К Всемирным дням воды и метеорологии». Владивосток, 2006. - Владивосток: Изд-во Дальневост. ун-та, 2006. - С. 83-85.

219. Старожилов В.Т. Речные и денудационные системы рыхлого фундамента ландшафтов Дальневосточных территорий (на примере Приморского края) / А. М. Дербенцева, А. И. Степанова, В. Т. Старожилов: материалы 22-го пленарного совещ. межвуз. науч.-координац. совета по проблеме эрозионных русловых и устьевых процессов. - Новочеркасск, 2007. - С. 92-93.

220. Старожилов В.Т. Структура и пространственная организация ландшафтов и природо-, ресурсопользование юга Дальнего Востока (на примере Приморского края) // Природа без границ: материалы 2-го Междунар эколог. форума. Владивосток, 2007. Владивосток: Изд-во Дальневост. ун-та, 2007. - С. 174-176.
221. Старожилов В.Т. Ноосферные проблемы, структура и пространственная организация Дальневосточных территорий (на примере Приморского края) // Ноосферные изменения в почвенном покрове: материалы междунар. науч.-практ. конф. «Ноосферные изменения в почвенном покрове.»- Владивосток: Изд-во Дальневост. ун-та, 2007. - С. 31-37.

222. Старожилов В.Т. Картирование ландшафтов и геодинамическая эволюция фундамента Дальневосточных территорий // Ноосферные изменения в почвенном покрове: материалы междунар. науч.-практ. конф. «Ноосферные изменения в почвенном покрове» - Владивосток: Изд-во Дальневост. ун-та, 2007. - С. 174-178.

223. Старожилов В.Т. Проблема ресурсопользования, структура и пространственная организация ландшафтов приокеанских Дальневосточных территорий // Науки о Земле и отечественное образование: история и современность: материалы ВсероС. науч.практ. конф., посвященной памяти академика РАО А. В. Даринского. - СПб.: Изд-во РГПУ им. А. И. Герцена, 2007. - С. 309-312.

224. Старожилов В.Т. Структура и пространственная организация ландшафтов и использование природных ресурсов территорий // Материалы междунар. науч.-практ. конф. «География, природные ресурсы и туристско-рекреационный потенциал Балтийского региона». - Великий Новгород: Изд-во Нов. ГУ им. Ярослава Мудрого, 2007. - С. 205-209.

225. Старожилов В.Т. Региональные особенности компонентов и факторов структуры и организации ландшафтов юга Дальнего Востока (на примере Приморского края): монография. - Владивосток: Изд-во Дальневост. ун-та, 2007. - 114 с.

226. Старожилов В.Т. Структура и пространственная организация ландшафтов юга Дальнего Востока (на примере Приморского края): монография. - Владивосток: Изд-во Дальневост. ун-та, 2007. - 308 c.

227. Старожилов В.Т. Особенности свойств почв в ландшафтных зонах затопления паводковыми водами (на примере Приморья): учебн. пособие / А. М. Дербенцева, В.И. Ознобихин А.И. Степанова, В.Т. Старожилов, А.А. Бессарабова. - М.: ВНТИЦ, 2007. - № 50200700723. - 121 с.

228. Старожилов В.Т. Учебно-методический информационный комплекс «Ландшафтоведение». - М.: ВНТИЦ, 2007. № 50200700536 . -56 c.

229. Старожилов В.Т. Учебно-методический информационный комплекс «Геология». - М.: ВНТИЦ, 2007. - № 50200700534. - 62 с. 
230. Старожилов В.Т. Учебно-методический информационный комплекс «Геохимия ландшафта». - М.: ВНТИЦ, 2007. № 50200700535 . $-56 \mathrm{c}$.

231. Старожилов В.Т. Учебно-методический информационный комплекс «Минералогия». - М.: ВНТИЦ, 2007. № 50200700537 . -58 c.

232. Старожилов В.Т. Карта ландшафтов Приморского края масштаба 1:500000. М.: ВНТИЦ, 2007. - № 50200702556.

233. Старожилов В.Т. Структура и пространственная организация ландшафтов юга Дальнего Востока (на примере Приморского края). Объяснительная книга, ч. 2, к карте ландшафтов Приморского края масштаба 1:500000. - М.: ВНТИЦ, 2008. № 50200800309 . - 308 c.

234. Старожилов В.Т. Региональные компоненты и факторы структуры и пространственной организации ландшафтов юга Дальнего Востока (на примере Приморского края): учеб. пособие. М.: - ВНТИЦ, 2008. - № 50200800311. - 114 c.

235. Старожилов В.Т., Зонов Ю. Б. Карта ландшафтов Приморского края масштаба 1:3000000 // Атлас Приморского края.: 2-е изд. исправл. и доп. - Владивосток: ТИГ ДВО РАН, 2008.

236. Старожилов В.Т., Зонов Ю. Б. Карта физико-географического районирования масштаба 1:8000000 Приморского края // Атлас Приморского края. 2-е изд. исправл. и доп. - Владивосток: ТИГ ДВО РАН, 2008.

237. Старожилов В.Т. Ландшафт, денудация, транзит склоновых отложений и поиски минерально-сырьевых ресурсов юга Дальнего Востока (на примере Приморского края) / А. М. Дербенцева, Л, Т. Крупская, В.Т. Старожилов // Материалы 23-го пленарного совещ. межвуз. науч.-координац. совета по проблеме эрозионных русловых и устьевых процессов. - Калуга, 2008. C $110-111$.

238. Старожилов В.Т., Дербенцева А. М., Ознобихин В.И., Крупская Л.Т., Степанова А.И. Ландшафтные условия развития эрозионно-денудационных процессов юга Дальнего Востока: монография. - Владивосток: Изд-во Дальневост. ун-та, 2008. $100 \mathrm{c}$.

239. Старожилов В.Т. К проблеме природопользования и экологии территорий: ландшафтная карта Приморского края масштаба 1:500000 // Современные проблемы регионального развития: материалы 2-й междунар. науч. конф. - Биробиджан: ИКАРП ДВО РАН, 2008. - С. 41-42.
240. Старожилов В.Т. К проблеме природопользования: ландшафтно-картографические основы применения методов поисков минерально-сырьевых ресурсов юга Дальнего Востока (на примере Приморского края) // Природа без границ: материалы 3-го междунар. эколог. форума. - Владивосток: Изд-во Дальневост. унта, 2008. - С. 113-116.

241. Старожилов В.Т. Типы, классы, роды ландшафтов юга Дальнего Востока (на примере Приморского края) // Дальний Восток России: География. Гидрометеорология. Геоэкология.: материалы 7-й науч. конф. «К Всемирным дням воды и метеорологии» Владивосток, 2008. - Владивосток: Изд-во Дальневост. унта, 2008. - С. 99-101.

242. Старожилов В. Т. Виды ландшафтов юга Дальнего Востока (на примере Приморского края) // Дальний Восток России: География. Гидрометеорология. Геоэкология: материалы 7-й науч. конф. «К Всемирным дням воды и метеорологии» Владивосток, 2008. - Владивосток: Изд-во Дальневост.ун-та, 2008. - С. 101-104.

243. Старожилов В.Т. Карта ландшафтов Приморского края масштаба 1: 1000000. - Владивосток: Изд-во Дальневост. ун-та, 2009.

244. Старожилов В.Т. Ландшафты Приморского края масштаба 1: 500000 (Объяснительная записка к карте масштаба 1: 500000). Владивосток: Изд-во Дальневост. ун-та, 2009. - 368 с.

245. Старожилов В.Т. Денудационные процессы в ландшафтах и геоэкологические предпосылки техногенных изменений: монография / В.Т. Старожилов, Л.Т. Крупская, А. М. Дербенцева, А. А. Черенцова, А. И. Степанова, В.И. Ткаченко, Т. И. Матвеенко. - Владивосток: Изд-во Дальневост. ун-та, 2009. - 137 с.

246. Старожилов В.Т. Гидромелиорации и влияние их на водный режим и твердый сток водосборов: монография / К. П. Березников, Н.А. Сакара, Л. Т. Крупская, А. М. Дербенцева, В.Т. Старожилов, А.И. Степанова, О. В. Нестерова, В.И. Ознобихин. - Владивосток: Изд-во Дальневост. ун-та, 2009. - 92 с.

247. Старожилов В.Т. К проблеме природопользования: оптимизация поисков минерально-сырьевых ресурсов юга Дальнего Востока (на примере Приморского края) // Современные геофизические и географические исследования на Дальнем Востоке России: материалы 9-й науч. конф. «К Всемирным дням воды и метеорологии» - Владивосток, 2009. - Владивосток: Изд-во Дальневост. ун-та, 2010. - С. 152-155.

248. Старожилов В.Т. Эколого-ландшафтный подход к промышленным территориям юга Дальнего Востока // Современные 
геофизические и географические исследования на Дальнем Востоке России: материалы 9-й науч. конф. «К Всемирным дням воды и метеорологии» - Владивосток, 2009. - Владивосток: Изд-во Дальневост. ун-та, 2010. - С. 155-159.

249. Старожилов В. Т., Дербенцева А. М., Нестерова О. В., Ткаченко В.И., Евсеев А. Б. Картографический эколого-ландшафтный подход в оптимизации природопользования // Горный информационно-аналити-ческий бюллетень. Отдельный вып. 5. Дальний Восток-2. - М.: Изд-во «Горная книга», 2009. C. $271-278$.

250. Старожилов В.Т., Крупская Л. Т., Дербенцева А. М. Структура и организация ландшафтов юга Дальнего Востока и поиски минерально-сырьевых ресурсов // Горный информационно-аналитический бюллетень. Отдельный вып. 4. Дальний Восток-1. М.: Изд-во «Горная книга», 2010. - С. 430-441.

251. Старожилов В.Т. Ландшафтное картографирование, структура и организация ландшафтов Дальневосточных территорий (на примере Приморского края) // Изв. РАН, сер. геогр. 2010. - № 2. - С. 106-113.

252. Старожилов В.Т. Обеспечение зкологической безопасности источников экологического риска на оловорудных предприятиях юга Дальнего Востока / Л.Т. Крупская, Н.И. Грехнев, В. П. Зверева, А. Г. Новороцкая, А. М. Дербенцева, В. Т. Старожилов. // Вестн. РУДН. Сер. «Экология и безопасность жизнедеятельности». - 2009. № 4. - С. 81-88.

253. Старожилов В.Т. Экологические аспекты и картографоландшафтный подход в формировании региональной экологической политики на территории стран АТЭС // Материалы IX науч. сов. по прикладной географии. - Иркутск: Изд-во Ин-та географии им. В.Б. Сочавы СО РАН, 2009. - С. 180-182.

254. Старожилов В.Т. Эколого-ландшафтный подход в формировании региональной экологической политики на территории стран АТЭС // Материалы науч.-практ. конф. «6-е Гродековские чтения». Хабаровск, 2009. - Хабаровск, 2009. - С. 24-27.

255. Старожилов В.Т. Геоэкология ландшафтов зоны влияния теплоэлектростанции: монография / В.Т. Старожилов, Т.И. Матвеенко, Л. Т. Крупская, В.Н. Пилипушка, А. М. Дербенцева, И. В. Коробова. - Владивосток: Изд-во Дальневост. ун-та, 2009. - 108 c.

256. Старожилов В.Т. Геоэкология минерально-сырьевого природопользования ландшафтов юга Дальнего Востока: монография 274
/ В. Т. Старожилов, А. В. Леоненко, Л. Т. Крупская, А. М. Дербенцева. - Владивосток: Изд-во Дальневост. ун-та, 2009. - 88 с. 257. Старожилов В.Т., Зонов Ю. Б. Исследование ландшафтов Приморского края для целей природопользования // География и природные ресурсы. - 2009. - № 2. - С. 94-100.

258. Старожилов В. Т. Человек и природа в социокультурном измерении: актуальные социально-экологические проблемы населения горняцких поселков / А. В. Леоненко, В. Т. Старожилов // Горный информационно-аналитический бюллетень. Отдельный вып. 5. Дальний Восток-2. - М.: Изд-во «Горная книга», 2009. C. $353-362$.

259. Старожилов В.Т. Процессы механической деградации почв в ландшафтах Приморья: монография / А. Б. Евсеев, В.Т. Старожилов, В.И. Ткаченко, А. М. Дербенцева, А. И. Степанова. - Владивосток: Изд-во Дальневост. ун-та, 2009. - 88 с.

260. Старожилов В.Т., Дербенцева А. М., Евсеев А. Б., Крупская Л.Т. Техногенные изменения ландшафтов, обусловленные промышленным производством в Приморском крае // Экологические системы и приборы. - 2009. - № 6. - С. 52-55.

261. Старожилов В.Т. Ландшафтное районирование Приморского края // Вестн. ДВО РАН. - 2010. - № 3. - С. 107-112.

262. Старожилов В.Т., Дербенцева А. М., Пуртова Л.Н., Степанова А.И., Сакара Н.А., Ткаченко В.И. Ирригационная эрозия почв в условиях муссонного климата: учеб. пособие. - Владивосток: Изд-во Дальневост. ун-та, 2010. - 120 с.

263. Старожилов В.Т. Эрозионные процессы в ландшафтах зон паводочного затопления: монография / А. М. Дербенцева, В. Т. Старожилов, А.И. Степанова, В. Н. Пилипушка, А. В. Назаркина. - Владивосток: Изд-во Дальневост. ун-та, 2010. - 120 с.

264. Старожилов В.Т. Гранулометрический состав нерусловых и русловых водных потоков водосборного бассейна Японского моря: монография / А. М. Дербенцева, А. И. Степанова, О. В. Нестерова, Т.И. Матвеенко, В.А. Семаль, В.Т. Старожилов. - Владивосток: Изд-во Дальневост. ун-та, 2010. - 120 с.

265. Старожилов В.Т. Особенности химической деградации почв в ландшафтах юга Дальнего Востока: монография / Е. К. Папынов, А. М. Дербенцева, Л.П. Майорова, В. Г. Трегубова, В.Т. Старожилов, А. В. Назаркина, Т.И. Матвеенко, Л. Г. Пилипушка, В. Н. Пилипушка. - Владивосток: Изд-во Дальневост. унта, 2010. - $130 \mathrm{c}$.

266. Старожилов В.Т. Эколого-ландшафтный подход в формировании программы действий по повышению эффективности 
развития туризма // Туризм в Приморском крае: региональные особенности и перспективы развития.: материалы междунар. науч.-практ. конф. г. Владивосток 2009. - Владивосток: Изд-во Дальневост. ун-та, 2009. - С. 76-79.

267. Старожилов В.Т. Геоэкология ландшафтной зоны влияния отходов переработки оловорудного сырья в бассейне р. Амур: монография / Растина Н. К., Крупская Л.Т., Нестерова О.В., Морин В.А., Старожилов В.Т., Крупский А. В. - Владивосток: Изд-во Дальневост. ун-та, 2010. - 204 с.

268. Старожилов В.Т. Почвы ландшафтов Приморья (Рабочая классификация): учебно-методическое пособие / Костенков Н. М., Нестерова О. В., Пуртова Л.Н., Дербенцева А. М., Крупская Л.Т., Назаркина А. В., Пилипушка В.Н., Семаль В.А., Старожилов В.Т. - Владивосток: Изд-во Дальневост. федерал. ун-та, 2011. - 112 с.

269. Старожилов В.Т. Общее ландшафтоведение и использование ландшафтного подхода в экологическом мониторинге природопользования: курс лекций / Старожилов В. Т. - Владивосток: Изд-во Дальневост. федерал. ун-та, 2011. - 286 с.

270. Старожилов В.Т. Ландшафты Приморского края и использование ландшафтного подхода в оценке экологических проблем минерально-сырьевого природопользования: монография / Старожилов В. Т. - Владивосток: Изд-во Дальневост. федерал. ун-та, 2011. - 228 с.

271. Старожилов В.Т. Ландшафтный мониторинг в обеспечении экологической безопасности районов минерально-сырьевого природопользования (на примере угольного и горнорудного производства Приморья) // Материалы XIV Совещания географов Сибири и Дальнего Востока. Владивосток: Тихоокеанский институт географии ДВО РАН, Владивосток, 2011. С. 545-549.

272. Степанова А. И., Дербенцева А. М., Крупская Л.Т. Оценка экологического состояния почв эрозионно-русловых систем юга Дальнего Востока: учеб. пособие. - Владивосток: Изд-во Дальневост. ун-та, 2006. - 80 с.

273. Тикунов В.С. Классификации в географии (опыт формальных классификаций). - Москва - Смоленск: Изд-во СГУ, 1997. - 367 c.

274. Урусов В.М., Чипизубова М.Н. Общие закономерности географического распределения формаций и типов растительности // Геосистемы Дальнего Востока России на рубеже 20-21 веков: в 3 т. / колл. авторов; под общ. ред. акад. П.Я. Бакланова. 276
T. 1. Природные системы и их компоненты / колл. авторов: отв. ред. С. С. Ганзей. - Владивосток: Дальнаука, 2008. - С. 203-212.

275. Урусов В. М., Варченко Л.И. О перспективах ландшафтного дизайна в Приморье и на Дальнем Востоке России в разных вариантах рельефа и климата. // Материалы XIV Совещания географов Сибири и Дальнего Востока. Владивосток: Тихоокеанский институт географии ДВО РАН, Владивосток, 2011. С. 268-271.

276. Фадеева Н.А. Подходы к определению количественных характеристик при анализе пространственной структуры ландшафта // Современные проблемы природного районирования. М.: ИГ АН СССР, 1975. - С. 123-131.

277. Физико-географическое районирование СССР. - М., 1968. - 525 c.

278. Хабаровский край. Ландшафты и природные процессы. осложняющие хозяйственную деятельность / Е. М. Климина, 3. Г. Мирзеханова, В.А. Булгаков, Л.А. Шаров, А. В. Харченко. Масштаб 1: 2500000. - Хабаровск: ИЭИ ДВО РАН, 2003.

279. Хрисанов В.Р., Сиакин В.В. Динамика ландшафта и экзодинамические системы // Структура, функционирование, эволюция природных и антропогенных ландшафтов: материалы докл. 10-й ландш. конф. - СПб.: РГО, 1997. - С. 109-110.

280. Христофорова Н. К. Экологические проблемы региона: Дальний Восток - Приморье: уч. пос. - Владивосток; Хабаровск: Хабаровск. кн. изд-во, 2005. - 304 с.

281. Хромых О.В., Хромых В. В. Ландшафтный анализ Нижнего Притомья на основе ГИС: естественная динамика долинных геосистем и их изменения в результате антропогенного воздействия. Томск: Изд-во НТЛ, 2011. - 160 с.: ил.

282. Черных Д.Л., Булатов В.И. Горные ландшафты: пространственная организация и экологическая специфика / Аналитический обзор // Новосибирск: ПТНТБ, 2002. 83 с.

283. Черных Д.Л. Пространственно-временная организация внутриконтинентальных горных ландшафтов (на примере Русского Алтая). Дис. на соиск. степ. доктора географ. наук. - Томск, $2012,-51 \mathrm{c}$.

284. Чернышева Л. С., Чичкина Т.А., Чичкин М. П. Сравнительная характеристика динамики сумм осадков холодного и теплого периодов по некоторым станциям Приморского края // Дальний Восток России: География. Гидрометеорология. Геоэкология: материалы 6-й науч. конф. «К Всемирным дням воды и метеорологии» Владивосток, 2005. - Владивосток: Изд-во Дальневост. ун-та, 2005. - С. 202-204. 
285. Шеметова И.С. Кедрово-широколиственные леса и их гари на восточных склонах среднего Сихотэ-Алиня. - ВладивостоK, 1970. - $140 \mathrm{c}$.

286. Annual Report on Activities of the RSMC Tokyo - Typhoon Center, 2001 // JMA, 2002. http:// www.jma.go.jp/JMA_HP/jma/ jma-eng/jma-center/rsmc-hp-pub-eg/annualreport.html

287. Bisset R. Methods for environmental impact analysis: recent trends and future prospects // J. Environ. Manag. 1980. V. 11, N. 1. P. 27-43.

288. Bisset R. A Critical Survey of Methods for Environmental Impact Assessment // An Annotated Reader in Environmental Planning and Management. Oxford: Pergamon Press, 1983. P. 168-186.

289. Bastian O. Meso-scale landscape mapping and assessment // Landscape Science: theory, methods, regional studies, experience: materials of the XI International Conference. - M.: Faculty of Geography, MNU, 2006. - P. 168-170

290. Canter L. W. Environmental Impact Assessment. N. Y.: McGraw-Hill, 1977. 331 p.

291. Canter L. W. Environmental Impact Assessment. N. Y.: McGraw-Hill, 1996. 659 p.

292. Culhane P.J. The precision and accuracy of U.S. environmental impact statements // Environ. Monitoring and Assess. 1987. N. 8. P. 217-238.

293. Chudaev O. V., Chudaeva V.A., Yrchenko S.G Chemical composition of the waters at the Pav-lovsky coal quarry (Far East Russia) and surrounding areas // Regularities of the structure and evolution of the geospheres. Proceedings of VII International Interdisciplinary Scientific Sumposium and International Geoscience Programme (IGCP-467), Russia. 2005. P. 323-328.

294. Chudaeva V, Chudaev O., Sugimory K. et al. Aquatic chemistry of the Rudnaya River affected by mine tailings and prosessing plants // Chinese Journ. of Geochem. 2006. V. 25.

295. Chudaeva V.A., Chudaev O. V, Yurchenko S. G., Sugimory K., Matsuo M., KunoA. The composition of ground waters of MuraviovAmursky peninsula, Primorye, Russia // Indian J. of Marine Sciences. 2008. V 37 (2). P. 193-199.

296. Chudaeva V.A., Yurchenko S. G., Chudaev O. V. et al. Concentrations and flux of microelements to the sea of Japan from Primorye rivers // Proc. of Int. symp. «Water-Rock Interaction». 2007. V. 1. P. 493-496.
297. Furze P, Engel G. Annual Tropical Cyclone Report // U.S. Naval Pacific Meteorology and Oceanography Center / Joint Typhoon Warning Center. Pearl Harbor, Hawaii, 2003. https://metoc. npmoc. navy.mil/jtwc/atcr/2002atcr/.

298. Harrop D. O., Nixon J A. Environmental Assessment in Practice. London: Routledge, 1999. 219 p.

299. Heape M. Visual Impact Assessment // Twelfth International Seminar on Environmental Assessment and Management, University of Aberdeen, Aberdeen, Scotland, 1991. P. 133-140.

300. Goudie A. Human Impact on the Natural Environment. Oxford: Blackwell Publishers, 1997.454 p.

301. Khudyakov G I., Kulakov A. P., Nikonova R. I., Ezhov B.V. New views on morphostructure of marginal seas of Eastern Asia//J.»Phys. Earth. 1988. N 36. P. 179-189.

302. Kachur A. N., Jin X., Baklanov P. Ya., Ganzei S. S. et al. Diagnostic analysis of the Lake Khanka Basin (Peoples republic of China and Russian Federation). UNEP/CRAES/PGI FEBRAS, 2001. $136 \mathrm{p}$.

303. Nichols R., Hyman E. Evaluation of environmental assessment methods // J. Water Resour. Plan, and Manag. Div. Proc Amer. Soc. Civ. Eng. 1982. V. 108, N. 1. P. 87-105.

304. Waldichuk M. An environmental assessment and review process // Mar. Pollut. Bull. 1983. V. 14, N. 11. P. 405-408.

305. Wang H. - D., Ware J. Development of environmental quality evaluation and environmental impact assessment in China // Impact Assessment Bulletin, 1989. 8. \# 1-2. P. 145-159. 
Старожилов Валерий Титович

\title{
ЛАНДШАФТНАЯ ГЕОГРАФИЯ ПРИМОРСКОГО КРАЯ ТИХООКЕАНСКОЙ РОССИИ
}

\author{
Курс лекций \\ В трех частях \\ Часть 1 \\ Регионально-компонентная специфика \\ и пространственный анализ геосистем
}

В авторской редакции

Компьютерная верстка C.В. Филатов

Подписано в печать 12.11.2014 г.

Формат 60 х 84/16 Усл. печ. л. . Уч.-изд. л.

Тираж 500 экз. Заказ

Дальневосточный федеральный университет 690091, г. Владивосток, ул. Суханова, 8

Отпечатано в типографии

Дирекции публикационной деятельности ДВФУ 690990, г. Владивосток, ул. Пушкинская, 10 